ALESSANDRA PIMENTEL

JOGO E DESENVOLVIMENTO PROFISSIONAL:

ANÁLISE DE UMA PROPOSTA DE

FORMAÇÃO CONTINUADA DE PROFESSORES

SÃO PAULO

2004 


\section{ALESSANDRA PIMENTEL}

\section{JOGO E DESENVOLVIMENTO PROFISSIONAL: \\ ANÁLISE DE UMA PROPOSTA DE \\ FORMAÇÃO CONTINUADA DE PROFESSORES}

Tese de Doutorado apresentada à Comissão de Pós-Graduação da Faculdade de Educação da Universidade de São Paulo (FEUSP), como requisito para obtenção do título de Doutor em Educação (área de conhecimento: Psicologia e Educação), sob orientação da Profa Dra Tizuko Morchida Kishimoto e coorientação da Profa Dra Júlia OliveiraFormosinho.

\section{SÃO PAULO}


PIMENTEL, Alessandra

Jogo e Desenvolvimento Profissional: análise de uma proposta de formação continuada de professores / Alessandra Pimentel. São Paulo: USP, 2004. 225f.

Tese (Doutorado) - Faculdade de Educação da Universidade de São Paulo

Área de Conhecimento: Psicologia e Educação

Orientador: Profa. Dra. Tizuko Morchida Kishimoto

Co-orientador: Profa. Dra. Júlia Oliveira-Formosinho

1. Formação Continuada de Professores

2. Desenvolvimento Profissional

3. Educação Lúdica: jogo educativo

4. Estudo de Casos

5. Aprendizagem Experiencial 
Comissão J ulgadora:

(Profa Dra Tizuko M. Kishimoto)

(Profa Dra J ulia Oliveira-Formosinho)

(Profa Dra Yoshie U. Ferrari Leite)

(Profa Dra Wanda M. J unqueira Neves)

(Profa Dra Edda Bomtempo)

São Paulo, 19 de maio de 2005 


\section{Dedicatória}

Dedico esse trabalho aos 'fazedores de tese'...

Uma tese parece ter vida própria e expansionista. Uma das primeiras coisas que fazemos é tratá-la como uma pessoa, mas não uma pessoinha qualquer. Logo aprendemos que essa tal pessoa é caprichosa, cheia de vontades... Aprendemos a lidar com ela como uma intrusa que vem devagarinho e ganha espaço. No começo, humilde e tímida, fica circunscrita ao nosso posto de trabalho, depois ganha o sofá e, quando nos damos conta, ...já invadiu a nossa cama, disfarçada em forma de mais um livro, uma folhinha de papel, com cara de inocente pousada na nossa cabeceira...

Toda tese tem uma história, que tem páginas engraçadas, alegres, divertidas e outras que são difíceis. Aprendemos com todas elas e não são lições de consumo imediato, pelo contrário, serão incorporadas na nossa vida. No limite, nós somos o

maior objeto da tese, pois enquanto sujeito dela vivemos um embate de forças internas e externas que nos ensina muito sobre nós mesmos. Fazer a tese significa

não apenas dominar parte do conteúdo relacionado ao assunto, mas também dominar as nossas inseguranças, medos, escapes... Significa aprender a valorizar as nossas conquistas e os apoios diversos que recebemos.

(Maria Ester de Freitas, "Viver a tese é preciso") 


\section{Agradecimentos}

Aos educadores e alunos da escola que acolheu a proposta formativa, meu afetuoso agradecimento. Em especial, às professoras diretamente vinculadas ao trabalho, que tanto contribuíram para meu aprendizado.

Às auxiliares de pesquisa Julie, Mariana e Tânia, companheiras da concretização do projeto, que imprimiram sua criatividade, envolvimento e seriedade a nossas reuniões e às ações de formação.

À Tizuko, que abriu algumas portas para a expansão de meus conhecimentos.

À Júlia, co-orientadora que amavelmente ensinou-me a encontrar e construir o caminho mais pertinente entre o desejável e o possível.

À Marta, por sua sempre carinhosa atenção às minhas idéias mirabolantes, pelos conselhos, incentivos e amizade.

À Marina: sua amizade e confiança em minha capacidade foram essenciais.

À Wanda (la), por novamente fazer parte da formação de minha profissionalidade.

Um agradecimento especial ao José de Carvalho: sem seu inestimável auxílio, eu estaria escrevendo a tese até hoje!

À Valéria, pelas horas de telefonemas e e-mails que minimizaram a distância para confabularmos sobre nossas pesquisas e pelas valiosas contribuições ao texto final.

À Eliane, pela revisão competente, cuidadosa e respeitosa.

Ao Reynaldo e aos meus adorados amigos Ezelise, Felipe, Paulo, Cristine, Leila e Sérgio, pela paciência extrema e inúmeros colos.

Ao Luiz e Aurora, que amorosa e sabiamente estiveram ao meu lado em mais um passo de minha jornada profissional. Não é retórica dizer que eu não seria o que sou hoje sem vocês!

À FAPESP, pelo auxílio financeiro. 


\section{RESUMO}

O presente estudo objetiva analisar as contribuições de uma proposta de formação continuada de professores para o desenvolvimento profissional de educadoras de Ciclo I, pertencentes a uma escola pública paulistana.

A pesquisa focaliza o desenvolvimento em curso, relativo a processos ainda não internalizados na profissionalidade, mas potencializados a partir da experiência formativa.

0 projeto parte da abordagem crítico-reflexiva da profissionalidade com o objetivo de fomentar a investigação docente sobre a própria atuação pedagógica, mediante experiências de ensino com atividades lúdicas.

À luz da acepção histórico-cultural de Vygotsky, define-se jogo educativo como mediador proeminente para a aprendizagem escolar e, de maneira isomórfica, propiciador da emancipação profissional. As estratégias formativas edificam-se sob dois eixos: a) reuniões semanais com as professoras para planejamento e discussão sobre jogos e b) atividades lúdicas realizadas com os alunos.

Qualificada como estudo de casos, a investigação está centrada no percurso formativo de duas das docentes participantes, utilizando-se categorias de análise elaboradas a partir da teoria de Aprendizagem Experiencial, de David Kolb, e considerando-se o conjunto de dados advindos de três fontes - videogravações, entrevistas e diário de campo.

Os resultados apontam diferenças expressivas em relação à maneira como o projeto proporcionou às professoras refletirem sobre sua prática pedagógica e se apropriarem do referencial ludo-educativo.

A comparação dos casos evidencia que, paradoxalmente, a professora menos experiente formulou saberes da experiência mais sofisticados que sua colega - com maior tempo de carreira. Essa distinção indica que, na emancipação docente, estão implicados diferentes modos de aprender, preponderando os mecanismos de observar, indagar e resolver problemas. Também acentua que o desenvolvimento profissional é um processo multilinear e multifatorial, não sendo suficiente associá-lo a tempo de exercício profissional.

A investigação revela que a formação experiencial é profícua para implantar práticas lúdicas de ensino, favorecendo a reflexão através da troca de saberes e vivências entre professoras/formadora e entre professoras.

Embora a proposta formativa, empreendida num curto intervalo de tempo, demonstre que as professoras apreenderam conhecimentos e os incorporaram à sua prática, o nível de integração se constituiu, sobretudo, no plano aquisitivo e performático de aprendizagem. Nesse sentido, sobressaem-se as seguintes necessidades para a área de formação de professores, especialmente sob a perspectiva da ludo-educação: a) programas de formação de médio e longo prazo promoveriam a consolidação de um sistema conceitual complexo e integrado ao desenvolvimento profissional; b) a variação das estratégias formativas, bem como o apoio contínuo ao educador - desde o planejamento até a avaliação das experiências - são aspectos essenciais do trabalho do formador; c) a aprendizagem docente depende de assegurar, no contexto escolar, espaço permanente de reflexão sobre a ação pedagógica.

Palavras-chave: formação continuada de professores; desenvolvimento profissional; jogo educativo; estudo de casos; Aprendizagem Experiencial. 
The present study aims to analyze the contributions of a proposal of a continued teacher's formation for professional development of educators of $1^{\text {st }}$ Cycle, belonging to a São Paulo's public school.

The research focalizes the current development related to processes not yet internalized in the professionality, but potentialized since the formative experience.

The project is based on the critical-reflexive approach of professionality aiming to promote the academic investigation on the proper pedagogic acting, by means of teaching experiences with playful activities.

In the light of Vygotsky's historical and cultural meaning, we define the educative game as a proeminent mediator of scholar learning and in an isomorphic manner, propitiator of professional emancipation. The formative strategies are built on two axes: a weekly meetings with the teachers to plan and discuss the games; by playful activities made with students.

Qualified as study of cases, the research is centralized on the formative course of two teachers, using analysis categories elaborated since the Experiential Learning theory by David Kolb, and considering all the data deriving from 3 sources: video recordings, interviews and camp daily journal.

The results show expressive differences related to how the project provided the teacher's to think on it pedagogical practice and to the appropriation of the playful educative referential.

Comparing the cases points out that, paradoxically the less experienced teacher formulated knowledge of the experience more sophisticated than her colleague - with a longer career. This distinction indicates that, in the academic emancipation, several manners of learning are included, preponderating the observation, questioning and problem solving mechanisms. It also underlines the professional development of a multilinear and multifactorial process, not enough to relate it to a professional exercise period.

The research reveals that the experiential formation is rich to implant playful practices of teaching, benefiting thinking by means of knowledge and experiences exchanges between teachers/molder's and between teachers.

Although the formative proposal, made in a short time, shows that teachers seized knowledge and incorporated it to their practice, the integration level is constituted, mainly, on the acquisition and performatic plans of learning. Thus, the following needs stand out for the teachers' formation area, especially under the playful educational perspective: (a) short or medium term formation programs promotes the consolidation of a complex conceptual system integrated to professional development; (b) formative strategy variations, as well as continuous support to educator since planning until experience evaluation - are essential aspects of the molder's work; (c) the teacher's learning academic apprentice ship depends on the assurance, in the scholar context, of a permanent space of reflection on the pedagogic action.

Keywords: teachers' continued formation, professional development; educational games; study of cases; Experiential Learning. 


\section{RÈSUMÈ}

La présente investigation vise a analyser les contributions d'une proposition de formation continue de professeurs pour le dévéloppement professionnel des educateurs du 1er Cycle, appartenants a une école publique de São Paulo.

La recherche focalise le dévéloppement en cours, relatif aux processus pas encore incorporés dans la professionnalité, mais potentialisés a partir d'une experience formative.

Le procês part de l'abordage critico-reflexif de la professionnalité avec l'objectif de fomenter l'investigation sur la propre action pédagogique atravêrs des experiences d'enseignement avec des activités ludiques.

D'aprês l'acceptation historique-culturelle de Vygotsky, le jeu educatif se défini comme le mediateur proéminant pour l'apprentissage scolare e, d'une maniêre isomorphique propicie l'emancipation professionnelle. Les strategies formatives sont édifiées sous deux angles: (a) reunions hebdomadaires avec les professeurs pour programmer et discuter les jeux et (b) les activités ludique realisées avec les êléves.

Qualifiée comme une etude de cas, l'investigation est centrée sur le parcours formatif de deux des professeurs participants en utilisant des analyses elaborées a partir de la Theorie de l'Apprentissage Experientiel de David Kolb, e considerant l'ensemble de données derivant de 3 sources: les videosgravations, les entrevues e l'agenda journalier de champs.

Les resultats montrent des differences expressives sur la maniére comme le projet a permi aux professeurs de reflechir sur la pratique pedagogique e de s'approprier du référentiel ludo-educatif.

La comparaison des cas evidencie que, paradoxalement, le professeur avec le moins d'experience a formulé un savoir plus sophistiqué que sa collégue - avect plus de temps de carriére. Cette distinction indique que, dans l'emancipation professionnel, differents modes d'enseignement sont impliqués, avec prepondérance pour les mecanismes d'observation, de recherches et de resolution des problêmes. Aussi elle rehausse le fait que le dévéloppement professionnel est un procês multilineair e multifactoriel, n'etant pas suffisant de l'associer a la durée de l'exercice professionnel.

L'investigation montre que la formation "experiencelle" est avantageuse pour I' implantation d'activités ludique de l'enseignement, facilitant la reflexion atravêrs l'echange de savoir et d'experiences entre les professeurs/preparateur et entre les professeurs.

Bien que la proposition formative, entreprise dans un court lapse de temps, demontre que les professeurs saisirent le savoir et l'incorporérent á leur pratique, le niveau d'intêgration s'est constitué, surtout, sur le plan acquisitif e éxécutif de l'apprentissage. Dans ce sens, les necessités suivantes sont rehaussées dans le domaine de formation de professeurs, especialement sous une perspective ludo-educative: (a) programme de formation a mi et long terme pourrait promouvoir la consolidation d'un systême conceptuel complexe et intégré au dévéloppement professionnel; (b) la variation des strategies formatives - â partir de la programmation jusqu'â l'evaluation des experiences - sont des aspects essentiels du travail du preparateur; (c) l'apprentissage de les educateurs dépend de l'assurance, dans le contexte scolaire d'un espace permanent de reflexion sur l'action pedagogique.

Mots-clefs: formation continue de professeurs; dévéloppement professionnel; jeu educatif; etude de cas; Theorie de l'Apprentissage Experientiel. 
INTRODUÇÃO

1 - FORMAÇÃO CONTI NUADA DE PROFESSORES: TESSI TURAS DO

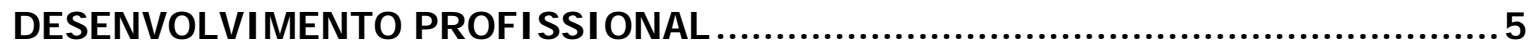

1.1 - Formação de Professores: a caminho da Formação em Contexto...................... 7

1.2 - Perspectivas do Desenvolvimento Profissional ..................................... 17

2 - EDUCAÇÃO LÚDI CA NA FORMAÇÃO E NA PRÁTI CA DOCENTE....................25

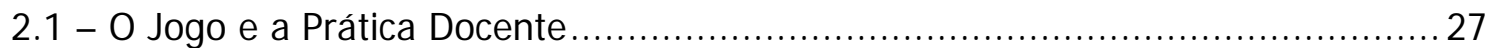

2.2 - Abordagem vygotskiana para a formação lúdica de professores ...................... 35

2.3 - Princípios da ludo-educação ............................................................ 43

2.4 - Educação Lúdica no Ensino Fundamental .............................................. 49

3 - ENFOQUE TEÓRI CO DA ANÁLI SE DO PROJ ETO FORMATI VO.......................58

3.1 - Aprendizagem Experiencial - Conceituação ............................................. 59

3.2 - Aprendizagem Experimental - Características......................................... 64

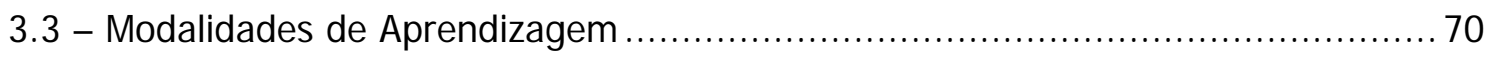

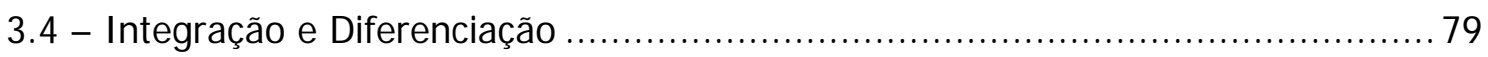

4 - ENFOQUE METODOLÓGI CO DO PROCESSO FORMATI VO..........................86

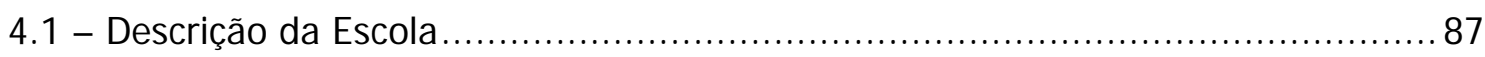

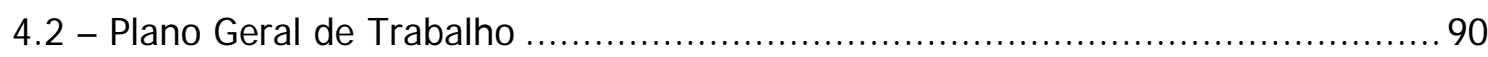

4.3 - Criatividade como Princípio Metodológico............................................ 93

4.4 - Instrumentos de Coleta de Dados ............................................... 97

4.5 - Procedimentos de Análise para o Estudo de Casos .................................... 99

5 - ANÁLI SE DO DESENVOLVI MENTO PROFISSI ONAL..................................119

5.1 - DESCRIÇÃO ANÁLISE DO PROJ ETO DE FORMAÇÃO …........................... 119

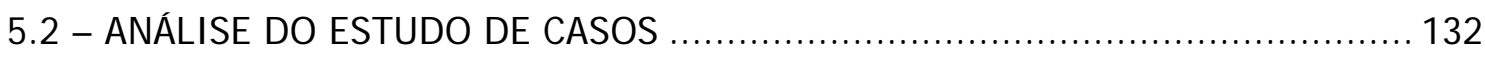

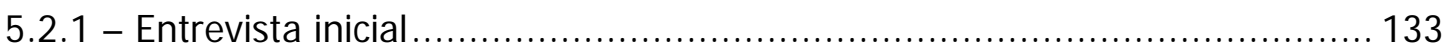

5.2 .2 - Primeiros contatos com o corpo discente ..................................... 138

5.2.3 - O Percurso Formativo e o Desenvolvimento Profissional Docente ............. 141

5.2 .4 - Entrevistas final e de feedback................................................. 191

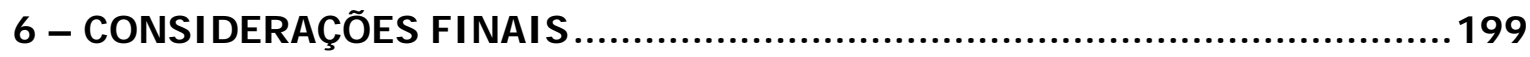

7 - REFERÊNCI AS BI BLIOGRÁFI CAS ......................................................... 209

ANEXOS 


\section{LISTA DE QUADROS}

Quadro 1.1 - Dicotomias no Desenvolvimento Profissional dos Professores 13

Quadro 3.1 - Teoria da Aprendizagem Experiencial do Desenvolvimento - níveis de adaptação e de estrutura da consciência 85

Quadro 4.1 - Participantes do Projeto Formativo 89

Quadro 4.2 - Temas e categorias dos encontros formativos 114

Quadro 4.3 - Temas e categorias de situações ludo-educativas com os alunos 118

Quadro 5.1 - Estratégias formativas.

Quadro 5.2 - Primeira Fase do Projeto Formativo 122

Quadro 5.3 - Segunda Fase do Projeto Formativo 125

Quadro 5.4 - Terceira fase do projeto formativo 128

Quadro 5.5 - Quarta fase do projeto formativo 130 


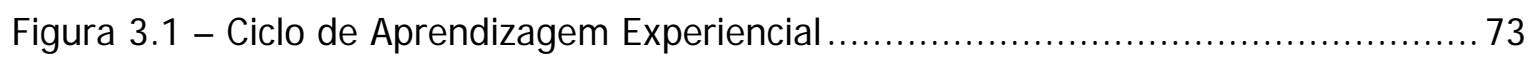

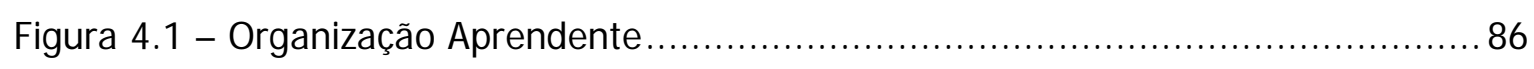

Figura 4.2 - Ciclo de vinculação entre imaginação e educação lúdica ............................94

Figura 4.3 - Diagrama Descritivo da Análise do Projeto Formativo e do Estudo de

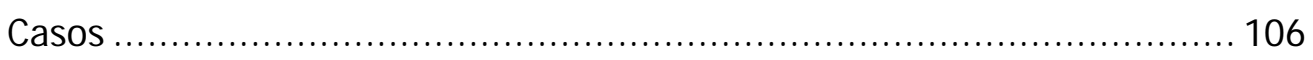

Figura 5.1 - Representação de atividade observada na classe de Lia .......................... 139 


\section{NTRODUÇÃO}

0 presente estudo fundamenta-se na existência de uma relação entre jogo $^{1}$ e desenvolvimento profissional de professores. Creditamos ao jogo um grande potencial a ser explorado pela educação escolar. Na vida cotidiana, especialmente da criança, são inumeráveis as situações em que o jogo incita o desejo de aprender, impõe a necessidade de resolver problemas e viabiliza o autoconhecimento, não porque seja imposto, exatamente pelo contrário. Os educadores - por sua experiência pessoal, pela observação de crianças brincando no dia-a-dia, ou mesmo por deixarem seus alunos brincando por algum tempo reconhecem o valor dessa atividade. Alguns a consideram uma necessidade no desenvolvimento infantil; outros, um potencial para a educação.

Ainda há muito a ser compreendido acerca das potencialidades da atividade lúdica, sobretudo nos níveis de ensino posteriores à Educação Infantil (nível em que é mais freqüente a criança desfrutar de brincadeiras e jogos).

Inversamente, no Ensino Fundamental - nível em que centramos nossa atenção e temos insistido em tornar factível a educação lúdica ${ }^{2}$ - o primeiro contato da criança é quase sempre desprovido de qualquer atividade que permita, até mesmo, o movimento entre as carteiras enfileiradas. Os professores das séries iniciais precisam cumprir o programa curricular acentuadamente disciplinarizado e conteudista. Em geral, lidam com classes numerosas, condições precárias de trabalho e obrigações burocráticas. A brincadeira parece ser incompatível com esse cenário, repleto de dever e sujeição. No entanto, entre os professores, é praticamente unânime a crença de que existe algo de valor no jogo para 0 seu ofício.

\section{J ustificativa}

A gênese do presente estudo reporta-se a experiências na área de formação de professores empreendidas a partir de 1998, época em que integrávamos o corpo docente do curso de Psicologia da Universidade Estadual de Londrina (UEL, Paraná).

Durante os dois anos de coordenação do projeto de extensão universitária, "Ludoteca vai

1 Jogo, brinquedo e brincadeira serão utilizados com o significado geral de ato ou atividade lúdica, sendo preferencialmente empregada a palavra jogo. Maior aprofundamento conceitual encontra-se na obra Kishimoto, T. M. (1998). O jogo e a educação infantil. São Paulo: Pioneira.

2 Termo cunhado por Paulo de Almeida (1998), designando um modelo educacional em que a ludicidade norteia decisões e ações de caráter pedagógico. No Brasil, seu emprego é comum (como faz Rabelo, 1998), com a mesma significação de ludo-educação - terminologia encontrada na literatura internacional, como é o caso de Selma Wassermann (1990), pesquisadora canadense, uma das referências para elaborarmos nosso posicionamento. No presente estudo, educação lúdica e ludo-educação são sinônimos. 
às escolas"3 , assumimos desde sua elaboração até sua avaliação, contando com uma equipe de estagiárias do terceiro e quinto anos do curso de Psicologia que, conosco, desempenharam ações em diversas escolas e creches da rede de ensino público, em Londrina e cidades circunvizinhas.

O 'Ludoteca', num de seus desdobramentos, dirigiu-se a professores das quatro séries iniciais do Ensino Fundamental. No formato em que o propusemos, foi executado por meio de ciclos de Oficinas Lúdicas, com o propósito de viabilizar o uso educativo de jogos e brincadeiras no ensino.

No transcorrer da execução do projeto, inclusive por seu caráter demasiado pragmático, passamos a observar uma série de dificuldades na incorporação do jogo à prática dos professores - notadamente a dependência de nossas indicações e orientações. ${ }^{4}$

O 'Ludoteca' foi a primeira experiência em que formação de professores e jogo foram a temática central. Contudo, a cada novo mergulho nesse campo de atuação, ora na docência para a formação inicial numa faculdade particular paulistana ora em cursos de curta duração, um misto de prazer/incômodo tornou-se constante.

Prazer não apenas porque experienciamos com os participantes as mesmas descobertas e sensações na confecção de brinquedos, uso de jogos e debate sobre as vivências lúdicas, mas também porque houve envolvimento, legitimando a colaboração e o respeito à opinião divergente, facilitando a troca de idéias e operando mudanças em nós. Incômodo porque, ao se fecharem as cortinas, os professores se dirigiam ao seu local de trabalho, às carteiras e quadro-negro postos nos 'devidos lugares', aos alunos que não brincam.

Será que, ao retornarem à sua prática profissional - ou iniciarem a carreira - os docentes conseguiriam ter autonomia para formular, juntamente com seus alunos, uma nova maneira de desenvolver o processo de ensino-aprendizagem? A mediação do professor poderia ser feita através de jogos, ao invés de cópias e exercícios mimeografados? Haveria mesmo possibilidade de transformar a prática pedagógica por meio de jogos educativos?

Para responder essas questões, elaboramos um projeto de formação continuada de professores, fundamentada no princípio de que o jogo propicia o desenvolvimento humano, para a criança e para o adulto. Não se trata de propor que o educador brinque, mas que aprofunde seu conhecimento sobre a brincadeira - modificando sua atuação profissional e se modificando - e que desenvolva maneiras diversas de avaliar a aprendizagem, instigar à

\footnotetext{
${ }^{3}$ Esse projeto integrou o Programa de Extensão Comunitária "Ludoteca-UEL", criado em 1990, e composto por uma equipe interdisciplinar de professores efetivos dos cursos de Psicologia, Arte, Educação Física, Matemática, Biblioteconomia e Pedagogia da Universidade Estadual de Londrina (PR).

4 Situação semelhante é constatada pelos estudos de Brougère (1998), Uemura (1988), Wajshop (1996), França (1990), dentre outros, em que depoimentos de professores apontam insegurança para fazer uso de jogo educativo, justificada por falta de preparo ou por crença em sua incompatibilidade com o ensino.
} 
resolução de problemas, orientar e auxiliar os alunos na elaboração de hipóteses e organizar o cenário de aprendizagem para que investiguem sua própria trajetória de desenvolvimento e de produção de conhecimento.

Assim, para promover um processo reflexivo dos profissionais acerca da ludo-educação, tornou-se imperativo assumirmos uma proposta destinada à apropriação do sentido mais relevante da relação entre educação e jogo - não meramente como roupagem 'mais agradável' para lidar com os conteúdos pedagógicos, mas como algo essencial ao desenvolvimento humano, em particular, das habilidades e competências cognitivas e sócioafetivas que alicerçam transformações na atuação pedagógica.

\section{Objetivo}

A presente pesquisa qualifica-se como um estudo de casos cuja finalidade é examinar em que medida um projeto de formação continuada de professores, centrado numa abordagem lúdica de educação, contribuiu para o desenvolvimento profissional de professoras de $1^{\mathrm{a}}$ a $4^{\mathrm{a}}$ série do Ensino Fundamental.

O foco central da análise é o início de um processo de transformação reflexiva da prática pedagógica, são os primeiros ensaios de mudança e as elaborações inconclusas, ou seja, os primórdios de um saber-fazer ludo-educativo, circunscrito pelo nível potencial de desenvolvimento profissional.

Almejando identificar os saberes ludo-educativos emergentes, esquadrinhamos 0 percurso de formação de duas das nove docentes participantes, escolhidas para o estudo de casos mediante a hipótese de que houve distinções importantes na maneira como a proposta ludo-educativa de formação repercutiu no desenvolvimento profissional de cada uma delas.

A proposta de formação continuada de professores seguiu a orientação crítico-reflexiva de profissionalidade docente e se delineou como uma experiência de ensino lúdico, ou seja, uma formação centrada na práxis da 'ludo-educação', visando a um saber-fazer reflexivo, em que 0 jogo se constitua um mediador relevante para o Ensino Fundamental, em particular, para o Ciclo I ( $1^{\text {a }}$ a $4^{\text {a }}$ série).

O projeto foi estruturado com base na homologia entre os processos de aprendizagem docente e discente, ou seja, procurou se dimensionar pelo isomorfismo entre a formação de professores e sua atuação. Desse modo, o jogo se inseriu na formação como instrumento de planejamento, realização e avaliação de práticas lúdicas vinculadas aos objetivos escolares.

Realizada durante oito meses do ano de 2002, junto a professoras ${ }^{5}$ pertencentes a uma

5 o gênero feminino desse substantivo remete ao corpo de profissionais diretamente envolvidos no projeto. Utilizamos o masculino somente quando nos referimos à formação docente em geral. 
escola pública paulistana, a proposta baseou-se nos seguintes objetivos específicos:

$\leftrightarrow$ sensibilizar as professoras quanto à relevância das atividades de caráter lúdico nos processos de aprendizagem e de desenvolvimento do educando;

$\stackrel{4}{*}$ propiciar espaço de investigação reflexiva sobre o saber-fazer;

$\stackrel{\leftrightarrow}{4}$ contribuir para o desenvolvimento de competências teórico-metodológicas relativas à educação lúdica;

$\Leftrightarrow$ potencializar a construção de um sistema de conhecimento, integrado e pessoal, sobre a educação lúdica (ludo-educação).

A abordagem sobre o jogo foi delineada à luz da acepção histórico-cultural, que também definiu nossa atuação como formadora. A partir do ponto de vista vygotskiano, consideramos que o jogo educativo possibilita ao educador ampliar, aprofundar e tornar melhor o processo educativo dos alunos. Por seu turno, a formação sobre e para a prática ludo-educativa: a) destina-se à criação de zonas de desenvolvimento proximal, propiciadas na e pela interação, tanto com o formador quanto com os pares; b) aborda a profissionalidade nos planos interpsicológico e intrapsicológico; c) releva tanto os saberes da prática constituídos quanto os que estão se constituindo; d) caracteriza formador e estratégias formativas como mediadores no processo de desenvolvimento.

Neste estudo, jogo é entendido como atividade ludo-educativa, alinhavada com o currículo de Ensino Fundamental. É postulado como mediador do processo de ensinoaprendizagem e, conforme as diretrizes vygotskianas, é composto por um rol de regras (definidas a priori ou não) e provido de processos imaginários.

A reflexão, núcleo da formação e do desenvolvimento profissional docente, constitui-se de diferentes níveis - desde o mais direto, como componente permanente da ação educativa, até os que envolvem o plano escolar e as interações dos profissionais que nele atuam; o entorno à escola junto à comunidade e familiares da clientela; o sistema educacional, presentificado por órgãos que acompanham o trabalho educativo e por normas que 0 regimentam.

A formação continuada de professores deve ser um processo contínuo de reflexão autônoma, substantivando suas decisões sobre saberes, valores pessoais e conhecimentos teórico-práticos que os tornem capazes de avaliar o desenvolvimento das competências que fazem parte de sua própria profissionalidade.

A formação para a prática lúdica de ensino visa atender às necessidades formativas do educador e do contexto escolar; portanto, unir a teoria à prática, dialeticamente. 


\section{1 - FORMAÇÃO CONTI NUADA DE PROFESSORES: TESSI TURAS DO DESENVOLVI MENTO PROFI SSI ONAL}

Nas últimas décadas, investigações e programas na área de formação de professores pleiteiam mudança no cenário das escolas.

Um novo perfil de professor se constitui na educação brasileira, cuja tônica na valorização das competências é fator de grande mobilização, seja no terreno legislativo, nas reformas implantadas em alguns sistemas educacionais das redes estaduais e municipais, ou nas experiências esparsas em escolas públicas e particulares.

A academia, também mobilizada, torna-se pólo de investigação e elaboração de programas de formação. Géglio (1999) observa que, no conjunto de teses e dissertações produzidas a partir da metade da década de 80, a formação docente torna-se objeto de estudo e questionamento para diversos autores da área de educação e que, desde o final dos anos 80, a vertente crítico-reflexiva ganha grande destaque, com enfoque em teóricos como Schön, Sacristán, Zeichner, entre outros.

Os desafios postos à formação de professores têm sido fervorosamente debatidos e estudados, num esforço coletivo dos profissionais de educação em assumir o compromisso de promover as mudanças em prol da melhoria do ensino, particularmente aquelas vinculadas à profissionalidade docente.

A exigência de novos papéis para o professor, de novas práticas de formação de professores - e de uma nova escola - encontram-se e inter-relacionam-se no discurso de modernização do Estado para produzir um tipo de homem que possa contribuir para (servir) os avanços de uma sociedade tecnológica que, cada vez mais, passa a exigir modelos de ensino que valorizem o pensamento crítico e reflexivo; produzam cidadãos autônomos, independentes, decididos e que saibam resolver problemas, requisitos considerados fundamentais pela lógica produtiva e que vêm afetando o trabalho do professor (Nunes, 2000: 21).

Discussões teóricas, pesquisas empíricas e mudanças na legislação revelam que ao professor não é suficiente deter, gerenciar e colocar à disposição dos alunos os conhecimentos socialmente construídos. É preciso escolher meios de ensino adequados e motivadores, garantindo o posicionamento ativo do aluno na apropriação de conhecimentos, resultante de "um complexo e intrincado processo de construção, modificação e reorganização utilizado" (Brasil, 1998: 72) para interpretar e dar significado aos conteúdos escolares.

Grande parte dos problemas educacionais - por vezes, reduzidos a classificações genéricas de comportamento desajustado e/ou dificuldade de aprendizagem - revela um ambiente escolar, se não apático, hostil, em que a repetição quase automatizada distancia o 
aluno de seu próprio cotidiano, tornando a sala de aula um lugar insípido, que não favorece a aprendizagem.

Não existem conteúdos mais ou menos interessantes; entretanto, há formas diferentes de acessá-los e (re)construí-los, interferindo diretamente no envolvimento dos alunos com o aprender. A opção do professor por uma determinada metodologia não é aleatória, presentifica suas concepções e princípios educativos, podendo aproximá-lo ou afastá-lo do que denominamos de Educação Lúdica - acepção que prioriza o desejo de aprender do aluno, partindo de suas necessidades e interesses (Almeida, 1998) e que encontra ressonância no que dispõe a nova Lei de Diretrizes e Bases, promulgada em 1996, conforme análise de Demo (1997: 88):

\section{A aula já não pode ser tomada como didática central; o mais importante são ambientes instigadores de aprendizagem que façam convergir a presença exemplar de um professor capaz de reconstruir conhecimento com o esforço reconstrutivo permanente dos alunos.}

Aprendizagem mediada pelo brincar apresenta a possibilidade de reaver a educação com significado para professores e educandos, ao contrário da visão dicotômica dos espaços lúdico e educativo, que sugere incompatíveis a seriedade e compenetração do processo de ensino com a satisfação pessoal e o prazer encontrados no brinquedo e na brincadeira.

Por intermédio da relação jogo-educação objetivamos contribuir para abortar o ciclo vicioso que domina a escola, sujeitando-a a uma mesmice desmotivadora.

A formação continuada é concomitante ao exercício profissional, pós-escolar, implicando aquisição de conhecimentos, atitudes e competências. A atuação docente adquire o valor de principal elemento de análise e reflexão, e o professor assume "uma dimensão participativa, flexível e ativa/investigadora" (Garcia, 1992: 54).

Salientando "a prática como fonte de conhecimento através da experimentação e reflexão (diálogo com a própria ação) e da discussão" (Scarpa, 1998: 40), propusemos o trabalho em grupo - visando à construção de um espaço interativo do corpo docente para troca de experiências, colaboração, confronto de idéias, busca conjunta de vias de ação, enfim, mediação entre pares, contribuindo para a elaboração pessoal que, por sua vez, decorre do desafio "de transformar em ensino o conteúdo aprendido durante... o percurso formativo" (Garcia, 1992: 57).

Assim, configuramos o eixo do projeto de formação como dinâmica coletiva de construção de conhecimentos, tendo como referência o conceito de professor reflexivo. Refletir significa tomar continuamente a própria prática como objeto de análise, identificando necessidades e formulando criticamente soluções que, postas em ação, geram um movimento contínuo entre ação-reflexão-ação (Schön, 1992; Pérez Gómez, 1992, Pimenta, 
2000). ${ }^{6}$

Considerando que a formação continuada "passa pela experimentação, pela inovação, pelo ensaio de novos modos de trabalho pedagógico" (Nóvoa, 1992: 28), visamos a um processo autônomo e dinâmico de reflexão sobre/na ação pedagógica com o redimensionamento dos cenários de aprendizagem (Wertsch, Del Rio e Alvarez, 1995), relativos à organização do ambiente escolar, sobretudo da sala de aula, para instaurar um clima de interesse, participação e aprendizagem efetiva.

É indispensável reconhecer que os professores possuem 'teorias implícitas' sobre o ensino - saberes experimentalmente construídos, originários da prática cotidiana, que influenciam o pensar e o agir. Saberes vitais à reflexão, entendida como ato metacognitivo, ou seja, ao mesmo tempo voluntário e consciente, por meio do qual se instaura um distanciamento da prática que permita analisá-la, implicando um aprender fazendo (Schön, 1992).

Do mesmo modo, há conhecimentos prévios sobre o jogo, formulados pela experiência pessoal e história de vida. Tais saberes não podem ser ignorados; ao contrário, indicam o princípio de nosso trabalho para gerar um corpus teórico fundamentado pelo encontro entre o que já conhecem e o que necessitam saber para a prática lúdica de ensino.

\section{1 - Formação de Professores: a caminho da Formação em Contexto}

Dos anos 40 aos 70, a formação de professores tinha acentuado caráter de treinamento ou de aperfeiçoamento, tanto em relação às diretrizes e currículos de formação inicial quanto à formação pós-escolar (as denominações "continuada" ou "contínua" são posteriores ao período). A partir do final da década de 70 , desenvolvem-se diversas modalidades de formação que pretendem dar conta da complexidade do tema.

O cuidado com a formação dos educadores decorreu de uma constatação histórica: uma série de linhas de ação, cada qual seguindo uma vertente teórica, foram planejadas e postas em prática, sem se obter sucesso para remediar os graves problemas de ensino existentes no país desde o início do século XX.

Na chegada da segunda metade do século XX, a educação é tema de grande relevo. Reavivando-se os princípios do escolanovismo do início da República [Antunes, 1991], é tida como o mais poderoso instrumento para a reconstrução e melhoria da sociedade brasileira. Diferentemente do que havia predominado até então, o indivíduo passa a ser visto como resultante de múltiplas influências do ambiente social. Essa visão, largamente repercutida nos programas de educação compensatória,

\footnotetext{
${ }^{6}$ Compartilhando do mesmo posicionamento, outros autores formularam os conceitos de profissional autônomo (Nóvoa, 1992) e de professor-pesquisador, empregado por Elliott (2000); Geraldi, Messias, Guerra (2000) e Zeichner (2000)
} 
reflete $o$ peso das abordagens psicológicas ambientalistas do desenvolvimento infantil que fundamentaram modelos educacionais das décadas subseqüentes.

...Em conformidade com a política desenvolvimentista, passou-se a defender a tese da garantia e expansão das oportunidades de acesso à educação, com a finalidade de diminuir os índices de analfabetismo, que se contrapunham e fragilizavam o projeto de desenvolvimento econômico auspiciado.

... Reproduzindo as diretrizes político-econômicas e a estrutura social do Brasil, eram inumeráveis as pesquisas estatísticas sobre evasão e repetência encomendadas pelos órgãos públicos. Nelas, o problema do analfabetismo era equacionado em termos de índice de desperdício, concluindo-se que o país gastava montante incomensurável com educação sem haver, contudo, um retorno para a sociedade, ou seja, produtos condizentes com os gastos. Esse índice justificava as medidas de intervenção, particularmente por meio da implantação de programas de educação compensatória e de treinamento.

...A fim de minimizar a baixa qualidade de ensino, os programas de treinamento [anos quarenta a sessenta] e de aperfeiçoamento [década de setenta] eram planejados e executados por órgãos governamentais, quase na sua totalidade. Caracterizavam-se por suplências em cursos, workshops, ciclos de conferências com as mais diferentes abordagens e estratégias, visando acima de tudo suplantar as lacunas e deficiências da formação inicial. (Pimentel, 1997: p.20-24, grifos da autora)

Os baixos resultados desses programas suscitaram questionamentos sobre como era definida e abordada a formação de professores.

A partir de meados dos anos 80, os modelos formativos passam a enfatizar o respeito aos saberes e competências dos professores para não comprometer a qualidade dos programas destinados à formação. Os conhecimentos dos professores e sua maneira de interpretar a pedagogia na sala de aula são imprescindíveis para o sucesso de um programa de formação. Segundo Poppovic (1983 apud Pimentel, 1997) - uma das primeiras vozes a debater sobre o assunto no Brasil - é sobretudo pela influência das posições 'sóciointeracionistas' de Bruner, Piaget e Vygotsky que se alicerça esta nova maneira de compreender e tratar a formação de professores.

Os conceitos de professor reflexivo, profissional reflexivo, prática reflexiva surgem como reação ao fato de os professores terem sido considerados meros tarefeiros, ou seja, cumpridores de propostas e ações pensadas e determinadas por agentes distantes, senão estranhos, ao cotidiano e às condições reais do ensino nas salas de aula das escolas. Todo um movimento se faz no sentido de reconhecer e devolver ao professor o status que lhe é intrínseco: ser sujeito de sua própria profissão. Do ponto de vista histórico, um conjunto de fatores - tais como centralização e controle do poder político, representações dos docentes 
como sacerdotes, feminização do magistério, valorização excessiva de conhecimentos teóricos das Ciências da Educação e ausência de espaços institucionais para favorecer a reflexão partilhada - determinaram desvalorização social e científica dos saberes constituídos na prática reflexiva dos professores (Nóvoa, 1992).

A polêmica acerca da definição do professor como sujeito de reflexão é inexorável ao campo da formação. Não há unanimidade em torno do que seja a reflexão pedagógica e seus fins. O embate não é travado apenas em relação aos aspectos formais da caracterização; pelo contrário, as discussões se desdobram em torno do que instaurar, estimular e manter o processo reflexivo.

Segundo Kemmis (apud Pérez Gómez, 1992: 103), refletir é um processo orientado para a ação na medida em que supõe e prefigura relações sociais, e não uma forma individualista de trabalho mental. Por isso, a prática reflexiva nunca se dá com plena isenção de valores, mas exprime e serve a interesses humanos, políticos, culturais e sociais. Assim entendida, a reflexão não é um processo passivo, um simples exercício mecânico de identificação ou discriminação de variáveis, tampouco um exercício de criação de idéias isoladas. É uma prática que exprime um poder de (re)construir a vida social.

Vista por esse ângulo, a reflexão não se reduz unicamente a processos psicológicos no indivíduo, mas

implica a imersão consciente do homem no mundo da sua experiência, um mundo carregado de conotações, valores, intercâmbios simbólicos, correspondências afetivas, interesses sociais e cenários políticos. (ibid.)

A reflexão é orientada pela e para a prática, deriva do saber-fazer constituído, visando modificá-lo. 0 educador constantemente reelabora sua prática reflexiva "pela reflexão-sobrea-ação, isto é, pela reflexão empreendida antes, durante e depois da sua atuação, tendo em vista a superação das dificuldades experienciadas no cotidiano escolar (Pimenta, 1999: 4).

Nuclear à formação do educador, a reflexão é

o aspecto que Ihe garante autonomia e apropriação do seu saber, pois é na ação reflexiva que somos levados a constatações, descobertas, reparos, aprofundamentos, ou seja, somos levados a transformar algo em nós, nos outros, na realidade. (Zibetti, 1999: 63)

Em sintonia com a modalidade reflexiva de formação, a construção do saber-fazer é um processo pessoal, construído coletiva e institucionalmente no interior da profissionalidade docente.

A formação é centrada no contexto de trabalho, sem significar que esteja limitada ao espaço físico escolar. O contexto é referência à pesquisa, derivada do contínuo contato com as práticas exercidas no cotidiano escolar investigado. Pesquisa e prática são necessárias ao 
surgimento e à manutenção da emancipação investigativa dos sujeitos que protagonizam a ação educativa.

Profissionalidade docente diz respeito a todos os fatores envolvidos no saber-fazer do educador. Na construção de saberes da prática lado a lado à reflexão...

desvela a necessidade, como nos diz Kincheloe (1997: 1960), 'de pensar sobre nosso pensar, porque nós exploramos nossa própria construção da consciência, nossa autoprodução', mas, principalmente, necessidade de compartilhar nossos pensamentos para engajar-nos a uma prática pedagógica mais efetiva, mais educativa. (Pimenta, 2000: 77)

O conceito de profissionalidade reflete os frutos do desenvolvimento profissional e toma forma na ação educativa. Constitui-se de competências, conhecimentos, sentimentos e posicionamento moral relativos à profissão. O desenvolvimento da profissionalidade sofre influência do contexto de trabalho, caracterizado por mecanismos sociais de poder, emolduramentos curriculares e normativos, políticas educacionais e gerenciamento escolar. Nesta configuração também estão implicados os princípios e modelos de educação que regem as diretrizes de ensino do contexto escolar específico. Desse modo, uma compreensão holística da profissionalidade se fundamenta não apenas nas características definidoras do perfil docente, mas também na relação com as vicissitudes do contexto educativo que faz parte da história pessoal do educador.

A profissionalidade docente é um conceito dinâmico. Implica um crescimento multilinear em especificidade, racionalidade e eficácia dos saberes ligados à atividade profissional (Oliveira-Formosinho \& Formosinho, 2001). Esses saberes sobre/na ação referem-se a modos de pensar evidenciados na ação prática. Representam concepções do educador sobre desenvolvimento e aprendizagem. Emolduram as interações com os colegas; seleção, transformação, organização e relação de conhecimentos em conteúdos escolares; planejamento e rotina de gestão de aula; competências e estratégias para lidar com imprevistos; conjunto de atitudes, crenças e valores presentes na interação com os alunos.

Em síntese, os saberes da profissionalidade regem a atuação em termos de:

a) planejamento dos conteúdos de ensino,

b) procedimentos pedagógicos,

c) organização do cenário de aprendizagem,

d) preparo de recursos pedagógicos,

e) uso de estratégias interativas.

Por sua vez, as condições contextuais exercem profunda influência para o professor se apropriar autonomamente de sua profissionalidade e desenvolver projetos pensados coletivamente no espaço escolar. Ao contrário da fragmentação disciplinar e do isolamento, a 
autonomia desenvolvida pela interação entre pares decorre do pensar reflexivamente sobre a atuação profissional, ou seja, de um processo metacognitivo bidimensional: saber fazer e reconhecer que sabe. Como afirma Almeida (1999), a consciência autônoma sobre o ser docente está baseada num tríplice desenvolvimento referente ao contexto de atuação: pessoal, profissional e organizacional.

Transformações qualitativamente positivas na atuação docente requerem investimento num processo emancipatório do educador (Zeichner, 1992; Kincheloe, 1997), em que o desenvolvimento da consciência autônoma é determinante/determinado pela reflexão na ação (Schön, 1992).

A prática reflexiva consiste no compromisso a favor da reflexão enquanto prática social... Este compromisso tem um importante valor estratégico para criar as condições que permitam trocas entre instituição escolar $e$ meio social. (Zeichner, 1992: 49)

A atitude reflexiva não depende apenas das condições formativas, mas também das disposições objetivas de organização do trabalho, sobretudo porque solidificada pelas parcerias, discordâncias, trocas de experiência, confrontos de idéias destinados ao exame e aprimoramento conceitual sobre o ensino-aprendizado. Como referenda Paulo Freire, dentre os seres 'inconclusos', o homem é o único "capaz de ter, não apenas sua própria atividade, mas a si mesmo como objeto de sua consciência, o que o distingue do animal, incapaz de separar-se de sua atividade" (1975:104).

O comportamento autônomo não aparece 'naturalmente'. Depende da investigação permanente sobre a própria prática. É desenvolvido/exercido num contexto a várias vozes (Formosinho e Machado, 2000). Portanto, esta investigação autônoma e reflexiva é instrumento fundamental tanto para definir ações educativas quanto formativas, visando ao desenvolvimento profissional.

Assim, o desenvolvimento dos saberes constituintes da profissionalidade docente estão circunscritos pela dinâmica contextual do local de trabalho, que deve se configurar como espaço legítimo para o desenvolvimento profissional docente, em sintonia contínua com a dinâmica interpessoal de trabalho - considerando as relações entre instituição e outras esferas (regulamentações do ensino, órgãos do sistema educativo, âmbito familiar dos educandos e comunidade externa).

Zeichner (2000: 227) entende a articulação entre profissionalidade e âmbito institucional como respaldo da reflexão docente, num processo emancipatório que objetiva "educar professores para serem pensadores autônomos e práticos reflexivos e para que estejam comprometidos com a educação de alta qualidade para todos os estudantes".

De acordo com a abordagem de formação em contexto (Oliveira-Formosinho \& 
Formosinho, 2001) $)^{7}$ a emancipação docente está na relação entre o profissional e o contexto de que faz parte e em que atua.

Os contextos vivenciais constituem uma rede entrelaçada de tempos, espaços, crenças, normas e encontros afetivos, não se referindo somente à sala de aula ou às interações profissionais. No interior da escola, são diversos os fatores que, imbricados, afetam o processo de desenvolvimento profissional, dentre os quais: condições de apoio institucional e interpessoal; disponibilidade dos recursos; condições para planificação; interações cooperativas; mecanismos de poder explícitos e implícitos. Neste sentido, faz-se necessário garantir o isomorfismo entre professores e alunos quanto às condições positivas (apoio e reconhecimento) para a auto-estima e o autoconceito, aspectos decisivos para a cultura profissional colaborativa.

Nas palavras de Oliveira-Formosinho e Formosinho (2001), a Formação em Contexto referenda-se no modelo ecológico de desenvolvimento humano, elaborado por Bronfenbrenner, podendo ser projetada para uma abordagem de formação continuada de professores em que implica estudar...

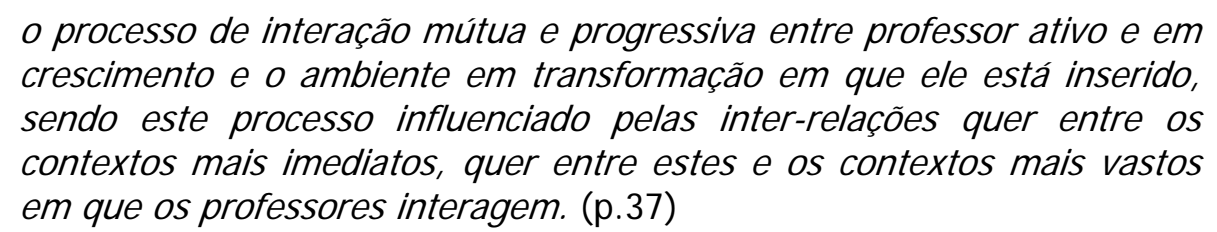

Um processo formativo contextualizado sedimenta-se numa rede de vinculações, ou, segundo Bronfenbrenner, numa rede sistêmica, composta de quatro níveis interrelacionados: microssistêmico, mesossistêmico, exossistêmico e macrossistêmico, cuja caracterização refere-se ao grau de proximidade das relações. Assim, no microssistema configuram-se as relações mais diretas que, no caso de uma escola, dão-se entre cada professor e seus alunos. Por sua vez, esse nível tem implicações e sofre influências dos demais, como é o caso do mesossistema, conjunto de microssistemas que formam um todo institucional. O desenvolvimento profissional do educador é entendido como mudança ecológica, tomando-se a escola como núcleo central de formação, sem que isso resulte aprisionamento ao seu espaço físico.

A perspectiva ecológica de desenvolvimento profissional pretende suplantar dicotomias presentes em outros modelos compreensivos, que tendem a estabelecer padrões de caracterização profissional. Da discussão em torno de tais dicotomias, interessa-nos retomar

\footnotetext{
${ }^{7}$ Segundo Oliveira-Formosinho \& Formosinho (2001), no posicionamento teórico de Bronfenbrenner (1996) temse a conceituação ecológica de desenvolvimento profissional; em Hargreaves e Fullan (1992) e Hargreaves (1996), a ênfase nos níveis contextuais de trabalho e de ensino e em Hord e Boyd (1995), o destaque ao isomorfismo de condições de apoio e reconhecimento tanto para professor quanto para aluno.
} 
as indicadas no quadro abaixo, tendo em conta que, em relação a estas, "a pedagogia ecológica de desenvolvimento profissional encontra uma forma de superação... através da valorização das redes de interação e de uma perspectiva integrada da educação" (OliveiraFormosinho, 2002: 145).

\section{Quadro 1.1 - Dicotomias no Desenvolvimento Profissional dos Professores ${ }^{8}$}

\begin{tabular}{|l|l|}
\hline Enfoque nas práticas & Enfoque em teorias \\
\hline Enfoque no professor como artesão & Enfoque no professor como perito \\
\hline Enfoque na perspectiva do déficit & Enfoque na perspectiva do crescimento \\
\hline Enfoque no indivíduo (perfil do educador) & Enfoque na instituição \\
\hline
\end{tabular}

Muito já se discutiu acerca do antagonismo entre teoria e prática. Ainda assim, a realidade concreta da formação tem caminhado devagar no sentido da práxis, unidade dialética que visa, de um lado, dar sustentação teórica à prática e, de outro, fundamentar a teoria na prática. Ainda são freqüentes cursos e workshops destituídos de qualquer validade prática e, em contrapartida, diversas experiências que se baseiam na vivência pura, na atenção unilateral ao fazer técnico. Porém, aos poucos, apresenta-se um caminho em que a teoria vem ao encontro das necessidades e possibilidades da atuação concreta, real, factível. E é desse encontro que abordagens teóricas vêm sendo revistas e aprofundadas. A acepção ecológica é fruto desse dimensionamento do desenvolvimento profissional como práxis.

Outro ponto de atrito decorre das formas de conceber o professor ora como perito, detentor de um cabedal de conhecimentos produzidos por especialistas sobre/para a educação, ora como artesão, cujos conhecimentos provêm de sua experiência profissional. Se, por um lado, há uma extremada valorização de conhecimentos aos quais os professores só podem ter acesso pela transmissão ou aconselhamento técnico constante, na contramão há quem defenda com entusiasmo o valor dos conhecimentos experienciais empíricos. $\mathrm{Na}$ perspectiva ecológica, os conhecimentos de caráter experiencial são claramente valorizados, mas sua utilidade para o desenvolvimento profissional só passa a existir na medida em que podem ser confrontados, comparados, ampliados, revisados, enfim, refletidos com os conhecimentos teóricos. "Portanto, há que integrar conhecimento estruturado e conhecimento experiencial para construir um percurso de desenvolvimento profissional". (id., p.146).

A unilateralidade entre déficit e crescimento sugere 0 abismo entre compreender 0

8 o quadro completo de dicotomias presentes nos modelos de formação encontra-se em Oliveira-Formosinho (2002: 145). 
desenvolvimento como algo acabado, padronizado, fixo ou como processo contínuo, múltiplo, flexível. A vertente do déficit, cuja origem se reporta às teorias de desenvolvimento infantil, ao ser transposta para o percurso profissional defende que a formação continuada deve incidir sobre as lacunas e deficiências deixadas pela formação inicial. A incompletude profissional deve ser colmatada por propostas de formação que completem ou compensem essas insuficiências. A avaliação das necessidades formativas e a definição da maneira como o déficit será suprimido cabem aos peritos. Nesse caso, o professor perde seu estatuto de profissional consciente, não é reconhecido como sujeito competente para julgar quais são suas necessidades profissionais, nem participar do processo decisório sobre os meios para "compensá-las". No outro extremo, a noção de desenvolvimento profissional é radicada no desenvolvimentismo; entende-se o processo de crescimento linear segundo estágios ou fases de desenvolvimento. Essa visão repercute nas mais diversas tendências de formação continuada, em que se priorizam estágios de desenvolvimento. Outros modelos de formação passam a priorizar o processo de desenvolvimento sem classificar os profissionais segundo estágios pré-estabelecidos. Nessa corrente de pensamento encontram-se, além do modelo ecológico, vertentes de formação que propõem pensar em termos de ciclos de reflexão-ação, propiciando um desenvolvimento multilinear, dissonante, instável, flexível e transitável.

No que diz respeito ao enfoque do plano individual versus institucional, tem-se no primeiro caso que as aprendizagens podem até chegar à sala de aula, mas não beneficiam 0 coletivo, nem se integram às necessidades e possibilidades mais amplas dos sistemas nos quais o professor está inserido. Na história da educação, são inúmeros os exemplos em currículos, propostas de formação, investigações, etc, que reforçam a noção de que desenvolvimento consiste em qualificação das competências, habilidades, saberes, experiências individuais. 0 contexto institucional é negligenciado. No âmbito da formação de professores, tal enfoque originou a determinação de perfis profissionais mais ou menos estáveis, passíveis de serem identificados e modificados, mediante um empreendimento individual, cabendo somente "oferecer aos professores individuais oportunidades para crescimento e proficiência, que tanto podem ser auto como heterodeterminadas, tanto podem ser organizadas como incidentais, realizadas com colegas ou lideradas por peritos." (id., p.148). Na vertente oposta, a instituição é tida como um organismo global e autosuficiente, levando a generalizações, ignorando as diferenças circunstanciais e de cada membro do grupo, apostando numa formação absoluta. A fim de evitar essa distorção, a perspectiva ecológica enfoca a instituição numa posição mais ampla de desenvolvimento, tendendo a levar em conta concomitantemente os planos da profissão, do indivíduo e da organização (Almeida, 1999). Entrelaçados, esses planos resultam na noção sistêmica de 
desenvolvimento, considerando tanto o plano individual como o coletivo.

Pensar ecologicamente o modelo de desenvolvimento profissional é dar muita importância ao sistema de relações entre os microssistemas, isto é, é dar muita importância ao(s) mesossistema(s). Pensar ecologicamente é igualmente incorporar 0 exossistema $e \quad 0$ macrossistema. A perspectiva ecológica assenta na progressiva consideração, cada vez mais alargada, dos contextos sistêmicos em que as educadoras e as suas escolas ou centros vivem. Assim, 0 desenvolvimento institucional é essencial em qualquer pedagogia ecológica de desenvolvimento profissional. (Oliveira-Formosinho, 2002: 148)

Essas dicotomias reforçam programas de formação continuada apoiados numa concepção unilateral, formulando estratégias que tendem a valorizar mais a transmissão de informações sobre perspectivas teóricas 'inovadoras', com forte tendência à abordagem individualista e sob um enfoque compensatório.

É cada vez mais freqüente ligar a formação contínua de professores à inovação pedagógica - não apenas porque importa inovar ousadamente neste terreno, mas também porque se torna imprescindível formar professores para a inovação. É hoje aceito que inovação não é rigorosamente sinônimo de invenção, novidade - mas que representa uma mudança deliberada, original, específica, e que se espera poder contribuir para melhorar a qualidade da educação. (Rocha, 1991 apud Nunes, 2000, 47)

A formação não conduz diretamente à prática inovadora, como assevera Nóvoa (1992). Devido a isso, os programas de formação prescindem de diretrizes para suplantarem dicotomias que distorcem e mistificam seu potencial inovador.

Este parece ser o entendimento presente no imaginário pedagógico de algumas personalidades, pois, não raro, encontramos discursos em que se situa claramente a convicção de que, alterar a prática pedagógica do professor por meio de ações de formação contínua é contribuir para instituir a cultura do sucesso escolar em contraposição à cultura do fracasso escolar. (Nunes, 2000: 48)

Em vista disso, o conceito de Metáfora Ecológica de Bronfenbrenner nos inspira a considerar considera a inovação como possibilidade emergente da prática reflexiva dos agentes que assumem o compromisso de repensar sua profissionalidade e avaliar conscientemente o contexto no qual estão inseridos.

A escola é laboratório e palco de aprendizagens não apenas para o educando, mas também para a docência. Cada sala de aula é um microssistema, em que as práticas educativas são o eixo do desenvolvimento da profissionalidade. Tal desenvolvimento não é descontextualizado da organização institucional, do ambiente em que os profissionais estão inseridos, ou seja, das interações entre os microssistemas (mesossistema); tampouco o 
mesossistema se desvincula das parcerias com outros contextos "que, embora não experienciados diretamente nem implicando a participação ativa do sujeito, são arena de situações que afetam ou são afetados pelo que ocorre nos micro e mesossistemas" (OliveiraFormosinho, 2002: 142). O exossistema envolve, por exemplo, as relações da escola com os centros de pesquisa e ensino universitário, a comunidade, a família e o Estado, constituindose num enlace dinâmico na caracterização de todo contexto educativo. No interior dos micro e mesossistemas há também o macrossistema, que se qualifica como nível de crenças, valores, formas de agir e hábitos pelos quais a experiência da prática e os modos de refletir sobre ela são direta e continuamente afetados.

Segundo esse referencial, o desenvolvimento profissional não é um processo de vivências puramente individuais; ele é necessariamente contextual, do qual fazem parte - de maneira interligada - as dimensões da instituição, das experiências anteriores e das relações profissionais. A inteligibilidade da atuação depende de se compreender a multiplicidade de relações entre os níveis sistêmicos.

O desenvolvimento profissional é um processo vivencial não puramente individual, mas um processo em contexto. 0 desenvolvimento profissional conota uma realidade que se preocupa com os processos (levantamento de necessidades, participação dos professores na definição da ação), os conteúdos concretos ${ }^{9}$ aprendidos (novos conhecimentos, novas competências), os contextos da aprendizagem (formação centrada na escola), a aprendizagem de processos (metacognição), a relevância para as práticas (formação centrada nas práticas) e o impacto na aprendizagem dos alunos. (Oliveira-Formosinho \& Formosinho, 2001: 31)

É de suma importância, também, que a formação continuada conote formação permanente. Isso representa uma significativa mudança das relações entre a escola e os centros de formação/investigação rumo a uma política de integração e ação cooperada. Nessa linha de pensamento, é fundamental que Escola e Universidade se tornem parceiras. Uma parceria que não é de mestre e aprendiz, mas de vínculo mutuamente colaborativo, cuja finalidade é apoiar o desenvolvimento profissional do educador para sedimentar, continuamente, concepção e prática educativas que primem pela qualidade de ensino. Afinal, só há razão para se pensar em formação do profissional educador na medida em que esta reverta em qualidade do atendimento à clientela - que é a razão primeira da existência de todo o universo escolar.

\footnotetext{
${ }^{9}$ Concreto, aqui, tem o sentido de efetivo, pertencente ao plano do desenvolvimento real. Não deve, portanto, ser confundido com a definição de conceito cotidiano que, na acepção de Vygotsky, é caracterizado por sua concretude.
} 


\section{2 - Perspectivas do Desenvolvimento Profissional}

Diferentes prismas, investigações e programas frisam, em uníssono, que o desenvolvimento do educador depende da aprendizagem ativa, com enfática referência às palavras de Dewey, primeiro autor a trazer a discussão à baila. Propõe-se, portanto, que a formação de professores - inicial e continuada - pressuponha decorrer o desenvolvimento profissional do engajamento pleno do professor em seu próprio processo de aprendizagem.

Diversas fontes de referência sobre a área de desenvolvimento profissional (em especial, Handbook of Research on Teacher Education, 1990 e 1996; publicações no Journal of Teacher Education, 1992 a 1997 e o estado da arte sobre a produção científica brasileira realizado por Nunes, 2000) evidenciam a metodologia da resolução de problemas como procedimento ideal para se elaborarem programas e propostas visando ao desenvolvimento profissional.

Os professores devem ser estimulados a experienciar situações, debater idéias e construir hipóteses, experimentando, observando e discutindo resultados para, aos poucos, redefinir a sua própria conceituação.

A partir das experiências de resolução de problemas, desencadeiam-se processos reflexivos de maior amplitude, endereçados à construção e/ou (re)elaboração de significados, a fim de se promover a reorganização dos modos de pensar e agir do profissional. Nessa vertente, a diferença substancial entre as investigações está no modo como os autores abordam esse processo de significação, ou seja, todos levam em conta que se trata de uma reorganização mental, mas é variável o domínio enfatizado no processo, podendo ser conceitual, epistemológico, ético ou de julgamento reflexivo.

Por ter nascido no interior de uma perspectiva desenvolvimentista, é bastante presente a preocupação em estabelecer estágios, cuja caracterização se modula de acordo com a abordagem teórica, a saber: formação do pensamento lógico-formal (Piaget, 1972 e 1973); desenvolvimento ético-moral (Kohlberg e Kramer, 1969); correlação entre comportamento e níveis cognitivos (Bielke, 1979; Blasi's, 1980), desenvolvimento egóico (autoconhecimento, conforme Erickson, 1963), ou tempo de profissão (Katz, 2000).

Com base nas investigações sobre o desenvolvimento profissional docente, realizadas por Sprinthall, Reiman e Thies-Sprinthall (1996); Merseth (1996), Carter (1990) e Burden (1990), o desenvolvimento profissional decorre da luta entre duas forças opostas. De um lado, a força da resistência e da cristalização, respaldada na própria experiência do profissional, nos conhecimentos adquiridos, nos modos de exercer a profissão e nos preceitos ditados pela sociedade; de outro, a força do desejo de mudança e de avanço no desenvolvimento da 
própria profissionalidade. Alguns autores se referem a esse jogo de forças para definir estágios de desenvolvimento, estabelecidos pelo movimento de superação das resistências, a fim de suprir as necessidades formativas, através de questionamentos, criação e experimentação de estratégias para solucionar novos (e velhos) problemas, sendo tão dinâmica e móvel quanto é o fenômeno educativo.

Sprinthall, Reiman e Thies-Sprinthall (1996) demonstram que a opção por caracterizar a vida profissional em estágios tende a definir o desenvolvimento de um ponto de vista linear e crescente. As variáveis eleitas e o número de estágios são mutáveis, mas permanece a suposição de que o estágio seguinte é qualitativamente superior ao antecedente em termos de maturidade e competência.

Dessa maneira, o estágio inicial caracteriza-se por falta de maturidade - perceptível pela visão majoritariamente subjetiva do profissional em relação à realidade - dificuldade de análise das situações mais complexas e tendência a superestimar a afetividade, levando o profissional a confundir seu papel e ser tomado pelas emoções na interação com a clientela. A extremada afetividade e 0 julgamento subjetivo traduzem-se em definições prioritárias da atuação norteadas pelas próprias necessidades.

Em seguida, por conta do tempo e da experiência profissional, o educador adquire uma visão mais objetiva de si mesmo e do outro, distinguindo melhor suas necessidades das de sua clientela; também torna-se capaz de trabalhar em equipe, buscando coerência entre suas ações e as de seus colegas.

No estágio seguinte, observa-se um educador bastante maduro e confiante em suas habilidades, capaz de fazer uma síntese entre a experiência prática e as teorias e conceitos trabalhados. Nesse sentido, notar-se-ia o anseio de consolidar seus conhecimentos e o de saber-fazer (know how).

No quarto estágio de desenvolvimento, o educador torna-se especialista das intervenções psicossociais no cotidiano, com uma consciência clara de seu papel profissional e com desejos de expandir sua área de atuação.

É importante indicar que a maior parte dos estudos privilegiam a caracterização das primeiras fases nessa profissão, tendendo a negligenciar as etapas mais avançadas ao propor caracterizações menos aprofundadas.

De qualquer forma, os dados da literatura deixam transparecer uma concepção idealizada do desenvolvimento profissional, hipotetizando um educador desejoso e capaz de uma evolução profissional, sem colocar em questão os contextos ou as eventuais crises face às dificuldades encontradas na área. Referindo-se aos estudos de Sutton e Sarata, Burden (1990) afirma que, apesar dos autores abordarem o tema das dificuldades, insatisfações e 
dúvidas relativas ao trabalho, consideram a existência de tais fatores somente para os primeiros momentos da carreira.

Schön (1992) retoma o conceito de ação reflexiva de Dewey, concebendo o desenvolvimento profissional como um dinâmico processo em espiral, em que a ação depende da reflexão, e vice-versa. A capacidade de refletir na ação - de pensar sobre a própria prática durante a sua realização - demanda um esforço metacognitivo, através do qual seja possível planejar a ação e agir, a um só tempo.

Alcançar esse nível metacognitivo, no qual o professor possa auto-regular, consciente e autonomamente, crenças, preceitos, sentimentos e conhecimentos acerca da própria experiência profissional é um longo processo, com avanços e retrocessos, cujo término não existe nem pode ser previsto, pois a cada passo em direção à maior complexidade metacognitiva, outros ou novos tipos de problemas surgem, demandando um novo ciclo de ação-reflexão-ação.

Para Schön, os saberes profissionais constituem a epistemologia da prática, que "estaria implícita nos processos artísticos e intuitivos a que os profissionais recorrem quando se deparam com situações de incerteza, instabilidade, singularidade e conflitos de valores" (Cardoso, 1997: 34). A competência artística e a intuição aproximam o educador do artista. O conceito de artistry, de Schön, designa uma sensibilidade operante na prática educativa denominada 'sensibilidade de artista' - assentada no conhecimento tácito, nem sempre passível de ser descrito pelo educador, mas essencialmente inerente e simultâneo à ação; implica flexibilidade cognitiva, que antecipa problemas e cria mecanismos para resolvê-los. Essa antecipação não é radicada na lógica, pois está circunscrita pelo aqui-agora, em que afloram improvisos, suposições e intuições possíveis de interpretação $0^{10}$.

A epistemologia da prática, definida por Schön (1992), circunscreve-se em quatro instâncias dinâmicas: conhecimento na ação, reflexão na ação, reflexão sobre a ação e reflexão sobre a reflexão na ação, sem que se possa qualificar nenhum desses processos como mais complexo que o outro.

O corpo de conhecimentos a que o profissional recorre na ação é criado à luz de sua prática, vinculado à própria experiência, e implica o desempenho profissional, caracterizando-se por seu formato tácito, pessoal e assistemático. Desse modo, como afirma Schön (1990 apud Mayrink, 2000: 49), "parece justo dizer que nosso conhecimento está dentro da ação".

\footnotetext{
${ }^{10}$ Alarcão (1996) discute a conceituação de Schön, comparando-a com a metáfora de designer, que a autora utiliza para se referir ao mesmo fenômeno. Este aspecto da formação docente também é explicitado por nós, no capítulo dedicado à metodologia do projeto formativo, ao explorarmos a relevância da imaginação criadora no design da proposta que realizamos.
} 
Refletir na ação é identificar, durante sua ocorrência, uma situação problemática, visando reformulá-la. Seu caráter complexo reside na necessidade de considerar o conhecimento refletido num contexto anterior (conhecimento na ação).

Refletir sobre a ação retoma a reflexão na ação, agora objeto de análise. Implica o retrospecto do que foi experienciado, das ações realizadas, das questões que ficaram em suspense e da formulação de hipóteses explicativas. 0 distanciamento da ação visa à seleção de aspectos parciais para fomentar novas implicações entre eles, reordenando-os. A conceituação de reflexão sobre a ação parece-nos distinta da reflexão na ação. Schön alerta para o fato de que ambas guardam similaridades. Tanto uma como outra dependem do suporte de conhecimentos, do envolvimento na resolução dos problemas implicados, nas condições profissionais e pessoais para exercer e aprimorar a reflexão.

Imaginemos que, enquanto discute com seus alunos um exercício, o professor se depare com um problema inesperado. Para lidar com ele e dar continuidade ao trabalho, poderá encontrar respostas que, postas imediatamente em ação, afluem para um patamar mais profundo e igualmente surpreendente de prosseguir com o debate. Refletindo na ação, 0 professor poderá julgar tanto sua ação quanto a dos educandos de maneira distinta daquela que serviu, até o exato momento, para compreender seu saber-fazer.

Por outro lado, a reflexão sobre a ação está envolta por armadilhas, determinadas pelo distanciamento da ação, aspecto que aparentemente torna a 'reflexão sobre' mais efetiva do que a reflexão na ação. Tanto pode enviesar a interpretação de fatos, seqüência de ações, não ditos e não observados, quanto implicar a construção de novos conhecimentos, ampliando e solidificando o sistema conceitual que orienta sua prática. Aquele professor, por exemplo, poderia anular observações cruciais na determinação dos elementos que compuseram a aula, creditando a determinados acontecimentos uma importância superior à que efetivamente tiveram e negligenciando outros, valendo-se deste conjunto de interpretações em ocasiões futuras.

Refletir sobre a reflexão da ação reporta-se a um maior distanciamento. Todavia, refletir sobre o refletido da ação é um processo que ultrapassa os condicionantes de uma dada experiência, levando "o profissional a progredir no seu desenvolvimento e a construir a sua forma pessoal de conhecer" (Alarcão, 1996: 19). Na reflexão sobre a reflexão, pretende-se generalizar e abstrair caracterizações e processos da própria prática. Demanda conhecimentos de diferentes fontes para "descrever, analisar e avaliar os vestígios deixados na memória por intervenções anteriores" (Pérez Gómez, 1992: 105).

Para Kincheloe (1997: 125) o processo de construção de conhecimento e de desenvolvimento docente fundamenta-se na teoria piagetiana. 0 autor reconceitua a 
epistemologia genética de Piaget como 'epistemologia construtivista crítica':

Quando nós aplicamos nossos entendimentos do construtivismo crítico e desestruturação, começamos a ver que as pessoas nas situações diárias não fazem desta maneira formalística e empírica (transferência universalizadora). Nossa noção de acomodação crítica nos diz que nós remodelamos as estruturas cognitivas para contar com aspectos únicos do que está sendo percebido no novo contexto. Através do conhecimento de uma variedade comparável de contextos nós começamos a entender similaridades e diferenças - nós aprendemos de nossas comparações de diferentes contextos... Nós começamos a pensar em termos de acomodação antecipatória, ou seja, nós antecipamos o que podemos encontrar em situações similares, que estratégias podem funcionar em nossas tentativas para trazer resultados emancipatórios.

O desenvolvimento profissional provém da modificação cognitiva, tanto do ponto de vista estrutural como do funcionamento psicológico. Isso significa que o aprendizado, internalizado, reorganiza concepções, coloca em xeque as preexistentes e desvela novos meios de compreender os fenômenos da realidade. Essa recognição não é mecânica, está vinculada dialeticamente às transformações do funcionamento psíquico.

Tal processo, por sua vez, constituído de avanços e retrocessos, não se dá de dentro para fora; ele é sustentado pelo plano interpsicológico. A importância desse plano no processo de desenvolvimento é destacada por Sprinthall, Reiman e Thies-Sprinthall (1996: 692) ao se reportarem à posição de Vygotsky para reafirmar o papel das interações sociais, tal como as ocorridas em reuniões de pequenos grupos, "onde o diálogo é o primeiro método de produção de crescimento cognitivo-estrutural no aprendiz".

A nova aprendizagem inicia-se com uma perturbação relativa a aprendizagens anteriores e transformadas em instrumental para/da ação e é confrontada com problemas dos quais 0 atual funcionamento cognitivo não pode dar conta satisfatoriamente.

Evidencia-se como um dos maiores entraves para o desenvolvimento profissional a inadequação de sistemas de pensamento para resolução de novos problemas.

Estudos comprovam que tal problema não tem solução simples, pelo fato de que se exige do educador uma 'mudança conceitual', traduzida não apenas num modo de pensar mais sofisticado, mas numa prática reflexiva.

As resultantes das pesquisas de King e Kitchener (1994 apud Sprinthall, Reiman e ThiesSprinthall, 1996: 675) são importante referência para nosso estudo. As autoras constataram que o desenvolvimento cognitivo apresenta variações segundo três modalidades: dualismo, relativismo e julgamento reflexivo, que podem coexistir em diferentes momentos do desenvolvimento profissional. Esse dado fortalece a interpretação de que, mesmo no início de um percurso formativo, há possibilidade de haver indícios de mudanças em processo. 
Num estudo longitudinal de casos, de acordo com a metodologia da resolução de problemas, as autoras reportaram-se a cenários específicos, como o da construção das pirâmides do Egito ou o de soluções para um desastre ecológico. Mediante a apresentação desse gênero de problemas, solicitaram a oitenta professores que formulassem hipóteses para solucioná-los. Das entrevistas, reaplicadas anualmente durante dez anos, obtiveram correlações estatísticas expressivas da existência dessas três modalidades de pensamento.

A partir das informações coletadas, as autoras formularam três níveis de desenvolvimento, em direção ao julgamento reflexivo. Inicialmente, predomina um pensamento concreto e heterônomo. O nível intermediário constitui-se do pensamento quase abstrato/auto-reflexivo. 0 último nível configura-se de um julgamento reflexivo verdadeiro, em que ação e pensamento são auto-regulados, e da interdependência entre eles formula-se a prática reflexiva.

As autoras concluem que as três modalidades não se apresentam linearmente ao longo do desenvolvimento, mas são coexistentes. Há íntima relação com o domínio de conhecimento a que se referem, podendo haver efetivo julgamento reflexivo acerca de um determinado aspecto e, de outro, manterem-se os níveis mais primários de pensamento. Os resultados apontam uma correlação significativa entre desenvolvimento do julgamento reflexivo e continuidade de estudos informais na carreira.

As investigações de King e Kitchener corroboram os achados de outras pesquisas, como as de Kohlberg \& Kramer e as de Dewey sobre o desenvolvimento não-linear de conceitos através da solução de problemas científicos. Portanto, desenvolvimento profissional é um processo lento, e seu maior obstáculo deve-se à resistência para a mudança. 0 fator "tempo de experiência" não prediz o desenvolvimento do julgamento reflexivo, sendo muito mais relevante avaliar as condições institucionais no sentido de promover desenvolvimento ou, ao contrário, levá-lo a declinar, retroceder, permanecer estagnado. 0 axioma de que 0 desenvolvimento profissional modula-se por estágios conforme idade/tempo de experiência foi abalado pela investigação das pesquisadoras anteriormente citadas. Em síntese, dentre os principais fatores de desenvolvimento profissional, é indispensável contar com o estímulo, a valorização e o suporte oferecidos pelo contexto profissional para promover a continuidade de estudo do educador, visando valorizar e apoiar o enriquecimento da profissionalidade e contribuir para possíveis mudanças.

\subsection{1 - Desenvolvimento Profissional como Recognição}

Alguns autores abordam desenvolvimento profissional como recognição, isto é, enfatizam que os programas de formação de professores sejam metodologicamente estruturados a fim 
de serem compatíveis com a complexidade inerente à recognição. Muito semelhante a propostas derivadas de outras abordagens, essa estrutura deve privilegiar um processo centrado no contexto escolar, pautado no diálogo e, particularmente, envolvendo os professores em pequenos grupos que se reúnem periodicamente para debater problemas relativos à prática educativa.

Segundo essa linha de investigação, para que os professores venham a adotar novas e mais complexas estratégias de resolução de problemas, eles dependem crucialmente do suporte grupal, dadas as dissonâncias afetivas repercutidas no autoconceito e na autoestima. Como denomina Furth (1981, apud Sprinthall, Reiman e Thies-Sprinthall 1996: 692), idealmente o suporte grupal é promovido através de uma atmosfera de reflexão relaxada. Para a recognição, é de suma importância reconhecer as necessidades afetivas tanto quanto as cognitivas, enfatizando tanto os conteúdos da ordem dos afetos quanto os relativos ao conhecimento intelectual. De fato, é opinião unânime dos pesquisadores desta vertente que um programa de recognição (desenvolvimento profissional) que desconsidere a afetividade como parte essencial esteja fadado ao fracasso.

Mais recentemente, fala-se em modelo de reciprocidade para se referenciar à implicação da afetividade no desenvolvimento profissional. "A reflexão experiencial e afetiva é o ponto de partida para o desenvolvimento do educador" (Sprinthall, Reiman e Thies-Sprinthall, 1996: 693).

A proposição de desenvolvimento profissional como desenvolvimento construtivista também se refere à recognição como processo de aprendizagem. O conhecimento é construído "através de experiências relevantes em que se presentificam o cabedal de informações, fatos, experiências anteriores próprias e dos companheiros, imbuídos de significação, sobre um domínio ou situação específica, influenciado pelo contexto sóciocultural e, em geral, menos cognitivo e menos governado pelos princípios abstratos da visão tradicional de aprendizagem" (Black e Ammon, 1992, 324).

Optamos por atentar à dinâmica do processo de aprendizagem-desenvolvimento, com suas estagnações aparentes, descontinuidades, multiplicidade de fatores e de situações que ora promovem ora dificultam o trabalho.

A profissionalidade docente é um processo permanente de aprendizagem (life long learning process). Suas diferentes abordagens tendem a estabelecer estágios e fases, levando em conta uma das variáveis supracitadas. Para nosso interesse de estudo, o desenvolvimento profissional é multilinear, distanciando-se da tradição psicológica desenvolvimentista e, portanto, do estabelecimento de estágios do desenvolvimento profissional. 
Um dos dois aspectos que nos levam a tal opção é a ênfase na contextualidade da formação profissional. Os contextos de trabalho estão profundamente ligados às questões e problemas que o professor vivencia em sua profissionalidade. A literatura recente sobre desenvolvimento profissional aponta que compreender melhor a relação do contexto de trabalho com a vivência da profissão ilumina 0 entendimento sobre os ciclos de desenvolvimento, sob um enfoque sistêmico das experiências e aprendizagens que se constituem mais significativas na profissionalidade.

O outro aspecto relaciona-se ao fato de que a pesquisa está centralizada nos primeiros indícios de desenvolvimento, quando o que se apresentam são potencialidades em ação, ainda não consolidadas.

Selecionamos a produção teórica mais consistente para apoiar nossos objetivos de formação e investigação e ressaltamos a necessidade de mudanças da escola visando à melhoria da qualidade do ensino. Primeiro, dirigimo-nos à prática docente, reconhecendo a vasta e dinâmica rede de fatores que legitimam sua complexidade; depois, adentramos nas questões que se aproximam do campo delimitado a que se refere este estudo: as tessituras do desenvolvimento profissional docente.

A abordagem reflexiva, em particular na linha teórica desenvolvida por Schön (epistemologia da prática), releva o papel da construção de saberes no campo de ação, ou seja, no interior da prática profissional.

É por esse prisma que aludimos à epistemologia da prática, de Schön, para enfatizar que aspiramos, pelo projeto formativo realizado, principiar as mudanças no nível de saberes específicos que colaborem para a compreensão da estrutura e do funcionamento da atuação educativa e auspiciar sua transformação. Esses saberes dizem respeito ao que denominamos ludo-educação ou educação lúdica (terminologias empregadas no cenário internacional para aprendizagem escolar, cuja significação é propor ensino formal apoiado pela mediação de atividades lúdicas). 


\section{2 - EDUCAÇÃO LÚDICA NA FORMAÇÃO E NA PRÁTI CA DOCENTE}

Desde o início do planejamento da proposta lúdica de formação de professores, tivemos ciência das críticas às propostas indicadas aos educadores por agente externo. 0 movimento contrário ao modelo intervencionista impulsionou estudos etnográficos - como os de pesquisa-ação - e programas de formação - como os de Formação em Contexto, realizados em Braga (Portugal), pela Associação Criança (para educadores de primeira infância).

Reconhecer o posicionamento contrário aos projetos de formação com objeto definido $a$ priori pelo pesquisador foi um dilema com que tivemos de lidar, mediante 0 fato de que nosso intuito (a ludo-educação) foi determinado antes mesmo de entrarmos em contato com escolas que pudessem aceitar o trabalho ou, mais que isso, que se interessassem em integrar jogos e brincadeiras ao ensino.

Desde a seleção da escola, cuidamos para que as idéias levadas às professoras sobre ensino lúdico efetivamente fossem ao encontro de suas necessidades formativo-educativas, solidificassem a colaboração e a cooperação entre os membros do corpo docente e contribuíssem com seu desenvolvimento profissional.

Os estudos sobre a relação entre jogo e educação apontam, há várias décadas, que não há somente o problema de multiplicidade de sentidos entre jogo propriamente dito e jogo educativo. No entanto, a retórica de valorização dessa atividade infantil como educativa mantém-se extensiva e irremediavelmente no discurso dos educadores.

...parece não interessar [à escola] o que, e de que forma, a criança pode ser capaz de projetar de novo, e sim o que é capaz de reproduzir. 0 saber escolar exige, em geral, processos psicológicos específicos, na linha oposta à da criação. Talvez também por isso, sistematicamente, [trata-se] o jogo e os objetos lúdicos, recentrando seus significados, agora sobre as finalidades educativas usuais, como primados do saber. (Rocha, 1997: 81)

As palavras de Maria Silvia Rocha revelam com veemência o maior dos obstáculos a transpor para creditar ao jogo um papel emancipatório no interior do contexto educativo.

Por intermédio de um estudo com professores (de Ensino Fundamental, da rede pública da cidade de Londrina/PR), viemos a conhecer mais detalhadamente o discurso docente que valoriza o jogo ao mesmo tempo que desconhece como vinculá-lo aos objetivos escolares.

Das respostas a questionários, abordando vários aspectos da relação entre jogo e aprendizagem, 93\% afirmam a importância do jogo à educação. Destes, somente $2 \%$ indicam ter "utilizado" jogos e brincadeiras em sala de aula para alguma finalidade de aprendizagem, indicando razões como a falta de tempo para inserir atividade lúdica no programa curricular, materiais lúdicos e apoio pedagógico, além das dificuldades em lidar 
com classes numerosas (Pimentel, 2000).

Num estudo acerca das relações entre jogo e prática pedagógica de professores alfabetizadores, Uemura (1988) indica que, na rede pública de São Paulo, 55,56\% dos entrevistados entendem que o brinquedo (atividade lúdica) é dotado de características educativas. Há concordância quase unânime $(97,87 \%)$ de que o jogo é uma atividade importante para a prática pedagógica. $72,34 \%$ dos professores afirmam não recorrerem ao jogo como peça fundamental para a aprendizagem.

Da amostra de professores consultados, reunindo as redes pública e particular,

para a maioria dos professores $(94,44 \%)$ é possível utilizar o brinquedo no desenvolvimento do conteúdo de alfabetização... quase a metade deles $(41,55 \%)$ identificou alguma finalidade pedagógica; e muitos (78,72\%) não utilizaram o brinquedo na rotina escolar. Para esses professores é possível, mas não realizável. O irrealizável se deve à formação acadêmica e profissional sobre o assunto, à falta de condições físicas e materiais ou, ainda, à inaceitabilidade ao desafio de concretizar o acreditável. (Uemura, 1988: 148)

Em sua pesquisa de doutoramento, Maria Ângela Barbato Carneiro (1990) incursiona pela educação lúdica, elaborando um programa de inserção de jogo para o ensino superior ou, mais precisamente, à disciplina Estrutura e Funcionamento do Ensino Fundamental e Médio. Como professora responsável por tal disciplina, a autora questiona seu próprio saber-fazer docente, cuja preocupação maior é com o estado da educação e com a formação do educador.

$\mathrm{Na}$ experiência envolvendo jogo e adultos ${ }^{11}$, Carneiro hipotetiza se a aprendizagem do adulto - no caso, do aluno de licenciatura - pode se beneficiar do jogo, pressupondo que:

O jogo é uma atividade importante, que desperta o interesse e leva à participação. Isso se reflete também na sala de aula, onde pode ser usado, fazendo com que os estudantes participem ativamente no processo ensino-aprendizagem. Por despertar o interesse, o jogo causa prazer, colaborando para uma aprendizagem significativa, já que jogar é um desafio e permite que o estudante aprenda através da própria descoberta, pois desperta a curiosidade e a pesquisa. (Carneiro, 1990: 8)

$\mathrm{Na}$ definição de jogo como "estratégia de aprendizagem para adultos", Carneiro se reporta às características que, comumente, são explicitadas para fins educativos em geral: a contradição inerente à atividade lúdica (liberdade versus regra, meio de expressão e

${ }^{11}$ A relação entre jogo e aprendizagem do adulto é um tema que merece maior investigação. Há, porém, um extenso elenco de pesquisas relativas ao jogo na aprendizagem escolar. Nessas obras, os temas principais são 0 jogo na instituição de educação infantil, a relação da criança com o brincar ou as representações do adulto sobre atividade lúdica na educação de primeira infância (França, 1990; Garkov, 1990; Otero, 1996; Puglisi, 1997; Rabelo, 1998; Wajskop, 1996; Pinheiro, 1992; Veiga, 2000; Rabioglio, 1995). 
iniciativa versus gerador de conflitos); sua motivação intrínseca; a seriedade com que o jogador se dedica ao jogo; o favorecimento à fantasia; criatividade e curiosidade.

Segundo Carneiro ${ }^{12}$, o jogo tem relevância na relação entre desenvolvimento e aprendizagem porque envolve atividades mentais como percepção, representação, pensamento; "ao jogar, o ser humano precisa compreender, antes de mais nada, a sua própria ação, para que possa realizá-la adequadamente". (id., p.38).

A partir de observações e entrevistas com os estudantes participantes da experiência, a pesquisadora obtém resultados favoráveis ao processo de aprendizagem - indicadores de forte envolvimento afetivo com a disciplina; mudança de valores quanto à atividade lúdica (a princípio, considerada infantil); ativa participação da classe; crescente aumento de ações investigativas e de experimentação e compreensão do conteúdo programático da disciplina.

São realizadas entrevistas com outros professores universitários, durante a pesquisa, constatando-se que, embora valorizado como aliado da educação em geral, na prática se mantêm distanciamento, desconhecimento e preconceito acerca do potencial educativo do jogo. Entretanto,

o jogo interessa, desafia, ensina. Por meio dele, o sujeito/aluno engajase no processo educativo de forma global: toda a sua afetividade vem à tona, utiliza várias formas de representação, e a memória é recuperada na medida em que se evocam os conteúdos das regras, ou são associados a situações análogas, desenvolve a observação e, ainda, possibilita a reflexão. (id., p.185)

E mais adiante:

A escola não pode prescindir do jogo. Se ao educador cabe ensinar aos seus alunos conhecimentos (reais), necessários à sua participação na cultura e sociedade, tendo em vista determinados objetivos, o jogo deve fazer parte do seu processo de formação. Por essa razão, propomos sua inclusão no currículo como um tema a ser tratado pelas disciplinas mais específicas do ponto de vista de instrumentalização. (id., p.188)

\section{1 - O J ogo e a Prática Docente}

Na obra Jogo e Educação (1998), Brougère analisa sociologicamente discursos que valorizam o jogo no âmbito escolar, abordando a questão da natureza polissêmica do jogo. Para o autor, não há um paradigma único para conceituá-lo nem designar seu papel no

\footnotetext{
12 Para demonstrar quanto já se discutiu acerca do papel do jogo na educação, Carneiro retoma proposições de diversos autores acerca do jogo, com destaque a Huizinga (1943), Henriot (1983), Caillois 1958), Freinet (1946), Brougère (1987, 1998), Chateau (1987), Barthes (1975), Benjamin (1984), Vygotsky (1988), Leontiev (1988), Bruner (1976/1986), Piaget (1978), entre outros. Estas são apenas algumas da miríade de significações educativas para o jogo. Historicamente, um olhar educativo sobre o jogo existe desde a Antigüidade, e é impossível desprezarmos o pensamento dos teóricos do Romantismo, tais como Rousseau, Pestalozzi e Fröbel, cuja contribuição para se erigirem as acepções contemporâneas é consagrada.
} 
desenvolvimento e suas implicações educativas.

Da heterogeneidade conceitual à distorção e parcialidade com que alguns referenciais foram tomados, repercutiram múltiplas representações de jogo e, particularmente, de jogo educativo. 0 antagonismo é visível nas propostas decorrentes, concebendo o jogo ora como ação livre da criança, ora como atividade orientada pelo professor no ensino de conteúdos escolares.

De um lado, divulgou-se um modelo educacional em que jogo é expressão da natureza eminentemente 'boa' da infância, numa reedição do romantismo do século XVII. Sob esse enfoque, subentende-se que basta deixar a criança brincar, sendo desnecessário preparar o ambiente, adequar os espaços para a brincadeira e formar apropriadamente os professores.

Numa linha de pensamento diametralmente oposta, o modelo transmissivo de ensino enfatiza a realização de tarefas pré-estabelecidas e controladas pelo professor, bem como a contenção disciplinar. Se presente, o brincar ocupa o lugar de apêndice, em salas pequenas transformadas em ludotecas, onde as crianças não têm acesso livre aos materiais, cabendo ao professor o preparo das atividades, a seleção dos brinquedos e a direção das brincadeiras.

No Ensino Fundamental, predomina a ênfase no treino progressivo de habilidades específicas e transmissão de conhecimento, através de memorização, cópia de exercícios e repetição de tarefas. Se permitidos, os jogos são majoritariamente utilizados com a finalidade de manter o silêncio e preencher o tempo dos alunos que já terminaram suas lições.

Integrar atividades lúdicas à prática docente com clara pretensão de torná-las mediadoras do processo de ensino-aprendizagem significa empreender uma leitura nova das tarefas escolares, torná-las desafiadoras, objeto de curiosidade e de promoção da criatividade do educando.

A dimensão lúdica de educação só existe se conservadas as condições de expressão do jogo. A aprendizagem depende do respeito aos interesses dos educandos e da garantia de que tenham controle sobre a brincadeira. Ao contrário, o jogo só existe por mera analogia se dimensionado pelo adulto, servindo implicitamente para desviar a criança rumo a uma 'boa' causa: a educativa. Como adverte Brougère (1998: 187), "ao batizar de 'jogos' atividades tão distantes da cultura lúdica da criança, podemos perguntar se elas ainda são da ordem do jogo".

Segundo os referenciais norteadores das novas diretrizes educacionais, a "atividade autoiniciada, e sobretudo autodirigida, [é] o ponto de partida necessário para uma verdadeira aprendizagem" (Brasil, 1998: 76). Exercícios e outros meios didáticos, fundamentados na 
crença de que é preciso treinar habilidades, cedem lugar às atividades que exigem 0 raciocínio na solução de problemas.

Aparentemente, a natureza livre e espontânea do jogo é incompatível com a busca de resultados educativos. Contudo, as duas instâncias são espaços privilegiados de elaboração de conhecimentos e de desenvolvimento do comportamento autônomo e consciente. É nesse sentido que o jogo pode ser visto como aliado do processo educativo formal, pois: a) contempla várias formas de representação mental da realidade; b) permite ação intencional; c) requer construção de um sistema de regras; d) demanda manipulação de objetos (concretos e simbólicos), e) facilita o desempenho de ações motoras e f) implica no estabelecimento de interações sociais.

Selma Wassermann (1990) ${ }^{13}$ apresenta uma proposta teórico-metodológica sobre o jogo para o ensino, denominada Jogo - Análise - Novo Jogo, que visa construir condições de aprendizagem favoráveis ao desenvolvimento da confiança dos alunos em seu próprio potencial. O material essencial para a elaboração desse sistema foi colhido através de observações e conversas com professores de diferentes níveis de ensino. Para a autora, esta é uma das melhores fontes para o pesquisador interessado em elaborar uma perspectiva da práxis ludo-educativa.

O Jogo - Análise - Novo Jogo é um sistema estruturado em três fases:

$1^{\text {a }}$ fase ("jogo"): as atividades lúdicas são postas como desafios intelectuais e criativos aos quais os estudantes buscam dar soluções;

$2^{a}$ fase ("análise do jogo"): intensa interação das crianças entre si e com outros mediadores - o professor ou orientador e os materiais de consulta - auxiliando a atitude reflexiva, a (re)construção de conceitos, as redes de interpretação e de significações relevantes;

$3^{\text {a }}$ fase ("novo jogo"): a atividade lúdica é remodelada a fim de propor um desafio mais complexo; a ação e a reflexão seguem lado a lado num nível mais autônomo e consciente do que 0 experienciado.

Wassermann defende que o jogo visa propiciar às crianças o desenvolvimento de sua capacidade investigativa. Jogando e refletindo acerca do jogo, podem reelaborar suas

\footnotetext{
13 Selma Wassermann, pesquisadora canadense, há anos dedica-se à educação com jogos para primeiras séries do Ensino Fundamental em seu país. Sua proposta - sustentada pela tríade "jogo; análise do jogo; novo jogo" diferentemente de nosso ponto de vista, destina-se à exclusividade do jogo como mediador do ensino. Para nós, o jogo deve estar integrado a outras atividades didáticas, presentes no cotidiano das escolas. Vale acrescentarmos ainda que Wassermann compartilha das idéias vygotskianas sobre as relações entre desenvolvimento e aprendizagem; mediação, interação e internalização; linguagem e organização do pensamento, além de estar presente em seu modelo a noção de zona de desenvolvimento proximal.
} 
experiências. Depois, através de novas situações de jogo, são encorajadas a alcançar outros níveis experienciais e de organização de suas aprendizagens. Protagonizando o jogo, "aprendem a pensar, e seu poder de iniciativa aumenta, bem como sua responsabilidade de compreensão dos conceitos ou das idéias importantes contidas no programa curricular aumenta" (1990: 37).

A motivação intrínseca do desafio lúdico instiga os alunos a suplantar desigualdades e negociar divergências, resultando em articulação, compreensão e organização de conceitos.

Por sua vez, o professor pode observar e acompanhar os diferentes estilos, ritmos e talentos dos alunos que formam um mosaico do acontecer da brincadeira, não de maneira aleatória, mas fornecendo elementos para mediação e avaliação da aprendizagem durante o jogo. Embora sejam reconhecidas a significação e a relevância da observação no âmbito educativo, o aprimoramento desse instrumental é pouco discutido.

Wassermann reserva uma atenção especial à observação, postulando que esta deva ser uma das principais atividades docentes. Em seu esquema, o professor deve observar as necessidades educativas e preferências individuais dos alunos para definir a articulação entre atividade lúdica, conteúdo, procedimentos e estratégias.

Desde 1988, Wassermann desenvolve um programa de pesquisa intitulado Projeto Ciência Pensamento, sob a forma de um estudo de campo, pretendendo a implementação de programas de formação de professores baseados na perspectiva de Jogo - Análise - Novo Jogo.

Dentre os pesquisadores envolvidos, Christensen ${ }^{14}$ desenvolveu um estudo para avaliar a contribuição dos programas de formação realizados nessa vertente teórica. Mediante consulta aos participantes, a proposta de aprendizagem lúdica foi favorável ao processo educativo, considerando que

os níveis de desenvolvimento das competências aumentam, bem como o
entendimento conceptual... Os estudantes de idade adulta são
particularmente eloqüentes ao afirmar que tais contextos de
aprendizagem Ihes dão confiança em si próprios e os levam a
desenvolver as suas capacidades. (id., p.38)

O papel dos formadores em relação aos educadores é homólogo ao que se propõe para a sala de aula, entre professor e alunos: incentivar a experimentação, apoiar e provocar a elaboração de hipóteses, acompanhar o momento de testá-las e mediar a reflexão sobre os resultados, contínua e sistematicamente.

\footnotetext{
${ }^{14} \mathrm{Na}$ área da formação de professores, a perspectiva de Jogo - Análise - Novo Jogo é realizada através da parceria com universidades canadenses e norte-americanas, bem como por cursos extracurriculares. 0 autor citado é docente da Harvard Graduate School of Business.
} 
A ênfase nos processos reflexivos cerca-se do ideário proposto por Schön. Refletindo sobre sua ação, o professor torna-se capaz de controlar sua atuação e elevar seu desenvolvimento profissional, pois "se é verdade que as crianças desenvolvem seu poder pessoal através destes métodos, tal não é menos válido para os próprios professores" (id., p.39).

Todo o processo de ensino-aprendizagem é centrado na experimentação, através de jogos. Os conceitos a serem aprendidos são oriundos da investigação, da observação e da sistematização do que se realizou no jogo.

Geralmente estruturados para a resolução conjunta, em pequenos grupos, os desafios lúdicos propõem o desenvolvimento simultâneo de atitudes, comportamentos e valores importantes para o exercício da colaboração, da cooperação, da divisão de funções e do reconhecimento de esforços individuais.

O cenário de aprendizagem lúdica merece atenção especial, pois a disponibilidade de materiais, o acesso a eles, bem como a disposição dos alunos em classe são fatores decisivos na criação de condições favoráveis para o desenrolar do jogo educativo, o qual só faz sentido em sala de aula se disposto nas mãos dos alunos.

Por sua vez, o professor se depara com um novo dilema: manter sua autoridade e, ao mesmo tempo, apropriar-se do papel de orientador, o que exige repensar sua função no processo de ensino-aprendizagem.

$\mathrm{Na}$ acepção de Wassermann, algumas características alargam a contribuição do jogo ao processo de construção de conceitos, em particular as que definem o jogo de investigação:

$\stackrel{\leftrightarrow}{\leftrightarrow}$ não tem solução predeterminada, permitindo variação de respostas/soluções;

$\stackrel{\leftrightarrow}{\leftrightarrow}$ contribui para a formação de idéias, ao contrário de atividades que evocam informações isoladas;

$\stackrel{\leftrightarrow}{\rightarrow}$ desafia o pensamento, estimulando os alunos ao enfrentamento dos desafios intelectuais inerentes a esse tipo de jogo;

$\Leftrightarrow$ tem respaldo nos conceitos mais relevantes do programa curricular;

$\stackrel{\leftrightarrow}{\rightarrow}$ constitui-se de várias tarefas, oportunizando o desenvolvimento de formulações conceituais;

$\stackrel{\leftrightarrow}{\rightarrow}$ desenvolve-se em grupo, realçando a cooperação e o desenvolvimento de ações em parceria;

$\stackrel{4}{4}$ promove a investigação coletiva, através da qual conceitos e procedimentos são construídos em meio a questionamento, complementaridade e debate, favorecendo a própria complexidade conceitual;

$\leftrightarrow$ estimula a troca de idéias e a especulação, abrindo caminho aos processos 
metacognitivos dos educandos.

Nossas observações apontam que jogos de imaginação e de exploração, por exemplo, também atendem a esses requisitos e podem flexibilizar a organização do cenário de aprendizagem. Consideramos recomendável a variabilidade de tipos de jogos, a serem escolhidos em conformidade às peculiaridades de cada situação específica do processo de aprendizagem.

Na mesma linha de raciocínio, as atividades antecedentes, preparatórias do jogo, também têm finalidades específicas; por isso, é enriquecedor possibilitar que sejam igualmente assumidas pelos alunos. Propor às professoras a inserção da confecção de jogo pelos alunos beneficia a compreensão dos mecanismos basilares do jogo e, por conseguinte, de seus vínculos com temas e conteúdos a serem articulados e desenvolvidos através da atividade lúdica. O preparo do cenário ludo-educativo pelo docente envolve desde a disposição de materiais e a organização dos alunos até os procedimentos estritamente relacionados aos objetivos escolares almejados com o jogo.

O conhecimento sobre os alunos é igualmente decisivo na configuração da proposta lúdica. Por essa razão, não se pode fixar mecanismos específicos do ensino lúdico. É pela observação e avaliação contínuas do processo de aprendizagem dos alunos, da forma como se comportam, do conhecimento sobre suas preferências, do nível de independência, etc, que o educador pode extrair as informações de maior magnitude acerca da formatação adequada da atividade lúdica para o ensino-aprendizagem.

Ao agregarmos às funções do educador a de organizador do cenário de aprendizagem pelo lúdico e elencarmos os fatores imprescindíveis à formulação da atividade, não sugerimos dirigir e cercear a liberdade dos alunos em desfrutarem da situação de jogo, segundo suas próprias condições reais e potenciais. Ao contrário, essa organização embasa, mas não direciona a ação no jogo, pois cada grupo toma um sentido próprio, altera e define regras conforme as negociações entre pares, estabelece soluções que surpreendem 0 educador, seja pela perspicácia, criatividade, ousadia, etc.

É justamente para garantir oportunidade aos alunos de assumirem ativamente a direção do jogo que o educador orienta suas decisões na preparação e na proposição da atividade. Durante a execução do jogo, é salutar incentivar ocasiões em que seja conduzido pelos alunos para instâncias diversas das orientações oferecidas, desde que ainda assim atendam aos objetivos.

Como referenda Wassermann, arquitetar uma experiência de aprendizagem com jogos requer do professor consciência dos procedimentos para construção de conceitos pelos alunos "através do seu envolvimento ativo com materiais selecionados, e de como as 
operações de pensamento serão inerentes aos jogos" (1990: 42).

O desafio, ao docente, refere-se à adequação de oportunidades para que a aprendizagem de determinados conceitos se constitua, mediante o modo de preparar 0 ambiente, propor o jogo e observar a atuação discente no jogo e depois dele, sempre buscando aperfeiçoar pela reflexão a simbiose entre condições de ensino, programa curricular e conhecimento sobre os alunos com as estratégias de proposição das atividades lúdicas.

Aqueles requisitos indicados anteriormente implicam diversas atitudes dos alunos durante o jogo, visando resolver o desafio: manipular variáveis, gerar hipóteses, investigar e testar, observar, classificar dados, avaliar condições, decidir e, para a manutenção do jogo, interagir negociando, colaborando e complementando, mesmo nos casos em que haja competição explícita.

Tais experiências favorecem a compreensão dos conceitos, diretamente vinculada à resolução do desafio, aprendizagem de valores e desenvolvimento de comportamento responsável em grupo.

Finalizado o tempo de jogo, cuja duração varia conforme a proposta e os objetivos, é de suma importância um tempo de análise, isto é, 'reflexão sobre a ação', conforme a terminologia empregada por Schön, à qual Wassermann alude.

Neste momento, o gênero de questões, comentários e incentivos formulados pelo professor não visam colher informações e respostas únicas, mas se destinam a orientar os alunos na continuidade e no aprofundamento de suas investigações. Dessa forma, a ação reflexiva dos alunos poderá ser desencadeada e organizada pelo modo como o professor procede à fase de análise do jogo, tal como os exemplos abaixo:

a) enfocar e descrever suas observações;

b) reconhecer os saberes precedentes e de que modo se implicaram na atividade e na formulação das hipóteses construídas durante o jogo;

c) produzir novas inquietações, para as quais será destinado o novo jogo;

d) distinguir cada fase de execução do jogo;

e) definir os procedimentos mais produtivos na divisão de tarefas entre membros do grupo;

f) detectar problemas surgidos durante o trabalho e explanar sobre soluções encontradas;

g) reconhecer e se apropriar das sensações e sentimentos gerados pelo jogo;

h) reconhecer competências próprias e dos colegas;

i) relacionar condições do cenário com as produções criativas elaboradas; 
j) sugerir mecanismos e/ou estratégias de ação a serem experimentados no novo jogo.

À primeira vista, o vivenciado se apresenta de maneira confusa, desordenada e indefinida. Os sentidos se emolduram à medida que, a partir das intervenções do educador, a vivência é comunicada, visando ao redimensionamento das ações, interações, decisões e soluções derivadas da experimentação.

Tal busca de sentido resulta em descobertas, conhecimentos novos e compreensão mais aprofundada tanto do que se tenha realizado quanto das possibilidades futuras.

O processo de experimentação-avaliação de Wassermann guarda grande similitude com a perspectiva de Schön. A pesquisadora alude à correspondência entre a fase de análise e a reflexão-sobre-a-ação, enquanto "o jogo é o estádio de reflexão na ação, em que todo o processo de Jogo - Análise - Novo Jogo estimula exatamente o mesmo tipo de capacidade para solucionar problemas que Schön descreve." (Wassermann, 1990: 44, grifos nossos).

As estratégias interativas da fase de análise provocam o educando a aperfeiçoar a comunicabilidade de suas idéias. Ele assume a responsabilidade de compreender o que fez e de descrever suas impressões e pensamentos. 0 emprego desses recursos respeita 0 aluno como ser dotado de competências, que tem algo importante a dizer, promovendo sua autoestima e autoconceito (perceber-se como integrante valorizado e reconhecer em si competências e saberes).

Quando a análise é bem sucedida, propicia as bases do novo jogo. A experiência renovada pode ter finalidades distintas. Pode atender desde 0 aprofundamento de conhecimentos e sofisticação das experiências na mesma área em que o jogo fora proposto anteriormente como pode enveredar por outras áreas curriculares, integrando-as à original.

Ao se perceber diante de uma experiência já conhecida e discutida, o educando reaviva interesse - agora enfocando outros ângulos - variáveis, procedimentos, hipóteses, etc. Assume o desenvolvimento dos conceitos tanto retrospectiva como prospectivamente, desde as primeiras descobertas até as novas indagações surgidas nas experimentações subseqüentes.

Seria impróprio designar quando devem ser finalizadas as experiências com um mesmo jogo. Em geral, não é o jogo que extingue possibilidades, mas são fatores atrelados às condições de tempo e à necessidade de atingir outros saberes curriculares, outras áreas de estudo.

Nossa perspectiva de formação aproxima-se da abordagem Jogo - Análise - Novo Jogo, 
embora não tenhamos nos respaldado em Wassermann ${ }^{15}$. De acordo com o que a autora propõe, há paralelos com os princípios vygotskianos que referenciaram nossa atuação como formadora, a serem deslindados na seqüência deste capítulo.

\section{2 - Abordagem vygotskiana para a formação lúdica de professores}

Vygotsky $(1987,1991)$ postula que as funções psicológicas superiores ${ }^{16}$ distinguem-se dos processos biológicos de desenvolvimento justamente porque são geneticamente socioculturais, dependem da relação mediada por formas culturais de instrumentos técnicos e sistemas semânticos, criados e compartilhados pelos membros da sociedade na qual o indivíduo está inserido e da qual é participante.

As funções psicológicas superiores de comportamento humano têm gênese na interação social, na participação do indivíduo em situações coletivas e mediadas pela linguagem. Assim, o princípio geral de desenvolvimento dessas funções é definido da seguinte forma:

Qualquer função psicológica superior foi externa [e] social antes de ser interna... Todas as funções no desenvolvimento cultural da criança aparecem duas vezes ou em dois planos... Aparece primeiro entre pessoas como uma categoria intermental [interpsicológica], e depois no interior da criança como uma categoria intramental [intrapsicológica]. Isso é igualmente verdadeiro para a atenção voluntária, para a memória lógica e para a formação de conceitos. (Vygotsky, 1987: 21)

Se textualmente Vygotsky reporta-se à criança, é inconteste que, em sua teoria, as funções psicológicas superiores continuem se desenvolvendo para além do término da infância.

Durante a evolução sócio-histórica, para se adaptar ao meio, o homem aprendeu a não depender de suas capacidades inatas, criando instrumentos para suprir suas necessidades e garantir sua sobrevivência. Nesse processo, inventou ferramentas e um ambiente social, alterando a si mesmo, o que suscitou formas superiores de comportamento que emergiram e se consolidaram intersubjetivamente.

Gradativamente, o ser humano aprende a usar racionalmente suas capacidades naturais... O ambiente se torna interiorizado [internalizado]; o comportamento torna-se social e cultural não só em seu conteúdo, mas também em seus mecanismos, em seus meios. (Vygotsky e Luria, 1996: 179, grifos dos autores)

\footnotetext{
15 Há uma grande semelhança entre nossa proposta de pesquisa empírica e a formulada por essa pesquisadora. Entretanto, nosso conhecimento sobre ela foi posterior à época de execução do projeto na escola.

${ }^{16}$ Tais funções dizem respeito a formas superiores de pensamento: atenção, percepção e memória mediadas e voluntárias, pensamento abstrato, generalizado e descontextualizado, comportamento intencional e autocontrolado (Vygotsky, 1987; Vygotsky \& Luria, 1996).
} 
A transformação das funções superiores do interpsicológico para o intrapsicológico não é um processo retilíneo, passivo. Pelo contrário, a pessoa atua sobre seu próprio desenvolvimento enquanto é agente de ação com o outro. A internalização não é cópia do plano intersubjetivo no indivíduo; é fruto de negociações, discordâncias, ação partilhada, etc, ao se formularem hipóteses para resolver situações concretas que o sujeito experiencia.

$\mathrm{Na}$ internalização, desenvolvimento e aprendizagem funcionam como uma unidade dialética. Embora sejam processos distintos, atuam em conjunto desde o nascimento. Assim, o aprendizado está estreitamente relacionado ao desenvolvimento das funções psicológicas superiores, determinadas por quatro características: a) estão sempre se reconfigurando dinâmica e constantemente, devido sua natureza sociocultural; b) auto-regulação voluntária da conduta, erigida do controle iniciado pelo entorno cultural; c) domínio consciente dos próprios processos psicológicos (metacognição) e d) o uso de signos como mediadores (Wertsch, 1988).

As funções psicológicas superiores instrumentalizam novas modalidades de pensamento, implicando mecanismos capazes de hierarquizar os conceitos simbolicamente, de relacionar um conceito a outros numa rede de generalizações e de operar com instrumentos mediadores descontextualizados, independentes dos contextos concretos em que foram originados.

De modo análogo ao desenvolvimento das funções superiores, Vygotsky explica que a capacidade de simbolizar, embora virtualmente possibilitada pela evolução biológica das estruturas cerebrais e do aparelho fonador, só entrou em operação a partir do desenvolvimento cultural, historicamente determinado pelas condições materiais de produção do trabalho coletivo nas sociedades humanas. "Essa função teria permitido um salto qualitativo no comportamento da espécie, submetendo os fatores biológicos a novas e melhores condições de operação" (Japiassu, 1999: 41). Assim, por exemplo, as emoções brutas teriam cedido lugar aos sentimentos, uma maneira forjada culturalmente para se relacionar, perceber e interpretar a realidade. Não se trata, porém, de substituição das formas elementares pelas superiores, mas de sobreposição do comportamento natural pelo histórico-cultural, em que aquele se modifica radicalmente pela estrutura constituída neste último.

A aprendizagem escolar é, nas teses vygotskianas sobre desenvolvimento humano, duplamente basilar. Ela interfere nos processos de constituição das formas superiores de pensamento e na apropriação dos instrumentos mediadores que circulam na sociedade. 0 professor reflexivo, em seu ofício, aprende continuamente, (re)elabora concepções, tece novas significações, reorganizando os conceitos (saberes) sobre sua própria prática. Esses 
conceitos...

não são entidades isoladas na mente do sujeito, mas estão organizados em algum tipo de todo estruturado, uma rede de significados, em que há relações entre os elementos. Essas redes articulam os conceitos entre si e podem ser consideradas teorias que o sujeito possui a respeito do mundo, sejam elas teorias científicas, sejam estruturas cognitivas do senso comum. Assim, os conceitos não devem ser vistos como conjuntos de propriedades, mas como parte da teoria em que estão embutidos. (Oliveira, 1999: 59)

O pensamento generalizante respalda-se na criação de uma rede ordenada voluntária e conscientemente, numa hierarquia de ligações subordinadas e supra-ordenadas de conceitos. Os diferentes graus de generalidade num sistema conceitual são sempre relativos. Pode-se figurar ${ }^{17}$ "jogo de tabuleiro" como um supraconceito que sistematiza relações entre diferentes tipos de jogos, como os de percurso (ludo) e de estratégia (xadrez). Simultaneamente, está subordinado a outras categorias conceituais - em planos mais genéricos ("jogo de mesa", "atividade lúdica") - e guarda equivalência na escala conceitual ao ser comparado com outros conceitos como, por exemplo, "jogo de destreza (ou perícia)", que qualifica o boliche e o bilhar.

Os conceitos caracterizam-se pela capacidade de discriminar atributos isolados, ou seja, abstrair propriedades, elementos, sub-relações que integram a experiência concreta. Por sua vez, essas sínteses abstratas são descontextualizadas, ou seja, podem ser utilizadas de modo instrumental em novos contextos.

A conceituação é um aspecto central na prática lúdica de educação. Através dela, o professor abstrai e generaliza saberes que the permitem consolidar experiências educativas com o jogo, reconhecendo como e para que o faz. Como explica Vygotsky (1991: 169), "um conceito surge quando uma série de atributos que foram abstraídos se sintetizam novamente e quando a síntese abstrata daí resultante se converte na forma fundamental de pensamento".

Os conceitos se alicerçam nas estruturas de generalização e de abstração. Tal como a respiração é um movimento inseparável de expirar e inspirar, nos conceitos é igualmente importante unir e separar, ou seja, generalizar e abstrair. Da combinação entre análise e síntese constitui-se a abstração generalizante, tornando possível aos conceitos romperem a barreira do contexto, deslocarem-se do geral ao particular e do particular ao geral, formando

${ }^{17}$ Definir e classificar jogos não cabe aos nossos propósitos, embora seja útil para ilustrarmos como se organiza uma rede de generalidades conceitual. Tratando-se de jogo, os exemplos indicados podem receber outras categorização, pois jogo é "um conceito com contornos imprecisos" (Wittgeinstein, 1975), cuja definição se estabelece por parentescos entre múltiplos significados, compondo uma árvore genealógica que inclui várias possibilidades de classificação. 
relações novas e, principalmente, orientando a atuação no mundo.

A conceituação não é um movimento em pirâmide, verticalizado, entre um conceito geral e outro, particular. Movimenta-se em duplo sentido, como um túnel escavado para lados opostos simultaneamente, alargando o sentido abstrato ao mesmo tempo em que torna o conceito mais factível de aplicação concreta.

Em seu processo de aprendizagem, o indivíduo parte das próprias generalizações e significados, determinados por um processo sócio-histórico. Não abandona os conceitos construídos, mas entra num novo caminho acompanhado deles, de análise intelectual, comparação, unificação e estabelecimento de relações lógicas. Raciocina, seguindo explicações recebidas e experiências vividas, e reconstrói internamente operações lógicas (novas para ele), de transição de uma generalização para outras. Na pessoa, os conceitos...

construídos ao longo de sua vida no contexto de seu ambiente social... são agora deslocados para um novo processo, para nova relação especialmente cognitiva com o mundo, e assim... são transformados, e sua estrutura muda. Durante o desenvolvimento da consciência..., o entendimento das bases de um sistema cientifico de conceitos assume agora a direção do processo. (Leontiev \& Luria, 1968 apud Vygotsky, 1994: 147)

Quanto mais aprisionado aos fenômenos e objetos do real, maior é a concretude de conceitos, análise da experiência, observação de suas particularidades e generalização para outros contextos. Quanto mais abstrato e maior o grau de generalidade, mais consciente e voluntário é o ato mental para significar um dado fenômeno da realidade, inclusive para antecipá-lo, ou seja, pensar sobre algo que ainda não foi experimentado.

É, pois, a presença ou ausência de um sistema que distingue a consciência autônoma. A elaboração de um sistema generalizável é um longo caminho de distanciamento da experiência concreta e da percepção imediata, exigindo subordinações e supra-ordenações, partindo mas superando o conhecimento tácito.

Por ser essencialmente verbal, todo conceito é determinado pela capacidade de significar, operando conscientemente de modo descentralizado, generalizante e abstrato. Constitui-se de uma combinação original das funções psicológicas superiores, em que a linguagem intervém para orientar deliberadamente a análise e a simbolização da realidade.

Os conceitos são gerados pela deliberada e sistemática verbalização (como ocorre ao se discutir sobre uma experiência lúdica realizada). Resultam do processo de aquisição de um sistema de conhecimento mediado (sistemas hierarquicamente ordenados), em que predomina o pensamento verbal. Segundo uma relação de inclusão e abrangência, estão organizados hierarquicamente num sistema. Surgem das relações abstratas interconceituais, distanciados dos referentes que os engendraram. 
Os conceitos não existem isoladamente, estão dinamicamente vinculados uns aos outros, ou seja, eles "...não ficam guardados na mente da pessoa como ervilhas em um saco, sem qualquer vínculo que as una" (Vygotsky, 1991: 224). As relações estabelecidas entre os conceitos são ordenadas de acordo com graus variáveis de generalidade. Isso implica reconhecer que todo conceito é um ato de generalização, embora haja uma escala de desenvolvimento entre graus de generalidade.

A multiplicidade de relações interconceituais resulta de um sistema ordenado com diferentes graus de generalidade. Assim, um conceito equivale a muitos outros. As mudanças de níveis de generalidade dentro de um sistema conceitual dependem, por sua vez, da formação de novos conceitos que possam reordenar os elos estruturais.

Vejamos um exemplo esquemático. A transferência de um objeto da estrutura A para a estrutura $B$ exige a passagem para um plano de maior generalidade, em que se encontra um conceito $C$ supra-ordenado regendo os anteriores. De início, tem-se que a multiplicação é a soma repetida de um mesmo número $(A)$ e a divisão é a subtração repetida de um mesmo número (B). Porém, somente por meio da noção matemática de reciprocidade (C) é que as relações de generalidade entre as quatro operações matemáticas podem ser estabelecidas, tornando viável compreender equivalências tais como: a multiplicação está para a adição assim como a divisão está para a subtração, ou que a subtração é o oposto da adição assim como a divisão é o oposto da multiplicação.

Em paralelo, tomemos como exemplo a configuração das regras de jogo. Imaginemos que um professor pretenda fundamentar a aprendizagem de um conceito escolar numa atividade ludo-educativa. Seria inócuo lhe propor que conhecesse uma infinidade de jogos regrados a ponto de ser capaz de selecionar, dentre eles, o mais apropriado ao objetivo de ensino.

Como esse problema poderia ser resolvido? Suponha que seus alunos tenham experienciado com sucesso um jogo de percurso em que, dentre as regras, foi decisiva a construção de legendas para orientar as ações dos peões (peças que representam cada jogador). A noção de legenda é subordinada à de objetos (simbólicos), cuja característica essencial é fornecer instruções. Ou seja, legenda, ficha de informações, representação iconográfica e esquema são mecanismos mediadores que instruem o que fazer durante 0 jogo. Ao transferir a noção de legenda para outros contextos, o professor não o faz de modo direto (ter como regra que todo jogo tenha legenda), mas sim através de uma rede de generalidades.

$\mathrm{Na}$ formação ludo-educativa, tal rede de generalidades exerce um papel fundamental na transformação reflexiva da prática pedagógica, embasando escolha do jogo, configuração de 
regras e organização do cenário lúdico e educativo, decisões estas que prescindem de um sistema de generalidades capaz de se ajustar às múltiplas necessidades educativas dos educandos e à diversidade de objetos de conhecimento escolar.

Num sistema análogo às latitudes e longitudes do globo terrestre, um conceito se insere em dois contínuos simultaneamente. A latitude localiza o conteúdo objetivo do conceito. Longitudinalmente estão representados os atos de pensamento necessários à apreensão daquele conteúdo. Da intersecção dessas coordenadas resulta a medida de generalidade de um conceito com os demais (equivalências, supra-ordenações e subordinações).

Dialeticamente, esta estrutura de generalidade retorna à experiência concreta, auxiliando a exercê-la e avaliá-la, bem como promovendo "ascensão do desenvolvimento mental para níveis mais elevados (Vygotsky, 1987: 236).

Com isso, a consciência individual torna-se deliberada, num grau crescente de autonomia na apropriação e utilização do saber historicamente construído. A internalização de novos modos de funcionamento mental instrumentaliza a metacognição: a consciência de si mesmo (saber que sabe) e dos próprios processos mentais (saber como e por que sabe).

Dominar as regras e as peças do jogo de xadrez significa investigar as próprias estratégias cognitivas, compará-las com as utilizadas pelo adversário num processo mental consciente e volitivo. A isso se refere o exemplo de Vygotsky em que, fazendo um nó, a pessoa está consciente de sua conduta, mesmo que não saiba explicar como fez, dado que toda sua atenção estava dirigida ao nó, e não aos próprios movimentos. A plena consciência depende tanto do saber fazer como da percepção mediada da atividade mental. Na verdade, antes de ser um ato a-consciente (não consciente), os exemplos do nó e do jogo de xadrez demonstram a existência de diferentes graus de consciência ou, mais precisamente, graus de generalidade. "A tomada de consciência se fundamenta na generalização dos próprios processos psicológicos... É precisamente nesse processo que a aprendizagem escolar desempenha um papel decisivo" (Vygotsky, 1991: 213), priorizando a organização sistemática e hierárquica de percepções generalizantes.

Metacognição é a capacidade de pensar, não apenas sobre os próprios pensamentos e processos mentais, mas também sobre o pensamento dos outros. Ela desenvolve habilidades de auto-regulação e gerenciamento, necessárias na avaliação do raciocício, identificando incongruências e possibilitando o redimensionamento de modos de pensar e agir.

A consciência reflexiva e o controle deliberado - que caracterizam as funções psicológicas superiores - correspondem ao processo de apropriação de conceitos, de indiferenciação para diferenciação, de concretude para abstração, de centramento para descentramento.

O conceito de Zona de Desenvolvimento Proximal (ZDP), ao transcender as formulações 
que priorizam o nível de desenvolvimento real, implica uma nova e original forma de compreender os processos de desenvolvimento e aprendizagem. Concebida numa perspectiva dialógica, dialética, multidirecional e não-etnocêntrica, a ZDP resulta das interações mediadas culturalmente, através das quais se instauram áreas potenciais de desenvolvimento.

Vygotsky concebe ZDP como o espaço em que se deve explicitamente atuar, entre o nível de desenvolvimento real - determinado pela capacidade de solução de problemas de forma independente - e o nível de desenvolvimento potencial - em que se encontram as funções psicológicas em processo de amadurecimento, potencialmente emergentes, mas ainda não suficientemente consolidadas. ZDP supõe ação em parceria, com auxílio de outra pessoa mais experiente que proponha desafios, questione, forneça pistas acerca das soluções possíveis, etc (Vygotsky, 1987, 1991).

“A ZDP é o lugar onde, graças aos suportes e à ajuda dos outros, pode desencadear-se 0 processo de construção, modificação, enriquecimento e diversificação dos esquemas de conhecimento definidos para a aprendizagem escolar" (Baquero, 2001: 128). É um espaço dinâmico de desenvolvimento, não é qualidade do indivíduo ou de sua atuação específica.

Assim sendo, na ZDP, competências e habilidades em construção são postas em ação, primeiramente, num cenário interpsicológico para se tornarem internalizadas pelo indivíduo, intrapsicológicas.

Um aspecto essencial do aprendizado é o fato de ele criar zonas de desenvolvimento proximal; ou seja,... desperta vários processos internos de desenvolvimento, que são capazes de operar somente [na interação entre] pessoas em seu ambiente e quando em cooperação com seus companheiros. Uma vez internalizados, esses processos tornam-se parte das aquisições do desenvolvimento independente. (Vygotsky, 1994: 101)

Podemos falar em múltiplas zonas de desenvolvimento, seja em relação a uma pessoa ou a um grupo, dependendo não apenas dos conhecimentos e competências em jogo, mas também do que a tarefa exige e de como está emoldurada pela interação.

A situação lúdica favorece a criação de ZDP. Ao jogar, o aluno se propõe a enfrentar um desafio que - configurado segundo os objetivos e regras do jogo - auto-regula sua conduta e seu pensamento, o que coincide com os aspectos supra citados acerca das decisões envolvendo ensino. Evidentemente, toda a organização do espaço lúdico e as mediações do educador se integram ao jogo visando à aprendizagem, que ocorre durante e após sua execução.

Ao propor que, através do jogo, a criança desenvolve funções embrionárias e controla seu comportamento num nível maior do que o habitual, Vygotsky estabelece um paralelo 
entre ludicidade e aprendizagem escolar, já que ambas funcionam como espaço onde ocorre desenvolvimento. Em outras palavras, a situação lúdica, tal como a de aprendizagem escolar, é capaz de criar campos de experimentação de habilidades, modos de operar mentalmente e agir no mundo que desafiam o conhecimento já internalizado, gerando zonas de desenvolvimento proximal.

As idéias vygotskianas encerram um dilema aos nossos propósitos, visto que 0 jogo ${ }^{18}$ é a atividade principal da criança pré-escolar, mas deixa de sê-lo para a escolar. Mesmo creditando a ele um papel crucial para o desenvolvimento, o fato de ter limitado seu poder de ação ao período imediatamente antecedente àquele para o qual norteamos nosso estudo, provoca a necessidade de ajustes para o tipo de atividade característico da etapa escolar, qual seja a experiência com o aprendizado formal.

O ensino lúdico depende de o educador desenvolver conhecimentos específicos sobre jogo, notadamente a partir da construção de um sistema conceitual. 0 pensamento conceitual engendra um raciocínio lógico, abstrato, descontextualizado, generalizado e metacognitivo capaz de sustentar a atividade consciente e autônoma do indivíduo sobre si mesmo e em sua relação com o mundo. Nesse sentido, fundamentar práticas pedagógicas na ludicidade significa um saber-fazer reflexivo, em que o jogo seja constituinte de zonas de desenvolvimento proximal, mediando a aprendizagem.

Nosso intuito não é formar educadores pela brincadeira, mas tê-la como parâmetro na construção de uma prática lúdica de ensino. O processo de ensino-aprendizagem respaldado pelo exercício da ludicidade promove o desenvolvimento potencial do educando, pois nela se instaura um campo de aprendizagem propício à formação de imagens, à conduta autoregulada, à criação de soluções e aos avanços nos processos de significação. Na brincadeira são empreendidas ações coordenadas e sistematizadas, dirigidas a um fim e, por isso, antecipatórias, contribuindo com o pensamento conceitual. A força motriz da ludicidade, 0 que a faz ser tão importante no complexo processo de apropriação de conhecimentos, é a combinação paradoxal de liberdade e controle. Ao mesmo tempo em que os horizontes se ampliam segundo os rumos da imaginação, o cenário lúdico se molda segundo os limites que os próprios jogadores se impõem, subordinando-se mutuamente às regras que conduzem a atividade lúdica.

\footnotetext{
${ }^{18}$ Sem nos determos em discutir a terminologia, optamos pelo termo jogo como atividade lúdica em geral. A tradução do livro de Elkonin emprega jogo, enquanto nos textos em português de Vygotsky aparece o termo brinquedo. Ambos, porém, referem-se à atividade lúdica e, mais especificamente, àquela que envolve protagonização de papéis, também conhecida como faz-de-conta ou jogo simbólico.
} 


\section{3 - Princípios da ludo-educação}

A relação entre jogo e aprendizagem tem um estatuto teórico proeminente na proposição histórico-cultural do desenvolvimento, não porque exista uma produção extensa sobre o assunto, mas porque jogo tem explícita relação com desenvolvimento potencial. Além disso, aborda um aspecto de grande relevo na configuração de propostas ludo-educativas de formação de professores: o desenvolvimento da imaginação, indicando que tanto no desenvolvimento infantil quanto no do adulto há fortes laços entre processos imaginários e aprendizagem, pois a imaginação caracteriza-se como sistema integrado das funções psicológicas superiores, tornando-nos capazes de acessar, interpretar, significar e modificar a realidade e a nós mesmos.

A primeira característica definidora do brincar é a criação de situação imaginária. De acordo com Vygotsky, essa não é uma idéia nova, mas sempre foi vista como característica de um determinado tipo de brincadeira.

Em todo jogo há uma situação imaginária por meio da qual o indivíduo alcança uma definição funcional de conceitos e objetos. Por isso, "a criação de uma situação imaginária não é algo fortuito na vida da criança; pelo contrário, é a primeira manifestação da emancipação da pessoa em relação às restrições situacionais" (Vygotsky, 1994: 113).

No entanto, o simbolismo lúdico não é equiparável ao que concerne aos conceitos científicos. Caracterizar o brincar como simbólico significa reconhecer o vínculo existente entre a situação imaginária e a motivação para brincar.

A segunda característica definidora é que todo jogo é envolto num conjunto de regras, com diferenças de predominância que acompanham o desenvolvimento. "A situação imaginária de qualquer forma de brinquedo já contém regras de comportamento, embora possa não ser um jogo com regras formais estabelecidas a priori." (idem: 108)

A idéia mais importante para se entender a relação entre regras e imaginário no jogo é que ambos o compõem, havendo, no entanto, uma diferença de predominância no decurso do desenvolvimento. De início, predominam os jogos em que a situação imaginária é explícita e as regras, seguindo as representações simbólicas, são implícitas. Posteriormente, essa relação se inverte: as regras são explícitas e a situação imaginária está oculta.

A partir dessas duas características definidoras do jogo, Elkonin investigou de que maneira elas o tornam criador de zonas de desenvolvimento proximal. Pelo fato de resultar de uma combinação entre regras e situação ficcional (imaginária), a atividade lúdica promove: evolução no campo das motivações e necessidades, superação do egocentrismo cognitivo, evolução das ações mentais e evolução da conduta arbitrada. 
Dada a relevância estrutural desses quatro elementos inerentes ao jogo, vejamos mais detalhadamente cada um deles, segundo a proposição de Elkonin. É preciso levar em conta que o interesse do autor estava centrado no desenvolvimento infantil. Para nós, suas idéias são importantes na elaboração dos princípios que regem a formação de professores. Portanto, a explicitação desses aspectos implica diretamente os objetivos almejados pelo projeto formativo, devido ao fato de que somente se o educador compreende as características implícitas à atividade lúdica e as relações desta com a educação pode vir a incorporá-la reflexiva e autonomamente em sua prática.

Os estudos de Elkonin dirigiram-se à primeira infância, enquanto em nossa pesquisa a formação está orientada a professoras de crianças maiores, o que relativiza as características definidoras de jogo, determinando que, ao trazer as contribuições desse autor, selecionamos os aspectos que mais se conformam à idade escolar.

\section{1 - evolução no campo das motivações e necessidades}

A obviedade do fato de que só joga quem quer, não sendo jogo se imposto, deixa subliminar a complexa relação entre atividade lúdica e motivação. Vygotsky já apontara que a mudança na esfera motivacional (volitiva) sofre influência decisiva do jogo ao longo do desenvolvimento.

Brincar exige agir contra o impulso imediato, "o maior autocontrole da criança ocorre na situação de brinquedo" (Vygotsky, 1994: 113). O grau máximo da volição decorre do desejo da criança em se sujeitar às regras.

Na mesma diretriz, completa Elkonin (1998: 406): “...é justamente no jogo que se dá a transição das razões com forma de desejos imediatos, impregnados de emotividade préconsciente, para as razões com forma de desígnios sintéticos, próximas da consciência".

O jogo só existe por seu caráter funcional, como meio pelo qual são suprimidas necessidades e desejos irrealizáveis através de outras esferas de atividade. Porém, jogando, a criança também transcende tendências imediatas, enraizadas em motivações mais biológicas e primitivas, para alcançar o nível do desejo de seguir as regras sociais e atuar espelhando-se na realidade. Inicia imitando uma ou outra ação isolada, dirigida a um objeto, mas representativa do meio sociocultural que a circunda (fazer um boneco 'dormir'), até formular um conjunto de ações inter-relacionadas que seguem a representação lógica de papéis sociais e que podem prescindir de objetos (fazer-de-conta, com foco central em mímicas e verbalizações). Claro está que imitar a realidade não significa copiá-la integralmente, mas interpretá-la adicionando, unindo, selecionando elementos numa nova e original criação. 
É importante a escolha de um jogo e dos meios adequados para oferecê-lo à criança, particularmente quando visamos retirar dele o maior proveito educativo. Advém disso a necessidade de transferir à escola as mesmas motivações que a criança encontra para jogar fora desse espaço. Utilizar um jogo já familiar à criança ao invés de lhe propor, em primeira mão, algo completamente novo; instruir inicialmente sobre duas ou três regras simples para, depois de implementada a situação lúdica, fornecer outras mais sofisticadas; garantir sempre certa liberdade aos alunos na condução da atividade e, sobretudo, respeitar os momentos de negação e oposição, buscando conhecer suas origens junto à criança, são aspectos fundamentais.

O fato de a criança se negar a jogar, antes de ser um capricho, pode significar insegurança, temor frente ao insucesso (não saber jogar, perder uma partida), desconforto com a situação de exposição, enfim, questões com as quais se aprende a lidar no jogo e na vida. O fascínio do jogo em adição ao ajuste dos auxílios de professor e demais colegas colaboram de maneira decisiva para a criança enfrentar os sentidos originários de sua própria recusa.

Noutras ocasiões, se o jogo não é imposto, a direção que os alunos the imprimem pode ser diversa daquela planejada pelo professor. Se, por exemplo, lidando com qualidades de substantivos, o jogo de dominó é transformado pelos alunos em jogo da memória, o conhecimento que está se engendrando - a adjetivação - permanece o mesmo. Isso não impede que as aprendizagens almejadas se percam; pelo contrário, as alterações realizadas pelas crianças aguçam seu interesse pelo desafio. Demonstram, ao mesmo tempo, habilidades cognitivas que não se apresentariam caso se mantivessem fiéis à proposta inicial, pois não é só uma questão de 'troca' entre um jogo e outro.

\section{2 - superação do egocentrismo cognitivo}

Segundo Elkonin (1998), o jogo cumpre um papel fundamental no desenvolvimento do psiquismo por ser uma atividade que proporciona a superação do egocentrismo cognitivo, refletindo-se na capacidade de descentralizar o pensamento para reconhecer outros pontos de vista e coordená-los num sistema de operações composto de ações inter-relacionadas.

o jogo se apresenta como uma atividade em que se opera o 'descentramento' cognoscitivo e emocional da criança. Vemos aí a enorme importância que o jogo tem para o desenvolvimento intelectual. E não se trata apenas de que no jogo se formam ou se desenvolvem operações intelectuais soltas, mas de que muda radicalmente a posição da criança em face do mundo circundante e forma-se o mecanismo próprio da possível mudança de posições e coordenação do critério de um com os outros critérios possíveis. (p. 413) 
Em seus estudos sobre o egocentrismo cognitivo, Nedospásova (1972 apud Elkonin, 1998: 406-413) faz uso de um experimento ${ }^{19}$ para investigar de que maneira a brincadeira interativa promove a descentração do pensamento.

Mediante o jogo protagonizado com uso de objeto lúdico (três bonecos representando irmãos) e com perguntas orientadoras propostas pelo investigador, a experiência compõe-se de duas fases em que três crianças são instigadas a identificar a quem pertencem os bonecos. De uma fase a outra, altera-se o tipo de intervenção do adulto. Na primeira, a atenção da criança dirige-se ao próprio boneco para, depois, referir-se aos bonecos-irmãos dos companheiros de jogo.

Nedospásova conclui que a situação de jogo potencializa a superação do egocentrismo cognitivo ao distanciar a criança de sua própria realidade e implicar na coordenação de suas ações em função dos diferentes papéis, seu e dos companheiros. Enquanto a mediação dos bonecos contribui para a representação cênica de cada papel, as intervenções do investigador orientam a modificação dos significados atribuídos aos objetos lúdicos.

Da comparação entre as duas fases do experimento, evidencia-se uma constatação de suma importância para o ensino lúdico: não é suficiente inserir o jogo em sala de aula; é fundamental organizar o cenário ludo-educativo e estabelecer modalidades interativas que extraiam os melhores proveitos da brincadeira para o desenvolvimento cognitivo.

\section{3 - evolução das ações mentais}

Aludindo ao papel da linguagem na transição das ações lúdicas do plano concreto para o plano mental, Elkonin ressalta que a função mediadora da fala transforma o ato lúdico em operações internalizadas de pensamento.

Baseada na linguagem, a atividade lúdica adquire a capacidade de desenvolver os dois processos inerentes ao sistema simbólico (signos): a descontextualização e a generalização.

O pensamento generalizante é constituído por uma rede ordenada voluntária e conscientemente, numa hierarquia de relações subordinadas e supra-ordenadas de conhecimento. A generalização é essencial na construção de sínteses. Numa brincadeira de faz-de-conta, tendo que representar um determinado personagem, a criança se orienta pela reunião de atributos que o identificam, mesmo quando não tem plena consciência dessa ação mental.

A descontextualização caracteriza-se pela capacidade de discriminar e isolar informações,

${ }^{19} \mathrm{O}$ experimento dos 'três irmãos' foi criado por Binet e serviu para Piaget elaborar a tese de que o egocentrismo cognitivo reflete a incapacidade da criança operar logicamente, impedindo-a de se colocar no lugar do outro ou reconhecer pontos de vista alheios. 
ou seja, abstrair propriedades, fenômenos, idéias que integram a experiência concreta a fim de utilizá-las de modo instrumental em novos contextos. Rompendo a barreira contextual, o conhecimento pode se deslocar do geral ao particular e vice-versa, estabelecendo novas relações e se combinando com outros. Assim, regras aprendidas num jogo podem ser apropriadas e embasar novos jogos da mesma forma que um conceito aprendido num contexto específico pode ser descontextualizado, ou seja, aplicado em novas situações de aprendizagem.

Numa brincadeira de faz-de-conta, ao representar um determinado personagem, a criança se orienta pela reunião de atributos que o identificam, mesmo quando não tem plena consciência dessa ação mental.

De acordo com Elkonin, no jogo esses processos se constituem ao longo de quatro níveis de desenvolvimento, determinados sobretudo pela quantidade de oportunidades de vivenciar atividades lúdicas.

Quando a brincadeira aparece na vida da criança, a ação é rudimentar e isolada, dirigida pelo objeto lúdico. Nesse nível, um fragmento de ações da realidade é imitado numa única ação, repetida sucessivamente.

No segundo nível, o significado do brincar ainda é aprisionado ao objeto, mas o repertório de ações se amplia, formando uma coleção de atos que, embora não constitua uma rede coordenada e hierarquizada logicamente, fomenta o pensamento generalizante.

No terceiro nível, o papel assumido pelo objeto é cedido à representação, e as ações se desligam da percepção imediata, tornando-se descontextualizadas. A linguagem assume a função dos objetos, que podem deixar de existir concretamente. Os papéis se delineiam segundo uma cadeia seqüenciada de ações, cuja lógica espelha as regras de conduta da realidade cotidiana vivenciada pela criança.

Finalmente, a capacidade de construir temáticas permite ampliar, variar, encadear e definir as ações correspondentes às representações. 0 jogo se torna mais complexo. Os papéis e as relações entre os jogadores já estão bem evidentes, o que facilita a subordinação às regras. Por sua vez, o sistema de regras é fundamentalmente simbólico e determinado por generalizações e descontextualizações. A recusa por ações não condizentes com o jogo não decorre da imposição de desejos imediatos, nem "pela simples invocação da realidade existente, mas pela indicação da racionalidade das regras" (id., p.299).

Os níveis de evolução do brincar demonstram transformações do pensamento. A utilidade da brincadeira está exatamente em sua aparente inutilidade, pois possibilita exercitar, criar, inventar, experienciar numa situação específica, em que o real é reconstruído mediante regras elaboradas pelos próprios envolvidos. o jogo é um campo de experimentação, e a 
criança, tal qual o cientista, busca compreender a realidade, formulando hipóteses, testandoas e, assim, aprendendo.

\section{4 - evolução da conduta arbitrada}

$\mathrm{Na}$ medida em que a situação imaginária é enriquecida tanto pela complexidade de atribuição de sentidos como pela variabilidade e multiplicidade de papéis em cena, solidificase a atitude pautada em regras. Regras tomadas de empréstimo da realidade são apropriadas pelo jogo, tornam-se arbitrárias segundo os motivos lúdicos.

Todo o processo de subordinação às regras tem nos jogos protagonizados (de papéis) uma fonte de ampliação do universo de regras implícitas que se revelam progressivamente e, em contrapartida, a situação imaginária torna-se latente. As regras, ao se tornarem patentes, tomam o lugar de controle de conduta lúdica. Nesse percurso, o embate entre satisfação de desejos imediatos e subordinação às regras determina três estágios da autoregulação do comportamento.

No primeiro, a criança não é capaz de cumprir as regras simplesmente porque as ignora. Sem reconhecê-las, é inteiramente dirigida por seus desejos impulsivos. "Não há uma clara luta entre as regras e o desejo" ( $i d .$, p.247). No segundo, já se manifesta a consciência de que sua ação no jogo é determinada por algumas condições, resultantes do acordo estabelecido entre os participantes, mas a realização do desejo imediato é oposta ao subordinar-se às regras. É um momento de transição, em que a relação estabelecida com os companheiros do jogo passa a ter forte influência sobre a decisão que venha tomar. Havendo a mediação de um adulto que seja investido de autoridade, tende a prevalecer o respeito à regra. No terceiro, as regras passam a condicionar a própria manutenção do jogo, independente de controle externo. A criança sente prazer ao respeitá-las, postergando ou alterando a realização de seus desejos.

Uma regra de jogo só tem valor se for aceita pelos jogadores... (Ela) permite que se crie uma outra situação que libera dos limites do real... Sem riscos, a criança pode inventar, criar, experimentar nesse universo (em que) estão minimizadas as conseqüências de seus próprios atos. (Brougère, 1998: 192)

A brincadeira se mantém porque todos estão de acordo, unidos pelo desejo de brincar. A regra é base para o jogo e, a partir dela, constrói-se um mundo demarcado por experimentação e imaginação.

Estes princípios circunscrevem a idéia central sobre as relações entre jogo e educação. Consideramos o jogo, a partir de suas características formuladas pela visão histórico-cultural, 
um mediador de expressivo potencial para a educação formal, tanto para o trabalho junto ao corpo discente como para o da formação de professores.

Para a criança, o jogo impõe uma situação-problema que provoca desenvolvimento da conduta regrada, superação do egocentrismo cognitivo, mudanças volitivas e motivacionais e, especialmente, desenvolvimento de ações mentais direcionado às mudanças no campo de criação, elaboração e reconstrução de significados acerca das experiências e perspectivas. As quatro qualidades acima, referenciadas nas conclusões de Elkonin sobre a atividade lúdica, reportam-se aos processos mentais de metacognição, descontextualização e generalização.

No adulto - particularmente no caso de professores - a formação pessoal e profissional já consolidou diferentes conhecimentos, crenças e atitudes valorativas acerca especificamente da docência e do processo educativo, além de uma vasta rede de conhecimentos sobre o brincar.

Independente da idade, o valor do jogo para a aprendizagem está na experimentação, por meio da qual quem joga atribui sentidos, compreendendo e integrando os conhecimentos trazidos pelo jogo aos saberes já conhecidos, internalizados. Para Elkonin, no jogo "a profundidade de aprendizagem é muito superior, pois não há aprendizagem somente pelo que é transmitido por outra pessoa, mas pelo que se experiencia" (1998: 74).

\section{4 - Educação Lúdica no Ensino Fundamental}

Jogos e outras atividades lúdicas fazem parte da história da humanidade. São conhecidos os exemplos de épocas antecedentes à criação do conceito de infância (Ariès, 1981), quando adultos e crianças misturavam-se, interagindo livremente como co-participantes de brincadeiras.

Independente de época, sociedade, circunstância, 'lúdico' está diretamente associado a envolvimento, interesse implícito à situação de jogo, mesmo quando a diversão é superada por desprazer, como ocorre nos casos em que se perde uma competição ou nas tentativas frustradas que se desenrolam até que o objetivo do jogo seja alcançado. Vygotsky é um dos autores que alertam para o fato de que não é o prazer uma característica suficiente para definir jogo, justamente porque pode haver desprazer; porém, o envolvimento se mantém. Em decorrência desse envolvimento, há um consenso em ressaltar o jogo como situação de aprendizagem. A questão que nos parece ainda muito nebulosa é como se dá essa aprendizagem e de que forma pode se coadunar com a aprendizagem do ensino formal. Seguramente, deve-se levar em conta que a aprendizagem não pode estar deslocada do envolvimento com o próprio jogo, sem haver separação entre aprendizagem, jogo, trabalho e lazer. 
A dicotomia trabalho - jogo existe dentro e fora do contexto escolar. A crença de que para ser sério, competente ou importante, o trabalho não pode ser divertido, excitante, estimulante, prenhe de emoções associadas aos momentos de lazer resulta um encrudecimento do relacionamento afetivo com o trabalho, ambiente, colegas, perspectivas de atuação, pressões, e assim por diante.

Essa crença tem origens históricas, e não pode ser ignorada quando pensamos em nos dirigir à profissão de educador com a pretensão de instigá-lo a ter o jogo como referência para seu trabalho.

Não é exclusiva ao mundo escolar - apesar de ser constante - a dificuldade do adulto se abster das situações moldadas, conformadas, estruturadas, com um plano de metas cuja execução se dá de forma mais ou menos semelhante. Nesse sentido, muitas escolas, ainda hoje, não são tão diferentes de épocas passadas, constituindo-se de um programa rígido a ser cumprido e tendo o professor como figura central do processo, transmitindo saberes a alunos que devem passivamente obedecer a normas institucionais e reproduzir os conhecimentos que Ihes são despejados dia após dia. Por outro lado, há casos em que o jogo está completamente integrado ao ambiente educativo ${ }^{20}$. Não por acaso, as condições de trabalho nesses locais são igualmente distintas, havendo melhor relação professor/alunos em sala de aula; forte apoio de equipe pedagógica; contato com outros centros de estudo e horários garantidos para o corpo docente planificar seu programa de aulas, avaliar, trocar informações e estudar.

O propósito central do projeto de formação é abordar a atuação lúdica com o conhecimento como alternativa para a aprendizagem escolar. Embora não seja uma idéia nova na história da educação, na atualidade é mais aceito e divulgado o entendimento de aprendizagem como apropriação, num processo dinâmico de investigação sobre os objetos de conhecimento que, tornados próprios pelo aprendiz, fazem sentido para sua vida, para seu 'ser no mundo'. Por isso, a atividade lúdica, constitutiva do próprio homem, pode e deve ser privilegiada como atividade educativa. Afinal, em 1926, em seu Psicologia Pedagógica, já denunciava Vygotsky:

O maior pecado da velha escola consistia em que nenhum dos seus participantes sabia responder por que se estudam geografia e história, matemática e literatura. Engana-se quem pensa que a velha escola fornecia poucos conhecimentos. Ao contrário, freqüentemente ela comunicava um volume incomum de conhecimentos... Mas era sempre e

${ }^{20}$ Esta descrição é referenciada num exemplo de nosso conhecimento, uma escola da rede municipal de São Paulo que, por meio de convênio com a Escola da Vila, veio a instaurar uma série de mudanças no decorrer dos últimos três anos, apresentando, atualmente, as características citadas acima, embora os profissionais que nela trabalhem reconheçam uma série de entraves e necessidades por serem superados e resolvidos. 
apenas um tesouro no deserto, uma riqueza da qual ninguém conseguia fazer o devido uso porque a diretriz básica dos seus conhecimentos estava à margem da vida... esses conhecimentos não estavam em condições de satisfazer às mais simples demandas vitais do aluno mais comum e modesto.

Cada um se lembra por experiência própria que quase a única aplicação que conseguiu fazer dos conhecimentos adquiridos na escola foi ter dado uma resposta mais ou menos exata nas provas finais, e o conhecimento de geografia ainda não ajudou ninguém a orientar-se no mundo e ampliar o círculo de impressões em uma viagem...

Por tudo isso, a principal reivindicação pedagógica vem a ser de que (...) o educador saiba sempre e com precisão a orientação em que deve agir a reação a ser estabelecida. (2001: 171)

A proposta da ludo-educação pode se tornar um meio para o professor se questionar, modificar e criar novas maneiras de pensar e de agir em relação aos conhecimentos que pretende ensinar. Para lidar com esses saberes e se apropriar deles, há necessariamente um processo metacognitivo pelo qual se avalia o que se sabe e o que não se sabe, os meios já conhecidos e os novos - que podem advir por meio de situações específicas (aprendizagem formal em situação lúdica, por exemplo) - e se levantam possibilidades para compreender, utilizar, experimentar e observar resultados em relação às conceituações.

Balizamos nosso entendimento de educação lúdica (ludo-educação) nos seguintes princípios:

$\stackrel{4}{4}$ Em circunstâncias ludo-educativas, a luta travada entre subordinação às regras e satisfação de desejos e necessidades imediatas determina a criação de um espaço para aprendizagem, exercício de habilidades e competências potenciais e avaliação metacognitiva das próprias condutas.

4. A permeabilidade e influência mútua entre as esferas da realidade e da imaginação são modos de operar mentalmente. Esta reciprocidade desempenha papel crucial na internalização de modos de conceber e atuar no mundo, no aprofundando de redes interconceituais, na ampliação do potencial criativo e na capacidade de representar simbolicamente.

$\stackrel{4}{4}$ A realidade imaginária se apóia no real para elaborar hipóteses e solucionar problemas por meio da imaginação, materializada em criações, mas é paradoxalmente libertadora de qualquer vínculo com os limites impostos pelo real.

$\stackrel{\leftrightarrow}{\leftrightarrow}$ A situação de jogo é necessariamente desafiante. Elicia a ação simbólica para transmutar e recriar o real, determinando a subordinação dos objetos e ações aos significados que se propõe implicar na situação lúdica. Assim sendo, a criação de uma situação imaginária coordena mudanças no campo simbólico: o significado não é mais 
um dos atributos do objeto ou ação, ele dirige a percepção objetal e a cadeia de ações.

$\leftrightarrow$ A configuração do contexto de jogo deve garantir, desde o planejamento, a interação em diversas direções, através da qual se estabelecem zonas de desenvolvimento proximal. O tipo de proposta, as condições em que é postulada e o comportamento habitual dos alunos são fatores complementares na definição do tipo de configuração: em duplas, quartetos, grupo de toda a classe e outras variações.

$\stackrel{\leftrightarrow}{\rightarrow}$ As características funcionais e estruturais do jogo favorecem a emergência e 0 desenvolvimento dos processos psicológicos superiores. A colaboração entre educador e educando, estabelecida por meio de zonas de desenvolvimento surgidas em meio a uma dada situação lúdica, põe em funcionamento o potencial de mudança nas relações entre o campo perceptivo e simbólico, altera e controla consciente e voluntariamente sua conduta, expande os limites de sua imaginação, aspectos basilares das formas mais abstratas e generalizadas de representar 0 mundo.

$\stackrel{4}{4} \mathrm{Na}$ dupla natureza do jogo, regras e imaginário sustentam o movimento alternado entre proximidade e distanciamento da realidade, subordinação e libertação, imitação e criação original. Nesse processo, os signos lingüísticos desempenham uma função de grande relevo. Ao longo do desenvolvimento do jogo, passam a ocupar o lugar de objetos/ações substitutivos ou pivôs, num sistema ordenado (mediações externas convertidas em internas), imprescindível à representação generalizada, em que elementos da realidade são combinados e transportados a outra dimensão, numa realidade virtual, reinventada.

Esses princípios nos levam a creditar ao jogo um papel potencializador da aprendizagem escolar na medida em que, transformado em educativo, seus objetivos lúdicos sejam coordenados aos de ensino. Mediante eles, elaboramos nossa proposta ludo-educativa de formação de professores, sistematizada pela proposição de alguns critérios. Nos sete primeiros, destacaremos o papel mediador do educador; nos quatro seguintes, as interações entre alunos.

1 - Atribuição de significados ao aprendido: ao montar as peças de um jogo no tabuleiro, a criança sabe por que o faz. Muitas vezes, na escola, vê-se diante de tarefas que não the fazem sentido. Se perguntada por que as realiza, é capaz de dizer "para tirar nota" ou "porque a professora mandou". Por isso, é imprescindível pensar sobre a relação de cada atividade com os objetivos de ensino, bem como com as demais, anteriores e posteriores, formando uma cadeia que as integre. De nada adiantaria confeccionar fantoches se não fossem vinculados à possibilidade de inventar um personagem, uma história, representar, escrever sobre o fantoche ou sobre a representação, etc. 
2 - Participação dos alunos: através dela, o educador retira informações para sua intervenção. Nesse ponto, é particularmente notório o papel desempenhado pelos conceitos cotidianos no jogo, com a concretude e a funcionalidade que lhes são peculiares. Integrá-los ao ensino permite ajustar o nível de dificuldade da atividade, modelar explicações e instruções, além de enriquecer o conhecimento de caráter abstrato a que os alunos estão sendo expostos. Evidentemente, outros aspectos estão envolvidos para que não se torne uma 'coleta' de experiências cotidianas, o que criaria um falso artifício, completamente inócuo. Variar propostas, desde jogos coletivos em pequenos grupos até os de atuação individual; distribuir atividades diferentes e complementares entre os componentes de um grupo de jogo; criar situações de opção para os alunos; diversificar materiais; solicitar produtos com qualidades distintas durante e após a realização da atividade (protótipo, tabelas ou quadros, redações, apresentação oral) são exemplos de inúmeras alternativas das quais o educador lança mão para proporcionar a todos oportunidade de participar ativamente do que acontece em aula.

3 - Despertar a curiosidade pelo conhecimento: muito acertadamente se compara 0 ato de conhecer a situações de forte envolvimento, passionais. A curiosidade pelo saber depende da auto-estima e do autoconceito dos alunos, melhor desenvolvidos num clima favorável à afetividade. É preciso acreditar que a cada nova jogada há de se adquirir maior habilidade para transpassar os obstáculos, que a competência atual pode ser aprimorada, que se pode investir em si mesmo para a continuidade do jogo, desejando chegar ao final. Assim, esse terceiro critério refere-se à criação de um clima lúdico de ensino, de modo que a carga afetiva implicada na atividade lúdica contribua para a curiosidade pelo conhecimento. 0 reconhecimento (autoconceito) e a valorização (auto-estima) das próprias capacidades se emolduram num cenário em que o jogo instaure confiança, segurança e aceitação mútuas, criando e mantendo a curiosidade e o interesse pelo conhecimento. Desse modo, o conhecimento se torna singularmente objeto de curiosidade. A criança testa, sem medo, todo o seu potencial. Nisso reside a flexibilidade e a frivolidade, apontadas por Brougère (1997) como expressões do jogo:

Essa situação, frívola diante da parada de obrigações e condições de vida cotidiana, [é] um espaço único de experiências para aquele que brinca. Ele pode tentar, sem medo, a confirmação do real... ; pode, sem riscos, inventar, criar... A brincadeira é 'um meio de minimizar as conseqüências de seus próprios atos'e, por isso, aprende numa situação que comporta menos riscos. (p.102-103)

\section{4 - Organização do cenário de aprendizagem em pequenos grupos ou duplas:} não serve apenas para propiciar interação entre pares (assunto que abordaremos mais 
adiante), mas é igualmente salutar ao educador. O jogo em pequenos grupos libera, instrumentaliza o educador. Ele pode examinar mais detalhadamente o processo de aprendizagem de cada aluno, e deste com seus pares, enquanto a gestão da aula está sendo controlada pelo jogo, com os alunos posicionados de modo participativo, envolvido e com razoável autonomia. Dessa observação podem ser extraídos indicadores preciosos para ajustes no planejamento ulterior, comparando expectativas com a situação concreta.

5 - Atitude metacognitiva dos alunos: são particularmente interessantes as situações em que os alunos são postos como especialistas, explicando seu raciocínio, hipóteses e idéias. Sobretudo nos jogos coletivos, conscientizar-se do princípio de subordinação a regras implica em profundas mudanças do ponto de vista psicológico. As regras postulam certa eqüidade entre os participantes, tornando viável comparar o próprio comportamento ao dos demais e se auto-avaliar em termos de destreza, habilidades e progressos.

É a partir dessa comparação que se origina a avaliação consciente e independente que a criança faz de suas habilidades e possibilidades concretas. Esta não é a avaliação que ela obtém daqueles que a cercam; [nos jogos coletivos] pela primeira vez, ela começa a julgar, por si mesma, suas próprias ações. (Leontiev, 1988: 139)

A ajuda do educador deve ser a menor possível, intervindo sobretudo no sentido de encorajar os alunos a se posicionarem autonomamente diante da tarefa.

6 - Conceitos advindos de experiências não escolares: de origens distintas, os conceitos cotidianos e científicos podem e devem ser inter-relacionados no contexto escolar. Ao explicitar constantemente as relações entre ambos, bem como organizar a seqüência curricular segundo essas relações, o professor fomenta um conjunto de elaborações sucessivas, num crescente grau de complexidade, generalização e descontextualização.

\section{7 - Funcionalidade da comunicação:}

A fala ocupa um lugar central na criação e intervenção nas ZDP, porque é o instrumento fundamental por meio do qual os participantes podem comparar e modificar seus esquemas de conhecimento e suas representações sobre aquilo que está sendo ensinado e aprendido. (Onrubia, 1999: 142)

A comunicação clara, precisa, acessível implica lidar com a polissemia das palavras, negociando sentidos em busca de significações, nas quais se fundamentam os conceitos. Não basta jogar, é preciso falar sobre o jogo, numa atitude auto-avaliativa. Enquanto expressa o que sabe, 0 aluno pensa sobre o que sabe e pensa em como comunicar o que sabe, aspectos que legitimamente são essenciais ao alargamento da ZDP.

Desse modo, Onrubia frisa que

a importância de assegurar as relações entre as novas representações 
promovidas por meio da linguagem e as já existentes, e a necessidade de que não se produzam rupturas nem distâncias excessivas entre a linguagem do professor e a compreensão dos alunos lao mesmo tempo em que a linguagem é um] instrumento para a modificação e reconstrução, em um nível superior, dos significados que eles possuem. (id., p.144)

Nos sete critérios anteriores, dirigimos essencialmente nosso discurso ao papel do professor, afirmando que se trata de uma intervenção sempre construtivamente partilhada com os alunos, negociando e mobilizando-os a participar. Dedicar-nos-emos agora à atuação dos alunos.

1 - Interação aluno/ aluno: para Vygotsky, "o caminho do objeto até a criança e desta até o objeto passa através de outra pessoa" (1994: 33). O desenvolvimento se dá no plano interpsicológico inexoravelmente antes de se tornar intrapsicológico. Todo percurso de internalização pressupõe parceria. Em contraponto ao papel do professor, a parceria entre alunos thes possibilita ir além do que iriam sozinhos, estabelecendo e ampliando a ZDP em que atuam. Como companheiros no jogo, eles se complementam, divergem, adicionam, negam, questionam e interferem mutuamente nos modos em que realizam a atividade.

A parceria dos alunos caracteriza-se pela proximidade da linguagem e pelas relações de poder, devido o fato de se excluir da relação a imagem fixada de mestre-aprendiz. Há maior potencial de flexibilidade para se trocar de papel. As hipóteses de um podem ser confrontadas com as de outro. É necessário aprimorar o discurso explicativo, citar exemplos, colocar à prova, avaliar resultados. A ZDP não se instaura somente para o menos experiente. Aquele que, sob determinada informação ou procedimento, 'sabe mais' que o outro, é igualmente beneficiado ao ter de explicitar seu processo de raciocínio até ser compreendido.

2 - Auto-regulação do comportamento: do ponto de vista intelectual, auto-regular o comportamento, detectar incongruências e lacunas, dirigir conscientemente a fala para ser mais preciso e explícito, encontrar intencionalmente alternativas na formulação de uma mesma idéia e agregar exemplos coerentemente são algumas das ações mentais necessárias para se comunicar com os companheiros.

Exemplarmente, citemos o caso em que a criança esteja aprendendo a pensar sobre as regras de um jogo. Mesmo familiar e pertencente ao seu repertório, explicá-lo é completamente diferente de jogá-lo. Ela reconhece a seqüência e a coerência entre as regras, mas, ao ter de explicar como se joga, deixa transparecer todo o árduo processo de construção da consciência sobre as regras. Primeiro, focaliza ações isoladas como imagens completas - sem perceber que são insuficientes para toda a explicação - de forma desordenada, com acréscimo de comportamentos inespecíficos ou menos pertinentes para particularizar o jogo. Nesse momento, a intervenção correta em direção à construção de 
imagens melhor definidas sobre os objetivos e as estratégias do jogo vão paulatinamente auxiliando na organização de um esquema que estabelece redes interconceituais sobre os elementos principais do jogo, sua seqüência lógica e definição das regras básicas, reconstruindo-o mentalmente para ter condições de explicá-lo de modo efetivo. Tal reordenação mental tenderá a propiciar, por conseguinte, melhor performance futura, na medida em que a tomada de consciência sobre como atuar permite corrigir ou aperfeiçoar com maior detalhamento os comportamentos cabíveis ao objetivo primordial.

3 - Desenvolvimento cognitivo: A importância do jogo no desenvolvimento da abstração e da volição consciente reside no fato de que a atividade lúdica se movimenta dentro de um campo abstrato, através do qual os significados passam a predominar sobre as ações, ou seja, a ação lúdica se subordina aos significados - objetivo e regras - do brincar (significado/ação).

A fim de manter a situação lúdica, a criança aceita as condições impostas pelo jogo, modificando sua percepção e seu comportamento. Dessa forma, as ações e os objetos lúdicos são orientados para o objetivo lúdico, promovendo a superação do pensamento egocêntrico.

Não é tarefa fácil ter que explicar o próprio ponto de vista, reconhecer o alheio e encontrar uma saída mutuamente satisfatória. Propulsora da descentração, ou seja, superação do egocentrismo cognitivo, esta capacidade refere-se à relatividade do próprio pensamento, que se reflete em atitudes de aceitação e respeito mútuos.

4 - Afetividade: a interação entre alunos requer alguns cuidados. Não é suficiente terem algum grau de conhecimento sobre o tema da atividade. A situação mobiliza afetos e exacerba conflitos. Em decorrência do conhecimento acerca do que os alunos sabem e de como atuam, deve-se adequadamente planejar, escolher os materiais, instruir e organizar a atividade para que o exercício da cooperação, do respeito, da autonomia efetivamente se concretize.

Por trás das letras é uma coleção de vídeos ${ }^{21}$ que privilegia a interação entre pares. Trabalhando em duplas, os garotos se vêem diante de tarefas, como escrever uma parlenda. Um escreve, outro corrige a escrita. Quem escreve concentra-se na tarefa de transpor ao papel o que o outro diz, sem se preocupar com a significação das palavras. Seu colega assume o papel de se lembrar da parlenda e de cada palavra que a forma, ou seja, controla a escrita do colega ("não, não, você já escreveu isso aí, agora é 'ali'” - indicando a escrita do advérbio, tendo que negociar o sentido do que é preciso fazer, pois quem escreve passa a

\footnotetext{
${ }^{21}$ Weisz, T. (1994). Por trás das letras. São Paulo: FDE.
} 
procurar uma palavra escrita em outro lugar). A negociação promove a auto-regulação: aos poucos, descobrem que um precisa falar mais pausadamente; outro precisa marcar o tempo, falando em voz alta cada sílaba da palavra que escreve.

Por ser imbuído de regras, implícitas ou explícitas, o jogo normatiza a conduta, facilitando a descentração. Basta compararmos o que ocorre numa situação escolar lúdica com uma não-lúdica. No primeiro caso, mais seguramente, cada qual tenderá a aguardar a vez, respeitar o outro, compartilhar conhecimento, etc, posto que assumem as regras do jogo como regras de conduta.

Evidentemente, alguns jogos - dependendo dos objetivos a serem alcançados - podem ser mais apropriados que outros. Não há como negar que o tipo de jogo influi tanto quanto a maneira que é proposto e instaurado. Em resumo, escolher adequadamente o momento, o tipo e especialmente a maneira como um jogo entra na sala de aula faz toda a diferença entre a produção de um conflito exacerbado, improdutivo, e um clima lúdico e afetivamente favorável à aprendizagem. Trata-se, então, de dirigir a atenção a aspectos metodológicos que confluam para uma prática docente lúdica capaz de atingir os objetivos escolares. 


\section{3 - ENFOQUE TEÓRI CO DA ANÁLISE DO PROJ ETO FORMATI VO}

O epicentro de nosso estudo constitui-se do cruzamento entre duas linhas de investigação. De um lado, encontra-se o desenvolvimento profissional do educador; de outro, a prática ludo-educativa de ensino.

O aprofundamento das revisões bibliográficas nos impôs o seguinte questionamento: de que maneira poderíamos alcançar a análise da formação de professores sem abandonar os princípios da abordagem da ludo-educação?

Enfatizamos, na investigação empírica, a formação continuada de professores e assumimos o papel de formadores, fundamentando-nos na abordagem teórica de matiz histórico-cultural.

Através de conceitos de origem vygotskiana e das pesquisas de Elkonin, principalmente, formulamos nossa compreensão de jogo educativo ${ }^{22}$. 0 percurso formativo baseou-se nas noções de mediação semiótica, interação social e processo de internalização. Conferimos ao jogo a característica de criador de zonas de desenvolvimento proximal, pelas quais educador e educando experienciam situações-problema que façam emergir e desenvolver processos psicológicos essenciais da aprendizagem, destacando-se os de generalização, descontextualização e metacognição.

As conceituações histórico-culturais, tanto na obra de Vygotsky quanto na de seguidores da vertente teórica consultada, retratam jogo e processos de formação de conhecimento com enfoque acentuado no desenvolvimento infantil. Desse modo, tal conceituação não pode ser transferida ipsis litteris para os objetivos formativos de nosso trabalho, já que as necessidades formativas do adulto não são igualadas às da criança.

Da mesma maneira, revelou-se inatingível analisarmos, na profundidade desejada, 0 processo de transformações dos saberes da prática pedagógica a partir do conhecimento histórico-cultural produzido.

O aporte histórico-cultural foi pano de fundo de nossas ações e estratégias formativas. Com ele, alinhavamos o entendimento de formação de professores como reflexiva, por meio da qual o processo de desenvolvimento profissional toma corpo por um saber-fazer definido por apropriações autônomas e reflexivas que o docente constrói sobre o que vem a ser jogo educativo e como se inspirar nele para transformar sua atuação pedagógica, estabelecendo mudanças significativas na própria concepção da docência.

O impasse na eleição de um postulado que se afinasse com toda a pesquisa empírica já

22 Conforme tratado no capítulo anterior, jogo educativo é provido da capacidade de criar campos de experimentação de habilidades, modos de operar mentalmente e agir no mundo que desafiam o conhecimento já internalizado, gerando zonas de desenvolvimento proximal. 
consolidada e com as diretrizes do estudo somente foi suplantado quando conhecemos a teoria da Aprendizagem Experiencial, formulada por David Kolb ${ }^{23}$ (1984), cujo acento recai sobre o desenvolvimento do adulto e tem forte inspiração na acepção histórico-cultural.

Para Kolb, é verdadeiro o princípio histórico-cultural de que a raiz do desenvolvimento encontra-se nos processos de aprendizagem. Com vistas a contribuir para o desenvolvimento profissional e abarcar a aprendizagem experiencial do adulto, 0 autor se orienta por princípios e conceitos originalmente construídos por Vygotsky, mormente os de zona de desenvolvimento proximal, mediação, internalização e processos de desenvolvimento e de aprendizagem.

O foco de interesse e os apontamentos de Kolb sobre a conceituação histórico-cultural não objetivam seguir com exclusividade o aporte vygotskiano. Suas formulações e estudos apontam outras acepções, principalmente as de Dewey, Piaget e Lewin. Entretanto, o cuidado e a complexidade com que a Aprendizagem Experiencial é proposta não se referem a uma somatória de preceitos de diferentes raízes epistemológicas, mas sim a um amálgama refinado no qual se encontram sínteses articuladas de diferentes origens teóricas.

Nosso projeto de formação assemelha-se à teoria kolbiana por se reportar à experiência de ensino lúdico e ao processo de aprendizagem de adultos - no caso, professores.

Através da conceituação de Aprendizagem Experiencial, tornou-se factível analisar 0 projeto de formação ludo-educativa de professores.

O encontro de outras vozes que trilharam caminhos semelhantes legitima a viabilidade do olhar histórico-cultural no projeto formativo de professores.

\section{1 - Aprendizagem Experiencial - Conceituação}

A Aprendizagem Experiencial é uma teoria de desenvolvimento do adulto. 0 pilar primordial é que todo desenvolvimento prospectivo decorre da aprendizagem atual, bem como todo aprendizado prescinde de processos psicológicos em desenvolvimento.

Aprendizagem experiencial não significa vivência qualquer. Ela é demarcada pela ação sobretudo mental - isto é, a apropriação de saberes procedentes da experiência demanda processos contínuos de ação e reflexão.

A experiência é permeada por conhecimentos que, aprendidos, engendram

\footnotetext{
${ }^{23}$ A obra de Kolb nos foi apresentada pela co-orientadora deste estudo, Profa. Dra. Júlia Oliveira-Formosinho, durante estágio realizado na Associação Criança, Braga (Portugal). David A. Kolb é professor de Comportamento Organizacional em Weatheread, EUA. Bacharelou-se pela Faculdade de Artes de Knox, em 1961, e recebeu 0 título de PhD por Harvard, em 1967. Além de ser o mentor da teoria de Aprendizagem Experiencial, Kolb é reconhecido também pela contribuição em torno da pesquisa sobre comportamento organizacional. Sua obra se assenta no interesse pela natureza da transformação individual e social e pela relação entre aprendizagem e desenvolvimento profissional.
} 
desenvolvimento. As relações não são lineares nem unilaterais, mas sim um todo entrelaçado e multifacetado. O desenvolvimento reporta-se a um leque de conteúdos ou conhecimentos em pauta, por isso se vincula à aprendizagem. Aprender é sempre relativo a algo, originário da experimentação do/com o mundo, isto é, a experiência está no âmago da transformação do conhecimento. Mediante os saberes aprendidos, o desenvolvimento pode ser propiciado, formulando-se sistemas ordenados de conceitos que retornam à experiência.

A Aprendizagem Experiencial constitui-se como teoria educacional, considerando o homem um ser integrado ao meio natural e cultural, capaz de aprender a partir de sua experiência e da reflexão consciente sobre a mesma. Uma pessoa aprende motivada por seus próprios propósitos, ou seja, empenha-se deliberadamente na obtenção de aprendizado que lhe faça sentido.

Kolb define aprendizagem experiencial como:

o processo por onde o conhecimento é criado através da transformação da experiência. Esta definição enfatiza... que o conhecimento é um processo de transformação, sendo continuamente criado e recriado... A aprendizagem transforma a experiência tanto no seu caráter objetivo como no subjetivo... Para compreendermos aprendizagem, é necessário compreendermos a natureza do desenvolvimento, e vice-versa. (1984: 38)

A aprendizagem pela experiência não se molda unilateralmente pela razão e pela reflexão. A formação experiencial atribui um papel igualmente decisivo no que se refere à vida, incluindo emoções, sentimentos e intuições, ou seja, ao que genericamente constitui as experiências de vida (Alarcão, 2002).

Assim, o funcionamento psicológico para o aprendizado é entendido como uma estrutura holística e auto-regulada, em que cognição, afetos, percepção e ação estão em contínua transformação consciente.

As origens intelectuais da aprendizagem experiencial de David Kolb advêm das obras de John Dewey, Kurt Lewin e Jean Piaget, cujas proposições teóricas ele considera basilares do aprendizado experiencial. Em sua obra de maior projeção, Experiential Learning (1984), o autor também freqüentemente se reporta a Lev Vygotsky ${ }^{24}$.

Segundo Kolb, a Aprendizagem Experiencial referencia-se nessas teorias para ser um

24 Deliberar sobre críticas à teoria de Kolb não é nosso interesse, nem interfere nos objetivos deste estudo. Entretanto, um dos aspectos que mais distancia seu posicionamento teórico do histórico-cultural (que modelou o projeto formativo) reside no fato de que se detenha mais na experiência preliminar e direta, em detrimento da noção de aprendizagem indireta, relativa à obtenção de conhecimentos que não sejam vivamente experimentados pelos sujeitos, por comunicação de experiências entre as pessoas (Jarvis, 1995). Essa crítica se apóia nos estudos experimentais de Kolb, marcadamente de experiência direta. Porém, é válido salientarmos que em sua obra Experiential Leaning não encontramos negação explícita da relevância da aprendizagem indireta, sugerindo que não haja axioma impeditivo para que pesquisas abordem aspectos lacunares da teoria. 
campo de estudo destinado a balizar a análise dos fatores que interligam desenvolvimento pessoal, educação e trabalho.

De Kurt Lewin - autor da célebre frase: "nada é tão prático como uma boa teoria"- Kolb destaca o legado de sua obra sobre dinâmicas de grupo e suas contribuições no desenvolvimento da metodologia de pesquisa-ação. A proximidade entre os autores revelase por defenderem a mesma idéia, a de que teoria e prática se retroalimentam. Da mesma maneira que "o tema consistente em toda a obra de Lewin é sua preocupação pela integração entre teoria e prática" (id., p.9), o propositor da Aprendizagem Experiencial anuncia que a razão da teorização está na sua capacidade de iluminar a prática, e viceversa.

De Piaget, a Aprendizagem Experiencial empresta uma condição básica para sustentar o desenvolvimento cognitivo: a experiência permeia todo o processo dialético firmado entre conhecimento e aprendizado. Os conceitos piagetianos de assimilação e acomodação são recorrentes na obra de Kolb e se destinam a explicar diferentes momentos da aprendizagem pela experiência. 0 autor se reporta, por exemplo, a conhecimento assimilado como fruto de reflexões e observações a partir da vivência de aprendizagem.

Dewey concebe a experiência como um foco organizador da aprendizagem. Para ele, não seriam os esquemas conceituais arrojados e distantes da experiência real que alicerçariam a educação, sugerindo que:

Se tenta-se formular a filosofia da educação implícita nas práticas da
nova educação, eu acho que podemos descobrir alguns princípios
comuns...A imposição vinda de cima opõem-se expressão e cultivo à
individualidade; à disciplina externa, opõem-se atividade livre; ao
aprendizado advindo de textos e professores, aprendizado através da
experiência; à aquisição de práticas e técnicas isoladas pelo exercício,
opõem-se a aquisição delas como meio para se atingir objetivos que têm
apelo direto e vital; à preparação para um futuro mais ou menos remoto,
opõem-se o fazer o máximo das oportunidades da vida presente; às
metas estáticas e materiais, opõem-se aquisição em um mundo
mutante... Eu considero que a unidade fundamental da nova filosofia é
encontrada na idéia de que há uma relação íntima e necessária entre os
processos de experiência real e educação. (Dewey, 1933 apud Kolb,
1984, p.5)

"Aprendizagem é o processo por onde o desenvolvimento ocorre" (id., p.132). Esse ponto de vista, kolbiano, difere de algumas concepções tradicionais que aludem à relativa independência entre os dois processos.

Dentre os exemplos citados pelo autor, a postura clássica piagetiana é questionada por sugerir que aprendizagem é um processo subordinado, e não ativamente envolvido com desenvolvimento. Nessa perspectiva, aprender é fazer uso de desenvolvimento efetivo, sem 
que a aprendizagem modifique o curso de desenvolvimento. Em resumo, Kolb considera que, para o criador da epistemologia genética, o desenvolvimento forma uma superestrutura na qual a aprendizagem ocorre.

Por outro lado, na teorização de Kolb - da mesma maneira que na abordagem históricocultural - a aprendizagem resulta da ação do homem sobre o ambiente, erigindo reações em que ambos saem modificados. À medida que o homem tem capacidade de atribuir significado à experiência vivenciada, revendo-a e planejando seu futuro, tanto o ambiente como ele próprio se transformam, ambos simbólica e concretamente metamorfoseados pela mão humana.

Esse aprendizado releva dois processos que, equilibrados, são forças elementares mas imperativas do processo educativo:

a) a aprendizagem é individual na medida em que toda atividade educativa é uma libertação de forças, tendências e impulsos existentes no indivíduo, elementos volitivos de direção e de orientação da atividade.

b) vida social e educação se prolongam reciprocamente, pois comunicação e transmissão são fundamentais na inter-relação dos grupos humanos. Toda educação é social, é uma conquista de um modo de agir comum. Nada se ensina, nem se aprende, senão através de uma compreensão comum ou de um uso comum. O conhecimento é social, "não existe somente em livros, fórmulas matemáticas ou sistemas filosóficos; requer aprendizagem interativa para interpretar e elaborar estes símbolos" (id., p. 122).

A Aprendizagem Experiencial enfatiza a relação de interdependência entre características internas do ser aprendente e circunstâncias externas do ambiente de aprendizagem, entre conhecimento de origem pessoal e social. Isso equivale dizer que aborda a relação homem e meio social dialeticamente, em mútua transformação.

Reiterando que a aprendizagem é um processo eminentemente social, advinda sobremaneira da experiência com e na realidade social, o autor afirma que

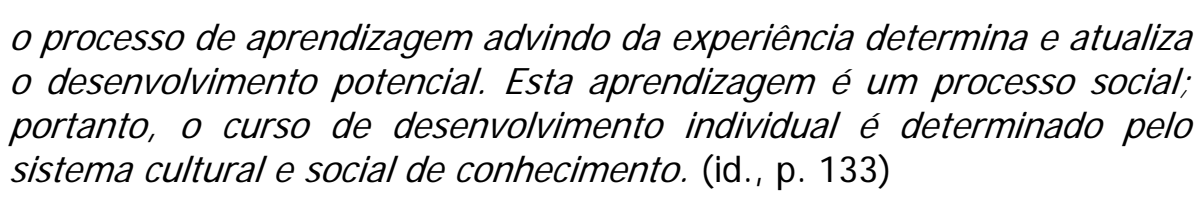

Kolb sustenta essa posição teórica no conceito de zona de desenvolvimento proximal de Vygotsky, interpretando-a como um princípio metafórico, impossível de ser identificada na ação real porque representa a multiplicidade de dispositivos culturais, dirigidos à promoção de desenvolvimento. Não se trata de um lugar específico, mas sim de um regime de práticas que engendram a apropriação, pelos sujeitos, de um sistema particular de regras, simultaneamente 'apoderadas' pela cultura através da mediação dos mesmos dispositivos. 
Através de experiências de imitação e de comunicação com outras pessoas e de interação com o ambiente físico, as potencialidades de desenvolvimento são estimuladas e postas em prática até que internalizadas como desenvolvimento efetivo (real) independente. (ibid.)

O aprendizado é um veículo de desenvolvimento pela interação social. Nada tem de metafísico, pois retorna ao seio cultural através da criação humana de símbolos, ferramentas e outros artefatos artificiais.

O elemento comum aos autores - além da centralidade dada à experiência na educação - é a defesa, através do processo dialético, de aprendizagem e desenvolvimento do pensamento, tomando como pressuposto que a aprendizagem é um processo ininterrupto ao longo da vida do indivíduo e que o desenvolvimento se define pela experiência, mediante o direcionamento a um propósito específico (meta de aprendizagem).

Aprendizagem Experiencial é definida, portanto, por princípios educacionais construídos mediante uma visão clara do ser humano que se quer formar e do papel da educação nesse processo. Conforme enfatiza Kolb, as referências daqueles autores se reúnem em sua teorização por terem em comum a busca de uma compreensão do desenvolvimento que não se curva ao empirismo nem ao idealismo epistemológico, da mesma maneira que a teoria do aprendizado experiencial se diferencia...

de teorias racionalistas e outras teorias cognitivistas que tendem a dar ênfase primordial à aquisição, manipulação e uso de símbolos abstratos, e de teorias comportamentais de aprendizado que negam qualquer papel à consciência e à experiência subjetiva no processo de aprendizado. Deve-se enfatizar, no entanto, que o objetivo deste trabalho não é colocar a aprendizagem experiencial como uma terceira alternativa (...), mas sim sugerir, através da aprendizagem experiencial, uma perspectiva holística, integrativa, que combina experiência, percepção, cognição e comportamento. (id., p.20-21)

Todas as considerações apontadas constituem base do aprofundamento sobre a teoria da Aprendizagem Experiencial. Na seqüência deste capítulo, abordaremos princípios, conceitos e processos cruciais da efetiva prática da aprendizagem de adultos, tornando-a instrumental para aproximarmos o escopo de nosso projeto de formação continuada de professores da análise sobre sua qualificação para promover desenvolvimento profissional. Trataremos das características essenciais da teoria kolbiana, da qualificação de suas quatro modalidades de aprendizagem, dos conceitos de integração e diferenciação que determinam o processo de desenvolvimento profissional. 


\section{2 - Aprendizagem Experimental - Características}

\subsection{1 - Aprendizagem está nos processos, e não nos produtos}

As idéias não são elementos fixos e imutáveis de pensamento, estão sempre se formando e reformulando por meio da experiência ou, mais precisamente, das significações dadas a ela.

O confronto de idéias é inexorável na aprendizagem porque, do movimento que causa, torna possível arquitetar conhecimentos de maior sofisticação. Aprofundamento, generalização e complexidade de idéias são possibilidades surgidas da elaboração de outras, novas, ainda não acabadas, mas que sinalizam transformação daquilo que se sabe, do conhecimento pré-existente.

Conhecer é um processo, e não um produto; emerge da contínua invenção e recriação hipotética sobre a realidade. Destarte, a palavra-chave para se compreender aprendizagem como processo é 'formulação de hipóteses'.

Hipotetizar é tornar explícitos elementos inteligíveis de nossa experiência. É pensar sobre, recorrendo a idéias e conceitos conhecidos e formulando outros. Formular hipóteses é engendrar modos de agir que nos fazem capazes de articular o que conhecemos em função dos propósitos de uma situação experiencial em particular.

Diante de uma experiência que nos envolve, unimos e selecionamos informações, aprimoramos procedimentos, separamos e elegemos elementos que a compõem, ordenamos esses elementos em seqüências distintas, adicionamos novos. Portanto, são diversas as operações de pensamento antes mesmo de testarmos as hipóteses que, inicialmente amórficas e nebulosas, são revistas, reelaboradas e aprimoradas, tornando-se sólidas o suficiente para serem postas em prática em novas experiências.

A generalização é um aspecto de capital importância na criação de hipóteses. Generalizar envolve uma escala de ações realizadas numa circunstância particular que gera aprendizagens para além de um exemplar particular experienciado, sugerindo amplitude de princípios teóricos. Hipotetizar princípios não implica somente habilidade de expressá-los por meio simbólico, isto é, de expor com palavras. Antes, implica habilidade de observar conexões entre ações e seus efeitos, numa escala de circunstâncias.

Hipóteses generalizáveis são conjecturas que visam antever situações análogas à vivenciada e conceber previamente como atuar nelas.

\subsection{2 - Desenvolvimento unilinear e multilinear}

Contrária ao posicionamento historicamente marcado pelo acento na dimensão cognitiva, 
a teorização de Kolb compreende que o processo educativo transcende 0 aspecto como multifacetado. A aprendizagem experiencial rejeita a perspectiva unilinear de desenvolvimento, porque a cognição (ou a recognição) não progride separadamente das outras dimensões de desenvolvimento, visto que a inteligência humana nasce do conflito e do diálogo entre cognição, afetividade, percepção e ação.

Kolb concebe desenvolvimento como produto da interação entre conhecimento pessoal e social, definindo-a como 'perspectiva transacional' do desenvolvimento. Nesse aspecto, a teoria da aprendizagem experiencial se difere da inspiração piagetiana por enfatizar que no adulto o desenvolvimento é um processo multilinear. Kolb se apropria da noção de universalidade piagetiana para convertê-la em universalidade relativa, pois a cultura na qual um grupo está inserido é, para o mesmo, um campo universal de conhecimentos socialmente produzidos, formando a base para que os seus membros compartilhem de posições, julgamentos, crenças, mitos e ideologias tão universais quanto os domínios de conhecimento existentes. Sob este ponto de vista, é interessante notar que este universal relativo segue os parâmetros ditados por aquele campo social específico.

A ênfase na cognição converte o desenvolvimento do adulto num curso linear de progressão dos processos de apropriação, articulação e transformação do conhecimento e da atuação na realidade. Nessa vertente, a cognição é uma superestrutura que governa o comportamento.

Kolb avalia que esta visão está presente nas abordagens do desenvolvimento cognitivo, de Piaget (Flavell, 1963); do desenvolvimento egóico, de Loevinger (1976); do desenvolvimento moral, de Kohlberg (1969) e para o sistema conceitual de Harvey, Hunt e Schroeder (1961), além das derivações que cada um desses autores faz a partir desse sistema.

Se, por um lado, Kolb se distancia dessas vertentes, por outro pondera que elas trazem parâmetros importantes para postular sua própria compreensão sobre aprendizagem. Conforme mencionamos anteriormente, tal atitude se deve mais por rigor científico do que por fragilidade conceitual.

Na mesma linha de raciocínio, não é mera coincidência que a caracterização do autor sobre desenvolvimento exprima idéias familiares ao arcabouço histórico-cultural. Kolb se inspira sobretudo no que Vygotsky já havia descrito sobre os processos de formação de conceitos, nos quais a generalização e a descontextualização ${ }^{25}$ são processos inerentes,

25 Embora sejam definições originadas no referencial de Vygotsky, a alusão às idéias de descontextualização e generalização, vitais ao processo formativo, auxiliam a construir relações com dois conceitos kolbianos que serão abordados neste capítulo: integração hierárquica e diferenciação crescente. 
interdependentes, complementares.

Exemplarmente, a conceituação kolbiana reporta-se à noção piagetiana de adaptação e a modifica, tornando-a referência para enfatizar a idéia de que o aprender e o desenvolver são processos transacionais, determinados pela relação entre o indivíduo e o meio cultural do qual faz parte.

Desse modo, Kolb interpreta adaptação como "adaptação pró-ativa", determinada por um movimento dialético contínuo. Esse conceito guarda um sentido pragmático por se referir tanto à transformação do meio como também às alterações do homem em função das forças opostas ocasionadas por sua ação no mundo:

A aprendizagem experiencial coloca a ênfase na interação entre o sujeito e a ação e sustenta as novas aprendizagens na experiência, ao mesmo tempo em que valoriza o contexto e a reflexão. Mas, ao valorizar também o lado funcional da aprendizagem, sua exteriorização social, adquire uma dimensão pragmática que, como vimos, é essencial (não apenas) porque promove a resolução de problemas pelos atores envolvidos, mas também por conceder a estes o poder de os resolver e a consciência de que detêm esse poder. (Alarcão, 2002: 230)

Nos termos em que é proposta, a "adaptação pró-ativa" é vigorosamente históricodialética, característica distintiva do aprendizado humano, respaldando-se nos instrumentos culturais auxiliares (mediadores) e no conhecimento historicamente produzido e circulante na sociedade. É uma aprendizagem mergulhada na produção cultural, que ativamente transforma a qualidade dos conhecimentos que cada pessoa possui. As mudanças ocorridas em termos de conhecimentos projetam alterações no âmbito do desenvolvimento.

É pela espiral entre ação e reflexão (subsidiárias do aprendizado) que o homem transforma a si e o seu entorno social. Para promover desenvolvimento, o processo de aprendizagem requer confrontação e resolução dos conflitos dialéticos inerentes à aprendizagem experiencial. “Este processo dialético de aprendizagem estabelece 0 progressivo desenvolvimento humano, pela crescente diferenciação e pela hierarquização integrativa do funcionamento psíquico" (Kolb, 1984: 134, grifos nossos).

\subsection{3 - Aprendizagem é um processo contínuo e ascendente impulsionado pela experiência}

$\mathrm{Na}$ aprendizagem experiencial, o processo de desenvolvimento é representado por três níveis sucessivos que equivalem a três esferas qualitativamente distintas de consciência, conforme a complexidade das ações e dos processos reflexivos de cada ser singular.

Em seqüência, os três níveis de diferenciação do desenvolvimento são: aquisitivo, especializado e integrativo. 
O progresso de um para o outro varia em íntima dependência com as experiências culturais que cada pessoa em particular vivencia, determinando oscilações entre um nível e outro. Por isso, não se pode estipular ou classificar o modo de aprender de um indivíduo. Por exemplo: um piloto de avião que não dirige automóvel terá um nível integrado de consciência quanto à aprendizagem relativa para pilotar aeronaves em contraponto com o nível aquisitivo relativo para dirigir um fusca. Contudo, somente ao dar início ao aprendizado automobilístico, tornar-se-á explícita e factível a maneira como o nível integrativo para pilotar o auxilia no novo empreendimento.

Antes de tratarmos mais profundamente o entrelaçamento dos diferentes níveis de desenvolvimento e consciência, precisamos explicitar de maneira isolada como Kolb os conceitua.

\section{a) Nível aquisitivo de desenvolvimento - consciência identificadora}

Nesta primeira etapa, ao nos depararmos com um conhecimento novo, o desenvolvimento é performático. Por isso, Kolb postula que seja governado por uma consciência 'identificadora' (registrative consciousness).

O nível de aquisição é marcado pela aprendizagem de habilidades básicas e pela constituição de estruturas cognitivas, cujo ápice de desenvolvimento manifesta-se pela capacidade de simbolizar, de representar a realidade de uma forma totalmente independente da realidade concreta, ou seja, da total consciência entre realidade virtual - idealizada e fantasiosa - e realidade concreta. São produtos desse desenvolvimento a lógica representacional e o processo racional de construção de hipóteses e deduções.

Estas capacidades permitem imaginar ou hipotetizar implicações dentro de um sistema puramente simbólico e de testá-los na realidade, convergindo em aprendizagem pela transformação de uma dada compreensão por extensão a outros setores de conhecimento. (id., p.142)

O desenvolvimento na fase de aquisição é marcado pela emergência gradual de funções psíquicas internalizadas, fomentando a consciência da própria identidade.

\section{b) Nível especializado de desenvolvimento - consciência interpretativa}

No decorrer do processo de aprendizado, o desenvolvimento segue em direção à especialização e, paralelamente, a consciência deixa de enfocar o registro das operações necessárias à performance para atentar sobre os significados, tornando-se interpretativa. Não que os significados das ações fossem negligenciados anteriormente; contudo, não consistiam ainda numa rede de significação, que passa a ser formada nessa segunda etapa 
do processo.

O nível da especialização incrementa um modo específico de adaptação para lidar com as tarefas intrínsecas ao campo profissional escolhido. Todas as escolhas pessoais, em direção à identidade profissional, são fatores de absoluta relevância na profissionalidade. "O mais poderoso e dinâmico desenvolvimento que emerge desta interação entre as escolhas é a tendência de tornar cada vez mais forte o vínculo entre características pessoais e demandas ambientais" (id., p.143), uma correspondendo a outra - e vice-versa - numa via dupla, pois enquanto o ambiente social modifica as características pessoais, cada indivíduo, por sua vez, tende a selecionar para si aquilo que do ambiente social é consistente com suas características pessoais.

Nesse processo, o estilo de aprendizagem se formula e se modela ao mesmo tempo em que governa a transação (interação) com o ambiente, definindo também uma individualidade estável.

A consciência de si mesmo é sobretudo definida sob parâmetros de conteúdos: coisas que posso fazer, experiências que já tive, defeitos e qualidades que possuo.

\section{c) Nível integrado de desenvolvimento - consciência integrativa}

$\mathrm{Na}$ teorização kolbiana, somente quando o desenvolvimento se desloca para a integração, alcançando o nível holístico, torna-se possível integrar conscientemente as diversas ações, operações e significações numa mesma estrutura.

O integrativo é o estágio mais complexo do desenvolvimento, respaldado na segurança trazida da capacidade de o indivíduo reconhecer as próprias competências e, por outro lado, na necessidade de modificar-se, particularmente pela consciência, sobre aspectos de si mesmo que julga importante alterar, aprimorar, transformar ou mesmo se destituir.

É, portanto, um nível marcado pela confrontação existencial, pessoal. A pessoa dirige a atenção para si, avaliando-se; torna-se objeto de investigação. Tal condição pode ser precipitada durante e paralelamente à própria especialização ou ser desencadeada por uma experiência dramática. Algumas pessoas podem nunca chegar a esse grau de desenvolvimento, por estarem imersas no enquadre social, num sistema hermético ou cristalizado, sem que seja criada a necessidade de avalizar sua atuação.

Cada nível do desenvolvimento é caracterizado pela constituição de estruturas continuamente mais complexas de consciência. 0 adulto pode dispor de todos os três níveis de consciência: identificadora, interpretativa e integrativa. Essas estruturas disponíveis de consciência orientam o processo de aprendizagem, que se concretiza pela reflexão a partir 
da experiência. Tanto a caracterização da experiência quanto a seleção de elementos que podem ser extraídos dela dependem do nível de consciência interposto no momento em que se realiza 0 aprendizado.

Cada estágio do desenvolvimento maturacional é caracterizado pela conquista de um nível estrutural de consciência superior ao do estágio precedente, embora se mantenham reminiscências dos primeiros níveis de consciência... Tais estruturas de consciência governam o processo de aprendizagem estabelecido pela experiência, por meio da seleção e definição do que se experiencia. Em termos de desenvolvimento de diferenciação e integração, os processos elementares de aprendizagem são os meios primários de diferenciação da experiência; as combinações dessas formas elementares numa ordem superior representam a pressão integrativa do processo de aprendizagem. 0 foco consciente da experiência, que é selecionado e formado pelo nível pessoal de desenvolvimento real, é refinado e diferenciado na zona de desenvolvimento proximal, apropriando-se dela e a transformando. (id., p.146)

Os fundamentos kolbianos indicados acima anunciam que uma única experiência é capaz de promover aprendizado nos diferentes níveis, desde o aquisitivo até 0 integrativo. Hipoteticamente, mudanças de maior magnitude seriam acarretadas pelo gerenciamento integrativo dos processos cognitivos envolvidos na reorganização e generalização conceitual sobre aspectos não totalmente inéditos, elementos e características já conhecidos ou experienciados. Outros - apesar de desconhecidos, mas reconhecidos como familiares pela semelhança com saberes e operações mentais constituídos - teriam um tratamento em nível especializado. Finalmente, aqueles que representam modos de atuar na realidade e conhecimentos completamente novos poderiam também ser apreendidos, embora num nível aquisitivo de consciência. Na realidade, é incomum a confluência dos três níveis de consciência em uma mesma experiência, sempre havendo dependência de múltiplos fatores, tais como o potencial de desenvolvimento da pessoa envolvida na experiência, os requisitos necessários para vivenciá-la, o envolvimento afetivo com o tema, as condições de aprendizagem, entre outros diretamente relacionados aos níveis de consciência que se formaram para aquele indivíduo, implicados em saberes e aprendizagens desenvolvidos ao longo de sua história. Por isso, Kolb reporta-se à zona de desenvolvimento proximal, conceito vygotskiano definido tanto por desenvolvimento real quanto por desenvolvimento potencial.

Analogamente, não há homogenia da consciência implicada numa experiência de aprendizagem, assim como uma pessoa não tem desenvolvimento homogêneo, nem em nível real, nem em potencial. A cada nova situação de aprendizagem há múltiplas zonas de desenvolvimento em processo, bem como se presentificam níveis distintos de consciência. 


\section{3 - Modalidades de Aprendizagem}

Kolb descreve de maneira sistemática o processo da aprendizagem experiencial, propondo um modelo explicativo das estruturas subjacentes ao processo de aprendizagem com raízes na Psicologia, Filosofia e Fisiologia.

Esse modelo é estrutural por estabelecer diferentes estilos de aprendizagem e determinar que cada estilo possui uma estrutura correspondente com a qual se processa a apropriação e a elaboração de conhecimentos.

Ao longo da história, podemos encontrar diferentes autores que refletem sobre o papel da experiência na aprendizagem. Dentre as concepções erigidas, encontramos a defesa acirrada e dicotômica, ora do papel da teoria ora da prática. Numa visão integradora da teoria com a prática, 0 americano David Kolb (1984) apresenta sua perspectiva esclarecedora do que designou de Aprendizagem Experiencial, assentada na articulação em duas dimensões opostas: a dimensão do concreto/abstrato e do ativo/reflexivo... No bojo de sua conceitualização, Kolb resolve a tensão entre estas dimensões por meio de duas operações mentais: a preensão da experiência e a sua transformação. A aprendizagem experiencial consiste, desse modo, na compreensão e na transformação (metamorfose) da experiência. (Finger, 1989 apud Alarcão, 2002: 226, grifos nossos)

Essa perspectiva sugere a aprendizagem experiencial na educação, nos sistemas organizacionais e no processo conhecido como life long learning, identificado a partir das posições teóricas que defendem ser a aprendizagem um processo a ocorrer durante toda a vida do indivíduo.

Da relação entre aprendizagem - conhecimento - desenvolvimento, a estrutura da Aprendizagem Experiencial define-se pela integração de quatro modelos adaptativos, originários da relação entre estágios que, embora assim denominados, de nenhum modo conotam uma evolução crescente entre eles, de uma etapa a outra, pois são efetivamente cíclicos. Desse modo, o ciclo da aprendizagem experiencial está emoldurado por quatro modelos de aprendizagem:

1 - EXPERIÊNCIA CONCRETA (EC)

Experiências pessoais de contato direto com a realidade, com os dilemas a resolver. A ação atual referencia-se em conhecimentos e processos mentais já existentes, aprendidos em outras ocasiões. A Experiência Concreta fornece a matéria-prima para as aprendizagens ulteriores.

\section{2 - OBSERVAÇÃO REFLEXIVA (OR)}

Pesquisa sobre a realidade. Busca por identificação, associação, agrupamento entre os 
fatos perceptíveis da experiência vivida. Identificação das características, das dificuldades e escolhas. Partilha de opiniões sobre um determinado assunto. Movimento interno, de reflexão.

\section{3 - CONCEITUAÇÃO ABSTRATA (CA)}

Formação de conceitos abstratos e generalizáveis sobre a experiência a partir da reflexão que dela se fez. Explicação de realidades semelhantes. Generalização de regras e princípios. É a síntese de um debate ou da troca de opiniões, que se caracteriza pelo estabelecimento de um tronco comum de idéias compartilhadas.

\section{4 - EXPERIMENTAÇÃO ATIVA (EA)}

Aplicação prática dos conhecimentos e processos de pensamento tornados refletidos, explicados e generalizados. Reflete-se em experiências inéditas. Ação centrada em relações interpessoais, na colaboração e no trabalho em equipe. Movimento externo, de ação.

Em pares, esses modelos formam uma nova camada, traduzida em dimensões não de aprendizagem, mas de desenvolvimento. Cada dimensão representa uma das posições dialéticas do processo de aprendizagem, ou seja, tanto seus elementos internos quanto a relação de uma com a outra sempre demanda articulação. Uma dessas dimensões, a de preensão, é caracterizada pela relação entre concreto e abstrato. A outra, de transformação, articula ação e reflexão.

Vejamos, então, em que se fundamentam as duas dimensões e quais seus componentes intrínsecos:

1. A dialeticidade da relação entre concreto e abstrato é corporificada na aprendizagem por preensão, através da combinação entre experiência concreta (1 - EC) e conceituação abstrata (3 - CA).

De acordo com a terminologia do autor, aprendizagem por preensão é aquela que estabelece dois processos opostos para comunicar a experiência, reportar-se a ela e compartilhá-la:

1.1. o de apreensão: é tangível pela experiência imediata, ou seja, pela aprendizagem extremamente vinculada à experiência concreta, de natureza mais intuitiva e instantânea, derivada sobretudo da percepção, exemplificação e imitação. Para Kolb, apreender é um ato circunscrito pela apreciação da experiência imediata, determinado pela atenção, valoração e afirmação. 
1.2. o de compreensão: reflete interpretações conceituais e representações simbólicas, ou seja, uma aprendizagem direcionada pela conceituação abstrata, de natureza mais refletida e distanciada, que permite a formação de imagens mentais. Compreender criticamente os significados da experiência é um processo baseado na objetividade da análise, "um processo dialético integrando experiência e conceitos, observações e ação" (Kolb, 1984: 22).

Apreensão apreciativa e compreensão crítica são processos igualmente fundamentais na (re)construção e produção de conhecimentos, cuja finalidade é o desenvolvimento complexo e integrado.

2. A dialeticidade da relação entre reflexivo e ativo é corporificada na aprendizagem por transformação, através da combinação de observação reflexiva (2 - OR) com experiência ativa (4 - EA).

$\mathrm{Na}$ transformação, os processos opostos se referem à representação simbólica da experiência do sujeito em relação a si mesmo:

2.1. o da intenção (ou interiorização psíquica): pela reflexão interna - intencional, consciente e determinada por processos mentais de auto-avaliação. Trata-se de uma aprendizagem transformada e transformadora das operações mentais. A intenção é um ato consciente e voluntário, cujo caráter metacognitivo determina mudanças na estrutura e no funcionamento psicológico.

2.2. o da extensão (ou exteriorização social): pela ação no mundo exterior em interação com outras pessoas, ou seja, aprendizagem pela própria ação. A extensão é pragmática por excelência, pois somente ao retornar à experiência pode-se colocar à prova o que se observou, hipotetizou e conceituou de experiências anteriores.

Da mesma forma que a dialeticidade entre Experiência Concreta e Conceituação Abstrata (referenciadas em conhecimentos concretos e abstratos), formula a preensão integrativa; essas duas últimas formas (referenciadas em operações mentais de reflexão e ação), resultantes da dialeticidade entre Observação Reflexiva e Experiência Ativa, são igualmente complementares e imprescindíveis nos processos psicológicos envolvidos no desenvolvimento.

O diagrama abaixo retrata o modelo de aprendizagem experiencial, ressaltando 0 movimento dialético e cíclico entre as quatro dimensões de aprendizagem. 


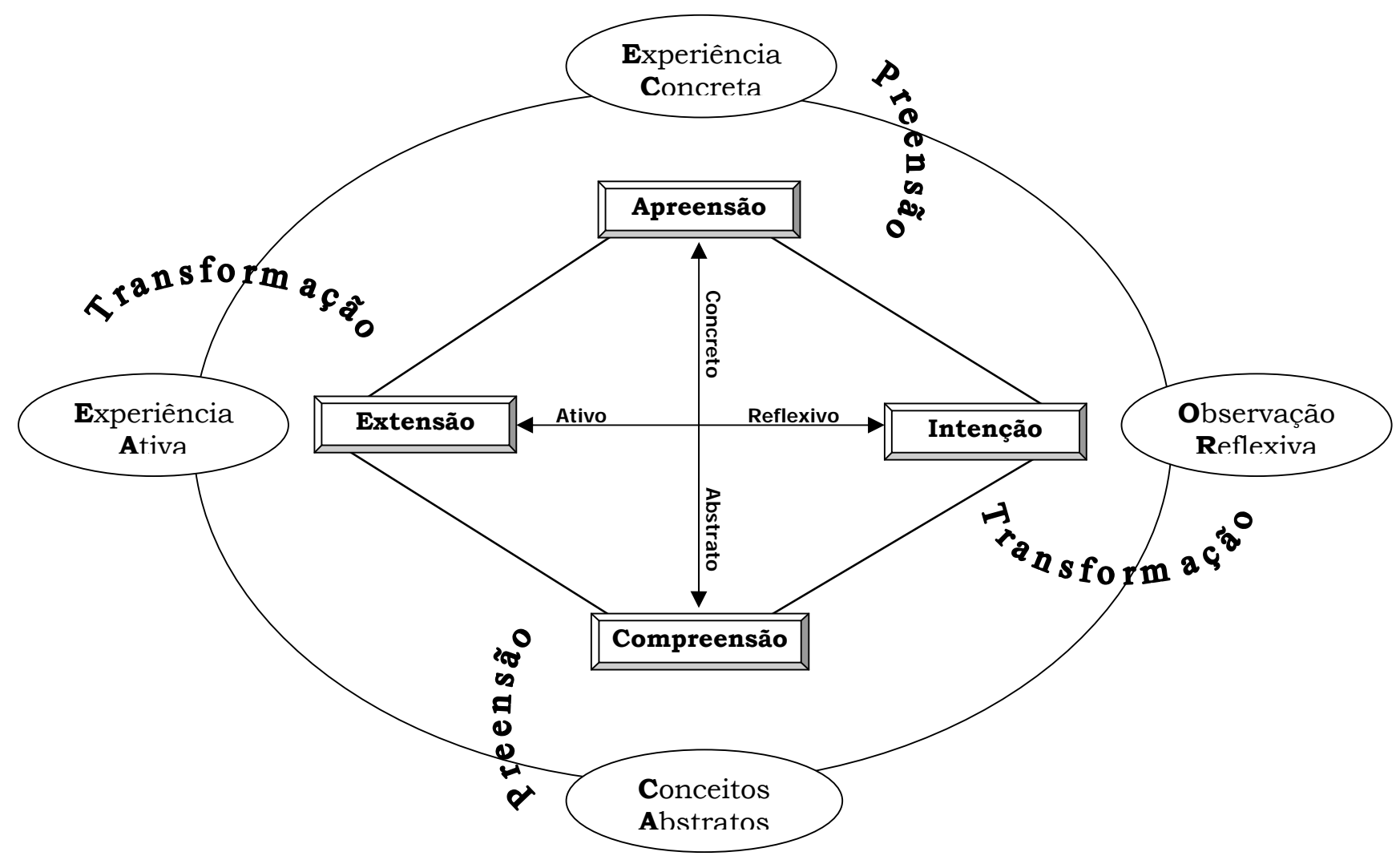

Figura 3.1 - Ciclo de Aprendizagem Experiencial ${ }^{26}$

A figura representa o Ciclo de Aprendizagem Experiencial. Do centro para o exterior, as setas entrecruzadas indicam as duas dimensões que unem ação prática e teorização (relação entre desenvolvimento e aprendizagem); as inscrições côncava/convexa e verticalizadas referem-se aos sistemas de pensamento; nas molduras retangulares identificam-se as quatro facetas do desenvolvimento e, por fim, nas molduras ovaladas estão indicadas as quatro modalidades de aprendizagem.

De acordo com esse autor, os pontos cruciais (EC - experiência concreta; OR observação e reflexão; CA - formação de conceitos abstratos; EA - testagem das hipóteses e conceitos formulados em situações novas) definem ciclicamente vínculos entre experiência vivida, construção de conhecimento e projeção de experiências futuras, resultando em formas diferenciadas de intervir na realidade.

O ciclo quadrifásico de Aprendizagem Experiencial pode ser iniciado em quaisquer das quatro modalidades elementares de se efetuar o aprendizado, aproximando-se da imagem de uma espiral contínua. Há, porém, maior incidência de o sistema iniciar pela experiência concreta, pela qual seguem as observações sobre as condições da experiência, sua meta e

\footnotetext{
${ }^{26}$ O diagrama apresentado é uma adaptação do original, elaborado por Kolb (1984: 42).
} 
as ações erigidas. Nessa etapa, o exemplo particular é compreendido, de modo que o exame e a seleção das mesmas ações em circunstâncias semelhantes viabilize antecipar novas experiências e projetar ações plausíveis. Em seguida, o processo de aprendizagem focaliza a descoberta de princípios gerais a fim de propiciar explicações não apenas sobre o exemplo particular, mas a elaboração de hipóteses conclusivas sobre situações com características semelhantes. Os conhecimentos e desenvolvimento resultantes alicerçam o último pólo do ciclo - da experiência ativa - pela qual se renova o ciclo de modo ascendente e continuamente. -

Conforme explicitamos, os processos mentais e as ações na prática se articulam em cada um dos momentos da aprendizagem. Pela ênfase num ou noutro processo mental e num ou noutro modo de atuar na prática, Kolb elaborou outras combinações, destinadas especificamente a caracterizarem diferentes modos de aprender. Uma pessoa pode engendrar sua aprendizagem mais pela renovação experiencial a partir da reflexão que realiza sobre o observado; outra, pela necessidade de articular observações com conceitos; outra, ainda, opta por sistematizar conceitos e experienciá-los.

Essas distinções representam estilos de aprendizagem. Há, geralmente, um estilo que prepondera, embora cada ser singular não tenha somente um estilo de aprendizagem. Há, igualmente, ao longo da vida, mudanças de estilo para uma mesma pessoa. E, finalmente, também se alternam os estilos em função da variação de situações de aprendizagem a serem defrontadas, sendo imperativo que o estilo seja o mais apropriado para se ajustar ao que é requerido e às condições que determinam cada nova experiência de aprendizagem.

As combinações de estilos estruturam de modo mais contundente o funcionamento das modalidades de aprendizagem. Com isso, a sucessão entre os três níveis de desenvolvimento de complexidade integrativa e diferencial - equivalentes a desenvolvimento aquisitivo, especializado e integrativo - respaldam-se na articulação entre dois os mais modos de experienciar a aprendizagem.

Utilizaremos as descrições bem como uma exemplificação de Kolb para tratarmos das combinatórias entre experiência concreta, observação reflexiva, conceituação abstrata e experiência ativa.

A base em que as combinações se apóiam é determinada pelo contraste entre processos de preensão e processos de transformação do conhecimento.

Ao explicarmos e apresentarmos figurativamente o Ciclo de Aprendizagem Experiencial, esclarecemos que essas duas dimensões são compostas de apreensão e compreensão, por um lado, e de intenção e extensão, por outro.

Enquanto o papel de comunicar e compartilhar a experiência cabe à apreensão e à 
compreensão, intenção e extensão têm a finalidade de auxiliar para que o sujeito formule para si próprio significações sobre a experiência.

Esses conceitos não fazem sentido sem que estejam conectados uns aos outros. É justamente esta a característica básica das combinações. Uma combinação é sempre constituída de um dos processos de preensão com um dos de transformação. Assim, apreensão e compreensão são transformadas ora por intenção, ora por extensão:

a) apreensão transformada por extensão;

b) compreensão transformada por extensão;

c) apreensão transformada por intenção;

d) compreensão transformada por intenção.

Essas quatro combinações são denominadas elementares, pois a associação ocorre entre dois componentes. Kolb menciona que as combinações de três elementos (por exemplo, compreensão/apreensão transformadas por extensão), denominadas formas superiores de aprendizagem, surgem somente no nível integrado do desenvolvimento. Para os fins de nosso estudo, torna-se desnecessário e dispendioso abordar as combinações de nível integrativo, pois exigiria conceituarmos aspectos da teoria que transcendem a realidade da própria experiência formativa realizada ${ }^{27}$.

Vejamos como Kolb descreve o funcionamento das combinações elementares.

a) Apreensão transformada por extensão:

Essa relação implica em apreender a experiência concreta (EC) balizando-se na experiência ativa (EA).

Por meio da projeção da experiência futura transcorrem as mudanças na apreciação perceptual da experiência atual, sua apreensão.

O foco não é o conhecimento conceitual. São os julgamentos e a construção de valores pessoais que qualificam o interesse pela que se experiencia.

Ao pensarmos sobre algumas das sensações deflagradas numa situação envolvente, expressas por articulações gestuais e/ou oralmente, tornamo-nos mais cônscios do que nos agrada ou não, do que nos causa repulsa, incômodo e do que pretendemos experienciar novamente.

Estão em jogo as características observáveis da situação concreta. A pessoa se fia numa

${ }^{27}$ Cf. Jarvis (1995), estudioso que sugere críticas à definição e aplicação dos estilos de aprendizagem propostos por Kolb, que integram as definições sobre as combinações superiores. 
intuição global e nas sensações que the causam os dados da realidade. Nesse caso, a apreensão ocorre como prévia de ação. Pequenos ajustes são feitos em decorrência do que se acredita ser a 'direção certa a tomar', mais por convicção do que por fundamentos teóricos.

O fato de ser uma combinação elementar de modalidades não determina que seja de nível inferior, já que a experiência ativa dá sustentação às operações mentais para apreender. Assim sendo, a apreensão é dirigida por previsão, propiciando o planejamento e a criação de hipóteses a partir das observações palpáveis que se respaldam na concretude da experiência antecedente.

b) Compreensão transformada por extensão:

A combinação é formada novamente pela experiência ativa (EA) que, agora, alicerça a conceituação abstrata $(\mathrm{CA})$. O caráter prospectivo se mantém, tal como na combinação anterior.

Compreender refere-se à construção de conceitos e à extensão, ou seja, exteriorização de aprendizagens, à experimentação desses conceitos em novas situações.

Nessa combinação, um modelo abstrato ou teórico é utilizado para avaliar a atuação prospectivamente, com a finalidade de predizer metas.

A extensão prepondera sobre a compreensão, modificando e reorganizando os conceitos necessários para se compreender uma situação de aprendizagem específica, real, mas ainda não concretamente realizada.

A implicação entre as modalidades de aprendizagem finaliza ao se colocar à prova os conceitos reformulados, ampliados e generalizados, isto é, quando eles retornam à atuação prática, experimentalmente.

O preparo para avaliações e exames escolares ilustra a compreensão via extensão.

c) Apreensão transformada por intenção:

Essa estratégia de aprendizagem configura-se por experiência concreta (EC) e observação reflexiva (OR).

A composição por intencionalidade exerce um papel menos óbvio que a extensão, ou exteriorização, porque está orientada para o sujeito que aprende, e não para o plano interpessoal. Intenção simboliza um aprendizado que se realiza por força dos processos metacognitivos de avaliação da experiência concreta.

Especialmente por não se evidenciar, a observação reflexiva coordena a apropriação da experiência. Torna-se imprescindível extrair dedutivamente a reflexão. As imortalizadas 
investigações de Sherlock Holmes, o agente da Scotland Yard, chegavam ao desfecho sobre os crimes sempre por dedução.

Deduzir, embora não capturável concretamente, é um meio de se transformar a maneira de refletir sobre a experiência, modificando as observações feitas a partir da mesma e, em última instância, apreendendo.

Uma das formas mais comuns da apreensão transformada via intenção ocorre quando se almeja um determinado objetivo e, para alcançá-lo, imita-se o comportamento de outra pessoa que obteve sucesso no mesmo empreendimento.

d) Compreensão (CA) transformada por intenção (OR):

As modalidades envolvidas são, respectivamente, conceituação abstrata (CA) e observação reflexiva (OR).

Se a formulação de conceitos abstratos via extensão é sobejamente pragmática, orientando-se pela testagem de hipóteses na experiência ativa, no caso em questão as mudanças da conceituação são inferidas por meio da indução. Induzir é um raciocínio lógico presente na reflexão intencional. Sua relevância reporta-se à capacidade de ampliar o observável concreto.

Parafraseando Kolb, as intenções precedem as inferências. Assim, as reflexões intencionais orientam a compreensão para que os conhecimentos sejam aprofundados, ganhem abstração e generalidade, algo que não poderia se efetuar com o mesmo grau de refinamento mediante a imposição pragmática da experiência ativa.

Em termos gerais, podemos dizer que a pesquisa científica respalda-se mais enfaticamente nesta composição de modalidades. Mesmo quando balizada e, ao mesmo tempo, endereçada à prática, a teorização impõe ao investigador uma observação sedimentada na reflexão.

As combinações foram didaticamente discutidas em separado, e para cada uma indicamos um exemplo ilustrativo. Não nos alongamos em detalhá-las nem em explicitar outras relações entre modos de aprender que seriam cabíveis a quaisquer das exemplificações. Entretanto, seria incorreto imaginarmos que, por exemplo, todo o preparo para um exame escolar se respaldaria somente em compreender os conceitos com vistas a externá-los posteriormente. Ao estudar, a pessoa inteira está envolvida na atividade. Seu estado afetivo, envolvimento com os propósitos do estudo, percepções e observações, ponderações de caráter dedutivo e indutivo e comportamentos em geral estão todos articulados na aprendizagem. 
Kolb, reportando-se a alguns estudos que realizou, cita o aprendizado de uma língua estrangeira como exemplo ilustrativo das múltiplas facetas do processo de aprendizagem experiencial.

Imaginemos, como Kolb, que uma pessoa inicie sua aprendizagem do francês pela compreensão via intenção (CA-OR). O primeiro contato terá ocorrido a partir de idéias refletidas e capazes de ancorar comparações com a língua materna e interpretar alguns dos fenômenos da língua - como sua estrutura geral - características de construção frasal, elementos ortográficos e fonográficos.

Esse processo de conceituação teórica e observação reflexiva poderá ser conectado com a compreensão por extensão (CA-EA), viabilizando testar empiricamente as primeiras hipóteses firmadas sobre o conhecimento da língua francesa, caminho possível para checar a validade dos processos indutivos antecessores.

Estará recorrendo a três dos quatro modelos de aprendizagem: observação reflexiva (intenção), conceituação abstrata (compreensão) e experimentação ativa (extensão).

Se ainda combinar as hipóteses sobre os efeitos que lhe causa a aprendizagem daquela língua, ou seja, atentar para seus sentimentos e sensações, concretamente percebidos durante a experiência real de aprendizagem (EC-EA), por apreensão transformada pela extensão, as idéias abstratas que terá formado anteriormente se apossam da concretude das emoções, das sensações corporais, dos comportamentos.

Quanto às formas elementares de aprendizagem, tem-se a ação de apreender por intenção (qualificada pela introspecção - EC-OR), a ação de apreender por extensão (qualificada pela extroversão - EC-EA) e a ação de compreender por intenção (CA-OR) e por extensão (CA-EA).

Adicionalmente, temos as formas superiores de aprendizagem, geradas a partir de combinações mais sofisticadas, como EC - OR - CA (A-I-C), apreensão vinculada à via intencional de transformar a compreensão.

Vemos, então, que há modelos distintos de aprendizagem no nível elementar e diferenças de estilo de aprendizagem entre as pessoas quando se trata de realizar as combinações que ascendem ao nível superior de aprendizagem. Em acréscimo, uma mesma pessoa pode recorrer a estilos diferentes em situações diferentes de aprendizagem. Como se deduz, não é fácil traduzir em tipologias os estilos individuais de aprendizagem. Devido a isso, qualificar os estilos em mais ou menos adequados seria ingênuo, equivaleria a negar a complexidade inerente aos processos subjacentes de aprender. 


\section{4 - Integração e Diferenciação}

Distanciando-se de uma perspectiva de universalidade no processo de desenvolvimento, Kolb sublinha enfaticamente que, na Aprendizagem Experiencial, são reconhecidas as diferenças individuais.

A singularidade de cada ser aprendente tem dois ângulos. Um deles, cujo exame é mais freqüente nos estudos sobre a natureza do desenvolvimento, é atribuído à comparação entre indivíduos cujo desenvolvimento profissional é largamente distinto, apesar de similitudes quanto à carreira, idade, formação, etc. 0 outro, ontogênico, está agregado às diferenças entre estágios de desenvolvimento e as que manifestam o curso particular de desenvolvimento (microgênico), pois "em seu estilo particular de aprender a pessoa se desenvolve" (id., p.138). Um estilo é verdadeiramente plural, une simbioticamente vários estilos, e nunca é o mesmo em razão das circunstâncias de aprendizagem e das metamorfoses intrínsecas ao desenvolvimento.

A noção de estilo é relevante em nosso estudo por confluir na relação entre aprendizagem e desenvolvimento. Ambos são inegavelmente exclusivos para cada pessoa.

Reiteramos que aprendizagem implica em desenvolvimento e, paradoxalmente, embasase num desenvolvimento que é potencial e retrospectivo sincronicamente. Mas o que significam essas duas assertivas?

Em primeiro lugar, sabemos que na teoria kolbiana aprender e desenvolver são processos interdependentes e inerentes à constituição do homem. Mais que isso, são transitórios por estarem balizados em conhecimentos e modos de atuar que, ao se tornarem próprios ao indivíduo, potencializam o surgimento de novos saberes.

Em segundo lugar, o enlace dialético da aprendizagem com o desenvolvimento evoca novos meios de solucionar problemas e relações inéditas entre conhecimentos. Antes mesmo de se averiguar a existência de domínios consolidados, o desenvolvimento consubstancia a aprendizagem exatamente por ser preciso (re)criar meios de lidar e compreender o mundo e colocá-los à prova.

Sob esse prisma, uma experiência de aprendizagem pode ser apropriada de diferentes maneiras, em função do desenvolvimento:

1) Redundar simplesmente em desconforto, perplexidade ou sensação de puro prazer;

2) Instigar a observação de alguns de seus componentes ou propriedades;

3) Suscitar questionamentos e gerar reflexões;

4) Reivindicar a gestação de processos de pensamento, não disponíveis antes.

Tais conseqüências não se alinham somente à especificidade da experiência 
(metas/condições), pois o desenvolvimento guarda igual relevo na geração de resoluções e conhecimentos.

A completa compreensão desse fenômeno consiste em situarmos duas forças simultâneas do funcionamento psicológico: integração e diferenciação, adjetivadas por Kolb como Integração Hierárquica (hierarchic integration) e Diferenciação Crescente (increasing differentiation). Esses dois conceitos são fundamentais, virtualmente, para todas as teorias sobre desenvolvimento cognitivo no adulto.

A diferenciação é composta pelo movimento em dois sentidos: a) crescimento de complexidade da unidade e interdependência entre as partes. O curso da aprendizagem e desenvolvimento é de refinamento, discriminação e elaboração de categorias de experiência, bem como de variedade de comportamentos quando ao mesmo tempo se firma a interdependência funcional em torno das partes separadas. A integração pode ser compreendida como uma escala hierarquizada, com níveis múltiplos, que se modula de acordo com a complexidade e a difusão causada pela diferenciação cada vez mais incrementada.

O primeiro nível dessa escala integrativa e diferenciadora corresponde a regras simples e mais ou menos fixas para organizar as dimensões diferenciadas da experiência num caminho absolutista, como se houvesse somente um possível. Por exemplo, classificar as experiências como boas ou más.

Num determinado momento, uma regra alternativa emerge e passa a reger a interpretação das situações. 0 absolutismo certo-errado torna-se um pouco mais flexível pelo uso de pensamentos simples e contingenciais. Passam a coexistir duas formas de interpretação: a do nível anterior - extremamente absolutista e inflexível - e a da interpretação alternativa. Paulatinamente, o absolutismo e a inflexibilidade são substituídos pela relatividade e flexibilidade.

No nível seguinte, regras mais complexas que a do pensamento simplesmente contingente são desenvolvidas, determinando uma visão perspectiva da experiência. Essas regras são mais "internalizadas", livres da aplicação baseada na experiência passada ou nos estímulos externos.

O mais alto nível de integração adiciona um outro sistema de regras que forma uma estrutura para generalidade muito complexa das interações, propiciando grande flexibilidade na integração e organização da experiência, tornando possível lidar com mudanças e incertezas ambientais por meio de desenvolvimento de construções alternativas complexas acerca da realidade.

Estes quatro níveis de integração hierárquica são caracterizados de acordo com a 
capacidade de encontrar relações alternativas, criando novas perspectivas, cujas regras sejam cada vez mais flexíveis para dar conta de uma gama maior de situações, acontecimentos, idéias, etc, presentes na realidade experiencial.

Através da integração hierárquica, o indivíduo formula caracterizações e especificidades, pois tal integração modula-se em um esquema que organiza e controla o processamento de subordinações e diferenciações dos conceitos, sentimentos, atos e observações. No exemplo em que se situa o desenvolvimento emocional, o refinamento das emoções também se refere à discriminação tanto de situações como de pessoas, estabelecendo continuidade e significação para a própria experiência. A unidade e a consistência da experiência se processam, no decorrer do percurso, entre a indiscriminação e a integração organizacional. Decorrem desse percurso dois aspectos fundamentais para maior complexidade de pensamento: o incremento da consciência e a sofisticação do controle sobre si mesmo para atuar com seu entorno.

O desenvolvimento consolida-se à medida que a integração se torna complexa e que a diferenciação se amplia. Ambos os movimentos se dirigem à constituição de um único eixo, mediante quatro dimensões: complexidade afetiva, complexidade perceptiva, complexidade simbólica e complexidade comportamental.

Por conseguinte, essas dimensões de desenvolvimento ensejam a sofisticação das modalidades de aprendizagem a elas arraigadas. Em decorrência, as modalidades de aprendizagem experiencial estipulam mudanças internas em direção a novos níveis de desenvolvimento.

Essa dialética enaltece 0 fato de que nem as dimensões nem as modalidades (ou estruturas, como alude Kolb em alguns casos) tornam-se mais complexas, independentemente uma da outra. É vital, portanto, que se articulem reciprocamente, determinando um conjunto íntegro de novos saberes.

As particularidades dos paralelos entre desenvolvimento e aprendizagem definem quatro âmbitos, cada qual correlacionado a uma das modalidades:

\section{a) Aprendizagem Afetiva}

Aprendizagem afetiva se referencia nas interações ocorridas durante a experiência concreta (EA). Ao suscitar amplitude de complexidade em relação ao desenvolvimento afetivo, resulta em nível superior de sentimentos, afetos e valores. 0 movimento que leva à crescente integração afetiva é conduzido "via resolução da dialética entre intenção e extensão" ( $i d .$, p.148).

Amplifica, por exemplo, a compreensão auto-analítica sobre os próprios sentimentos e 
propicia criação de um sistema integrado de valores. Nem toda experiência é predominantemente voltada à aprendizagem afetiva, apesar de algumas serem estritamente endereçadas à complexidade de desenvolvimento afetivo.

\section{b) Aprendizagem Perceptual}

$\mathrm{Na}$ aprendizagem perceptual entra em cena a observação reflexiva (OR). Extrair observações para aprendizagem a partir de uma experiência envolve perceber o todo e suas partes, identificar relações entre as particularidades, caracterizar elementos do conjunto.

A aprendizagem amplia a complexidade da integração perceptiva através de dois mecanismos: apreensão e compreensão, decorrendo num nível superior da habilidade de observar.

Ao discorrer sobre esse tema, Kolb ressalta que a percepção pela observação contrasta com níveis perceptivos primários, ilustrando esta diferenciação a partir do fenômeno conhecido como percepção ilusória que, por exemplo, pode ser causada pela simples inversão das flechas nas extremidades de uma linha reta:

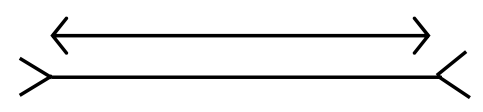

A observação reflexiva distancia-se da percepção ilusória (fusão entre real e imaginário) por se pautar no raciocínio lógico pelo qual a ilusão óptica é desmascarada.

Nos termos de Kolb, a percepção vinculada à observação se presentifica até mesmo nos ensaios do tipo 'tentativa-e-erro'. Muitas vezes, o adulto recorre a esse gênero de ação ao enfrentar uma situação completamente nova, com um problema para o qual ainda não tenha solução. Por exemplo: no tangran, seguindo o modelo de uma determinada figura, unir suas sete peças para reproduzi-la sem que esta experiência tenha sido realizada antes. Nesses casos, a observação de condições da situação assegura que determinadas formas de agir sejam intuídas a fim de auxiliarem em sua resolução.

c) Aprendizagem Simbólica

Através da conceituação abstrata (CA) a complexidade da aprendizagem simbólica, produzindo significações à experiência vivida, gera formulação e compreensão de conceitos cada vez mais integrados uns aos outros num único sistema.

Um sistema de conceitos pode ser ampliado tanto vertical quanto horizontalmente. Um típico exemplo é o da classificação conceitual: homem está para orangotango assim como 
uma bromélia está para uma margarida. Homem e orangotango pertencem ao reino animal, assim como bromélia e margarida pertencem ao reino vegetal. Homem e bromélia são seres vivos. As relações entre conceitos são múltiplas. Postular significados mais ou menos abrangentes e precisos - nas palavras de Kolb, hierarquicamente integrados e complexicamente diferenciados - exige resolver a tensão entre dois movimentos contraditórios: 0 de extensão e o de intenção.

Todo conceito é mutável e relativo, o que torna impraticável completá-lo. Ao longo do processo de desenvolvimento, a análise das experiências se altera, determinando a construção de significados tanto mais descontextualizados quanto mais generalizados, princípios gerais que ampliam o cabedal de conceitos. Não se trata mais de levantar hipóteses, mas de investigar sua coerência e efetiva viabilidade para formular conceitos plausíveis a novas situações de aprendizagem semelhantes às vivenciadas.

d) Aprendizagem Comportamental

A aprendizagem comportamental ocorre pela experiência ativa (EA) que deflagra aumento na complexidade da atuação na prática, resultando num nível superior da capacidade de agir no mundo "através da resolução da dialética entre compreensão e apreensão... Os comportamentos são guiados e refinados pelo contraste entre o objetivo (definido por compreensão) e a experiência atual (definida por apreensão)" (ibid).

Essas quatro 'resultantes' em desenvolvimento não têm nenhum caráter progressivo ou uniforme, são

todas inter-relacionadas num processo holístico de aprendizagem. A 'recognição' de uma dimensão ajuda a explicar certos fenômenos de desenvolvimento que são tidos como anomalias... (Por exemplo), o caso da percepção fisionômica... Em que percepção e sentimento estão fundidos. Isso é característico para a criança pequena, mas também é visto no desenvolvimento do artista. (id., p.139)

Kolb enfatiza que os níveis de complexidade são múltiplos e variáveis tanto quanto são os conhecimentos do mundo e os acessos de cada ser humano para se envolver em experiências com tais conhecimentos.

O desenvolvimento em cada uma dessas dimensões prossegue de um estado de embevecimento, defesa, dependência e reatividade para o estado de auto-realização, independência, pró-atividade e significações que o próprio sujeito dá. Este processo é marcado pelo aumento em complexidade e relativismo no modo de compreender o mundo, a si mesmo e as próprias experiências no/com o mundo, e por integrações em níveis superiores do conflito dialético entre as quatro modalidades preliminares (básicas) de aprendizagem. (id., p.140, grifos nossos) 
No início do desenvolvimento, o progresso de cada uma dessas quatro dimensões pode ocorrer com relativa independência das demais. Pode haver, por exemplo, um domínio muito mais sofisticado de proficiência simbólica em comparação ao campo afetivo.

"O desenvolvimento num modo precipita desenvolvimento nos outros" (ibid.) à medida que se sucedem experiências de aprendizagem e de exercício de criatividade, exigindo um ciclo superior de integração, sendo isso tão verdadeiro para as dimensões simbólica e emocional como para as demais inter-relações.

\section{Síntese das modalidades}

Em síntese, a definição de Kolb sobre a aprendizagem implica um processo reflexivo. 0 autor pondera que o refinamento do conceito 'reflexão' exige dois processos básicos: perceber e processar, vinculados respectivamente às dimensões concreta/abstrata e ativa/reflexiva.

Nos termos de Kolb, essas dimensões criam um ciclo de aprendizagem entre a experiência concreta e a ativa experimentação, intercaladas pela observação reflexiva e a conceituação abstrata.

A experimentação é vital no processo de desenvolvimento profissional por estabelecer a relação entre prática e teoria. Com a experiência concreta, idéias, valores, crenças e histórico pessoal de aprendizado são peças de um mesmo tabuleiro em que apreender novos conceitos e maneiras de reorientá-los principia um processo espiral, ascendente e dialético de aprendizagem.

A Observação Reflexiva é a investigação sobre a experiência vivida, em que fazemos uso de processos mentais de dedução hipotética, sendo um movimento voltado para o interior, metacognitivo (denominado por Kolb de 'intencional'). Em contrapartida, é necessário encontrar as respostas e solucionar as hipóteses, o que nos leva ao terceiro movimento, de Conceituação Abstrata. Na conceituação, aprender envolve planejamento sistemático, uso da lógica, desenvolvimento de princípios teóricos mais do que de sentimentos, visando compreender e resolver problemas. Para conceituar, generalizamos, extraímos conclusões que permitem não apenas compreender a experiência precedente mas alcançar novo nível de experimentação. À luz das análises metacognitivas e interpretações abstratas, as hipóteses são testadas num movimento para o exterior ('extensional' ou 'de extensão'). A Experimentação Ativa é a resultante de reorientações da ação, em que "aprender é examinar as hipóteses, experimentando-as, incorporando-as ou modificando-as em função das novas situações de experiência" (id., p.26). Pela ação no real, examinam-se os conceitos formulados e apropriam-se aqueles que efetivamente são capazes de sustentar a prática. 
Reproduzimos, a seguir, o quadro que sintetiza a teoria de aprendizagem experiencial para o desenvolvimento da consciência profissional:

\section{Quadro 3.1 - Teoria da Aprendizagem Experiencial do Desenvolvimento - níveis de adaptação e de estrutura da consciência}

\begin{tabular}{|c|c|c|c|}
\hline \begin{tabular}{|l|} 
Níveis de \\
Diferenciacão
\end{tabular} & AQUISIÇÃO & ESPECIALIZAÇÃO & I NTEGRAÇÃO \\
\hline $\begin{array}{l}\text { Nível de } \\
\text { Profissionalidade }\end{array}$ & Performática & Aprendizagem & Desenvolvimento \\
\hline $\begin{array}{l}\text { Estrutura da } \\
\text { Consciência }\end{array}$ & Identificadora & Interpretativa & Integrativa \\
\hline - Espaço ocupado na vida & Respostas, atos, tarefas & Projetos, ocupações & Carreira, vida, gerações \\
\hline $\begin{array}{l}\text { - Estruturas de } \\
\text { Feedback }\end{array}$ & $\begin{array}{l}\text { Objetivos-dirigidos: } \\
\text { para alcançar metas }\end{array}$ & $\begin{array}{l}\text { Aprendendo como } \\
\text { aprender: para mudar } \\
\text { metas e estratégias }\end{array}$ & $\begin{array}{l}\text { Consciência integrada: } \\
\text { para vincular metas com } \\
\text { uma finalidade de vida }\end{array}$ \\
\hline \begin{tabular}{|l|} 
I ntegração \\
Hierárquica
\end{tabular} & \begin{tabular}{|l} 
Estruturas muito \\
diferenciadas com baixa \\
integração entre elas
\end{tabular} & $\begin{array}{l}\text { Poucas estruturas, mas } \\
\text { com maior } \\
\text { especialização. } \\
\text { Alta integração interna. } \\
\text { Baixa integração entre } \\
\text { estruturas }\end{array}$ & $\begin{array}{l}\text { Desenvolvimento de } \\
\text { estruturas } \\
\text { especializadas e } \\
\text { complementares entre } \\
\text { si. Desde baixa até alta } \\
\text { integração entre } \\
\text { estruturas }\end{array}$ \\
\hline $\begin{array}{l}\text { - Experiência Concreta } \\
\text { e Complexidade Afetiva } \\
\text { - via apreensão }\end{array}$ & $\begin{array}{l}1^{\circ} \text { Sensações e } \\
\text { sentimentos diretos } \\
2^{\circ} \text { Continuidade } \\
\text { sensações e } \\
\text { sentimentos - } \\
\text { emergência } \\
\text { sentimentos estáveis }\end{array}$ & $\begin{array}{l}1^{\circ} \text { Sistema egocêntrico } \\
\text { de sentimentos e valores } \\
2^{\circ} \text { Diferenciação entre } \\
\text { sentimentos e valores } \\
\text { próprios e os de outros }\end{array}$ & $\begin{array}{l}1^{\circ} \text { Apreciação } \\
\text { relativizada de sistemas } \\
\text { de valores } \\
2^{\circ} \text { Compromisso com } \\
\text { valores relativizados } \\
\text { (relativismo quanto a } \\
\text { valores assumidos) }\end{array}$ \\
\hline $\begin{array}{l}\text { - Observação Reflexiva } \\
\text { e Complexidade } \\
\text { Perceptiva - via } \\
\text { intenção }\end{array}$ & $\begin{array}{l}1^{\circ} \text { Atenção } \\
2^{\circ} \text { Observação - } \\
\text { imagens contínuas }\end{array}$ & $\begin{array}{l}1^{0} \text { Reflexão: dando } \\
\text { significados pessoais às } \\
\text { observações } \\
2^{\circ} \text { Criação de esquemas } \\
\text { alternativos de } \\
\text { significação e de } \\
\text { observação }\end{array}$ & $\begin{array}{l}1^{\circ} \text { Apreciação } \\
\text { relativizada de } \\
\text { esquemas diferentes de } \\
\text { significação e de pontos } \\
\text { de vista } \\
2^{\circ} \text { Intenção; escolha de } \\
\text { perspectivas } \\
\text { significativas }\end{array}$ \\
\hline $\begin{array}{l}\text { - Conceituação } \\
\text { Abstrata e } \\
\text { Complexidade } \\
\text { Simbólica - via } \\
\text { compreensão }\end{array}$ & $\begin{array}{l}1^{\circ} \text { Reconhecendo } \\
2^{\circ} \text { Constância objetal }\end{array}$ & $\begin{array}{l}1^{\circ} \text { Operações simbólicas } \\
\text { concretas } \\
2^{\circ} \text { Pensamento formal, } \\
\text { hipotético dedutivo }\end{array}$ & $\begin{array}{l}1^{\circ} \text { Unindo significados } \\
\text { concretos a sistemas } \\
\text { simbólicos } \\
2^{\circ} \text { Encontrando e } \\
\text { resolvendo problemas } \\
\text { significativos }\end{array}$ \\
\hline $\begin{array}{l}\text { - Experimentação Ativa } \\
\text { e Complexidade } \\
\text { Comportamental - via } \\
\text { extensão }\end{array}$ & $\begin{array}{l}1^{\circ} \text { Respondendo às } \\
\text { circunstâncias } \\
2^{\circ} \text { Agindo } \\
\text { intencionalmente em } \\
\text { direção a metas de } \\
\text { curto alcance } \\
\text { (imediatas) }\end{array}$ & $\begin{array}{l}1^{\circ} \text { Alcançando } \\
\text { desenvolvimento de } \\
\text { metas claras e de longo } \\
\text { alcance (prospectivas) } \\
2^{\circ} \text { Assumindo riscos: } \\
\text { formulando metas e } \\
\text { estratégias } \\
\text { intercambiáveis }\end{array}$ & $\begin{array}{l}1^{\circ} \text { Testando hipóteses } \\
\text { experimentais: } \\
\text { mudando metas e } \\
\text { estratégias com base } \\
\text { em resultados obtidos } \\
2^{\circ} \text { Ação responsável: } \\
\text { aceitando a emergência } \\
\text { de situações novas e } \\
\text { desconhecidas }\end{array}$ \\
\hline
\end{tabular}

Fonte: Kolb, 1984: 153. 


\section{4 - ENFOQUE METODOLÓGI CO DO PROCESSO FORMATIVO}

Nossa perspectiva de formação baseia-se em princípios que referendam a noção de professor-investigador, ele próprio capaz de avaliar sua prática. Uma série de pesquisas discute atualmente a forma de gestão do trabalho institucional. A modalidade de docência individual, os cursos de formação em larga escala e a falta de interação entre escola e centros de formação e pesquisa mostram um modelo que prevaleceu durante décadas e que não trouxe benefícios para a qualidade da educação.

No processo formativo emancipatório (Kincheloe, 1997), interlocução e partilha de experiências ganham uma dimensão 'crítica'28 por focalizarem, na prática docente, não apenas seu caráter didático, mas condições institucionais da profissionalidade e de características da identidade pessoal e profissional de cada um dos professores.

O diagrama abaixo ilustra a rede da 'organização aprendente' (Oliveira-Formosinho \& Formosinho, 2001: 56), instaurada ao longo de nosso projeto formativo, cujos parâmetros remetem ao modelo ecológico do desenvolvimento profissional ${ }^{29}$

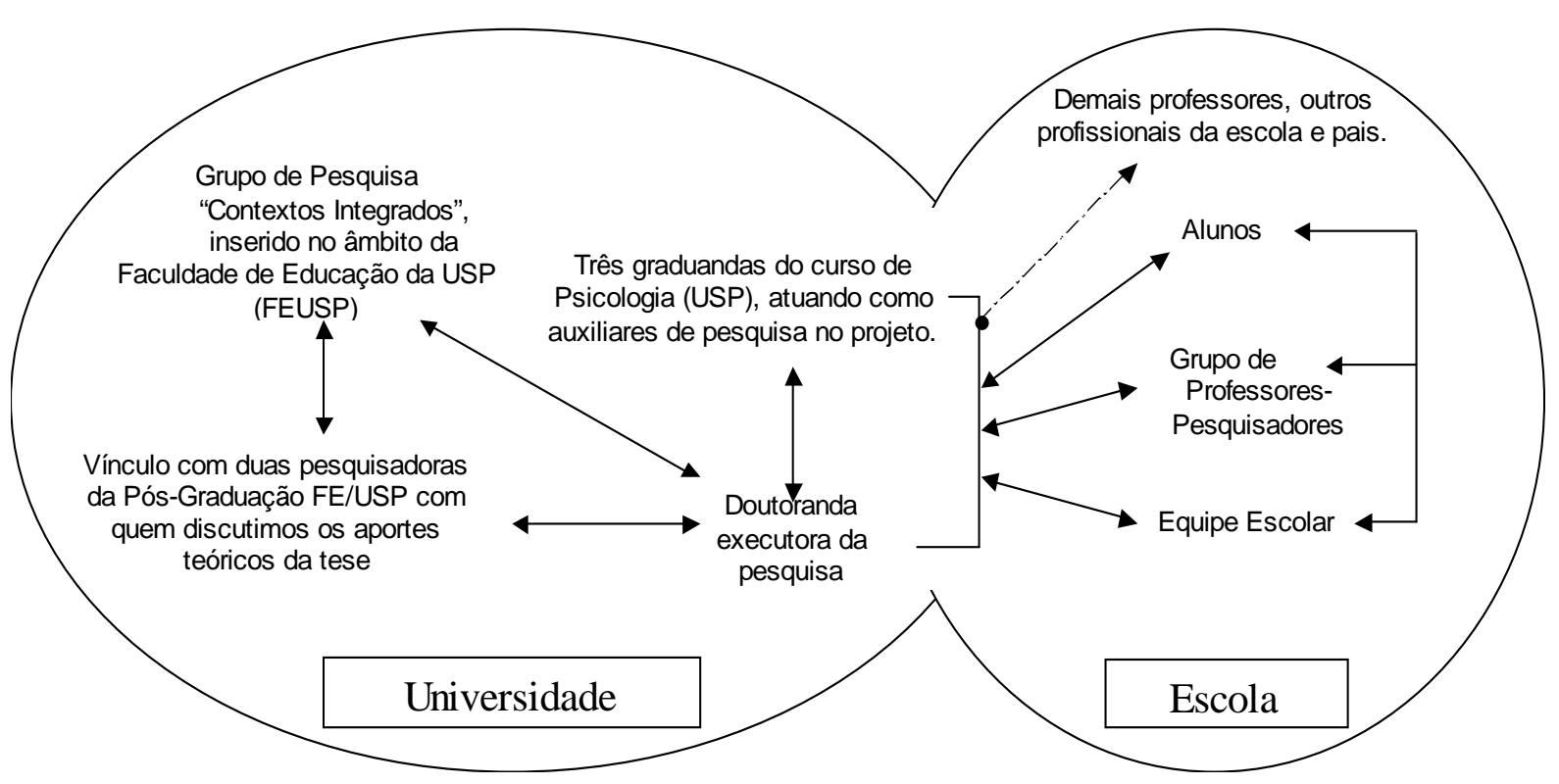

Figura 4.1 - Organização Aprendente

${ }^{28}$ Referência à Escola de Frankfurt, reconhecida pelos ensaios de sociologia crítica às manifestações culturais das sociedades contemporâneas. "Habermas, um de seus autores, exerceu forte influência nas idéias de Schön (...), Elliot e Kincheloe." (Pimenta et al., 2001: 16).

${ }^{29}$ No diagrama, indicamos as inter-relações na realização do projeto formativo. Além dos três segmentos da escola e das auxiliares de pesquisa (graduandas do 40 ano de Psicologia da USP), participamos do Grupo de Pesquisa "Contextos Integrados em Educação Infantil" - que objetiva a formação contextual de pesquisadores ligados à educação infantil e tem apoio científico da Associação Criança de Braga-Portugal - e contamos com a colaboração das Profas. Dras. Marta Kohl de Oliveira e Marina C. M. Dias na elaboração de nosso estudo. 


\section{1 - Descrição da Escola}

Em outubro de 2001, obtivemos uma lista de endereços de escolas junto ao 12 №́cleo de Ação Educativa (NAE-12) $)^{30}$ a fim de definir onde se realizaria a pesquisa de campo.

A escolha da escola foi baseada em dois critérios: a) a proposta corresponder a anseios e interesses do corpo docente com quem atuaríamos e b) a instituição ter horário comum de reunião do corpo docente. Dentre as escolas selecionadas, visitamos quatro, elegendo uma em que as duas condições foram atendidas ${ }^{31}$ e que, adicionalmente, não incluía práticas lúdicas no processo de ensino-aprendizagem.

Em março de 2002, agendamos a primeira visita à instituição. Ao apresentarmos a proposta à direção e à equipe pedagógica, um dos profissionais nos informou que, além do interesse do corpo docente e do horário para realização da pesquisa, a proposta ia ao encontro do Projeto Político-Pedagógico, elaborado no mês anterior. No documento, houve atenção especial à orientação didática, explicitando a necessidade de se consolidar uma diretriz única para a prática docente. Entre as recomendações, ocupou lugar de destaque o uso de jogos educativos, dentro e fora de sala de aula. Contudo, no documento, a visão institucional sobre o tema não foi explicitada. Por fim, propôs-se o estabelecimento de convênios com pesquisadores acadêmicos a fim de estreitar os laços entre os âmbitos escolar e universitário. Esses aspectos aproximaram nossa proposta aos interesses/necessidades do contexto escolar pesquisado, especialmente por indicarem a relevância do jogo educativo - uma inovação desejada e não empreendida até então.

$\mathrm{Na}$ escola, além do período matutino - reservado ao primeiro ciclo do Ensino Fundamental - e do período vespertino - reservado ao Ciclo II - há turmas de alfabetização de adultos à noite. Suas instalações estão em excelente estado de conservação.

No andar térreo ficam as salas da direção e a secretaria, cozinha, copa e refeitório, sala de leitura, banheiros feminino e masculino. Há um tablado para apresentação de peças de teatro e realização de eventos. A porta de entrada dos alunos dá acesso direto a um pequeno pátio coberto. A área externa é composta de quadra poliesportiva e horta. Há também, numa ala isolada, duas pequenas salas de aula provisórias, ocupadas por duas das três turmas de $3^{\mathrm{a}}$ série no período matutino e pelos alunos do Ciclo II à tarde.

Nas diferentes alas da escola, as portas são mantidas fechadas e controladas por profissionais da limpeza ou secretaria, visando impedir a passagem dos alunos ao fundo do

\footnotetext{
30 Órgão que exerce a função de intermediar a relação entre Secretaria Municipal de Educação e uma parcela das instituições de ensino público fundamental da zona oeste paulistana.

${ }^{31}$ Uma das docentes foi nossa aluna na disciplina Psicologia da Educação (oferecida pela FEUSP aos licenciandos da Universidade), fato que, cremos, interferiu na abertura do espaço institucional para nós.
} 
terreno que, mesmo murado, é considerado perigoso (a escola está localizada na intersecção de dois conjuntos habitacionais, onde grupos rivais se alternam em confrontos armados).

Os murais da área do refeitório são constantemente renovados, havendo espaço para avisos, produção de alunos, cartazes de campanhas educativas e informativos dos professores.

A ampla sala de leitura possui estantes que ocupam praticamente toda a extensão das paredes. Mesas redondas e cadeiras, aparelhos de TV e de vídeo e quadro móvel possibilitam aos discentes atividades como assistir a filmes, fazer empréstimos de livros, pesquisar e realizar trabalhos manuais. Apesar da variedade bibliográfica, a disposição aleatória dos livros dificulta o uso eficiente do acervo. Exemplares de literatura atualizada para professores encontram-se empilhados num canto. Uma funcionária é responsável pelo controle de livros emprestados pelos alunos. Excetuando o período de reforma (de julho a meados de agosto de 2002), todos os encontros do projeto foram realizados nesse espaço, também destinado a reuniões pedagógicas e palestras.

No andar superior, há uma sala com dez computadores destinados a aulas semanais de informática. Devido à troca de equipamentos quebrados ou de instalações elétricas, falta do professor ou reforma, o uso desse espaço foi bastante comprometido durante todo o período em que realizamos o projeto.

As salas de coordenação pedagógica e de professores são extremamente pequenas. Por isso, não nos surpreendemos por serem a sala de leitura e a copa os ambientes prediletos de convivência, preparo de aulas, etc. Os coordenadores se esforçam para otimizar o espaço de sua sala, disputado por armários, mesas com cadeiras (uma para cada coordenador ${ }^{32}$ ) e equipamento de informática. Nesse local, são atendidos alunos, pais e professores e são tomadas providências do dia-a-dia escolar.

No mesmo andar estão instaladas sete salas de aula, arejadas, espaçosas e com instalação elétrica para uso de equipamento audiovisual. Na última reforma, houve troca de janelas e esquadrias, que tornaram o ambiente ainda mais confortável e iluminado.

No período matutino, as salas de um dos lados do corredor são ocupadas por duas classes de $2^{\mathrm{a}}$ série, uma de $3^{\mathrm{a}}$ e uma de $4^{\mathrm{a}}$. No lado oposto, estão as duas de $1^{\mathrm{a}}$ série e outra de $4^{\text {a }}$.

Quanto ao funcionamento da escola, há algumas dificuldades que, a nosso ver, originamse na estrutura do sistema educativo, ou seja, derivam das relações da escola com as

\footnotetext{
${ }^{32}$ A coordenadora do Ciclo I permanece na escola nos períodos matutino e vespertino. O coordenador do Ciclo II e do curso de alfabetização de adultos está presente à tarde e à noite. Não raro, atuam conjuntamente, inexistindo uma rígida divisão de funções, o que propiciou mantermos contato com ambos.
} 
regulamentações elaboradas pela esfera administrativa de educação. A rotatividade na composição do corpo docente é a principal. No início do ano letivo e no período de recesso (julho), uma escala de pontuação (por tempo de serviço, nível de formação acadêmica, atividades de capacitação e outros itens) dá aos professores concursados e atuantes prioridade de escolha de turmas vagas, por pedido de licença do professor efetivo ou assumidas por substitutos. Adicionalmente, as alterações nem sempre são imediatas, ocasionando situações paradoxais. Observamos, exemplarmente, uma classe iniciar as aulas com uma professora efetiva; depois, passar algum tempo com uma substituta e finalizar o ano letivo com outra, concursada. ${ }^{33}$

Nessa escola, ao findar o projeto, apenas quatro das nove professoras de Ciclo I pertenciam ao grupo inicial. Das cinco que deixaram a escola, duas se licenciaram e três foram substituídas. As implicações dessa rotatividade no projeto são óbvias. A configuração do grupo formativo alterou-se diversas vezes, e foi necessário lidar com a descontinuidade do trabalho nas classes/turmas em que houve mudança de professora. 0 grupo original contava com onze integrantes (nove do Ciclo I e dois do Ciclo II) para, ao final, contar com a participação integral de apenas quatro das docentes, não coincidentemente as efetivas no cargo, tal como demonstra o quadro abaixo, em que o negrito destaca as duas professoras cujo processo formativo será analisado através do estudo de casos.

\section{Quadro 4.1 - Participantes do Projeto Formativo}

\begin{tabular}{|c|c|c|c|}
\hline $\begin{array}{l}\text { Nome } \\
\text { (Fictício) }\end{array}$ & $\begin{array}{l}\text { Série - } \\
\text { Turma }\end{array}$ & \begin{tabular}{|l|} 
Contrato \\
Institucional
\end{tabular} & $\begin{array}{l}\text { Engajamento no grupo de formação } \\
\text { (grau de participação nos encontros) }\end{array}$ \\
\hline LIA & 1a $-\mathbf{A}$ & EFETIVA & I NTEGRAL \\
\hline Flora & $1 \underline{a}-B$ & Efetiva & Esporádica \\
\hline Cris & $2 \underline{a}-A$ & Efetiva & Parcial (em setembro, saiu em licença-maternidade) \\
\hline Sara & $2 \underline{a}-B$ & Substituta & Esporádica (até setembro, quando deixou a escola) \\
\hline BEL & $3 \underline{a}-\mathbf{A}$ & EFETIVA & I NTEGRAL \\
\hline Val & $3^{a}-B$ & Substituta & Parcial (deixou a escola no final de agosto) \\
\hline Ida & $3 \underline{a}-C$ & Efetiva & Integral \\
\hline Kely & $4 \underline{a}-A$ & Efetiva & Integral (até maio, quando saiu em licença-maternidade) \\
\hline Rita & $4 \underline{a}-B$ & Substituta & Esporádica \\
\hline Gina (P) & Educ. Física & Efetiva & Integral, lecionando para o Ciclo II \\
\hline Zé (P) & Biologia & Efetivo & Integral, lecionando para o Ciclo II \\
\hline Eli (i) & Coordenação & Efetiva & Integral (excetuando o período de suas férias) \\
\hline Ori (i) & Coordenação & Efetivo & Integral nas primeiras duas fases e esporádica nas demais \\
\hline
\end{tabular}

33 Há um volume considerável de pesquisas brasileiras e de outros países em que o cenário político é tema central, visando identificar e planificar mudanças para corrigir distorções como a mencionada (ChantraineDemailly, 1992; André, 1995; Formosinho, 1984; Demo, 1997; Saviani, 1998; Nunes, 2000; Almeida, 1999; Pimenta, 2000). 
Outro problema refere-se a compromissos junto ao NAE ou Secretaria Municipal de Educação, que extrapolam a agenda escolar, impedindo o transcorrer habitual das atividades. Em geral, as soluções encontradas são imediatistas como, por exemplo, dispensa antecipada dos alunos.

Em relação à concepção de ensino veiculada na escola, notamos entre os professores uma crença na baixa capacidade dos alunos, justificada por ambiente sociocultural desfavorável e por pouca orientação familiar. Tal convicção produz resistências ao ensino lúdico. Parte-se do pressuposto de que os alunos não saberão jogar, necessitando de précondições materiais (obtenção de objetos lúdicos), de aprendizagem e principalmente de acentuada diminuição do número discente por classe (em média, composta por quarenta alunos cada uma). Assim, a função ludo-educativa do jogo é praticamente negligenciada, dado que, para ser empreendido, questões essenciais do ensino deveriam ser resolvidas $a$ priori.

\section{2 - Plano Geral de Trabalho}

'Que isto de método, sendo, como é, uma coisa indispensável, todavia é melhor tê-lo sem gravata nem suspensórios, mas um pouco à fresca e à solta, como quem não Ihe dá da vizinha fronteira, nem do inspetor de quarteirão.' (Machado de Assis).

Ao justificar a brusca passagem que faz de sua meninice à sua juventude, o narrador... autoriza-se a fazê-la defendendo que o método, embora coisa indispensável, deve ser tratado com... flexibilidade, sem que se sujeite a rígidas formas de controle exterior.

A digressão metodológica machadiana parece-nos muito inspiradora para explicitar a atitude metodológica que marcou a realização desta pesquisa. Dela guardamos sobretudo a idéia da flexibilidade e do nãopatrulhamento. (Pereira, 1998: 62)

Tomamos de empréstimo as palavras de Maria Izabel Galvão Gomes Pereira porque, tal como em sua pesquisa, foi primordial atentarmos para a flexibilidade no delineamento do método, garantindo o ajuste às exigências da realidade pesquisada. 0 próprio processo foi demarcando e clareando a relação entre método e referencial teórico.

Modificações e rearranjos do planejamento são prioritários nas pesquisas que se inserem no contexto, tornando-se parte dele, sofrendo com ele as intempéries contingenciais. 0 caráter processual da investigação, resultante da colaboração permanente entre pesquisador e professores parceiros, requer o contínuo planejamento da ação ulterior, concebido da reflexão sobre a ação prévia, ciclicamente.

Sob essa ótica, redimensionar os procedimentos para focos não previstos é 
imprescindível à continuidade da proposta. Esta não é uma tarefa simples. Muitas vezes, as alterações podem ser percebidas como conflitivas ou desestabilizadoras aos envolvidos. A análise das informações - para novas decisões - demanda uma atenção especial ao familiar e trivial, que naturaliza toda uma série de pré-concepções, conflitos, ansiedades e incertezas ${ }^{34}$.

Uma dificuldade suplementar à implementação da proposta inovadora é o reconhecimento do limiar entre sua flexibilidade e desmantelamento. Reivindicações legítimas não podem ser confundidas com resistências e controles que engessam as práticas educativas da instituição escolar. A reconfiguração do projeto deve ser orientada pelo processo apropriativo das práticas inovadoras pretendidas.

Quanto à formação docente, cuja ênfase está na construção coletiva do desenvolvimento profissional, nossa inserção no contexto pesquisado respaldou-se na ampla interação entre investigador e sujeitos implicados durante todo o processo, numa espiral permanente de reflexão e ação para equacionar os problemas vivenciados (Schön, 1992; Thiollent, 1994; Pimenta, 2000).

O percurso formativo de desenvolvimento profissional foi delineado pelo isomorfismo (homologia dos processos ${ }^{35}$ ) entre formação e atuação docente, ou seja, formação ludoeducativa para a prática lúdica de ensino, em que o jogo referencia a caracterização das estratégias formativas para ser projetado como respaldo da atuação pedagógica. Assim, 0 pressuposto básico do projeto é imprimir à formação os mesmos parâmetros pretendidos como referencial do cotidiano de sala de aula, sustentando uma metodologia capaz de redundar no isomorfismo entre a formação recebida e a atuação futura do professor (André, 1995; Scarpa, 1998).

$\mathrm{Na}$ perspectiva da homologia dos processos não se igualam os processos de aprendizagem e desenvolvimento do docente aos da criança. 0 acento na homologia enfatiza o reconhecimento dos saberes docentes.

Ao propormos que a prática ludo-educativa se constitui e se consolida por meio de uma formação ludo-educativa, objetivamos um isomorfismo intrínseco à própria concepção de formação continuada de professores, pretendendo contribuir para a autonomia reflexiva. Jogando e examinando o jogo educativo conforme seus interesses e necessidades, 0 adulto/educador enfrenta desafios, avalia suas competências, estabelece novas hipóteses de

34 Hutmacher formulou a expressão 'familiaridade que causa cegueira' para se referir ao funcionamento naturalizado que nos desafia a atingir consciência reflexiva acerca do "que acontece naturalmente na escola (...), o que se tornou tão familiar (...) através desse modo prático do sempre foi assim" (1932 apud Pimenta et al., 2001: 10, grifos do autor).

35 Scarpa esclarece que, na homologia dos processos, deve-se cuidar dos aspectos específicos do trabalho com adultos para que não se corra o risco de infantilizar de nenhum modo as professoras (1998: 44). 
ação, observa e solicita a colaboração dos seus pares, alargando suas zonas de desenvolvimento proximal (profissional).

Assim, as estratégias configuraram-se sobre duas bases: a) reuniões (ou encontros) semanais com as nove docentes do Ciclo I e b) atividades ludo-educativas realizadas em sala de aula, nas classes/séries correspondentes.

Tanto nas reuniões como nas atividades com alunos, os procedimentos pretenderam promover a autonomia dos envolvidos. Entre eles destacamos o estímulo à ativa participação, a primazia de questões desafiadoras, o auxílio ajustável, o uso de analogias e modelos, as situações de confecção e prática de jogos, a observação analítica de episódios videogravados das atividades já empreendidas, bem como vídeos sobre o uso da abordagem vygotskiana na escola ${ }^{36}$.

Essa caracterização aproxima-se dos estudos realizados pelo prisma da Aprendizagem Experiencial (Kolb, 1984), cujo intuito é o desenvolvimento profissional, mediante a proposição de situação-problema, discutida pelos profissionais a fim de levantarem hipóteses de solução, concretizá-las e avaliar os resultados, num ciclo de aprendizagem.

Visando facilitar a organização da escola e, ao mesmo tempo, a integração e participação do corpo docente, os encontros semanais foram programados para ocorrerem durante 0 horário da Jornada Especial Integrada (J El), que totaliza duas horas-aula/dia (100 minutos) na carga horária de cada docente.

Assim que foi organizada coletivamente a agenda de reuniões, iniciamos o projeto, contando sempre com, pelo menos, um dos dois coordenadores pedagógicos e definido coletivamente o programa de encontros semanais a fim de se:

$\stackrel{\leftrightarrow}{\rightarrow}$ discutir sobre as bases conceituais da ludo-educação;

$\stackrel{\leftrightarrow}{\rightarrow}$ planificar cenários lúdicos de aprendizagem como parte da rotina de ensinoaprendizagem;

$\stackrel{\leftrightarrow}{\leftrightarrow}$ instaurar um processo reflexivo acerca da prática docente, pelo contato direto e vicário com a ludo-educação.

Esses três tópicos nortearam o trabalho durante toda sua realização, visto que, à medida que nossa relação com o grupo se instaurava e as experiências se concretizavam com a ludo-educação, as informações, os conhecimentos, os questionamentos acerca de cada um desses tópicos e das interfaces entre eles tornavam-se mais claras e propiciavam 0 encaminhamento de novas discussões.

Em relação ao intervalo de duração, duas condições se impuseram para limitá-lo a oito

${ }^{36}$ Documentário sobre funcionamento do ensino na Escola da Vila, em que a vertente vygotskiana é uma das bases da proposta pedagógica da instituição e de uma coletânea de vídeos produzida pela FDE (1994). 
meses (março a outubro de 2002). Uma delas, decorrente dos limites da pesquisa, determinando a inviabilidade de planejar um período maior que um ano para nossa inserção no contexto educativo. Outra, devido ao calendário escolar, dificultando a continuidade do envolvimento das professoras a partir de meados de outubro. ${ }^{37}$

\section{3 - Criatividade como Princípio Metodológico}

Vivenciamos com as professoras uma experiência vicária, contagiosa - como diria Wallon. A racionalidade dos questionamentos, das explicações, dos argumentos, etc teve sua gênese no impacto causado pela emotividade. Numa atmosfera de cumplicidade afetuosa, compartilhamos histórias e memórias, indignamo-nos juntas, tivemos momentos de desabafo e de riso, convergimos e divergimos teórica e metodologicamente. 0 educador é uma pessoa em totalidade e complexidade. Afetividade e cognição são fatores imprescindíveis para efetivar a formação de professores.

A formação lúdica está condicionada à adequação e qualidade de fatores cognitivos e afetivos, tais como: condições de execução do trabalho, qualificação profissional envolvimento dos participantes, seleção de conhecimentos fundamentais na configuração da proposta, estrutura e imbricação das estratégias formativas, etc. Os resultados do projeto dependem desse design que materializa a proposta de pesquisa.

O design diz respeito a um modo de proceder resultante da 'mão trabalhadora', instrumento da vontade e do poder de criação (Bachelard, 1986). Refletir é um ato do pensamento, tem sua gênese na ação objetiva sobre/com o mundo. É tomar do espelho, pensar sobre a própria imagem para lhe conferir sentido. Numa palavra, é (re)significar. Somos impulsionados a refletir por força de uma ação propulsora. O engajamento num processo reflexivo é sempre voluntário e consciente, pois é inconcebível dizer que alguém reflete sobre si e sobre sua prática 'sem querer' ou 'sem perceber'.

A formação de professores visando a um processo reflexivo da prática pedagógica requer criatividade. Criar é dar forma - sintetiza Fayga Ostrower (2001). Criatividade passa a ter uma conotação singularmente importante para engendrar o design do projeto. Poderíamos designá-la como fundamento de um método capaz de estabelecer o ciclo entre ação e reflexão, entre aprender e transformar o conhecimento.

37 No último encontro do grupo formativo (out/2002), foi acordada a continuidade da proposta. Segundo informações obtidas no reencontro com as educadoras, nove meses após o termino da proposta, soubemos que alterações do corpo docente impedem reaver o mesmo grupo, especialmente as professoras que fazem parte do estudo de casos. Por se manter o interesse pela proposta, inclusive entre docentes recém-contratados e não participantes do percurso formativo, a alternativa posta em pauta é a de estabelecer um vínculo mais duradouro entre Escola e Universidade. 
A ação criativa elicia e mantém a reflexão, proporcionando que os educadores, cúmplices no empreendimento formativo, possam "segurar no corpo as experiências sensoriais, afetivas..." (Dias, 2001) ${ }^{38}$, ou seja, transformadoras do seu próprio fazer pedagógico porque transformadoras deles mesmos.

Num ciclo em espiral, a educação lúdica depende da reflexão sobre a própria prática que, por sua vez, prescinde de um ato voluntário e consciente, originário de uma ação imaginária. Na figura abaixo, procuramos representar essas idéias.

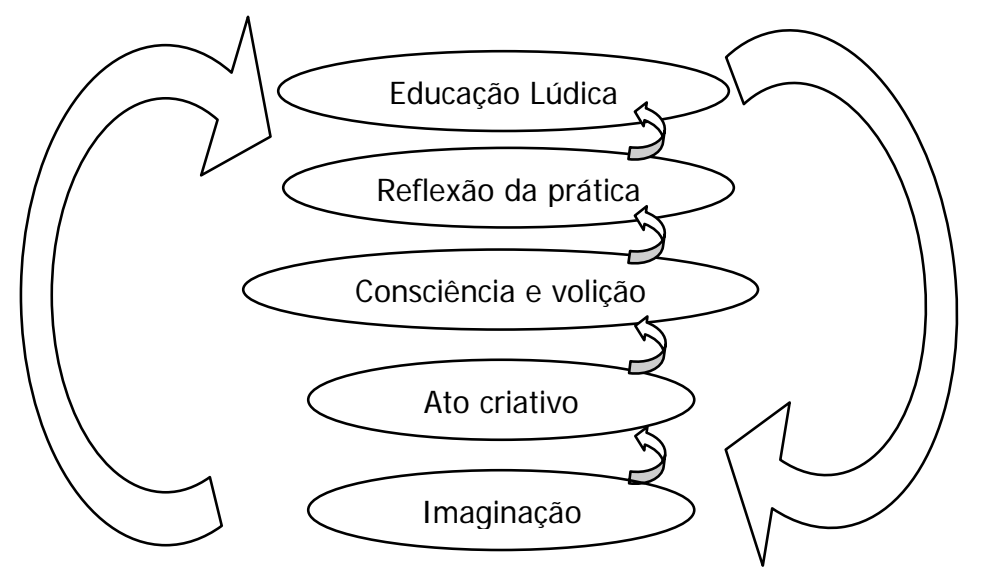

Figura 4.2 - Ciclo de vinculação entre imaginação e educação lúdica

É pela criação que o homem se faz humano. Nela se concentram todas as suas qualidades e potencialidades. Criar é uma necessidade do homem, pertence a sua 'essencialidade'.

Que ação propulsora poderia ser eleita? Qual a sua forma? Como criá-la? É preciso reconhecer que a criatividade se alimenta de experiências, direta ou indiretamente vivenciadas. Tomamos de empréstimo o desenho de um aluno de $1^{\mathrm{a}}$ série, após participar do jogo da História do Teatro ${ }^{39}$. O desenho, que representa Romeu declamando seu amor a Julieta, foi feito depois da leitura de uma recriação desta cena shakespeariana, atuando junto com seus colegas e envolvendo-se com a idéia central da proposta: brincar de 'teatro'. A representação pictórica de cenário e personagens resultou da ação combinatória de um repertório de saberes e habilidades. Mesmo não tendo conhecimento prévio sobre essa obra literária, o garoto aproximou-se dela e recriou-a em seu desenho porque já possuía habilidades para desenhar e porque sabia, de antemão, identificar o significado de uma 'cena

\footnotetext{
${ }^{38}$ Anotações de aulas da disciplina (Programa de Pós-Graduação da FEUSP), O lúdico e as linguagens expressivas na educação da infância: implicações para formação do educador, ministrada pela Profa. Dra. Marina Célia Moraes Dias, no segundo semestre de 2001.

${ }^{39}$ O exemplo reporta-se a uma brincadeira realizada numa das primeiras ocasiões em que alunos, professora e formadora vivenciaram experiências lúdicas.
} 
de amor' para transmitir a idéia do casal enamorado numa criação bidimensional.

De nada adiantaria um vasto repertório se não houvesse imaginação, uma das qualidades do pensamento humano. Imaginar é pensar. Para imaginar são necessárias as funções mais elaboradas de raciocínio, com as quais são selecionadas, combinadas, repartidas, justapostas, organizadas e equilibradas todas as peças que, em síntese, formam a gestalt da obra criada. Da mesma forma como não vemos um traço vertical e outro, sobre ele, horizontal para posteriormente termos o insight de que se trata da letra $T$, a imagem criadora é resultado de um processo complexo de elaboração mental. A imaginação, como sistema funcional, fornece à percepção a capacidade de ser generalizável: mudam-se caligrafias ou tipografias, mas permanecem as qualidades perceptivas da letra, conferindoIhe o conceito de letra $T$.

A imaginação nos permite antever o futuro, planejar nossas ações mediante algo que ainda não existe na realidade. Ela propulsiona 0 ato criativo, tornando-se imaginação material. Uma ação pautada no que existe concretamente, mas que se dá no plano mental para retornar à realidade, transformando o mundo dos objetos e o agente da criação. Cada obra de criação contém em si a história de muitas tentativas e experimentações. Picasso desenhou oito touros diferentes até chegar à forma singularmente cubista desejada (Touro, 1923), ao mesmo tempo diferente e semelhante às anteriores. A imaginação material

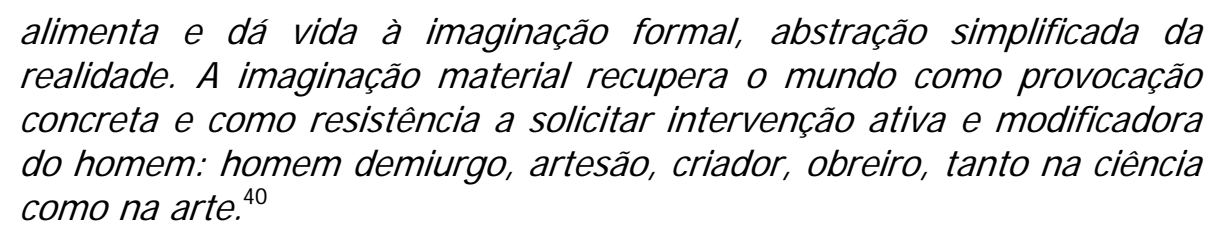

Por isso, é uma falácia 'deixar fluir a imaginação', acreditando tratar-se de uma entidade que emerge espontânea e naturalmente. Associar imaginação à espontaneidade, independente das relações com as experiências pessoais/formativas, é uma concepção largamente difundida; todavia, a imaginação se reporta a funções de pensamento cujo desenvolvimento está intimamente relacionado ao histórico de todo ser humano.

Essa representação restringe o conceito de imaginação, sendo aceita somente nas situações não sérias do cotidiano, na atitude infantil e no campo artístico. Por conseguinte, tal cisão se repercute numa concepção de ensino, geralmente aceita, de que seja presumível haver ocasiões e espaços distintos na promoção de um ou de outro aspecto. 0 primeiro - e mais valorizado - diz respeito aos processos lógicos de raciocínio; o segundo, aos processos criativos que, quando fazem parte da escolarização, são coadjuvantes. De acordo com essa

\footnotetext{
${ }^{40}$ Vide $39^{\mathrm{a}}$ nota de rodapé.
} 
lógica, a aula de matemática não poderia ter qualquer proximidade com a de educação artística; a formação do professor nada teria com criatividade e imaginação.

Para Vygotsky, a falsidade dessa suposição está na dicotomia entre a atividade imaginativa e o mundo real da conduta humana. Sobretudo nos jogos e brincadeiras, o impulso criativo já exerce um importante papel na interpretação e ordenação do real em combinações fantasiosas e originais.

A capacidade de criar não é uma dádiva de uns poucos iluminados, está ao alcance de todos; entretanto, é um processo a ser desenvolvido. Requer tempo, dedicação e estímulo para se tornar meio de apropriação de práticas, instrumentos e símbolos do universo social.

A imaginação adquire uma função de suma importância na conduta e no
desenvolvimento humano, convertendo-se em meio de ampliar a
experiência do homem que, ao ser capaz de imaginar o que não viu, ao
poder conceber baseando-se em relatos e descrições o que não
experimentou pessoal e diretamente, não está encerrado no estreito
círculo de sua própria experiência, (...) pode ampliar muito seus limites
assimilando, com ajuda da imaginação, experiências históricas ou sociais
alheias. Dessa forma, a imaginação constitui uma condição
absolutamente necessária para quase toda função cerebral do ser
humano. (Vygotsky: 1996: 20$)^{41}$

Todo ato que encerra uma combinação nova dos elementos da realidade, por mínima que seja, é um ato criativo. A formação de uma nova palavra, ainda que pela simples sufixação de um substantivo, fundamenta-se nos mesmos princípios psicológicos que engendram a mais bela obra de arte. A produção lingüística é tão vivamente imaginativa quanto a arte. Afirma-se, sem exagero, que a língua inglesa do século XVII deve a Shakespeare um quarto de sua formação morfológica, sem mencionar a riqueza de algumas de suas definições, historicamente conhecidas. Antes dele, inexistia uma palavra como 'bolha' (bubble) ou imagens conceituais incutidas em célebres frases sobre a existência humana: "ser ou não ser, eis a questão" e "uma história contada por um tolo, cheia de ruído e fúria, e sem nenhum sentido" (Shakespeare, 1996: 16).

Por não reconhecer as qualidades formativas da imaginação, e para 'não perder tempo' desenvolvendo-as, a escola se atém à propedêutica transmissão de conhecimentos. Perde muito mais que 'tempo' ao ignorá-las; no melhor dos casos, transforma seus alunos em consumidores de saberes desgastados.

A (re)criação tem direta relação com a riqueza e a variedade da experiência acumulada pelo homem, porque "esta experiência é o material com o qual se erigem os edifícios da fantasia. Quanto mais rica seja a experiência humana, tanto maior será o material de que

\footnotetext{
${ }^{41}$ Nesse item do capítulo, todas as citações de Vygotsky são traduções livres da obra La imaginación y el arte en la infancia (1996), publicada pela Akal, editora madrilena.
} 
dispõe sua imaginação" (Vygotsky, 1996: 17).

No intuito de contribuirmos para a criatividade das professoras, a maioria das estratégias formativas procurou ensejar o ato criativo. Ao experienciar o planejamento e a confecção de objetos lúdicos, o grupo se viu às voltas com circunstâncias ao mesmo tempo divertidas e embaraçosas, como o preparo de um fantoche com meia, cartolinas e sucatas de pequeno porte, a construção de dados de jogo de tabuleiro ou quando, à frente da turma, a professora vestiu uma longa túnica azul para se transformar em Senhora do Tempo, personagem fictícia do jogo de História do Teatro. I somorficamente, os alunos desenharam, criaram regras novas de jogos, elaboraram desafios de jogos de tabuleiro, cortaram garrafas e as transformaram em peças de jogo de boliche.

\section{4 - I nstrumentos de Coleta de Dados}

\subsection{1 - Entrevistas (inicial, final e de feedback)}

Realizamos entrevistas com as professoras em três momentos distintos: logo no início, ao final do projeto e depois de nove meses do término da formação.

Pelas entrevistas iniciais obtivemos as primeiras informações sobre todo o corpo docente do Ciclo I. Além de dados de identificação, elas tiveram o objetivo de: a) apontar os procedimentos de planejamento e exercício da prática docente e b) coletar representações quanto à própria profissionalidade e ao contexto escolar no qual atua.

Ao final do projeto, as entrevistas com as quatro professoras que participaram integralmente do mesmo visaram elucidar a relação entre discurso e prática relativos ao jogo educativo, considerando os efeitos subjacentes ao processo formativo. A diretriz deste conjunto de entrevistas foi comparar modos de pensar e de agir, no que diz respeito ao uso do jogo como mediador do processo de ensino-aprendizagem.

As entrevistas de feedback ${ }^{42}$ tiveram o intuito de extrair informações sobre as mudanças que advieram da experiência realizada. Apenas duas docentes selecionadas participaram das mesmas, por terem sido realizadas numa época em que o estudo de casos já estava definido. Nesse momento - de posse de um registro sistematizado do projeto apresentamos às professoras e aos coordenadores nossas primeiras impressões analíticas a fim de obtermos uma avaliação do material para eventuais correções e complemento de informações, visando tornar nossas interpretações o mais fidedignas possível da realidade vivenciada. Pretendemos também que o reencontro se constituísse numa nova ocasião para

42 Essas entrevistas tiveram duração média de uma hora e meia. Também entrevistamos uma terceira professora (Ida, efetiva, da $3^{\mathrm{a}}$ série), por ter se oferecido espontaneamente. Adicionalmente, o material foi entregue à coordenadora e lido para as demais professoras. Todos os retornos foram incluídos ao conjunto de dados. 
instaurar um clima favorável à reflexão das envolvidas.

\subsection{2 - Jogo do Percurso ${ }^{43}$}

Realizado na oitava reunião do projeto, constituiu-se numa vivência lúdica de confecção e de uso do jogo com a finalidade de avaliar conhecimentos da relação entre jogo, desenvolvimento e aprendizagem escolar.

Com uma estrutura geral elaborada por nós, as docentes foram desafiadas a selecionar, de pequenos textos, fundamentos teóricos da ludo-educação e transformá-los em questões escritas nas cartelas do jogo. Dessa forma, abordaram seu próprio conhecimento e concepções em relação ao jogo, bem como discutiram sua inserção no processo educacional.

\subsection{3 - Registro do Processo em Vídeo}

A tecnologia de videogravação é adequada para investigar fenômenos em que o movimento é parte integrante. A prática pedagógica é, por excelência, um fenômeno vivo carregado de um dinamismo cuja complexidade sofre interferência de múltiplas variáveis. A videogravação possibilita o registro de acontecimentos fugazes e não-repetíveis, que provavelmente escapariam à observação direta. Outra particularidade é que a observação direta, muitas vezes, é dificultada pela carga emotiva que acompanha a situação. A apresentação do vídeo facilita o distanciamento emotivo necessário à análise reflexiva. Como afirma Ferrés (1985), embora a realidade do vivido seja mais importante do que a imagem, o uso da videogravação na formação e na análise desta constitui ferramenta auxiliar na reflexão sobre a prática vivenciada.

O pesquisador se mantém compromissado com vivências, conhecimentos, pressupostos teóricos e hipóteses no ato de transcrever o material. Admitimos, assim, a possibilidade de que diferentes olhares notem diferentes aspectos no material videogravado, o que se manifesta na forma como produzem as transcrições. Como dizem Smolka e Góes (1993 apud Pereira, 1998: 82),

o uso do vídeo não resolve os dilemas epistemológicos fundamentais, constituindo-se apenas em um recurso técnico, cujo modo de utilização independe dos procedimentos de recorte e análise de dados, os quais estão direta e intimamente ligados à postura teórico-epistemológica assumida pelo pesquisador.

Conforme Hardy, Royon et Bréauté (1996 apud Pereira, 1998), assistir às videogravações contribui para a discussão reflexiva, numa 'auto-avaliação reguladora', posta em ação no reencontro distanciado com os modos de operar na prática e reconstruí-los.

\footnotetext{
${ }^{43}$ Vide anexo.
} 
A videogravação revela-se um dos recursos mais privilegiados por pesquisas qualitativas. Em nosso caso, assumiu adicionalmente um papel determinante: proporcionar a atuação no grupo ou junto às professoras durante as atividades em sala de aula.

Com a prévia permissão dos envolvidos, todo o processo formativo foi filmado a fim de:

$\leftrightarrow$ propiciar o uso de situações ocorridas com o próprio grupo, como material de retroalimentação nas reuniões de avaliação do projeto, e

$\stackrel{\leftrightarrow}{\rightarrow}$ constituir fonte principal de material de investigação da trajetória formativa.

Ao final do primeiro semestre e término do projeto, dedicamos reuniões para a avaliação da proposta de formação. A reflexão baseou-se em trechos dos vídeos previamente selecionados e, com o auxílio de um esquema elaborado por nós, as professoras foram convidadas a se engajar na investigação sobre a prática ludo-educativa. A importância desse gênero de estratégia formativa respalda-se na concepção de formação de professores reflexivos, em que o pesquisador compartilha com os envolvidos a análise da proposta e, numa perspectiva colaborativo-investigativa, amplia a atuação autônoma dos professores que investigam sua própria prática.

\subsection{4 - Diário de Campo (registros cursivos da pesquisadora e auxiliares de pesquisa ${ }^{44}$ )}

Segundo Pérez Gómez (1998: 109), o diário de campo é útil para registrar, sem excessiva preocupação com estrutura, ordem e esquematização sistemática, "a corrente de acontecimentos e impressões que o investigador observa, vive, recebe e experimenta durante sua estada no campo".

Em geral, os diários de campo contêm notas escritas ou apontamentos do pesquisador relativos às próprias reflexões quanto ao que ouve, vê e experiencia no decurso do trabalho investigativo. Em nosso caso, tornou-se subsidiário do material videogravado, destacando eventos, apurando nosso olhar para que, na continuidade do processo, os registros fossem retomados e ressignificados, especialmente nas reuniões com o grupo, para enfocar um determinado tema ou levantar questionamento acerca da condução da proposta lúdica.

\section{5 - Procedimentos de Análise para o Estudo de Casos}

É ampla a valorização do estudo de caso em pesquisas na área da Educação, quando a questão de base é considerar significante o contexto cultural no qual se inscrevem a escola e as intervenções educativas propostas (Lüdke \& André, 1986; Stake, 1998).

\footnotetext{
${ }^{44} \mathrm{O}$ projeto contou com três auxiliares de pesquisa: Julie Emy Onishi, Mariana Peres Stucchi e Tânia Amares
} Bueno; à época, todas graduandas do terceiro ano de Psicologia da USP. 
Em nossa investigação, o estudo de caso - fundamentado no ideário da pesquisa qualitativa - mostra-se ainda mais profícuo para proceder às análises. Relaciona-se diretamente com a estrutura do processo formativo, erigido ele mesmo como um caso particular, a partir de um grupo de professores do Ensino Fundamental pertencente a um contexto escolar específico.

Segundo Stake (1998), um caso é um sistema integrado. Pode-se estudar a biografia profissional de um professor, de um aluno, de um programa de ensino ou de um projeto de formação docente.

O caso pode ter gênese intrínseca ou instrumental. Diferentemente do estudo - que se origina por interesse intrínseco do pesquisador - o desta investigação é do tipo instrumental, relativo a uma questão ou necessidade que urge ser compreendida. 0 estudo não se reporta ao caso em si, tem finalidade de compreender outra coisa. Escolhe-se quem, onde e como o caso será delineado. Nessa vertente, é uma ferramenta para obtenção de um quadro mais completo e compreensivo quanto a um assunto. Para nós, revela de que modo a formação ludo-educativa amplia e aprofunda o desenvolvimento profissional das professoras.

Pode-se optar também pelo estudo coletivo de casos quando há possibilidade de coordenar os diferentes casos para a análise de um tema. Sem ignorar o fato de que todo caso é único, ao serem investigados os casos de mais de um professor, de algumas escolas, de um conjunto de classes de uma escola, etc., torna-se viável efetuar comparações, complementaridades, similitudes e distinções para ampliar a compreensão.

Deve-se levar em conta que o objetivo primordial dessa metodologia é a compreensão mais precisa de um sistema em particular. Portanto, toda generalização é apenas indicativa, sugerida. Melhor seria dizer que do material analisado levantam-se hipóteses quanto a um ou outro aspecto que, por sua densidade e representatividade, é passível de generalização. Desse modo, o caso ou os casos implicariam a necessidade de investigações para obtenção de generalizações, por exemplo, por meio de estudos comparativos.

É nessa linha que se emolduram as generalizações naturalistas (Stake, 1998), que decorrem das correlações do leitor com seu repertório de conhecimentos e experiências, enfocando os mesmos questionamentos centrais.

Nossa decisão pelo estudo de casos decorreu de dois fatores. Além do volume de material coletado a partir das reuniões, entrevistas e atividades com os alunos, identificamos diferenças substanciais no modo como cada professora se envolveu com a proposta, fosse pela discrepância com sua prática docente rotineira, fosse por condições institucionais que impuseram sua participação.

Do percurso de aprendizagem experiencial resultou um extenso material: quarenta e seis 
videogravações (quarenta e sete horas), além de gravações em áudio das dezesseis entrevistas (onze horas e trinta minutos). Objetivando recuperar o percurso das duas professoras, enfocamos as seis entrevistas, o conjunto de vinte encontros formativos, além das videogravações de atividades realizadas com suas classes respectivas (cinco com os alunos de Lia e quatro com os de Bel $)^{45}$, não sendo analisado o material envolvendo as classes das demais professoras do grupo.

\subsection{1 - Da Pesquisa de Campo ao Estudo de Dois Casos}

Findo o projeto formativo, dedicamo-nos à transcrição do material. Seguimos a ordem cronológica do processo, independentemente de se tratar de reunião com as docentes ou de atividade ludo-educativa em sala de aula. Desse modo, pudemos apreender a dinâmica do trabalho executado e tomar nota dos aspectos mais relevantes. Nessa fase, recorremos aos registros cursivos para completar as observações. As transcrições se referem não apenas aos diálogos, pois para nossa análise é igualmente necessário considerar outras linguagens, como as gestuais e as expressivas do comportamento de professoras, formadora e alunos. Em seguida, transcrevemos as seis entrevistas realizadas com as professoras, cujo percurso formativo é objeto central da análise.

Do tratamento metodológico com os dados resultaram as primeiras descrições do projeto. O fato de contar com as videogravações facilitou extremamente a apreensão do processo em curso, tornando visíveis os aspectos mais importantes para traçar uma estrutura organizativa do projeto inteiro.

Das múltiplas revisões de vídeos e transcrições, notamos, na seqüência cronológica do projeto, situações que demarcavam mudanças importantes no modo de atuação das professoras nos encontros e no processo de caracterização das estratégias formativas.

Dessa percepção, passamos a registrar os acontecimentos mais significativos em função de nosso objetivo de estudo. Todo e qualquer sinal de que mudanças da prática docente estivessem ocorrendo foram assinalados ${ }^{46}$.

Após a transcrição e organização do material coletado, dedicamo-nos a definir o procedimento mais apropriado para proceder à análise. Inicialmente, pretendíamos nos referenciar à coleção completa de dados. À primeira vista, selecionar uma amostra do trabalho realizado parecia-nos fragmentário. Assim, realizamos algumas análises, considerando a totalidade de material produzido.

\footnotetext{
45 Seis horas em áudio (entrevistas) e trinta e duas horas referentes às videogravações.

46 Para arquivar esses registros, recorremos ao Aplicativo Access, programa do Microsoft 2000 destinado à catalogação bibliográfica, discográfica, fotográfica, etc.
} 
Visando garantir a profundidade e a validade dos resultados, efetuamos a triangulação a partir de três fontes de coleta de dados: videogravações de reuniões do grupo formativo e de atividade ludo-educativa em sala de aula, além dos registros de diário de campo e das entrevistas.

O grande volume de material, porém, tornou inócuas as tentativas de alcançar a profundidade necessária a fim de avaliarmos o projeto na sua totalidade em termos de promoção de desenvolvimento profissional, tornando necessário enveredarmos para a seleção do percurso formativo de duas das professoras, estabelecendo o eixo essencial da análise: o estudo de casos de professoras que, pelas primeiras impressões sobre o material, demonstraram contrastes no percurso formativo.

A partir dessa decisão, empregamos a análise de conteúdo como metodologia para deslindar o processo de desenvolvimento profissional dessas professoras, ou seja, apropriação de saberes ludo-educativos tanto no nível discursivo como no da atuação perspectiva que, ao se pautar em registros audiovisuais, define-se como análise microgenética.

\subsection{2 - Definição das Categorias de Análise}

Pesquisas realizadas desde o início da década de 90, pelo Grupo de Pesquisa sobre Pensamento e Linguagem, da Faculdade de Educação da UNICAMP, utilizam materiais videogravados de análise microgenética, referenciada na corrente histórico-cultural de pensamento. Nessa metodologia, a seleção de episódios propicia o exame de indícios interpretativos, seguindo as proposições vygotskianas de enredar a análise minuciosa de um processo a fim de captar as transformações em curso. De acordo com esse referencial, os episódios são caracterizados em função dos objetivos do estudo, servindo para dirigir a atenção ao funcionamento enunciativo-discursivo e aos detalhes das ações intersubjetivas (Góes, 2000), incluindo falas, gestos, posturas e atuação entre os sujeitos.

Nessa 'lente de aumento' sobre os episódios, em que se torna possível ir e vir nas imagens, congelar, retornar várias vezes, são objeto de atenção o nível dos discursos e o nível das ações, considerando tanto os dados internamente convergentes como os divergentes.

A análise microgenética filia-se à análise de conteúdo - pela qual o pesquisador elabora inferências que se originam de operações lógicas sobre um conjunto de proposições, mediante análises e sínteses dos dados de pesquisa (Bardin, 1977).

Krippendorff (1980 apud Lüdke \& André, 1986: 41) acrescenta que, ao transmitirem experiência vicária, as inferências não se baseiam unicamente no conhecimento lógico- 
formal, mas também no conhecimento experiencial do pesquisador. 0 tratamento das mensagens para a elaboração de inferências envolve também sensações, impressões, percepções e intuições. Para o autor, "o reconhecimento desse caráter subjetivo da análise é fundamental para que possam ser tomadas medidas específicas e ser utilizados procedimentos adequados ao seu controle".

De acordo com Bardin, as inferências resultam na admissão de uma proposição devido a sua ligação com as proposições anteriormente construídas e aceitas como verdadeiras. Ou seja, a inferência é uma interpretação do pesquisador, formulada a partir dos pressupostos que norteiam seu estudo.

A inferência pode partir de informações que retratam o conteúdo da mensagem ou mensagens, o que normalmente ocorre. Há possibilidade também de surgir de premissas consideradas, elas mesmas, o núcleo central dos resultados do estudo. Em ambos os casos, a informação é decorrente da apreciação objetiva da mensagem.

Para Bardin, não há uma única forma ou ponto de vista para abordar as mensagens, o que não deve ser entendido como falta de critérios ou como visão subjetiva do estudo. A objetividade na análise dos conteúdos subjacentes às mensagens não ignora a subjetividade do investigador, tampouco as múltiplas possibilidades em função dos objetivos do estudo. Assim, tem-se, na metodologia de análise de conteúdo, a definição das unidades de análise.

A unidade de análise pode ser o texto inteiro, partes dele, parágrafos, sentenças, frases ou palavras. Os procedimentos também são variáveis. É possível verificar a freqüência em que cada unidade de análise está presente, estudar a estrutura lógica, o encadeamento das unidades de análise ou definir temáticas representadas pelo conjunto de unidades de análise. A combinação dessas alternativas também é viável. A opção depende da natureza da pesquisa, do que ela exige, a que fins se destina, das questões específicas e do referencial teórico.

Apoiadas em Holsti (1969), Lüdke e André (1986) consideram que a unidade de análise pode ser combinada com duas outras unidades: a de registro e a de contexto. No primeiro caso, segmentos específicos do conteúdo são selecionados. Desse modo, a análise corresponde à freqüência com que, por exemplo, determinada expressão, personagem ou tema aparece. No caso da unidade de contexto, é mais importante analisar em que circunstâncias uma unidade ocorre, para além da freqüência.

No caso de grande volume de dados, a quantificação pode ser um procedimento recomendável pelo qual se produza, posteriormente, a interpretação analítica, porém não exime o pesquisador das leituras e releituras do material tanto para organizar os dados em função das unidades de análise quanto para determinar os temas centrais resultantes delas. 
A definição de temas é opcional, novamente dependente dos propósitos da investigação. Entretanto, é habitualmente utilizada, constituindo-se num processo indutivo que culmina na delimitação das categorias essenciais do estudo.

A construção de categorias não é tarefa fácil. Elas brotam, num primeiro momento, do arcabouço teórico em que se apóia a pesquisa. Esse conjunto inicial de categorias, no entanto, vai ser modificado ao longo do estudo, num processo dinâmico de confronto constante entre teoria e empiria, o que origina novas concepções e, conseqüentemente, novos focos de interesse. (Lüdke \& André, 1986: 42)

As unidades de análise originam as categorias. É pela recorrência, regularidade, aparecimento em contextos variados das unidades de análise que se formulam agrupamentos de informação, dos quais as categorias são estabelecidas. É preciso atentar para as informações discrepantes e isoladas, que podem se constituir em elementos fundamentais na elucidação das questões do estudo. Se, por meio das revisões das categorias, não puderem efetivamente fazer partes dos demais agrupamentos, devem ser classificadas num grupo à parte para, depois, integrar a totalidade do exame interpretativo.

Obtido o conjunto de categorias, num processo denominado 'convergente', o próximo passo envolve o inverso, o 'divergente', em que o sistema de categorias é enriquecido mediante três operações: aprofundamento, ligação e ampliação. Do novo exame do material, o pesquisador visa estabelecer elos de ligação entre os itens de cada conjunto e entre cada conjunto de categorias, combinando-os, separando-os e reorganizando-os a fim de sobressair aquilo que seja realmente relevante e significativo para a investigação.

Em nosso estudo, consideramos unidade de análise tudo o que pode ser entendido como ação ou operação mental, observável nas discussões dos encontros formativos, nas entrevistas e na prática ludo-educativa das professoras junto a seus alunos. Estabelecemos que essas unidades devem ter vínculo com os seguintes assuntos (complementares e não excludentes):

$\stackrel{\leftrightarrow}{\rightarrow}$ aspectos procedimentais, estratégicos e conceituais do jogo educativo;

$\Leftrightarrow$ posicionamento profissional em relação ao corpo discente;

$\stackrel{\leftrightarrow}{\leftrightarrow}$ posicionamento profissional em relação à prática pedagógica.

As unidades de registro constituíram-se de "uma informação, uma declaração, um juízo (ou uma interrogação ou negação), em suma, uma frase ou um elemento de frase que, tal como a proposição lógica, estabelece uma relação entre dois ou mais termos (Silva, 2000:185). As unidades de registro (cenas, frases) foram determinadas pela seguinte questão: de que trata a situação e/ou o enunciado? Com base nas respostas obtidas, 
definimos o elenco de temas que se tornaram eixo de toda a análise. ${ }^{47}$

Nas transcrições, enquanto as unidades de registro foram sublinhadas pelo uso de cores distintas, marcações à margem do texto destacaram as unidades de análise.

Como unidade de contexto consideramos o protocolo de transcrição de cada encontro, entrevista ou atividade com os alunos, com a finalidade de nos remeter à situação onde se inserem as unidades de análise (futuras categorias) e as unidades de registro (elementos temáticos do discurso).

o processo de categorização implicou o agrupamento e o reagrupamento do material. Dos recortes das unidades de análise, obtivemos um conjunto de pré-categorias. 0 mesmo foi feito com as unidades de registro para formulamos um agrupamento provisório de temas centrais do estudo.

A revisão das pré-categorias, pretendendo julgar sua adequação e processar as alterações necessárias, demandou a leitura vertical e horizontal dos materiais transcritos, codificados e categorizados. Dessa revisão e mediante o esforço minucioso de lhes garantir homogeneidade interna, heterogeneidade externa, inclusividade, coerência e plausibilidade, originaram-se as categorias propriamente ditas. Simultaneamente, os temas foram exaustivamente revistos a fim de chegarmos a um grupo definitivo de temas nucleares.

Analisadas as três coletâneas de materiais (entrevistas, encontros do grupo, situações lúdicas com os alunos), realizada a extração dos temas e erigidas as categorias, empreendemos uma leitura descritiva e interpretativa do material. Esse momento do processo estabeleceu a inter-relação de cada categoria ao conjunto de temas, de forma sistemática, explicitando as correlações do aporte teórico com os dados colhidos.

Neste estudo, além de auspiciarmos observar que as professoras passaram a reconhecer a relevância da atividade lúdica nos processos de aprendizagem e de desenvolvimento dos educandos, pretendemos analisar as contribuições do projeto formativo para darmos início a:

$\leftrightarrow$ análise reflexiva das professoras quanto a sua própria atuação profissional;

$\stackrel{\leftrightarrow}{\rightarrow}$ desenvolvimento de competências docentes em relação à educação lúdica;

$\stackrel{\leftrightarrow}{\rightarrow}$ construção de um sistema de saberes sobre a ludo-educação.

Para atender a esses objetivos, a elaboração de temas e categorias de análise demandou dois processos interdependentes. 0 primeiro, diacrônico, dirigiu-se ao percurso formativo.

\footnotetext{
47 A noção de 'frase' não se restringe ao sentido gramatical, ou seja, como elemento representante de fala, comportamento ou evento. Exemplarmente, a unidade de registro pode se referir a comportamento: "a professora caminha entre as carteiras dos alunos, observando". Também pode referir-se a evento, como ocorre em: "no momento em que precisam colar a 'boca' do fantoche na meia, as professoras se ajudam mutuamente". Nesse último caso, o evento (colar a boca) define o subseqüente comportamento generalizado. Portanto, uma unidade de análise pode ser expressa por diversas unidades de registro e, da mesma forma, um registro pode conter mais de uma unidade de análise, sendo sublinhados e destacados todos os casos.
} 
Por conseguinte, no de estudo de casos visamos cotejar os dados com o arcabouço teórico sobre desenvolvimento profissional, abordando especialmente a reflexão da prática pedagógica.

No diagrama abaixo, reproduzimos esquematicamente todo o processo de categorização e construção dos temas, indicando os termos que serão utilizados na descrição da metodologia empregada nesta investigação.

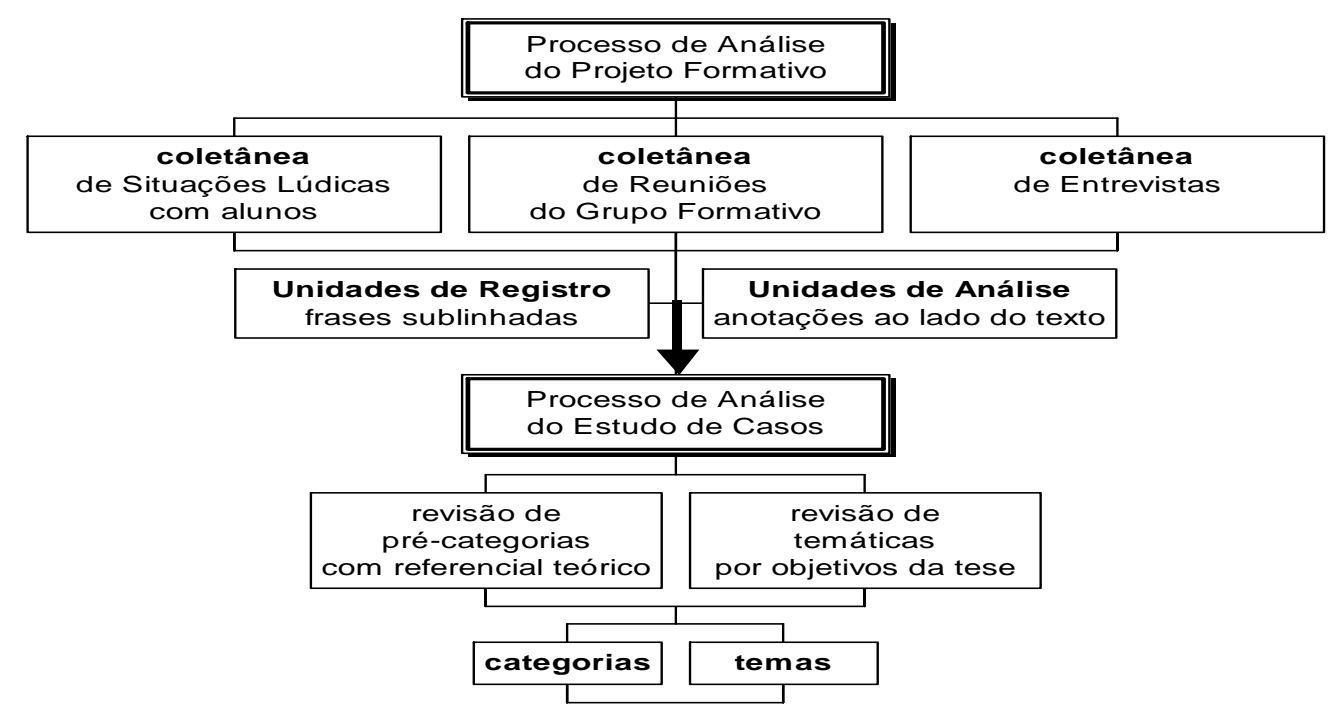

Figura 4.3 - Diagrama Descritivo da Análise do Projeto Formativo e do Estudo de Casos

\subsubsection{1 - O processo de análise do percurso formativo}

A partir de uma descrição global da proposta, a primeira decisão para formularmos as fases de desenvolvimento foi a separação do material em três coletâneas (arquivos de dados):

a) transcrição dos encontros do grupo formativo;

b) transcrição das situações de observação e de realização de atividades lúdicas em sala de aula;

c) transcrição de entrevistas iniciais, finais e de feedback.

Cada coletânea foi analisada separadamente. Procedemos do mesmo modo com outros registros: diário de campo da pesquisadora/formadora; material escrito pelas auxiliares de pesquisa e das professoras (ocasionais - em função de desempenharem um papel específico no encontro formativo - e espontâneos, como os 'bilhetes' entregues à formadora para prestar informações ou solicitar apoio) e, finalmente, registros produzidos pelos alunos (desenhos, textos, folhas de rascunho e outros materiais vinculados à realização das atividades lúdicas em sala de aula). 
No conjunto de dados, assinalamos unidades de registro (frases sublinhadas) e de análise (anotações ao lado do texto). Como resultante, obtivemos uma série de elementos (temáticas provisórias e pré-categorias).

0 próximo passo foi reunir novamente as três coletâneas para formularmos um critério único de identificação das mudanças mais expressivas na atuação das professoras ao longo do projeto, em direção ao propósito da tese.

Objetivando qualificar essas transformações, empregamos a triangulação como estratégia para revisar o material e definir como critério a postura das professoras frente às situações propostas e aos desafios travados no decorrer do projeto, ações verbais e não-verbais indicando que a perspectiva ludo-educativa estaria fazendo sentido a elas, à sua prática e aos saberes da prática.

\subsubsection{2 - O processo de análise do estudo de casos}

A descrição analítica do projeto deflagrou que, embora houvesse o mesmo grau de envolvimento das professoras que participaram integralmente do percurso formativo, tornaram-se perceptíveis diferenças substanciais na forma com que cada uma delas forjou reflexões acerca da atuação profissional e vivenciou a prática lúdica junto aos alunos. Tais diferenças foram se tornando mais palpáveis a cada fase do projeto.

Em que bases estariam assentadas essas diferenças? Estariam relacionadas a processos reflexivos promovidos pela experiência formativa? Em que medida o projeto teria propiciado desencadeá-las? De que modo estariam repercutindo no desenvolvimento profissional das professoras?

Consideramos que, em parte, refletiam componentes da profissionalidade, alusivos a experiências e saberes da prática anteriores ao projeto. Poderiam simbolizar níveis distintos de familiaridade pessoal com atividade lúdica e dimensões diferentes de apropriação do jogo no ensino. De outra parte, evidenciavam distinção no desenvolvimento de um saber-fazer ludo-educativo.

Com 0 intuito de lançar luzes sobre a significação dessas diferenças, definimos o estudo de casos como meio de investigar os fatores específicos do processo formativo relacionados ao desenvolvimento profissional de duas das nove professoras participantes, selecionadas conforme os seguintes critérios:

$\Leftrightarrow$ terem participado integralmente dos encontros formativos (de março a outubro/2002);

$\Leftrightarrow$ terem experienciado, com seus alunos, estratégias ludo-educativas mediadoras do processo de ensino-aprendizagem; 
$\stackrel{\leftrightarrow}{\leftrightarrow}$ haver equiparação de envolvimento ${ }^{48} \mathrm{com}$ a proposta ludo-educativa de formação;

$\leftrightarrow$ haver contrastes entre as professoras quanto à mudança na prática docente, em direção à educação lúdica.

\section{a) Coletânea dos encontros do grupo formativo}

Com relação às reuniões do grupo, averiguamos que assuntos foram mais debatidos e suas respectivas repercussões nas reflexões subseqüentes. Focalizamos as problemáticas trazidas e os encaminhamentos apresentados.

Pela análise transversal, orientada pelas unidades de registro e de análise assinaladas, procuramos responder as seguintes questões:

$\leftrightarrow$ Quais os temas dos enunciados? Os alunos? Os saberes escolares? A confecção de jogos educativos? Conhecimentos sobre ludo-educação?

$\stackrel{\leftrightarrow}{\rightarrow}$ Quais os tipos de enunciados: um questionamento, uma explicação, um exemplo, uma discordância, resposta a um problema?

$\leftrightarrow$ Que comportamentos e expressões gestuais, denotando interação, envolvimento ou mesmo distanciamento, recusa, apareceram?

$\leftrightarrow$ Como se configuraram as interações do grupo? Houve colaboração e parcerias? E quando, ou em função de quê, estas puderam ser observadas? Houve confrontos? De que ordem? Como foram percebidos e tratados pelo grupo?

Dentre as unidades de análise, também destacamos estratégias/procedimentos formativos (ação da pesquisadora no/com o grupo), considerando as metas do projeto, as condições institucionais e as especificidades da profissionalidade de cada integrante do grupo formativo.

Averiguamos as possibilidades de agregar as temáticas, requalificá-las e reclassificá-las. Em primeiro lugar, verificamos as duplicidades e proximidades para formar novos reagrupamentos. Depois, destacamos as que se reportam explicitamente ao papel do jogo na atuação pedagógica. Quanto às referências a condições institucionais, experiência profissional pregressa não lúdica, interação grupal e qualificação dos procedimentos/estratégias formativas, mesmo importantes para a compreensão do desenvolvimento profissional, não fizeram parte do conjunto de temas por se distanciarem do escopo desta investigação.

Como resultante dessas reorientações, postulamos um conjunto-síntese de quatro temas

48 Pascal \& Bertram (2000) e Oliveira-Formosinho \& Formosinho (2001) apontam critérios para 'grau de envolvimento', considerando expressões faciais e gestuais, tempo de verbalizações e de participação nas ações práticas, qualificação do discurso e atuação junto aos alunos. 
que, não excludentes, retratam os fatores indispensáveis à aprendizagem sobre prática ludoeducativa de ensino.

Temas:

\section{1 - Jogo: recursos e procedimentos}

Tema referente à confecção do jogo: materiais para confecção, adequação e obtenção de sucatas, objetos lúdicos, procedimentos instrucionais.

\section{2 - Caracterização de jogo educativo}

Registros que se reportam às regras de jogo, considerando o tipo de atividade lúdica e sua vinculação com conteúdos do programa curricular. Designa, no plano pragmático, aspectos inerentes à noção de jogo como atividade composta de situação imaginária e regras. É resultante da articulação das experiências ludo-educativas vivenciadas com as discussões em curso nas reuniões, pela elaboração de hipóteses sobre as contradições implicadas no jogo: funções lúdica e educativa, liberdade e controle, flexibilidade das ações individuais e negociação entre pares.

\section{3 - Jogo: conceituação}

Requer maior abstração e complexidade, envolvendo o vínculo entre caracterização das atividades lúdicas e processo de aprendizagem. Aborda princípios gerais quanto à flexibilização no uso do jogo para contextos e objetivos variados. É resultante de processos psicológicos de generalização e descontextualização endereçados à criação de um sistema conceitual acerca do jogo para o ensino. Não se trata de buscar, nos dados, conceituações plenamente articuladas. Muito mais significativo é averiguar em que medida as professoras refletem sobre o jogo educativo (estabelecendo relações entre idéias), hierarquizam ordenadamente características e engendram discussão acerca de seu próprio saber-fazer (abordando problemas, investigando, hipotetizando soluções). Portanto, diz respeito a mecanismos metacognitivos em formação acerca da abordagem ludo-educativa.

\section{4 - J ogo: atuação discente (aprendizagem e comportamento)}

Destacamos unidades de registro relativas ao corpo discente por enfocarem, não apenas o comportamento dos educandos, mas seu aprendizado e desenvolvimento, e devido sua alta incidência nos registros, mesmo sem referência explícita à prática ludo-educativa.

Categorias:

As categorias, originárias da relação entre unidades de análise e perspectiva kolbiana, 
visam conduzir a discussão do processo reflexivo promovido pelo projeto. Vale salientarmos que cada categoria pode se vincular a mais de um tema.

Baseando-nos nos níveis de profissionalidade elaborados por Kolb, o conjunto de categorias representa modos de agir e refletir sobre a experiência formativa, sinalizando transformações no desenvolvimento.

As categorias reportam-se ao processo dialético de desenvolvimento, determinado pela inter-relação entre complexidade de diferenciação e integração hierárquica. A diferenciação deriva das operações mentais necessárias à apropriação da experiência formativa para 0 desenvolvimento profissional, por exemplo: reunir e selecionar informações; aprimorar procedimentos para conceituar; adicionar, substituir e ordenar os elementos centrais da experiência; flexibilizar seqüências dos componentes da vivência ludo-educativa.

A significação da experiência para a profissionalidade envolve consciência e autonomia, representadas em três níveis qualitativamente diferentes: aquisição, especialização e integração.

A diferença da integração e da diferenciação entre níveis de consciência e de desenvolvimento se traduz nas quatro dimensões de aprendizagem e suas respectivas categorias, conforme apresentado a seguir.

\section{1 - Experiência concreta e complexidade afetiva (via apreensão)}

A afetividade é inerente ao desenvolvimento profissional. Basta nos remetermos à expressão gestual e comportamental das professoras, diante de um problema proposto ou originário da discussão, para vislumbrarmos o envolvimento, a persistência em encontrar soluções, o silêncio irrequieto ou a desistência. A experiência concreta é vicária, apreendida de forma intuitiva. No nível aquisitivo, os sentimentos misturam-se a julgamentos valorativos. No de especialização, surge um sistema - embora egocêntrico - em que sentimentos e valores são diferenciados. Na integração, em busca da coerência com os princípios morais, os valores e sentimentos tornam-se objeto de análise dentro de um sistema relativizado. Nessa apreciação metacognitiva, a consciência sobre sentimentos e valores promove o desejo pelo aperfeiçoamento das próprias qualidades profissionais.

A categoria representativa desta dimensão é exemplificar. Nela, o componente afetivo media as inquietações, as surpresas, as descobertas observadas nos registros. A exemplificação, apesar de se pautar na realidade concreta, é um meio importante para a elaboração futura de idéias gerais e sólidas acerca do uso de objetos lúdicos, regras e caracterização do ensino com o jogo. Ao dizerem "o Percurso é um jogo de tabuleiro"; "nas cartelas do jogo estão os conteúdos (escolares)"; "(o trabalho em) grupo fez os alunos 
ficarem mais colaboradores uns dos outros", "eu tenho que aprender a ser menos dominadora", as professoras denotam apreensão de elementos importantes para a construção de um saber ludo-educativo que faz sentido para sua prática educativa.

\section{2 - Observação reflexiva e complexidade perceptiva (via intenção)}

A complexidade da percepção está diretamente relacionada à intencionalidade de ater-se aos fenômenos, procurando estabelecer relações, ordenações e projeções, o que corresponde a um nível perceptivo mais complexo do que a observação fragmentária, episódica, pontual. A atenção e a observação desvinculadas de significações correspondem ao nível aquisitivo. No de especialização, significados pessoais são agregados à observação, tornando efetiva a reflexão sobre o que se observa e a criação de esquemas alternativos de significação. No nível integrativo, o julgamento prévio sobre o que observar está intimamente relacionado à sua funcionalidade, fomentando 'esquemas relativizados' para significar o observado e escolher perspectivas múltiplas de significação.

Em relação a essa modalidade de aprendizagem, definimos duas categorias que expressam de modo mais fidedigno os dados obtidos: indagar e observar. Indagar compreende dois gêneros de questionamento: via direta (perguntas) e via indireta (hipóteses). Conforme os três níveis de diferenciação, a complexidade das indagações varia desde a que requer resposta única até a que implica discutir o tema, atentando para a opinião dos demais e visando resolver problemas.

Observar pressupõe hipótese; contudo, diferentemente do questionamento, busca a conceituação, mesmo quando impregnada da concretude da experiência observada. Da mesma forma que a indagação, a observação tem graus distintos de complexidade, podendo se fixar num aspecto circunscrito da realidade, restrita e sem correlações, ou encaminhar-se para a generalização conceitual, através da exposição de uma hipótese mais tangível à realidade que, ao mesmo tempo, vislumbre a sistematização de conceitos.

Indagar refere-se explicitamente a solicitar apoio, por exemplo: "Que material devo usar na confecção?"; "Que regras definem o uso deste jogo?"; "Como nós vamos fazer a observação durante o jogo?"; "Se os alunos não sabem fazer os peões, vão confeccionar? Como?".

A observação pressupõe explicitação de uma idéia. Este é o caso dos seguintes exemplos: "Tem que pensar num jeito pro jogo dar conta de trabalhar com quarenta crianças ao mesmo tempo..."; "o jogo faz mudar o modo como os alunos estão acostumados a se sentar em sala de aula, parece que isso acontece sempre..."; "eu concordo que é importante, ... mas eu não saberia fazer o acompanhamento da aprendizagem enquanto 0 
jogo acontece, é muito difícil!".

\section{Conceituação abstrata e complexidade simbólica - via compreensão}

$\mathrm{Na}$ proposição de Kolb, a dialeticidade entre conceituação abstrata e complexidade simbólica estabelece uma espiral em que se modificam os níveis de compreensão. Simbolizar, ou melhor, significar exige integração dos processos de pensamento, propiciando avaliação do que se sabe, do que não se sabe e do que seria necessário para elevar os conceitos a níveis de maior abstração, formulando significações generalizadas e metacognitivas (auto-avaliativas).

A aprendizagem que promove a produção de significados abstratos visa alcançar conceitos de natureza refletida, distanciada e descontextualizada da realidade concreta, permitindo a formação de imagens mentais compreensivas. No nível primário do desenvolvimento, conceituar é um ato fortemente associado a reconhecer e comparar, em que explicações e conhecimentos pré-existentes predominam na formulação de idéias e hipóteses explicativas. No segundo nível, novos saberes passam a figurar lado a lado com os anteriores, sem que se configure um sistema conceitual ordenado e coeso. No último nível, os significados são reunidos num sistema simbólico, integrando princípios gerais que são simultaneamente generalizáveis e descontextualizáveis, viabilizando a antecipação de problemas e de soluções a serem testadas na ação real.

A categoria atribuída a essa dimensão é analisar. Nela, estão incorporados os julgamentos que as professoras fazem sobre um tema, um objeto lúdico, um modo de proceder, etc. Assim, para os fins deste projeto de formação, julgar requer noções conceituais sobre a ludo-educação, mesmo quando tais princípios conceituais não estejam explicitamente definidos. Portanto, analisar designa uma grade de proposições, desde as incipientes - em que faltam elementos para a constituição de sínteses - até as que comportam densidade teórica capaz de ensejar mecanismos metacognitivos, pelos quais a professora investiga sua atuação docente à luz dos princípios gerais da ludo-educação.

Essa categoria é referida a casos como: "(é importante avaliar os cadernos dos alunos), porque lá no caderno tá a íntegra do trabalho do professor, é um retrato do que o professor fez ou deixou de fazer"; "o professor... precisa ter um controle daquilo que faz, é para isso que serve o semanário49"; "os cadernos dos dois (professor e alunos) são úteis até pra hora de sentar juntos (professores) e conversar sobre o que tá dando certo e o que precisa melhorar... porque você tá caminhando de um jeito que... até acha que dá certo, mas não está; e conversando... pode enxergar uma coisa que você não tava vendo".

\footnotetext{
49 'Semanário' é um caderno individual de registros produzidos semanalmente.
} 


\section{4 - Experimentação ativa e complexidade comportamental (via extensão)}

Esse tópico articula categorias e temas num alto grau de complexidade. Kolb denomina de 'experiência ativa' a extensão ou exteriorização do que foi apropriado de experiências anteriores, observadas, analisadas e (re)conceituadas. Possui um teor pragmático, pois revela a funcionalidade da aprendizagem em comportamentos tornados mais complexos. No percurso de desenvolvimento, compreende meios pelos quais a professora retira de sua experiência conceitos, regras e princípios que orientem e antecipem ações em situações novas, bem como a modificação de conceitos para melhoria da eficácia. Pelo confronto entre a prática existente e o surgimento de novas perspectivas são criados mecanismos mais diferenciados e integrados na resolução de problemas, concedendo aos atores envolvidos o crescente poder de os resolver e se conscientizar sobre as competências que implicam.

No nível da aquisição, os comportamentos traduzem respostas diretas às circunstâncias, e as metas pretendidas são de caráter imediato. Na especialização, o desenvolvimento se volta a metas prospectivas, isto é, de longo alcance, que determinam assumir riscos e articular estratégias intercambiáveis. Na integração, hipóteses são testadas e metas são alteradas com base nos resultados obtidos; é aceitável a probabilidade de surgirem situações novas e desconhecidas, que requeiram mudanças no âmbito do saber-fazer, seja pela articulação das estratégias ou reorientação das metas; em outras palavras, a necessidade de refletir e auto-avaliar a atuação profissional torna-se presente.

Nesta modalidade, solucionar (um problema) indica todas as ocasiões em que, no discurso e na atuação em sala de aula, a professora alude a formas de experienciar ativamente a ludo-educação. Exemplarmente, as unidades de registro refletem situações hipotéticas de experimentação de ludo-educação, quando a professora se reporta à resolução de problemas, através da avaliação das experiências passadas (visando a novas vivências, modificadas pela avaliação), para o planejamento de ações futuras (qualquer situação lúdica a ser implementada, prevista ou não pelo projeto).

Solucionar indica desde o nível imediatista - relativo à resolução de um problema durante o planejamento ou à realização de uma atividade lúdica - até as soluções mais sofisticadas, demonstrando apropriações do ideário ludo-educativo de maneira mais integrada e visando à ação de longo prazo.

Exemplares da busca de solução pelas professoras aparecem em: "a minha turma usou tampinhas (de garrafa de refrigerante) para os peões do jogo"; "o tabuleiro poderia representar o percurso de vinda até a sala de aula, começando pela porta de entrada da escola"; "nas cartelas, além do desafio (problema a ser resolvido pelo jogador), pode ter coisas pra ajudar, uma figura ou uma informação, assim dá pra usar em várias situações 
diferentes".

\section{Quadro 4.2 - Temas e categorias dos encontros formativos}

\begin{tabular}{|c|c|}
\hline \multicolumn{2}{|l|}{ Temas } \\
\hline \multicolumn{2}{|c|}{1 Jogo - recursos e procedimentos } \\
\hline \multicolumn{2}{|c|}{2 Caracterização do jogo educativo } \\
\hline \multicolumn{2}{|l|}{3 Jogo - conceituação } \\
\hline \multicolumn{2}{|c|}{4 Atuação discente (aprendizagem e comportamento) } \\
\hline Dimensões da Aprendizagem & Categorias \\
\hline Experiência concreta e complexidade afetiva & 1 Exemplificar \\
\hline \multirow[t]{2}{*}{ Observação reflexiva e complexidade perceptiva } & 2 Indagar \\
\hline & 3 Observar \\
\hline Conceituação abstrata e complexidade simbólica & $4 \quad$ Analisar \\
\hline Experimentação ativa e complexidade comportamental & $5 \quad$ Solucionar \\
\hline
\end{tabular}

\section{b) Coletânea de situações ludo-educativas com os alunos}

Seguindo o mesmo procedimento utilizado nas transcrições dos encontros do grupo, a análise transversal contemplou o material das turmas das professoras Lia e Bel. Foram sublinhados quatro conjuntos temáticos (unidades de registro), tendo a atuação docente como referência.

Temas:

\section{1 - Organização do Cenário de Aprendizagem}

O tema designa sobretudo ações pertencentes ao início da atividade. Refere-se à conformação do espaço físico: como é ocupado e utilizado pelos alunos; disponibilidade de recursos pedagógicos; instruções, pistas, modelos; questões desafiadoras e para averiguar a compreensão da turma sobre a atividade. 0 preparo do cenário de aprendizagem tem o propósito de oferecer aos alunos condições para que estabeleçam relações entre a aprendizagem dos conteúdos escolares e a proposta de jogo, identifiquem-no segundo suas regras, dêem os primeiros passos na preparação do material lúdico e se agrupem de modo a tornar exeqüível a atividade.

\section{2 - Interação Social: co-participação decisória dos alunos}

Esse tema se reporta à ação docente que contribui para ensejar a autonomia discente. Em situação ludo-educativa, significa apropriar-se das características inerentes ao jogo facilitadoras do comportamento autônomo - para exacerbá-las, a fim de que a ação lúdica 
promova refinamento da metacognição dos alunos. De um lado, a interação professora/aluno(s) expressa gradações de ação docente que favoreçam a ativa participação dos alunos nas decisões a serem tomadas sobre o jogo, antes, durante e após sua execução. De outro, a observação da interação criança/criança fornece elementos complementares para avaliar sua desenvoltura na criação de alternativas, modificação de regras e solução de problemas propostos pela atividade. Desse modo, todo o clima interativo é considerado na captura dos movimentos de delegação e imposição, apreciação e correção, apoio e recriminação, negociação e direcionamento.

\section{3 - Mediação pedagógica: atuação da professora para aprendizagem de conceitos escolares}

Mesmo que interação e mediação sejam conceitos tão imbricados, causando estranhamento vê-los separados, optamos por essa via para colocar em evidência as mediações com acentuado valor pedagógico, voltadas explicitamente à relação entre jogo e conteúdos escolares. Diferentemente das interações que estabelecem zonas de negociação entre professora e alunos, demarcadas pelo desempenho autônomo do corpo discente, as mediações pedagógicas se referem especialmente à atuação da professora na definição de conceitos, descrição de um objeto do conhecimento, explicações e questionamentos que faz aos alunos, sobretudo durante a atividade. A ocorrência dessas mediações pedagógicas não é exclusiva do momento de realização do jogo, mas pode se pronunciar também na organização do cenário ou após a atividade.

\section{4 - Aprendizagem e desenvolvimento: avaliação e registro da aprendizagem}

O foco na atuação docente não pode negligenciar as metas de aprendizagem e desenvolvimento do educando. Nesse sentido, o tema visa qualificar três situações. A primeira ocorre durante o jogo, em que aprendizagens em processo são capturadas mediante a ação dos alunos ${ }^{50}$ ou pela intervenção docente. A segunda, mais freqüente que a anterior, ocorre na fase de 'análise do jogo' (Wassermann, 1990). Em ambos os casos, o tema comporta incentivo e suporte para que o aluno observe e descreva a experiência ludoeducativa; reconheça, compreenda e formule hipóteses acerca dos saberes escolares implicados na atividade; seja provocado por novas inquietações; identifique estados afetivos eliciados pela ação lúdica; estabeleça novos vínculos entre jogo e aprendizagem, entre outros. A terceira diz respeito diretamente à sistematização das aprendizagens, através do

$50 \mathrm{O}$ fato de as filmagens focarem a atuação da professora limita sobremaneira o número de episódios relativos ao corpo discente. Na sua maioria, decorrem da aproximação/interação da professora com um grupo de alunos. 
registro realizado pelos alunos: textos, tabelas, gráficos, desenhos, esquemas, etc.

\section{Categorias:}

Dada a diferença entre cenários - encontros do grupo formativo e realização de atividade ludo-educativa em sala de aula - as quatro dimensões kolbianas de aprendizagem embasam uma categorização distinta da construída sobre as reuniões:

\section{1 - Explicar (Experiência Concreta e Complexidade Afetiva)}

Mediante instruções gerais e exemplificação, a professora procura fornecer aos alunos informações para a realização da atividade. Essa categoria se reporta às circunstâncias em que - durante o preparo ou o jogo propriamente dito - a intervenção docente objetiva orientar a classe, explicando conceitos e procedimentos, bem como definindo fontes de informação. Inclui também registros em que a explicação é solicitada pelo(s) aluno(s). 0 aspecto central não é tanto o que a professora explica, mas como explica, indicando os vínculos afetivos que emolduram o clima interativo em sala de aula.

Vejamos um exemplo: "pode fazer perguntas pra pedir o diminutivo, o aumentativo, 0 plural, o antônimo... tudo que a gente tá vendo em Português vale. Ou pode pegar idéias dos cadernos, mas não vale copiar, heim?".

\section{2 - Observar (Observação Reflexiva e Complexidade Perceptiva)}

A categoria relaciona-se a comportamentos da professora para identificar e extrair informações acerca do que os alunos fazem. Observar não é um comportamento passivo, provém de questionamentos como também os propicia, na busca por elucidar aspectos percebidos e estabelecer hipóteses compreensivas. Essa observação não tem caráter diretivo ou de correção; orienta a ação seguinte agregando e organizando informações necessárias à adequada intervenção (mediando a aprendizagem e propiciando a ação autônoma das crianças). 0 mesmo tipo de comportamento pode se apresentar em diferentes momentos da atividade. Por exemplo, na avaliação conjunta da atividade, resulta de indagações aos educandos quanto a aprendizagens ocorridas durante o jogo.

Muitas vezes, os episódios de observação são definidos pelo comportamento não-verbal da professora, mas a comprovação de que se trata de uma observação mais ou menos reflexiva encontra-se na subseqüente verbalização, que retrata outra categoria. No fragmento transcrito aqui, a observação vem acompanhada de uma indagação da professora, através da qual ela problematiza o modo como os alunos procedem ao preparo do objeto lúdico (o trecho referente à observação está grifado. 0 referente à 
problematização está em negrito):

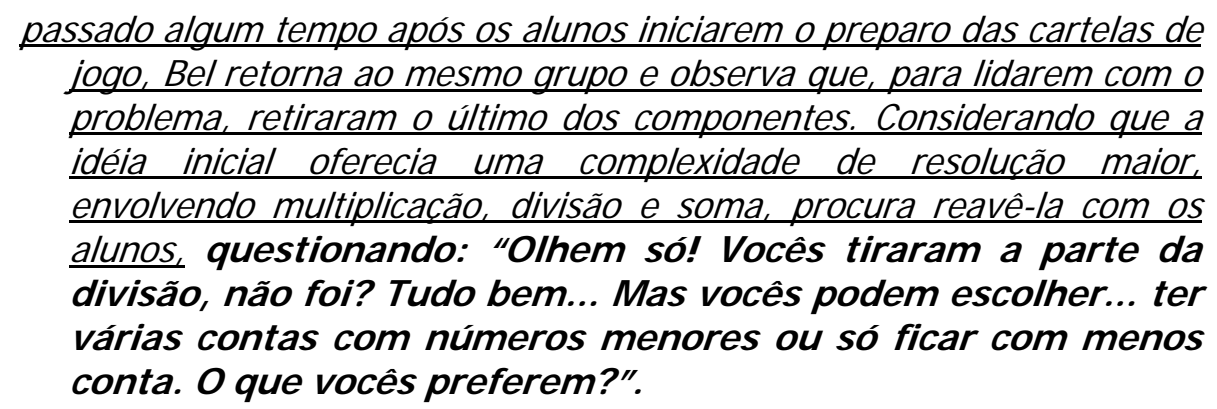

\section{3 - Problematizar (Conceituação Abstrata e Complexidade Simbólica)}

Nesta categoria estão representados três tipos de situações. No primeiro, a professora procura alertar os alunos sobre um procedimento que precisa ser revisto. No segundo, tem hipóteses de que um aluno, um grupo ou a classe inteira possa ir além daquilo que esteja explicitamente realizando, propondo novas formas de agir ou criando uma regra que torne a atividade mais complexa. No terceiro tipo, a professora propõe reformulações no desafio ou nas regras do jogo para que os conceitos escolares envolvidos sejam melhor sistematizados, definidos e articulados pelos alunos.

No exemplo acima, a parte enegrecida ilustra tal categoria.

\section{4 - Avaliar (Experimentação Ativa e Complexidade Comportamental)}

Esta categoria objetiva a identificação de ocasiões em que a professora coloca à prova conhecimentos dos alunos, recorrendo a variados meios, tais como: perguntas explícitas sobre desempenho no jogo; elaboração de texto, quadro, tabela, esquema, etc, para sumariar conteúdos implicados na atividade de jogo (mediante informações dadas pelas crianças) e na descrição sistematizada das regras que o compõem. Numa ocasião do jogo de Percurso, uma das professoras pergunta à classe: "mas pode andar quantas casas quiser? Assim, se fosse eu lá, eu ia andar até ganhar o jogo. O que precisa saber?". 
Quadro 4.3 - Temas e categorias de situações ludo-educativas com os alunos

\begin{tabular}{|c|c|c|c|}
\hline \multicolumn{4}{|c|}{ Temas } \\
\hline \multicolumn{4}{|c|}{ Organização do Cenário de Aprendizagem } \\
\hline 2 & \multicolumn{3}{|c|}{ Interação Social } \\
\hline 3 & \multicolumn{3}{|l|}{ Mediação pedagógica } \\
\hline 4 & \multicolumn{3}{|c|}{ Avaliação da aprendizagem e do desenvolvimento } \\
\hline \multicolumn{2}{|c|}{ Dimensões da Aprendizagem } & \multicolumn{2}{|c|}{ Categorias } \\
\hline \multicolumn{2}{|c|}{ Experiência concreta e complexidade afetiva } & & Explicar \\
\hline \multicolumn{2}{|c|}{ Observação reflexiva e complexidade perceptiva } & 2 & Observar \\
\hline \multicolumn{2}{|c|}{ Conceituação abstrata e complexidade simbólica } & 3 & Problematizar \\
\hline \multicolumn{2}{|c|}{ Experimentação ativa e complexidade comportamental } & 4 & Avaliar \\
\hline
\end{tabular}




\section{5 - ANÁLI SE DO DESENVOLVI MENTO PROFI SSI ONAL}

Este capítulo está dividido em duas partes: descrição analítica do desenvolvimento do projeto e análise do estudo de casos.

\section{1 - DESCRIÇÃO ANALÍ TICA DO PROJ ETO DE FORMAÇÃO}

Ao dar início à organização do material de análise, enfocamos o processo de cada participante do grupo, seu envolvimento, descobertas, anseios e receios, tentativas de experienciar a ludo-educação, explicações e questionamentos destinados à prática pedagógica norteada por meios lúdicos. Contudo, observamos, através da revisão das filmagens, que as diferenças no percurso das professoras têm características comuns; por isso, consideramos que o próprio processo formativo constitui-se num movimento ascendente e contínuo, cujas peculiaridades se intercruzam no processo vivenciado pelos componentes do grupo formativo, um a um.

A descrição da proposta formativa é fruto das análises preliminares do material. Para demarcar cada fase de desenvolvimento, partimos dos acontecimentos assinalados como mais significativos, tanto nas reuniões como na realização de atividades com alunos. Evidenciam-se três ocasiões em que os rumos do projeto foram mais decisivos, propiciando sua divisão em quatro fases. Cada fase espelha o conjunto de elementos indicativos de mudanças no modo pelo qual as professoras assumem a ludo-educação para (re)pensar seu próprio saber-fazer docente.

As fases simbolizam mudanças quantitativas e qualitativas na atuação das professoras. Segundo o que propõe Kolb, o desenvolvimento segue em direção à gradativa diferenciação e à integração hierarquizada. Com respaldo nessa proposição - e seguindo o critério de identificar transformações observáveis na postura das participantes na apropriação da ludoeducação - as fases correspondem, do ponto de vista quantitativo, ao incremento e à maior variedade de ações. Nosso interesse concentra-se particularmente nas ações que têm forte relação com o investigar, permitindo revelar núcleos de reflexão, conscientização e autonomia.

Conforme a acepção kolbiana, a complexidade da autonomia reflexiva demanda mais do que 0 aumento crescente em termos de quantidade; é igualmente qualitativa. A qualidade de refinamento, discriminação e elaboração das experiências e da formulação de conceitos dirige-se do estágio de indiferenciação para o de diferenciação e, paralelamente, da falta de unidade integrativa para a integração hierárquica, promovendo ampliação e sofisticação do autocontrole consciente sobre o comportamento. 
Do ponto de vista qualitativo, a identificação das fases visa demonstrar distinções em relação à diferenciação e à integração dos saberes docentes em torno da educação lúdica.

Durante os oito meses de execução do percurso de formação, realizamos: a) observações nas 9 classes, no início do ano letivo; b) 20 reuniões com o grupo formativo; c) 17 situações ludo-educativas, em que atuamos junto à professora e aos alunos, em sala de aula; d) entrevistas iniciais, finais e de feedback ${ }^{51}$ com as docentes, além de três reuniões com equipe de coordenação e de ocasiões em que participamos de algumas atividades escolares (reunião pedagógica e eventos culturais).

Não serão objeto de análise os episódios não estritamente relacionados ao percurso formativo das professoras, como as reuniões com coordenação e as ocasiões em que participamos da rotina da escola, em reunião pedagógica e eventos do calendário escolar.

Para cada fase elaboramos um quadro representando, seqüencialmente, reuniões (numeradas), atividades realizadas com as crianças e entrevistas com as professoras. Neles, apontamos também as ocasiões em que participamos da rotina escolar e as reuniões realizadas com coordenadores pedagógicos. Através de cores distintas, realçamos as diversas estratégias formativas, da seguinte maneira:

\section{Quadro 5.1 - Estratégias formativas}

\begin{tabular}{l|l} 
COR & DESCRITOR \\
\hline Preta & $\begin{array}{l}\text { ocasiões em que participamos da rotina escolar, em eventos não estritamente ligados ao projeto } \\
\text { formativo (não considerados na análise) }\end{array}$ \\
\hline Rosa & $\begin{array}{l}\text { entrevistas e encontros em que procedemos à coleta de informações junto às professoras, de } \\
\text { forma sistemática. A estratégia formativa tem o intuito explícito de obter dados acerca do } \\
\text { conhecimento do grupo com relação à educação lúdica. }\end{array}$ \\
\hline Azul & $\begin{array}{l}\text { encontros de planejamento de atividades lúdicas a serem realizadas junto ao corpo discente, em } \\
\text { sala de aula, com o intuito de aprendizagem de um determinado conteúdo curricular }\end{array}$ \\
\hline Verde & $\begin{array}{l}\text { encontros cuja intenção é avaliar as ações anteriores, discutir sobre estratégias e procedimentos } \\
\text { do projeto, reelaborar ou ampliar a proposta formativa }\end{array}$ \\
\hline Vermelha & ocasiões em que apoiamos as professoras na realização de atividades lúdicas junto aos alunos
\end{tabular}

No curso de desenvolvimento do projeto, a primeira evidência é a distinção postural de uma mesma professora e entre professoras, demonstrando níveis diferenciados de participação. Notamos que tais diferenças se acentuam: no início, presentificam-se em dois conjuntos de reuniões do grupo (cores rosa e azul) para serem, aos poucos, ampliadas para as demais reuniões (cor verde), até serem constatadas na atuação em sala de aula (cor vermelha). Refinando as interpretações, podemos clarear nossas impressões quanto à hipótese de que, fase a fase, as professoras, em diferentes níveis, apropriam-se das

\footnotetext{
${ }^{51}$ As entrevistas de feedback foram realizadas nove meses após finalizado o projeto formativo.
} 
características metodológicas e de noções teóricas da educação lúdica, à medida que:

$\Leftrightarrow$ tomam contato com objetos lúdicos e informações sobre ludo-educação (primordialmente na $1^{\text {a }}$ fase);

$\stackrel{\leftrightarrow}{\leftrightarrow}$ passam a atuar com os jogos, questionar e comparar a abordagem do ensino lúdico com a existente na escola ou com sua experiência profissional (primordialmente na $2^{\mathrm{a}}$ fase);

$\stackrel{\leftrightarrow}{\rightarrow}$ respondem ativamente aos desafios propostos de planejar e realizar atividades lúdicas para a aprendizagem com seus alunos (primordialmente na $3^{\mathrm{a}}$ fase);

$\stackrel{\leftrightarrow}{\rightarrow}$ implicam-se com a avaliação das experiências lúdicas, levantando implicações, questionamentos e análises dessas experiências a fim de integrá-las aos seus saberes docentes (primordialmente na $4^{\mathrm{a}}$ fase).

\section{1 - Primeira Fase}

A primeira fase corresponde ao conjunto de atividades que configuram simultaneamente envolvimento distanciado (não atuante) das professoras e alto grau de intervenção da formadora ${ }^{52}$. As professoras se mantêm atentas, embora tendam a aguardar 0 direcionamento da formadora, indaguem pouco e quase sempre com a finalidade de obter explicações de caráter restritivo quanto a procedimentos, materiais e técnicas relativas ao jogo educativo.

A característica central dessa fase é a inexistência de atividades lúdicas em sala de aula, em todas as séries/turmas, ou seja, a falta de vínculo direto com o corpo discente. Corresponde desde o contato para apresentação da proposta até a assessoria de "Jogos de Regras".

Essa fase espelha um momento de receio e ao mesmo tempo de expectativa. As participantes questionam-se sobre o que o projeto pode lhes oferecer, enquanto a formadora cumpre um duplo papel: utiliza jogos para sensibilizá-las e favorecer o exercício de sua própria ludicidade e assume a função de dirigir e estabelecer os objetivos das reuniões.

Descritivamente, a fase é composta como apresentado no quadro abaixo.

52 Os termos 'formadora' ou 'Alê' designam nosso papel no projeto formativo, objetivando melhor inteligibilidade na descrição dos episódios. 


\section{Quadro 5.2 - Primeira Fase do Projeto Formativo ${ }^{53}$}

\begin{tabular}{|c|c|}
\hline DATA & DESCRIÇÃO PRIMEIRA FASE \\
\hline $26 / \mathrm{mar}$ & Início do contato com os dois profissionais da equipe pedagógica \\
\hline $28 / \mathrm{mar}$ & (1) Contato com corpo docente para apresentação da proposta \\
\hline $04 / a b r$ & (2) Fio de Memórias - lembranças de brincadeiras de infância \\
\hline $11 / a b r$ & (3) Tangran - formação pessoal do educador \\
\hline 18/abr & (4) Espelho de Qualidades - reflexões sobre a identidade pessoal \\
\hline $25 / a b r$ & (5) Máquina de Aprender - desenvolvimento da criatividade \\
\hline $30 / a b r$ & Observações das nove turmas do Ciclo I (registro cursivo e em áudio) \\
\hline 02/mai & Entrevistas iniciais e individuais com professoras \\
\hline 09/mai & (6) Confecção de Fantoche - criação de histórias e personagens \\
\hline 16/mai & $\begin{array}{l}\text { (7) Apresentação e discussão sobre princípios dos jogos de regras: "Resta Um", "Dominó", } \\
\text { "História em Figuras" e "Jogo da Velha "Curiosa"” }\end{array}$ \\
\hline
\end{tabular}

Conforme o quadro, a fase está circunscrita pelas primeiras sete reuniões do grupo (em cores rosa e azul), realização das entrevistas iniciais com as professoras (rosa) e observações das classes (vermelho).

As reuniões são estruturadas de modo a provocar o debate sobre quatro temáticas: a) representações sobre educação, prática pedagógica, alunos; b) significados da função do jogo educativo; c) representações sobre a experiência profissional de cada docente; d) conhecimentos prévios sobre ludo-educação, nos níveis teórico e prático.

O conjunto 'rosa' de encontros tem a finalidade de fomentar o vínculo com o grupo, dar início às principais conceituações acerca de ludicidade e obter informações gerais sobre a prática pedagógica das professoras. Concomitantemente, levantamos aspectos relativos à profissionalidade de cada professora e ao conhecimento da dinâmica de trabalho do contexto escolar. Para alcançar este último objetivo, realizamos entrevistas semi-dirigidas com as participantes e observações em sala de aula.

O quadro também informa a ocasião em que realizamos observação de cada turma de todo o Ciclo I, no intuito de conhecer a dinâmica interativa de sala de aula, obtendo informações acerca das necessidades educativas que subsidiariam as diretrizes da proposta ludo-educativa.

Nas quinta, sexta e sétima reuniões (em azul), vislumbrando o desenvolvimento de competências relativas à escolha e adaptação de jogos e brincadeiras para o ensino, são realizadas atividades para as professoras vivenciarem sua própria ludicidade, construindo e fazendo uso de brinquedos e jogos que atendem a duas características: predomínio de situação imaginária (máquina de aprender e fantoche) e predomínio de regras (jogos de

53 Os números à frente dos itens em cores rosa, azul e verde referem-se aos encontros formativos. Nos demais quadros, dá-se seqüência a essa numeração. 
tabuleiro).

No quinto encontro, as professoras criam equipamentos fictícios, confeccionados com papel e outros materiais escolares, através dos quais o aprendizado vai se desenvolver. Em meio às apreciações e ao divertimento, o debate sobre os brinquedos criados possibilita às professoras explicitarem suas concepções de ensino e aprendizagem, como exemplifica a descrição de um dos dois modelos criados, apresentada por um subgrupo de professoras:

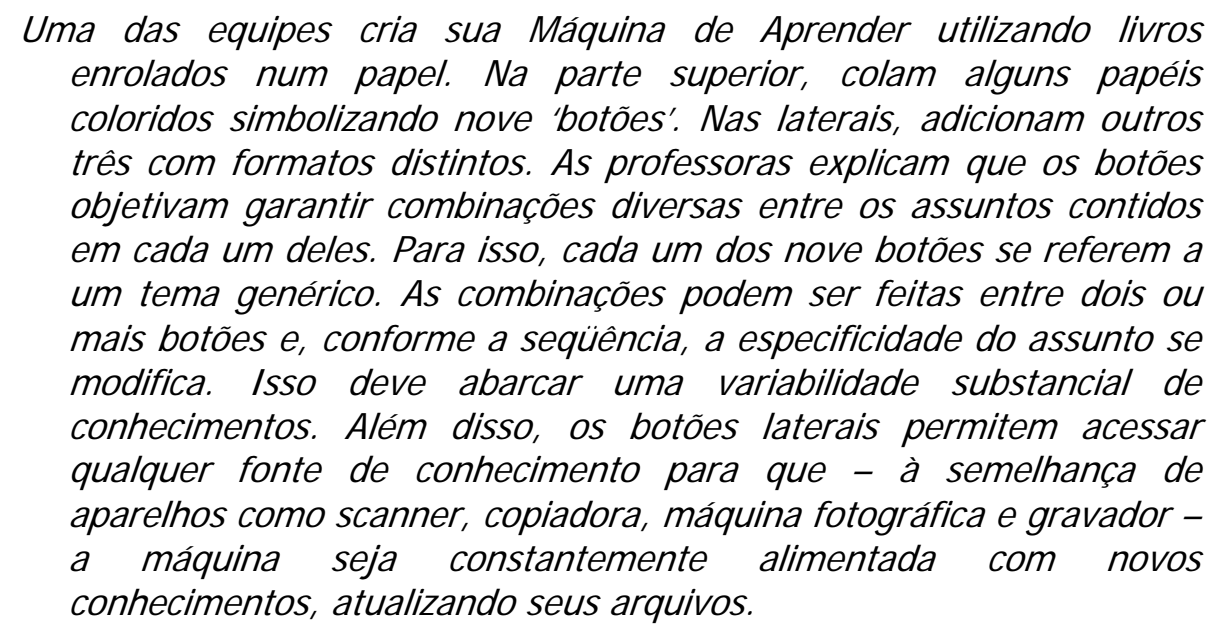

O exemplo ilustra como a obtenção de informação é o aspecto central da máquina. Sua operação é simples, basta combinar apertos de botões para o 'operador' (aluno) ser instruído sobre diversos assuntos. No diálogo sobre os brinquedos, a noção de transmissão de conhecimento prevalece, pois nas duas produções o usuário se posiciona passivamente na recepção de informações, havendo somente a possibilidade de selecionar as áreas de conhecimento. Contudo, dois aspectos importantes para o ensino lúdico são tematizados: a inclusão de informações sobre arte (pelo 'invento' do outro subgrupo) e o desejo de que 0 acesso ao conhecimento seja envolvente e prazeroso.

$\mathrm{Na}$ reunião seguinte, a confecção do fantoche de meia ${ }^{54}$ estabelece uma situação imaginária para o exercício da criatividade e da colaboração entre as professoras, favorecendo o clima afetivo do grupo. Também é um momento para avaliarem expectativas em relação às competências dos alunos, especialmente pela comparação entre as habilidades das crianças e as suas próprias. A maior parte do tempo é utilizada na confecção, inviabilizando realizar-se a discussão na mesma reunião. Somente através do encontro em que assistimos às filmagens torna-se possível observar quão significativa é a experiência, sobretudo porque as professoras apreciam suas próprias produções e notam que “parece uma coisa fácil pro adulto fazer, ...mas agora é que dá pra ver que é bem capaz

\footnotetext{
${ }^{54}$ Também conhecidos como 'bonecos de luva', pelo modo como são confeccionados (usando meia, saco, etc) e utilizados (veste-se a meia na mão, movimentando-se cabeça e braços do boneco com os dedos).
} 
de uma criança dar 'de dez a zero' na gente". Porém, essa opinião não é unânime. Algumas professoras se posicionam contrárias, justificando a inexistência de jogo na escola exatamente porque as crianças não têm condições de confeccioná-los, sendo ainda mais inviável comprá-los.

Para o último encontro dessa fase, selecionamos jogos com a finalidade de realizar-se amplo debate acerca de fatores cognitivos, sócio-afetivos e psicomotores implicados em atividades lúdicas regradas.

Em todos os encontros, o interesse das professoras está totalmente dirigido ao jogo em si ou às questões gerais da relação entre educação e jogo. Por não haver discussão especificamente dirigida aos vínculos de jogo educativo com prática docente, é negligenciado o exame das possibilidades reais de articular ensino à inserção de práticas ludo-educativas.

Contraposto ao nosso intuito original, julgamos impróprio solicitar às participantes a planificação e realização das aulas inserindo atividades lúdicas. Expressando insegurança e dificuldade em articular jogos ou brincadeiras que atendam os tópicos discutidos e os propósitos curriculares, a solicitação de nossa participação em todas as etapas de realização de experiência com jogo torna-se constante, especialmente para executá-lo junto ao corpo discente.

Por não termos previsto o apoio direto às professoras em classe, algumas mudanças são implementadas. A principal é constituir uma equipe de formadoras, contando com três auxiliares de pesquisa, graduandas do curso de Psicologia da USP, que demonstram conhecimentos e interesses alinhados com a proposta.

Assim, uma das alunas torna-se nossa parceira para filmar as reuniões e as intervenções lúdicas em sala de aula, enquanto a outra dupla se responsabiliza por apoiar, em classe, as professoras cuja participação aos encontros não é integral.

Essas mudanças - inserção de jogos em sala de aula e formação da equipe - produzem um salto de qualidade, estabelecendo uma nova etapa do projeto.

\section{2 - Segunda Fase}

A característica central dessa fase é o início de preparação, planejamento e realização das primeiras situações ludo-educativas junto aos alunos. Este momento do projeto é determinado por atitudes de: esperar orientação, seguir orientação, produzir poucas hipóteses e questionar a viabilidade das ações.

As professoras demonstram - mesmo com forte dependência da tutela da formadora compromisso com a prática. É um momento de experimentação, quando questionamentos voltados à ação prática predominam, sem que as relações com propósitos e conceitos da 
ludo-educação sejam estabelecidas. Em determinados momentos, discussões mais sofisticadas são realizadas, envolvendo caracterização do corpo discente e condições institucionais. No discurso das professoras, duas preocupações se sobressaem: uma delas se reporta ao fato de as classes serem numerosas, a outra diz respeito à falta de materiais e espaços adequados para se efetivarem os jogos.

Os encontros dessa fase são destinados especialmente ao planejamento e à avaliação das propostas ludo-educativas, conforme apresentado no quadro.

\section{Quadro 5.3 - Segunda Fase do Projeto Formativo}

\begin{tabular}{|c|c|}
\hline DATA & DESCRIÇÃO SEGUNDA FASE \\
\hline 28/mai & Participação em reunião pedagógica \\
\hline 06/jun & $\begin{array}{l}\text { (8) "Ludus Romanus: jogo de percurso" - com temática dirigida à teoria sobre jogos na } \\
\text { educação }\end{array}$ \\
\hline 08/jun & Festa Junina da Escola \\
\hline 13/jun & $\begin{array}{l}\text { (9) Apresentação e discussão de proposição de jogos a serem vivenciados com os alunos, em } \\
\text { sala de aula }\end{array}$ \\
\hline 14/jun & $\begin{array}{l}\text { (10) Apresentação e discussão de proposição de jogos a serem vivenciados com os alunos, em } \\
\text { sala de aula }\end{array}$ \\
\hline 17-19/jun & 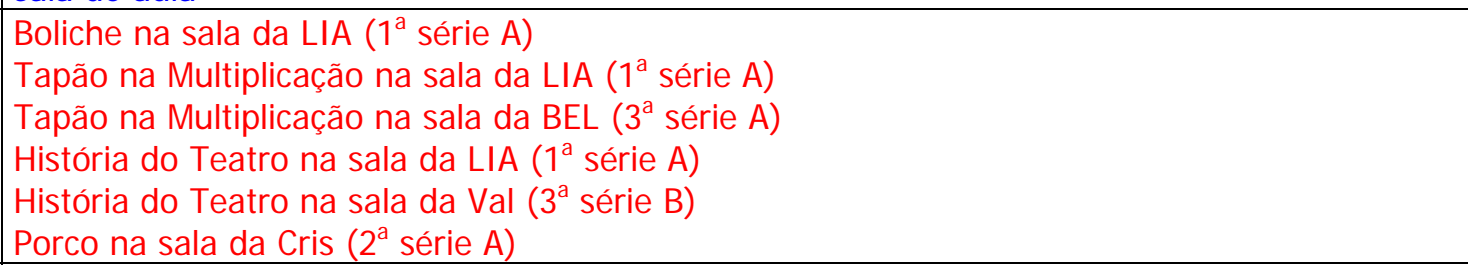 \\
\hline 20/jun & (11) Avaliação das atividades realizadas \\
\hline $27 / j u n$ & (12) Avaliação de seleção de episódios das videogravações \\
\hline $02-04 / j u l$ & $\begin{array}{l}\text { História do Teatro na sala da Ida ( } 3^{\mathrm{a}} \text { série } \mathrm{C} \text { ) } \\
\text { História do Teatro na sala da BEL ( } 3^{\mathrm{a}} \text { série } \mathrm{A} \text { ) } \\
\text { Porco na sala da Sara ( } 2^{\mathrm{a}} \text { série } \mathrm{B} \text { ) } \\
\text { Porco na sala da Rita ( } 4^{\mathrm{a}} \text { série } \mathrm{B} \text { ) }\end{array}$ \\
\hline
\end{tabular}

A fase está circunscrita por cinco encontros (nas cores rosa, azul e verde), além de dez sessões de atividade ludo-educativa com séries/turmas que compõem o Ciclo I (em vermelho) - especificamente nas que se mantém o vínculo da professora com o grupo formativo.

Na primeira reunião, a formadora propõe um jogo (Ludus Romanus - Jogo de Percurso) através do qual diversos conceitos relativos à ludo-educação são tematizados. A experiência das professoras com essa atividade inaugura a fase por ser o primeiro encontro em que sua atuação sobrepõe visivelmente a da formadora.

A utilização de um jogo para a formação, de forma homóloga ao que se pretende implementar na rotina de ensino, possibilita às professoras se responsabilizarem pela elaboração dos desafios lúdicos. Mediante excertos de textos, extraem informações para 
elaborar questões escritas que, posteriormente, são utilizadas durante a atividade a fim de rever e formar conhecimentos quanto ao jogo em geral e sua função no ensino.

O formato da estratégia é profícuo para o envolvimento das professoras com a elaboração das cartelas de perguntas e, sobretudo, no momento do jogo, para as discussões do grupo.

As informações obtidas durante a realização desse jogo oferecem-nos parâmetros de comparação quanto a ressignificações em curso.

Ao final desse encontro, a formadora propõe uma mudança de rumo, recomendando ao grupo que "já dá pra pensar em colocar na prática as coisas que a gente andou discutindo até aqui". O anúncio produz uma avalanche de interjeições e exclamações, sinalizações de expectativa e receio. Nesse emaranhado de sensações e percepções, uma das professoras salienta: "você (formadora) vai junto, né?".

Buscando amenizar o clima tenso, a formadora indaga se as professoras consideram necessário mais tempo, obtendo resposta negativa e a reafirmação de que é indispensável contarem com seu apoio em classe.

Resolutas e apreensivas, elas apostam no benefício desta nova configuração do projeto à sua atuação profissional. Todo o grupo se mostra ao mesmo tempo bastante interessado e receoso sobre como dar início de fato ao planejamento e à realização das práticas ludoeducativas.

O conjunto "azul" corresponde às reuniões de planejamento, quando o grupo se concentra nos jogos a serem realizados com as crianças, discutindo sobre os mais apropriados, em função da complexidade da atividade lúdica e das possibilidades de os relacionar a conteúdos específicos do programa curricular. Num clima de participação ativocolaborativa e contando com o auxílio da formadora, as professoras são desafiadas a criar estratégias e encontrar soluções acerca do planejamento das experiências ludo-educativas.

Considerando as especificidades de série/turma e contando com uma variedade de opções de jogos, as docentes concentram suas escolhas em características como: conhecimento pré-existente, facilidade de preparar, existência de um conjunto simples de regras e adequação a conteúdos, sobretudo nas áreas de Matemática e Língua Portuguesa.

O jogo de História do Teatro é o único proposto pela formadora, como forma de garantir que haja uma mesma atividade experienciada pelas professoras que participam integralmente do projeto (uma que leciona para turma de $1^{\text {a }}$ série e as três de $3^{\mathrm{a}}$ série).

$\mathrm{Na}$ realização de jogos com os alunos (em vermelho), é unânime a atitude das participantes de aguardar diretrizes, pistas e modelos da formadora. A ação docente restringe-se ao controle do comportamento. Em alguns casos, a professora permanece 
distante, sem se dirigir aos alunos, observando o envolvimento da turma com a proposta.

O conjunto "verde" refere-se às reuniões dedicadas à avaliação das experiências realizadas com os alunos. 0 debate com/entre as professoras é conduzido pelas reflexões quanto a: concepções sobre comportamento e desempenho dos alunos, representações sobre o papel da equipe pedagógica, condições institucionais para inserção de atividades ludo-educativas, características do jogo educativo. Algumas questões em relação às competências envolvidas com a especificidade do jogo educativo são abordadas, mesmo que superficialmente, tangenciando os fundamentos da abordagem da ludo-educação.

No décimo segundo encontro, as gravações em vídeo são o instrumento formativo privilegiado para sistematizar as atividades realizadas e possibilitar que, pelo debate, sejam definidos os próximos encaminhamentos do projeto formativo. A formadora apresenta uma seleção de episódios e propõe que a discussão se apóie nos seguintes critérios de observação das ações discente e docente: envolvimento com a atividade; experiência de aprendizagem (durante/após a atividade); iniciativa; autonomia; participação colaborativa; criatividade e existência/qualidade de registros dos alunos (escrito, desenhos, oral, gestual).

Mediante a observação de como as professoras agem, do que falam e como falam, evidenciam-se as primeiras distinções na forma pela qual a ludo-educação constitui-se referência para suas reflexões. No grupo, de modo geral, a qualidade da participação nas reuniões é muito superior ao que ocorre em sala de aula. Entre os três tipos de reuniões também há distinções. As professoras manifestam maior desenvoltura para questionar, fornecer exemplos e propor encaminhamentos nas reuniões dos conjuntos 'rosa' e 'azul'.

Nos encontros de avaliação, as reflexões são bastante incipientes. A atitude predominante é de apreciação, pela qual se acentua a valorização do jogo como potencializador de aprendizagem.

\section{3 - Terceira Fase}

O início dessa fase é estabelecido por uma nova mudança de desenvolvimento do percurso formativo. Ao contrário da fase anterior, essa etapa não decorre de decisões da formadora, mas de atitudes das professoras, que passam a intervir de modo efetivo na caracterização do projeto. Expressam opiniões, comparam com as experiências realizadas, compartilham idéias, etc. Disso resultam posicionamentos mais seguros e independentes nas reuniões e, em alguns casos, na atuação em sala de aula. Em função disso, as reuniões de planejamento passam a ser mais delineadas em função das opiniões e sugestões das professoras do que por orientações da formadora. Entretanto, mantém-se forte dependência de orientações da formadora em reuniões de avaliação e nas atividades lúdicas realizadas 
junto aos alunos.

\section{Quadro 5.4 - Terceira fase do projeto formativo}

\begin{tabular}{|c|c|}
\hline DATA & DESCRIÇÃO TERCEIRA FASE \\
\hline $04 / j u l$ & (13) Avaliação parcial do projeto - fechamento do primeiro semestre \\
\hline $30 / j u l$ & Reunião com coordenadores pedagógicos para reinício das atividades \\
\hline 01/ago & $\begin{array}{l}\text { (14) Reorganização do cronograma e alteração das propostas juntamente com o corpo docente } \\
\text { diretamente envolvido com a pesquisa }\end{array}$ \\
\hline 08/ago & $\begin{array}{l}\text { (15) Apresentação de vídeo sobre jogos educativos e preparação do "J ogo de Percurso" para ser } \\
\text { realizado em sala de aula }\end{array}$ \\
\hline 15/ago & Ensaio da peça "Cinderela" a ser apresentada pelos professores aos alunos \\
\hline 21-22/ago & $\begin{array}{l}\text { Jogo de Percurso (ludo) na sala da BEL ( } 3^{\text {a }} \text { série } A \text { ) } \\
\text { Jogo de Percurso (ludo) na sala da LIA ( } 1^{\text {a }} \text { série A) } \\
\text { Jogo de Percurso (ludo) na sala da Ida ( } 3^{a} \text { série C) } \\
\text { Jogo de Percurso (ludo) na sala da Val ( } 3^{\text {a }} \text { série } B \text { ) }\end{array}$ \\
\hline
\end{tabular}

A fase circunscreve-se por três encontros do grupo formativo (dois de avaliação do projeto, em verde, e um de planejamento) e quatro sessões de atividade ludo-educativa realizadas somente com as séries/turmas em que a professora respectiva mantém vínculo constante com o grupo formativo (as três de $3^{\text {a }}$ série e Lia, da $1^{\text {a }}$ série). Comporta desde a reunião de avaliação parcial do primeiro semestre até o encontro dedicado ao ensaio de uma peça teatral a ser apresentada pelas docentes aos alunos do Ciclo I, no início de setembro.

No início do $2^{\circ}$ semestre letivo, ocorrem importantes modificações do projeto pelo grupo para atender às necessidades educativas nas áreas de Língua Portuguesa e de Matemática. Durante 0 encontro, as professores manifestam atitudes que insinuam autonomia sobre seu processo formativo. Comparando as atividades realizadas às suas expectativas iniciais, elas se reportam à ludo-educação através de questionamentos, propostas, convergência e divergência de opiniões e representações acerca do ensino e das condições institucionais do contexto escolar. É um momento importante de tomada de decisões, não somente relativas à inserção de jogo em sala de aula, mas também para a ocupação de outros espaços da escola, com atividades extraclasse.

As interações entre coordenação pedagógica e docentes estabelecem novas perspectivas de trabalho conjunto. Propõe-se, por exemplo, que as próprias professoras apresentem uma peça de teatro a seus alunos, sendo um resultado interessante e inesperado do jogo de História do Teatro, realizado em classe.

As discussões iniciadas no $13^{\circ}$ encontro são retomadas no início do segundo semestre com maior profundidade, rumo à autonomia na gestão de práticas ludo-educativas. Animadas com as novas perspectivas, as professoras tomam a direção da reunião para 0 planejamento das próximas linhas de ação e estratégias do projeto. 0 papel da formadora, 
agora, limita-se às sugestões pontuais, ao incentivo da organização das idéias e à proposição de problemas, procurando intervir nas circunstâncias em que a discussão pareça lacunar ou contraditória à diretriz ludo-educativa.

Todavia, alguns aspectos permanecem lacunares. O debate focaliza sobretudo os procedimentos de preparo, a estruturação das regras e a organização da execução, sem envolver o exame metacognitivo da atuação docente, que propiciaria aprofundar a compreensão e elaboração de princípios gerais da ludo-educação.

No encontro de planejamento, a atitude colaborativa e cooperada prevalece. A familiaridade com o jogo de Percurso e as experiências anteriores de atividades lúdicas em sala de aula oportunizam às professoras se perceberem melhor preparadas para definir metas e mais independentes para assumir a prática ludo-educativa.

Em sala de aula, há forte distinção na maneira como cada professora executa o jogo. Duas delas (de $3^{\mathrm{a}}$ série) mostram-se flexíveis, empenhando-se em se posicionar como orientadoras do processo, intervindo somente para assegurar que a atividade alcance as metas educativas que definem sua estruturação. A outra professora de $3^{\mathrm{a}}$ série e a de $1^{\mathrm{a}}$ série tendem a manter a diretividade sobre a ação discente. Essas diferenças apresentam-se sobretudo nos momentos de preparo e de execução do jogo. Em contrapartida, poucas mudanças são observadas na etapa de avaliação do jogo; em todas as turmas, as professoras seguem parâmetros distintos à diretriz ludo-educativa, inexistindo o incentivo à autonomia discente.

Em correspondência ao modo como as professoras se apropriam da prática ludoeducativa, há grande diferença na qualidade da ação discente, embora o intenso envolvimento esteja presente em todas as classes. Nos casos em que as mediações das professoras se definem pela orientação não-diretiva, por maior número de problematizações do que de explicações e pela observação próxima de cada grupo de alunos, é perceptível como a atividade contribui para a aprendizagem dos conteúdos escolares.

\section{4 - Quarta Fase}

Nesse momento, as preocupações das professoras dirigem-se à sistematização e ao refinamento de noções conceituais. No planejamento e na avaliação do jogo, têm maior domínio sobre o formato das experiências lúdicas, participam nas decisões e análises sobre 0 trabalho, além de demonstrarem maior sensibilidade para flexibilizar a execução do jogo conforme as especificidades de suas respectivas turmas.

A realização da atividade ludo-educativa também apresenta importantes mudanças. Diminui a necessidade de contar com o apoio da formadora, embora haja diferenças entre as 
professoras quanto à autonomia.

O eixo fundamental é a consolidação de alguns aspectos essenciais da ludo-educação, demonstrando avanços no desenvolvimento profissional. As professoras aproximam-se da perspectiva ludo-educativa, com momentos ascendentes e descendentes, mas sempre em direção a uma reflexão mais profunda e maior articulação entre metas educativas e planejamento, realização e avaliação da prática ludo-educativa.

\section{Quadro 5.5 - Quarta fase do projeto formativo}

\begin{tabular}{l|l} 
DATA & \multicolumn{1}{|c}{ DESCRIÇÃO QUARTA FASE } \\
\hline 22/ago & (16) Discussão sobre resultados obtidos com o uso do "J ogo de Percurso" em sala de aula \\
\hline 31/ago & Apresentação da peça encenada pelo corpo docente participante da pesquisa \\
\hline 05/set & (17) Preparação do jogo "Tapão na Matemática" e discussão sobre instrumento de observação \\
\hline 11-12/set & $\begin{array}{l}\text { Tapão na Matemática na sala da BEL ( } 3^{a} \text { série A) } \\
\text { Tapão na Matemática na sala da Ida (3a série C) } \\
\text { Tapão na Matemática na sala da LIA (1 } 1^{a} \text { série A) }\end{array}$ \\
\hline 12/set & $\begin{array}{l}\text { (18) Avaliação de resultados obtidos com o uso do "Tapão na Matemática" em sala de aula, a } \\
\text { partir dos registros do protocolo do instrumento de observação }\end{array}$ \\
\hline 26/set & (19) Avaliação de resultados das atividades realizadas no segundo semestre \\
\hline 26/set & Reunião com coordenadores pedagógicos (Eli e Ori) \\
\hline 03/out & (20) Análise sobre episódios selecionados, de atividades realizadas neste semestre \\
\hline 03/out & Reunião com coordenadores pedagógicos (Eli e Ori) \\
\hline 08/out & $\begin{array}{l}\text { Término do projeto com apresentação de resultados gerais aos demais professores, com uso de } \\
\text { vídeos }\end{array}$ \\
\hline 10/out & $\begin{array}{l}\text { Entrevistas finais com cada um dos professores participantes, exceto com a professora Val, que } \\
\text { deixou a escola no início de setembro. }\end{array}$ \\
\hline Jul/2003 & Entrevistas de feedback do material com professoras BEL, LIA e Ida
\end{tabular}

Conforme o quadro, a fase envolve quatro encontros avaliativos (verde), um encontro de planejamento de jogo (azul), prática ludo-educativa realizada em três classes (vermelho) e o conjunto de entrevistas final e de feedback (rosa) - as primeiras, realizadas na última semana de contato com a escola e, decorridos nove meses, as que marcaram o retorno de material para as professoras revisarem, complementando e ajustando.

Esta etapa, como a anterior, também é inaugurada por um encontro de avaliação, demonstrando que as estratégias que definem tais encontros propiciam às professoras sistematizarem de maneira mais complexa e definida suas interpretações das vivências lúdicas. A discussão é relativamente densa, tornando esses encontros prioritários para a reflexão sobre a ação.

No segundo encontro da fase, é planejado o jogo do Tapão na Matemática. Tanto o planejamento quanto a realização da experiência ocorrem com maior independência, por parte de docentes e alunos, confirmando uma mudança significativa das relações estabelecidas entre jogo e aprendizagem formal. 
Na décima oitava reunião, a formadora propõe que as reflexões sejam orientadas por um instrumento de observação, cuja finalidade é aprofundar as análises, relacionando-as com princípios ludo-educativos. Diferentes conceitos são definidos e redefinidos, o debate se especializa e a formação de novos conhecimentos se potencializa.

As diferenças entre as professoras refletem-se em maior grau em aspectos relacionados à caracterização do jogo. No entanto, a conceituação generalizada e abstrata é ainda bastante precária; alguns conceitos se embasam na concretude de exemplificações e observações, outros não chegam a ser postulados ou são constituídos por idéias contraditórias.

No conjunto das fases, considerando as três professoras de $3^{\text {a }}$ série e uma das professoras de $1^{\text {a }}$ série - cuja participação no projeto foi integral - há três focos de similaridade entre o desenvolvimento do percurso formativo e o das professoras. São eles:

$\stackrel{\leftrightarrow}{\rightarrow}$ assim que a realização de jogo com os educandos passa a orientar as reuniões, 0 projeto se torna melhor sistematizado e, por conseguinte, as reflexões das professoras focalizam elementos da prática ludo-educativa essenciais para redimensionar sua atuação pedagógica;

$\stackrel{\leftrightarrow}{\leftrightarrow}$ a avaliação do projeto, ao final do primeiro semestre, é caracterizada pela tomada de decisões que influenciam diretamente no enquadramento das estratégias formativas e na atuação das professoras, cabendo à formadora um novo papel: fornecer elementos para sustentar as novas necessidades que surgem em decorrência dessa reestruturação;

$\stackrel{\leftrightarrow}{\leftrightarrow}$ a avaliação metacognitiva das experiências lúdicas é efetivamente produzida após a experiência com o jogo do Percurso. Apesar de terem vivenciado outras reuniões de avaliação anteriormente, somente nesta as professoras formulam noções gerais sobre a utilidade do jogo educativo. Os questionamentos e as hipóteses que elaboram têm um nível de conscientização mais amplo e de maior qualidade. A avaliação desse jogo transforma a prática subseqüente. Ao planejarem e realizarem a próxima atividade lúdica, as professoras se respaldam nas discussões que edificaram o significado de jogo como instrumento mediador de aprendizagem escolar. O jogo deixa de ser jogo simplesmente, tornando-se objeto de reflexão de como pode ser vinculado aos conteúdos escolares.

As fases espelham esse processo de mudança, com diferenças entre as professoras em termos de complexidade dos questionamentos, qualidade de solução de problemas, nível de autonomia para o exercício da ludo-educação e conscientização sobre sua atuação profissional.

A atuação das professoras no projeto deriva, em parte, da distinção entre cada ser 
singular, suas experiências passadas, a história de seu percurso profissional e sua familiaridade em relação ao jogo educativo, além do modo como participam do projeto: algumas professoras comparecem a todas as reuniões e realizam as atividades lúdicas propostas com seus alunos; outras participam apenas das reuniões; outras, ainda, comparecem a muitas das reuniões e nem sempre realizam as atividades, além daquelas que deixam a escola durante 0 ano letivo.

A partir da caracterização do projeto em fases, percebemos mudanças rumo à apropriação da concepção lúdica de ensino. Mas como essas mudanças se definem e repercutem na experiência pessoal/profissional de cada professora? Como são experienciadas na relação das professoras com seus alunos? Em que níveis se modelam? Buscando a trama de articulação entre desenvolvimento profissional e percurso formativo, questionamos sobretudo se mudanças quanto a planejamento, realização e avaliação de atividades ludo-educativas promovem processos reflexivos quanto à profissionalidade de cada professora, e em que grau de significação.

Os diversos elementos levantados e a qualificação de cada momento do percurso mostram-se imprescindíveis para indicar caminhos, perguntas e hipóteses sobre 0 desenvolvimento profissional no contexto da formação. Entretanto, não são suficientes para a investigação do desenvolvimento profissional, determinado por uma multiplicidade de fatores cuja compreensão depende tanto do conhecimento profundo sobre cada um deles quanto da rede de inter-relações que os integra.

O tempo do projeto realizado é insuficiente para mudanças mais integradas e solidificadas. Por isso, o processo de análise inicia pela identificação das fases e se aprofunda pelo estudo de casos, tornando viável estabelecer como se edificam alterações mais sutis, porém de extrema relevância para estabelecermos em que medida a proposta de formação contribui para o desenvolvimento profissional das professoras.

\section{2 - ANÁLISE DO ESTUDO DE CASOS}

O estudo aborda dois microssistemas (duas professoras e suas classes) dentro de um mesossistema (relações do trabalho realizado no grupo formativo com a prática das professoras com seus alunos). Essa opção não fragmenta a análise, pois não ignoramos o conjunto das docentes do Ciclo I e o contexto de trabalho nem as relações com o sistema educacional. Tais conexões são intrínsecas à atividade docente das professoras e de suas respectivas turmas.

Referenciada na abordagem da Aprendizagem Experiencial de Kolb, a análise propõe as seguintes perguntas: 
O projeto formativo contribui para o desenvolvimento profissional? Em que sentido? Em que nível? Atende às necessidades da prática docente? A proposta de educação lúdica é incorporada na rotina de ensino? De que maneira as educadoras se apropriam dela?

Apropriação tem sentido de ação consciente e autônoma, e desenvolvimento profissional é um processo complexo. Esses dois conceitos alertam para o fato de que o percurso de formação realizado baseia-se no desenvolvimento em curso, no alcance de metas parciais.

Nosso interesse está sobretudo nas primeiras mudanças, no princípio de um processo consciente de reflexão, que ainda não tem caráter completo e duradouro. Dirigir o olhar para o desenvolvimento potencial envolve compreender formação como processo permanente de reflexão sobre e na prática pedagógica.

O fato de enfocarmos as mudanças iniciais e ainda precárias em direção a uma prática reflexiva tem valor metodológico para a área de formação de professores, sedimentada na perspectiva de desenvolvimento profissional. Metaforicamente, o início de um processo de transformação da profissionalidade simboliza o momento imediatamente anterior de uma importante modificação no desenvolvimento da criança, antes de seus primeiros passos, das primeiras palavras com sentido ou da escrita comunicativa.

O contínuo da profissionalidade segue trilha semelhante. Períodos de mudanças se alternam com períodos de resistência. Em alguns, o desenvolvimento profissional ocorre sem que haja atividade sistemática, visando à formação. Há períodos de recuo, paralisação, descrença ou dificuldades - derivados do contexto de trabalho ou do momento particular e pessoal do docente, distanciados de ações voltadas ao questionamento reflexivo de sua prática pedagógica - além de períodos vinculados a ações sistemáticas de formação.

$\mathrm{Na}$ análise de uma experiência inicial é indispensável atenção detalhada para não incorrer em interpretações apressadas sobre o desenvolvimento profissional e ser possível identificar os aspectos em que estejam ocorrendo transformações, sobretudo as mais sutis.

Esses apontamentos delimitam o escopo de nosso estudo mais nos indícios de desenvolvimento do que na efetiva apropriação da ludo-educação. Refere-se a processos em 'amadurecimento' de caráter teórico e prático, relativos mais ao desenvolvimento potencial do que ao desenvolvimento real na profissionalidade docente.

\subsection{1 - Entrevista inicial}

\section{A professora Lia}

Lia, formada em Pedagogia há dezoito anos, é professora de uma das duas turmas de $1^{\text {a }}$ série. Iniciou a carreira numa creche municipal paulistana, por meio da qual realizou cursos sobre desenvolvimento infantil, destacando o aprendizado da teoria de Emilia Ferreiro como 
um dos mais significativos para sua atuação, sobretudo numa série em que é vital "conhecer os estágios da alfabetização". Tomou contato com experiências inovadoras na área, citando a Escola da Vila como uma referência para sua formação. Fez especialização na área de orientação educacional, assumindo o cargo de coordenadora de grupo de formação de professores do NAE 12, prestando orientação para diversas creches da região (Butantã). Há onze anos é professora efetiva nessa escola.

Desde nosso primeiro contato, Lia se destaca pelo bom humor e extroversão. No grupo formativo, é ela que geralmente inicia um assunto a ser discutido. Sua segurança e a ênfase com que expressa suas opiniões tendem a fortalecer sua imagem diante das demais professoras, que respeitam e apoiam as idéias que lança e as explicações que formula.

Lia gosta muito do que faz. Para ela, ser educadora é experimentar sempre situações novas. "Não existe rotina; cada dia, cada ano sempre é diferente". Reconhece muito bem os desafios, sabendo discernir entre os que é capaz de superar por conta própria e os que exigem envolvimento de outras esferas. Ressente-se especialmente da desvalorização da profissão, expressa pela falta de condições melhores de trabalho, destacando a falta de “material de apoio, equipamentos e até mesmo de pessoal, porque faltam professores e a escola acaba tendo que conviver com uma mudança constante de professores substitutos, não dá pra formar uma equipe".

Outro fator com que se preocupa refere-se ao número de crianças/turma. No seu caso, comenta que este ano "foi sorte só ter trinta e sete. Tem anos que é quarenta e tantos".

Sua turma atual é composta, na grande maioria, de crianças da comunidade próxima à escola, um bairro violento e com pouquíssimos espaços públicos adequados para as crianças e os jovens. Lia acentua que este contexto sociocultural influencia a educação anterior à chegada das crianças à escola. Por isso, admira-se por ter uma turma interessada e participativa. Apesar dessas qualidades, avalia que o problema que the causa maior preocupação é a dificuldade dos alunos em "memorizar os conceitos e fazer cálculo mental".

Aos poucos, conhecemos melhor as razões dessa avaliação de Lia. Ao contrastar os perfis dos alunos, ela explica que o melhor aluno "é alfabético, participa das aulas, é organizado, compreende regras", enquanto aqueles que exigem atenção e esforço redobrados "têm dificuldades para compreender os comandos dos exercícios e regras, são apáticos, não expõem suas idéias. Não se sabe o que estão pensando".

Em relação ao programa curricular da série, Lia considera que as mudanças mais recentes do sistema educacional brasileiro, especialmente o processo de avaliação, permitem ao professor se envolver mais profundamente com o processo de ensino, mais do que com averiguação de resultados. Contudo, colocar essa perspectiva em prática não é fácil, 
não pode ser mecânico e acaba gerando uma variação enorme como cada um interpreta. Eu sempre fui de anotar tudo que faço. Tem professor que não se adapta a isso, perde a noção do processo. Como eu já fazia caderno de registro, só trouxe mais respaldo ao que já fazia.

Lia tende a concentrar nas disciplinas de Língua Portuguesa e de Matemática os assuntos fundamentais de $1^{a}$ série. "Como é o primeiro ano escolar, a preocupação central é o conhecimento de letras, sílabas, numerais até o 99, durante o ano todo".

Por ser foco central do projeto, na primeira entrevista com Lia indagamos sobre o que ela conhecia acerca do jogo educativo, tanto em relação à linha teórica quanto à prática da ludo-educação.

Para Lia, a abordagem histórico-cultural é conhecida, pelo menos em relação a conceitos mais divulgados. Ela cita a importância desse referencial para que o educador tenha um olhar prospectivo da aprendizagem, "esteja sempre avaliando as potencialidades dos alunos, porque é com elas que o aluno vai superar as dificuldades". Entretanto, a conceituação específica com relação ao jogo é desconhecida pela professora, fator que destaca como contribuição que espera obter pelo projeto.

Em sua prática, Lia costuma utilizar jogos voltados para conteúdos de ensino, como dominó de letras e de números, bingo e brincadeiras como forca. Relata que o jogo "consegue envolver todas as crianças". Durante a entrevista, solicita algumas indicações sobre jogos específicos, com os quais pretende desenvolver conteúdos de matemática, o cabo-de-guerra "de soma" e o boliche, obtendo um catálogo em que tais jogos são descritos: objetivo, regras, procedimentos de confecção e meios para inseri-los no ensino ${ }^{55}$.

Com relação a cursos e outras atividades da formação profissional de Lia, somente em duas ocasiões teve contato com o tema específico de jogos educativos. Num evento realizado pela prefeitura, houve um "Sarau de Jogos", com ênfase em brincadeiras que não utilizam materiais. A segunda ocasião foi uma oficina de dobraduras.

Quanto a bibliografias sobre jogos, Lia conheceu dois livros por intermédio de sua colega e também professora de $1^{\text {a }}$ série: “'Aprender com Jogos e Situações Problema' e 'Atuação Psicopedagógica e Aprendizagem Escolar'", sem se recordar dos autores ou destacar algum aspecto significativo.

Em relação a jogos que tenha aprendido e utilizado, menciona um jogo de matemática, em que as cartas de um baralho comum são utilizadas para adição e subtração.

${ }^{55}$ Este catálogo foi elaborado por conta de experiências anteriores da pesquisadora/formadora, noutras escolas de Ensino Fundamental, constando descrição de jogos confeccionados por alunos com uso de sucata. 


\section{A professora Bel}

Bel, professora de uma das três turmas de $3^{\text {a }}$ série, terminou o curso de Magistério em 1995. Em 2001, iniciou a licenciatura em História na Universidade de São Paulo, o que, para ela, é "a mais importante experiência da minha trajetória profissional, até agora".

Há sete anos, iniciou a carreira na Educação Infantil, período que considera enriquecedor para sua formação, avaliando que as crianças pequenas a ajudaram a "ser menos tímida". Depois de três anos, deixou a educação de primeira infância para atuar durante um ano como professora substituta da disciplina de História, no Ciclo II, antes de iniciar os estudos universitários nessa área. Desde 2000 é professora titular do Ciclo I. Sua vinda para esta escola só ocorreu no ano anterior à execução do projeto (2001), lecionando para a $2^{\text {a }}$ série do Ensino Fundamental I.

Bel informa que sua turma é formada por 38 crianças, das quais praticamente a metade foram seus alunos de segunda série.

Ela não sabe quais os critérios para formação das turmas, pois o corpo docente não participa diretamente do processo. Recorda-se de que, durante as primeiras semanas do ano letivo, passou por um constrangimento "bom de se sentir", quando teve de lidar com vários pedidos e reclamações de ex-alunos que não fazem parte de sua classe atual para que os aceitasse na nova turma. Lembra-se de que eles se ressentiram de não tê-la mais como professora. Houve ocasiões em que a interpelavam pelos corredores, indagando "por que eu não gostava deles?!!". Durante um tempo, foi comum um ou outro "aparecer na porta da minha sala querendo entrar" ou haver mães intercedendo por sua inclusão na turma, o que deixa evidente a vinculação afetiva entre os alunos e ela.

Desde nossa primeira conversa, num tom marcado pela serenidade e introversão no falar, Bel deixa claro que pretende atuar na área de ensino assim que se formar (2004), mesmo prevendo que sentirá "saudades dessa meninada".

Com relação à profissão, Bel destaca o fato de "lidar com o ser humano, ver como as crianças aprendem" o que mais a realiza como professora. Em contrapartida, é difícil ter de conviver diariamente com "profissionais que se acham melhores que os outros só porque têm mais tempo no cargo... Nesta escola, eu não gosto do distanciamento... é cada um por si."

Em relação à turma, Bel destaca que são alunos participativos, interessados, mas

também são agitados. Existe uma grande amizade entre as crianças, pois a maioria mora perto e também já vem estudando junto desde 0 ano passado... Eles possuem uma energia muito grande. Gostam de cantar músicas com expressão corporal, e tudo que eles possam se movimentar é motivo pra entusiasmo geral. 
Menciona que sua "maior preocupação é a defasagem de alguns alunos em relação ao restante da sala". Para ela, é necessária uma dedicação maior para que possam acompanhar os demais...

\section{entrar no ritmo leva tempo, mas não pode descuidar de tentar evitar que essas crianças não sejam discriminadas ou excluídas do grupo. Acredito que o grupo não discrimina essas crianças, mas elas, às vezes, se sentem assim... não sei se consegui me explicar bem!}

Na visão dessa professora, só uma circunstância a deixa 'irritada': “quando o aluno sabe que tem problema de aprendizagem, precisa se esforçar, mas brinca direto na sala e é muito desatento". Nas observações que fizemos logo nas primeiras semanas de convivência, não foi possível registrar situações em que Bel demonstrasse irritabilidade com os alunos, mesmo em relação aos que havia indicado como brincalhões e desatentos. Sua voz tornou-se forte e altiva, inversamente ao que ocorreu durante a maior parte do projeto nas reuniões do grupo formativo, sobretudo até a terceira fase.

Com sua maneira peculiar de iniciar ou finalizar o diálogo, duvidando ter se expressado adequadamente, Bel diz contar com vários alunos

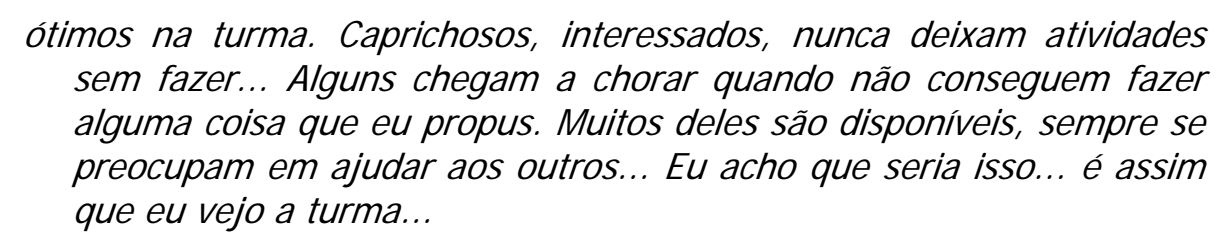

Ela informa que teve de procurar por conta própria as informações sobre os conteúdos da $3^{\text {a }}$ série. Em algumas ocasiões, a coordenadora a orientou sobre as normatizações institucionais, avaliações dos alunos, contato com os pais e regime de reuniões pedagógicas. Cita, dentre os conteúdos previstos para o primeiro semestre letivo, assuntos das áreas de ciências e de estudos sociais (corpo humano e meio ambiente, respectivamente), além da "multiplicação de dezena e centena para matemática... não sei se teria algum jogo envolvendo isso... e, para português, paragrafação e pontuação." Prevê, na continuidade do ano, a "aprendizagem de divisão, por dezenas... acho que seria bom ter jogo envolvendo a geometria, que vai começar no segundo semestre. Também daremos continuidade ao Projeto de Poesia das três $3^{\mathrm{a}}$ séries".

Quanto ao Projeto de Poesia, Bel explica que se trata de uma articulação entre as professoras da série para que os alunos conheçam diversos textos da literatura nacional, de autores de renome, e venham a produzir seus próprios textos poéticos, que constituirão material de um livro ao final do ano.

Em relação à proposta do projeto, Bel diz ter um conhecimento superficial da teoria 
histórico-cultural. Seu contato com jogos, em cursos, atividades complementares de formação ou leituras foi bastante restrito. Não se recorda do título, mas sabe que leu um livro em que se destacava a importância do jogo para aprendizagem de crianças menores de seis anos. Também cita uma oficina didática realizada há algum tempo, em que os jogos eram retratados como situações-problema. Após um momento em silêncio, Bel fala num tom bastante baixo: “Eu acho que, na época, eu só percebi que era importante associar jogo com criação de situação-problema, mas não entendi mais nada... nem como, nem por quê".

0 desconhecimento das razões de vincular atividades lúdicas ao ensino não a impediu de ter algumas informações de experiências das outras professoras com uso de jogos, sobretudo tangran, de memória, stop e forca. Bel acrescenta que, desde então, passou a se questionar sobre como poderia atribuir a eles uma significação maior, torná-los parte integrante do planejamento, o que espera tornar factível com o projeto de ludo-educação.

\subsection{2 - Primeiros contatos com o corpo discente}

Logo no início do projeto, solicitamos permissão às professoras para entrarmos nas salas e conhecermos os alunos a fim de nos apresentarmos e observarmos a dinâmica em duas ocasiões distintas, em cada classe.

Na primeira visita, sem equipamentos de registro, permanecemos em sala do início ao fim de uma mesma atividade. Além de informações sobre atuação pedagógica, coletamos dados sobre participação e produção dos alunos. Como prevíamos, nossa presença desperta a curiosidade dos alunos, que se dirigem até nós para mostrar seus cadernos e contar o que estão aprendendo.

$\mathrm{Na}$ segunda visita, utilizamos um gravador e mantivemos o registro cursivo das atividades, atuação da professora e produções dos alunos. Neste retorno, procuramos acompanhar aulas de áreas curriculares não observadas antes.

Os alunos dedicam parte do tempo à produção da capa para a coletânea de atividades feitas durante o bimestre, material que costuma ser levado à reunião de pais a fim de conversarem com a professora sobre a aprendizagem de seus filhos. Por ser uma atividade mais livre, caminhamos pela sala, vamos até as carteiras de vários alunos, dialogamos e vemos as atividades realizadas de março a final de abril.

Entramos na sala de Lia, e os alunos estão envolvidos com um jogo de palavras cruzadas desenhado em folha mimeografada, retirado de um livro denominado "Abecedário dos Bichos" $^{\prime 56}$. A figura consta de uma única coluna vertical onde está inscrita a palavra "harpia",

\footnotetext{
56 Lia informa que este livro é adotado há alguns anos. Através dele é norteado o ensino de leitura e escrita de todo 0 ano letivo para as turmas de $1^{a}$ série desta escola. É um manual em que constam letras do alfabeto, cada
} 
uma ave de rapina conhecida popularmente como 'gavião-real'. Na horizontal, pequenos quadrados indicam o local para transcrição das palavras do exercício - uma letra para cada quadrado. Ao lado, há seis desenhos e, sob eles, as palavras: helicóptero, holofote, hipopótamo, harpa, herói e hóstia.

As crianças parecem conhecer bem como proceder. Lia os orienta somente para que atentem à contagem de número de letras de cada palavra a fim de identificarem onde as palavras devem ser escritas. A docente finaliza as explicações mencionando que, ao final, poderão colorir os desenhos, e que a atividade será incluída no material individual, cuja capa terminarão ainda neste dia, após o intervalo de recreio.

Não nos sentimos à vontade para caminhar entre as carteiras, pois a própria professora permanece à sua mesa. Acompanhamos produções dos que estão sentados mais proximamente.

Após vinte minutos, algumas crianças se dirigem a Lia para lhe mostrar seus trabalhos. Em seguida, ela indaga se a correção do exercício pode ser iniciada. Não havendo vozes em contrário, completa a figura do jogo que está desenhada no quadro-negro. Com as crianças, conta o número de letras de cada palavra, escrevendo o resultado ao lado para, depois, contar os números de quadrados na figura.

Feita a correspondência, vai perguntando o que deve ser colocado em cada linha, até ficar concluída a palavra-cruzada, conforme representado abaixo:

\author{
HELICÓPTERO - 11 LETRAS \\ HOLOFOTE - 8 LETRAS \\ HIPOPÓTAMO - 10 LETRAS \\ HARPA - 5 LETRAS \\ HERÓI - 5 LETRAS \\ HÓSTIA - 6 LETRAS
}

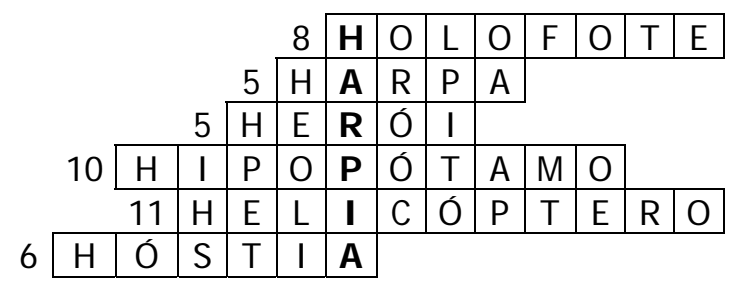

\section{Figura 5.1 - Representação de atividade observada na classe de Lia}

Os alunos acompanham o que a professora faz. Aqueles que se vêem capazes de fornecer as respostas adequadas se expõem oralmente. Uma parte da sala permanece em silêncio, alguns se entretêm com a tarefa de pintar os desenhos, outros completam sua figura, copiando do quadro-negro. Após corrigir o exercício, a professora recomenda que todos verifiquem se acertaram.

Terminada a correção, Lia solicita a atenção da classe para uma frase que está nos 
quadros de aviso de uma parede da sala:

Olhem lá, no 'cotovia'... A gente tem o desenho da cotovia. Lembram que a gente fez palavra-cruzada da cotovia e escolheu a frase que tá escrita lá? Agora, vamos fazer parecido. Vamos ver? Com harpia, não. Uma frase com hipopótamo... Quem é que pode me dar uma frase?

Os alunos se alvoroçam, desejosos de dar sua contribuição. A professora organiza, pedindo que levantem a mão e aguardem serem chamados. Um deles diz: "O hipopótamo toma banho...". Lia anota a frase no quadro-negro. Outros completam: "Toma água", "se sujou", "me sujou". Registrando as frases, a professora sugere à classe que sejam copiadas nos cadernos.

Nos últimos minutos dessa observação, Lia entrega folhas contendo os desenhos inacabados das capas da coleção de atividades do bimestre a fim de que sejam finalizados. As crianças saem de suas carteiras livremente, alguns ficam ao lado da própria mesa, desenhando em pé. Permanecemos em sala até o horário do recreio.

A segunda visita à classe de Bel ocorre durante uma atividade de Língua Portuguesa. Há, sobre as mesas dos alunos, tiras de papel contendo versos de um poema. A tarefa consiste em organizar as tiras na seqüência original do poema para, depois, colar no caderno.

Há alunos em pé, ao lado de sua mesa; dois ou três ao redor da professora; outros, sentados; todos compenetrados na atividade. Bel circula entre as carteiras e, às vezes, responde e dirige a sua atenção para os que insistem em segui-la pela classe; noutras, pede que permaneçam em seus lugares.

Devido a essa configuração do cenário de aprendizagem, marcada pelo alto envolvimento da classe, nossa entrada é quase imperceptível. A professora é avisada de nossa presença por algumas meninas próximas à porta da sala. Bel nos informa o que está ocorrendo e nos deixa à vontade para acompanhar o que os alunos fazem.

Tempos depois, quase toda a turma está terminando a colagem do poema nos cadernos. Alguns alunos, tendo terminado e notando que estamos em pé à frente de um grande painel que cobre a parede do fundo da sala, vêm ao nosso encontro. Uma menina comenta: "É a música da 'casa'. Quer que eu canto?". Mal ela termina a frase, um coro de três crianças iniciam: "Era uma casa muito engraçada, não tinha teto, não tinha nada...".

O canto faz os demais alunos dirigirem a atenção para o pequeno grupo, ao que solicitamos que deixem para cantar ao final da aula e, em contrapartida, expliquem o painel. As crianças falam animadamente como se deu a construção coletiva do cartaz, simbolizando o poema; como conheceram esse e outros poemas de Vinícius de Moraes, poeta que passou a figurar entre os prediletos da turma; a quais partes do cartaz correspondem desenhos e 
enfeites feitos por eles ou por colegas mais chegados, retratando não apenas conteúdos aprendidos, mas prazer e orgulho por sua produção.

Finalizada a atividade, Bel solicita que todos colaborem na limpeza. Somente depois disso, assim como Lia, a professora entrega os desenhos inacabados das capas de coleções de atividades que os alunos devem finalizar.

Permanecemos durante mais algum tempo na sala. Muitos alunos nos mostram seus desenhos e atividades feitas durante 0 bimestre. Pedimos explicações, indagamos sobre 0 que têm aprendido, que assuntos foram mais apreciados e atividades mais difíceis, se têm hábito de fazer outras coisas juntos, etc.

Segundo as crianças, há ocasiões em que, à semelhança do painel, toda a turma é envolvida, e outras em que a atividade ocorre em dupla. Esse dado explicita uma forma de organização do cenário de aprendizagem bastante semelhante ao modo como previmos a inserção de atividades lúdicas em classe.

\subsection{3 - O Percurso Formativo e o Desenvolvimento Profissional Docente}

Cada fase do percurso de formação representa, em diferentes níveis, ampliação de saberes da prática ludo-educativa. Os quatro temas dos encontros do grupo formativo (recursos e procedimentos de jogo; caracterização de jogo educativo; conceituação de ludoeducação; jogo - atuação discente) e os quatro relativos à execução de jogo com os alunos (organização do cenário de aprendizagem; mediação pedagógica; interação social; avaliação da aprendizagem) constituem eixos centrais para discutirmos, compararmos e interpretarmos como a ludo-educação é experienciada, passando a tomar parte do modo de pensar e atuar das duas professoras.

O desenvolvimento é um processo demorado e não linear, por isso os diversos componentes de reflexão e ação ludo-educativas não se apresentam integrados hierárquica e ordenadamente tanto para Lia quanto para Bel. Uns entram em cena logo nas primeiras experiências; outros tornam-se presentes somente ao final do projeto ou não chegam a ser implementados. Há, portanto, muitas variações no percurso de cada docente, bem como na comparação entre elas.

A fim de acompanharmos essas mudanças, manteremos a seqüência cronológica do projeto, por fases, destacando em cada momento os aspectos característicos de prática ludoeducativa presentes:

- nos dois casos estudados;

- num dos casos;

- somente no plano discursivo ou no da prática, nos dois ou apenas num dos casos. 
A opção pela cronologia é mais adequada que a discussão pelos oito temas, o que demandaria ir e vir a cada um dos momentos do percurso de formação. No entanto, estruturar a análise pela seqüência das fases não impede que cada bloco tenha alguns elementos de comparação entre diferentes experiências lúdicas e contenha dados complementares, pelas entrevistas.

Lembremos que, na primeira fase, não há participação direta dos alunos. Por ser um momento inicial e não comportar as mudanças mais significativas do percurso de desenvolvimento das professoras, não incluiremos o exame específico dessa etapa.

Com relação à segunda fase, enfocaremos sobretudo a experiência com o jogo de História do Teatro, excluindo as demais vivências lúdicas.

Quanto aos jogos de Percurso (terceira fase) e Tapão na Matemática (quarta fase), uma parte significativa dos dados será tematizada e discutida.

\subsubsection{1 - Análise do J ogo de História do Teatro - 2a fase do projeto formativo}

\section{a) Reunião de planejamento}

Ao iniciar o décimo encontro, a formadora explica que a experiência de uma mesma atividade, envolvendo todas as participantes, contribui com os propósitos de pesquisa, oferecendo também condições de melhor avaliar a formação durante seu curso de desenvolvimento. Observando que nenhum dos jogos escolhidos pelas professoras na reunião anterior incluíram o faz-de-conta (jogo sem predomínio de regras), Alê o sugere a fim de oportunizar a experiência de uma atividade voltada à expressão do imaginário. Com esse intuito, a proposta do jogo de História do Teatro $^{57}$ é apresentada:

A idéia é de um faz-de-conta, como os que elas (as crianças) costumam fazer em casa... é como se fosse uma viagem por momentos diferentes da história do teatro. Passar pela Grécia Antiga ou fingir que é um Samurai... até chegar no teatro contemporâneo, numa cena do dia-a-dia. Cada grupinho faz uma cena. A Tânia preparou prá gente umas idéias para nortear o planejamento. Fez oito cenas pra criançada brincar de estar num determinado tempo dessa história, que será indicado pelo sorteio das fichas... As fichas vão ter informações pra orientar cada cena. A gente deixa à disposição alguns objetos - umas fantasias e máscaras - pra compor esse imaginário da criança. Eles criam as ceninhas de improviso. 0

\footnotetext{
${ }^{57}$ A estrutura final do jogo foi estabelecida nessa reunião, tendo-se a participação das professoras na tomada de algumas decisões sobre alterações e acréscimos. Seu formato original foi elaborado pela auxiliar de pesquisa Tânia Amares Bueno, mediante orientações da formadora para que envolvesse situações imaginárias e se articulasse com objetivos de ensino do Ciclo I. O jogo se reporta à história da humanidade, pela seleção de alguns dos momentos mais célebres do teatro, desde os tempos mais remotos até a atualidade, através de oito cenas: origens na Pré-história; rituais da Antiguidade; teatro grego; comédia dell'Arte; Idade Média; Renascimento; teatro oriental e atual.
} 
objetivo é comparar épocas, perceber o encadeamento histórico... através de um tema diferente dos que estão acostumadas a ter na escola. Por ser a primeira vez que vão experimentar esse tipo de jogo, poderia ser uma atividade mais (voltada) pro imaginário.

A proposta é recebida com certa resistência. As professoras se opõem, especialmente por julgarem como uma verdadeira encenação teatral, exigindo domínio de palco, memorização de texto, expressão corporal artística, além de informações sobre os temas envolvidos em cada cena. A maior parte dos questionamentos indica que, desconhecendo o jogo, apostam na necessidade de haver preparo sobre os assuntos tratados, no caso, os de história real da arte cênica.

Esclarecendo melhor a proposta, Alê exemplifica utilizando um dos textos previstos para as fichas:

Essa (ficha) é do "teatro primitivo". Esse é o título. Alí, vem: "dentro de uma caverna, um grupo de pessoas está reunido em volta de uma fogueira. Chega um outro homem assustado, querendo avisar sobre um leão lá fora. Mas tem um detalhe importante: ainda não sabe falar! Como é que vai avisar seus amigos? Entra o leão. E, agora? O que será que vai acontecer? Os homens da caverna vão conseguir fugir? Será que vão acabar com o leão?". Eu acho que valeria a pena deixar mais curtinho, só com idéias bem gerais. Mas serve como exemplo... Os alunos vão ler e improvisar a cena.

Lia ressalta que os alunos não estão preparados para representar, pressupondo que a brincadeira demanda um cabedal de conhecimentos e habilidades específicos, destituídos de sentido pelo que se apresenta no programa curricular de $1 \underline{\text { ạ }}$ série.

Mesmo com as explicações da formadora, o grupo reluta em considerar a proposta viável. Lia declara:

Mas será que eles sabem o que é teatro? Têm vivência disso? E se ficasse em conto de fadas, não seria melhor? Eu estou achando impossivel as crianças que a gente tem aqui conseguirem. Até pra entender a proposta... Eles não estão acostumados.

Retomando a palavra, a formadora dá novas pistas da caracterização da proposta:

é que os contos são atemporais... Eu acho mais difícil propor uma vinculação mais direta com ensino pelo conto. Porque o que é central nesse jogo é relacionar imaginação com história. Tá relacionado com orientação temporal... Associar o imaginário com a construção de conhecimento faz parte do aprendizado, né? Por exemplo, a gente não precisa ter visto as caravelas chegando na costa brasileira prá poder imaginar, e passa a compor idéias sobre a vinda dos portugueses na era dos Descobrimentos. Dá pra dizer que esse conhecimento se formou porque a gente é capaz de imaginar eventos passados a partir de descrição... leitura, das coisas que se aprende na 
escola.

A partir desses comentários, Bel também invoca a necessidade dos educandos terem conhecimento prévio sobre a história do teatro, que valide um faz-de-conta alusivo a personagens famosos, como Romeu e Julieta, ou ao mitológico Baco ${ }^{58}$. Em sua análise, pondera que:

Eu achei a idéia interessante, por essa ligação com a História. É bem diferente! Mas... Sabe? São de escola municipal... Romeu e Julieta pra eles é goiabada com queijo. Isso se sabem o que é goiabada! Como vão encenar uma peça de Shakespeare sem nem saber quem ele é? Teriam que conhecer o assunto antes de fazer o teatrinho!!!

Nas análises produzidas pelas professoras, habilidades e conhecimentos prévios ao próprio jogo são indispensáveis, determinando novas explicações da formadora. Aos poucos, os discursos passam a se alinhar. Mediante detalhamento da significação do tema, isto é, pela ênfase na relação entre desenvolvimento do imaginário infantil e apropriação de conceitos escolares, as professoras passam a se envolver com a proposta e considerá-la pertinente. Destacam, especialmente, dois aspectos: a experiência comum de uma mesma atividade e a inserção de uma proposta não competitiva.

$\mathrm{Na}$ continuidade da discussão, uma série de medidas são estabelecidas a fim de se efetuar o jogo. Apesar disso, o desconforto das professoras com relação à proposta novamente se manifesta quando a experiência é concretizada.

\section{b) Realização do jogo em sala de aula}

Quando a atividade é executada, as professoras demonstram insegurança, delegando à formadora a incumbência de interagir diretamente com os alunos, tanto nos preparativos e instruções iniciais quanto durante o jogo. Buscando trazê-las à cena, a todo instante Alê solicita diferentes 'tarefas': auxiliar na organização da sala para que os grupos se formem; colaborar na exemplificação de um determinado aspecto do jogo; encarregar-se do acompanhamento da leitura das fichas onde estão registradas as informações de cada cena (grupo a grupo). A formadora propõe à professora se transformar num personagem, o Senhor do Tempo, responsabilizando-a por conduzir a viagem entre as diferentes épocas do teatro, cujas incumbências são: o sorteio de cada grupo para apresentar uma das cenas e para determinar o intervalo de tempo que finalizará uma encenação para dar-se início à

\footnotetext{
58 Sobre a cena relativa ao teatro grego, na ficha, o mito é recriado: "Deitado numa nuvem, Baco come tanta uva que fica com dor de barriga. Bravo, ele resmunga: 'Chega de uvas! Não quero mais!'. Imediatamente, do outro lado, na Terra, os homens vêem suas plantações murcharem... Precisam pedir ao deus Baco que volte a proteger a plantação... Mas como???"
} 
próxima, garantindo que todos sejam, num momento, atores e, noutro, espectadores.

Enquanto as crianças brincam com lendas e mitos, Bel restringe sua ação ao sorteio e controle de tempo para cada grupo. Ela praticamente não se movimenta em classe. Mantémse pouco à vontade, enquanto seus alunos se divertem com figurinos e personagens, enfeitando-se e pondo-se ao centro da sala para encenar. A forma como se estabelece 0 cenário ludo-educativo libera cada grupo para suplantar as informações contidas nas fichas, onde constam as idéias gerais acerca de cada cena. Lia se comporta de maneira semelhante.

Ambas seguem à risca as orientações da formadora. Procuram assegurar que os alunos se mantenham fiéis ao que fora proposto no encontro de planejamento e ao conteúdo das fichas, mesmo que isso se contraponha às necessidades educativas e refreie os interesses das crianças que, ao contrário, assumem a brincadeira com vivacidade, o que produz um efeito muito distinto das expectativas elencadas na reunião.

\section{c) Reunião pós-atividade}

No primeiro encontro após a realização do História do Teatro, as professoras utilizam grande parte da conversa enumerando exemplos e comparando as encenações. Por solicitação das professoras, episódios das filmagens de sala de aula serão utilizados como material para dar continuidade ao processo formativo. A própria reunião se produz num clima lúdico.

No encontro seguinte, a formadora propõe ao grupo assistir não apenas a trechos do jogo realizado com os alunos, mas também a algumas cenas previamente selecionadas que remontam a diferentes momentos do processo formativo, desde seu início. As professoras apóiam a medida, considerando que dessa forma também poderão 'se ver' nas filmagens.

Em função desta estratégia formativa, ao grande interesse em torno do jogo de História do Teatro adicionam-se outros, conforme as professoras assistem aos vídeos. Para sistematizar a discussão, Alê propõe que, a cada episódio (de aproximadamente 12 minutos), as professoras teçam comentários, focalizando o clima interativo, os mecanismos e verbalizações de solicitação de apoio e os de colaboração, eventuais situações em que se presencia aprendizagem em curso, exemplos de resolução de problemas e de criação.

Objetivando garantir que a reunião seja conduzida pela voz das docentes, a formadora faz incursões ocasionais para que detalhem melhor um ou outro assunto específico.

$\mathrm{Na}$ espontaneidade com que as professoras dialogam, os temas se intercruzam. No caso da confecção de jogos, surgem divergências. Algumas das professoras apontam que a durabilidade do material e a falta de tempo são aspectos que justificam a impossibilidade de os alunos prepararem o jogo. Outras enfatizam que o preparo de objetos lúdicos é possível. 
Lia é uma das que acreditam na viabilidade, observando que:

daria pra fazer com sucata... Tem umas tampinhas de garrafa, uns papelões jogados aí (no depósito da escola)... Dá pra juntar essas coisas e fazer uns jogos. Eu tenho em casa, do meu filho, um que vem uns seis jogos juntos. Tem o tabuleiro e seis jogos. $O$ tabuleiro é um papelão duro. (Tomando-o como modelo) a gente pega umas caixas de sapato e umas tampinhas... não é difícil fazer. O tabuleiro é quase universal... tabuleiro com fichas e pecinhas feitas de tampinhas. E pronto! Fica com um tabuleiro pra vários jogos... Eu não sei, não... Na minha época, a gente tinha tanto jogo! Fazia parte da vida da gente se reunir com a turma pra jogar. Em dia de chuva era isso: jogo de dia de chuva. Ficava horas com a turma... Eu gosto de trazer essas coisas pros alunos. No ano passado, ... eu trouxe jogo da velha... Porque é gostoso, você vê a alegria deles quando você deixa um tempo pra essas atividades que, de certa forma, também são de aprendizagem.

O fragmento ilustra que, embora favorável à criação de jogo, as observações de Lia esgotam-se na concretude de exemplos, propondo soluções genéricas - "tabuleiro com fichas e pecinhas feitas de tampinhas. E pronto!" - relativas a concepções que dificultam alcançar valores e princípios ludo-educativos.

As análises de Lia mostram-se precárias, pois insinuam que a confecção cabe ao educador, sem a participação dos alunos. Nesse sentido, a criação de objetos lúdicos é desprovida de funcionalidade educativa.

Quanto ao jogo de História do Teatro, o grupo se atém à apreciação, enaltecendo a criatividade de seus alunos.

Ao fim do projeto, um excerto do último encontro demarca uma substancial diferença entre o clima tenso da reunião de planejamento e a superficialidade das apreciações dos vídeos, com uma interpretação seguramente mais positiva da vivência com o jogo:

(Bel) É, na minha sala, essas interferências (interação entre pares) começaram meio instintivas, mas o produto acabou sendo muito bacana! Teve uma das cenas, que era do Teatro do Oriente... com os samurais e as princesas. Na ficha que eles leram, não tinha nada de gente que morria. Só explicava que, no Japão, os samurais são os defensores da família do imperador. Mas na hora do teatrinho, o grupo montou uma briga entre dois samurais, cada um defendia a honra de uma princesa... uma coisa mais ou menos assim... e o samurai que perdeu (a luta) ficou deitado no chão com as princesas chorando ao redor dele. Até o outro samurai fez que chorou junto!! Nessa hora, eu tava perto do Reynaldo ${ }^{59}$ (aluno de outro grupo) e ouvi ele cantando a marcha fúnebre. E a Alê percebeu a situação, e fez um sinal de positivo pra ele. Na mesma hora, os coleguinhas do Reynaldo - que eram do mesmo grupo - engrossaram o coro.

\footnotetext{
${ }^{59}$ Os nomes das crianças são fictícios, tal como os das professoras.
} 
Começou aquela marcha fúnebre no grupinho. Depois, a coisa foi crescendo, e a sala toda tava cantando a marcha fúnebre. Com todo esse fundo sonoro... imagina a cena!!! A sala toda: tan... tan... tan... ran... $\tan . .$. tan-ran, tan...ran... tan-ran (imitando os alunos, no mesmo tom austero que fizeram) ${ }^{60}$. A turminha que estava representando... eles não perceberam no começo. Só depois de um tempo perceberam que tinham que fazer um enterro prá combinar com a cantoria! Ficou igual diretor de teatro. Eles foram dirigidos pelos outros grupos. Ficaram girando igual procissão ao redor do samurai, que continuou no chão paradinho, com as mãos cruzadas em cima da barriga. Vocês precisavam ver... Foi histórico!

A análise de Bel não implica simples apreciação. Ao se dar conta de que as 'interferências começaram meio instintivas' e que 'eles foram dirigidos pelos outros grupos' a professora refere-se ao comportamento dos alunos. Modula suas observações pelo que ocorre na interação aluno/aluno.

Contudo, seja na explanação de Bel ou de suas colegas, novas significações sobre a interação entre educandos se anunciam sem que o grupo se proponha a debatê-las.

As professoras poderiam levantar questões e hipóteses sobre o quê? De acordo com a ludo-educação, implica o exame de como garantir, estimular e avaliar as interações entre pares a fim de que nelas também se constitua o processo de ensino-aprendizagem. Interagindo, as crianças se autorizam a definir a direção da atividade, auto-avaliam suas habilidades, comparando-as com as dos parceiros, criam problemas e negociam soluções.

Esses elementos também orientam o educador a interagir, assegurando equilíbrio entre promover a autonomia discente e ajustar o encaminhamento da atividade às necessidades educativas. Ao educador, é tão importante reconhecer e valorizar os momentos em que os alunos são os protagonistas quanto criar condições para que isso ocorra - não ocasional, mas sistematicamente - no decurso do processo de ensino-aprendizagem.

Portanto, são questões para as quais não se encontra solução única e simples, uma das razões para que o tema da interação tenha se mantido na superfície ao longo de todo o projeto para as duas professoras. Até a última experiência de jogo - tanto na classe de Lia quanto na de Bel - prepondera a comunicação definida pela centralidade da figura docente, especialmente para controlar o comportamento e configurar as regras de jogo. Não há como estabelecer limites entre a regência do educador e a autonomia dos educandos, mas é certo que a eles se associam transformações bastante profundas na própria atuação pedagógica a fim de criar condições e estimular os alunos para que tenham voz ativa em sala de aula, assim como as professoras precisam ter assegurado o direito de decidir sobre fatores

60 o trecho, popularmente conhecido, refere-se ao início do terceiro movimento da Sonata No 2, Opus 35, de Chopin, tornado famoso mundialmente com o codinome de "Marcha Fúnebre". 
determinantes do exercício da profissão.

A inclinação por considerar difícil a concretização do ensino lúdico é retomada nas entrevistas após o término do projeto. Lia indica ser necessário ter certas condições para a prática ludo-educativa se consolidar. Para ela, o planejamento é essencial; além dele,

condições materiais e, por fim, o ideal seria ter sempre um auxiliar em sala, além de ter espaço adequado, porque nossas salas são muito pequenas para a movimentação que eles precisam e, claro, ter menor número de alunos por turma. (entrevista final)

$\mathrm{Na}$ entrevista de feedback, Lia retoma o tema das classes numerosas - cuja resolução envolve as inter-relações da escola com outros níveis do sistema educativo - como um dos maiores obstáculos a serem transpostos para a ludo-educação integrar o processo de ensinoaprendizagem.

$\mathrm{Na}$ entrevista final, a professora Bel destaca que a classe numerosa é um grande obstáculo para se estabelecer uma rotina com propostas lúdicas de ensino. No entanto, pondera que, em função disso, práticas lúdicas deveriam compor um "planejamento lúdico para todo o Ciclo", ressaltando a importância da interação entre os profissionais como meio de "reunir forças... ficar mais integrado".

Ambas reconhecem o mesmo problema, apesar da divergência. Esse fato tem respaldo no percurso formativo das professoras. Conforme veremos mais adiante, a experiência com outros jogos assinala modos de atuar contrastantes para contornar os obstáculos à inserção de mediadores lúdicos de ensino.

Nas duas últimas fases, durante as outras atividades experienciadas com os alunos, Bel interage com cada grupo, interroga, incentiva e fornece pistas. Ora propõe alternativas para as crianças lidarem com um problema, ora insere novos desafios (cuidando para que sejam compatíveis com o encaminhamento da atividade lúdica e dos objetivos educativos). Contudo, permanecem excluídos mecanismos que possibilitem compartilhar com os alunos a caracterização do jogo ou que promovam auto-avaliação discente.

De modo eloqüente ao que foi possível experienciar pelo projeto, na avaliação da prática ludo-educativa em geral, conferem exclusivamente ao educador a definição e caracterização do jogo, sem participação dos alunos na tomada de decisão sobre o que será feito e como deverão atuar, tal como conceitua Lia na entrevista final:

O jogo só funciona se, primeiro, na instrução, deixar as regras bem claras pros alunos. Depois, na hora de fazerem o jogo e de jogarem, o trabalho em grupo for estruturado pelo professor, numa ordem lógica, em função do que cada aluno é capaz de fazer e onde tem mais dificuldade. Os materiais... a preferência deve ser por aqueles 
que fazem parte do dia-a-dia da criança, que ela tenha um conhecimento prévio... Também é bom lembrar que na avaliação dos resultados do jogo... conversar com os alunos para levantar o que foi positivo e o que foi negativo.

Embora a compreensão de aspectos que definem a ludo-educação envolva contradições, as professoras valorizam o jogo como mediador de ensino. Lia enumera razões que a fazem pensar nas possibilidades de tomar a atividade lúdica como suporte de sua prática, futuramente. Imagina que, através de brincadeiras e jogos voltados à aprendizagem, poderá promover não apenas o ensino de conteúdos, mas permitir às crianças...

expressarem seus sentimentos, exercitarem sua imaginação... (0 jogo) auxilia na melhoria do comportamento dos alunos... E, pelo que a gente fez, dá bem pra ter à disposição os materiais lúdicos (confeccionados)... a gente tem nas mãos uma forma de manter os alunos interessados. (entrevista de feedback)

Numa abordagem semelhante, Bel postula que a atividade lúdica

é um jeito de exercitar a imaginação das crianças. Elas se sentem mais à vontade para se expressar, junto com o desenvolvimento da motricidade... Quando a sala está toda envolvida com as brincadeiras, praticamente não existe problema de comportamento, está todo mundo envolvido... (entrevista final)

Assim definido, o jogo prescinde da ação do educador,

... estabelecendo as regras. E é preferivel manter o arranjo de trabalhar em pequenos grupos, mas sempre fazendo um trabalho prévio de planejamento... (Quanto aos materiais) no caso de precisar ter, serem confeccionados pelas crianças, serem de jogos que eles conhecem do dia-a-dia... mostrar aos alunos que o jogo não é só uma brincadeira, mas uma maneira de aprender. É o professor que precisa ter clareza dos jogos mais adequados para um conteúdo proposto. No final, é bom deixar um tempo reservado para avaliação do jogo, levando os alunos a pensarem sobre o que aconteceu. (entrevista de feedback)

As professoras não formulam justificativas para a inexistência da negociação com os alunos embora reconheçam sua importância.

Porém, ao ser entrevistada meses depois do término do projeto, a professora Bel se distingue de Lia num importante aspecto. Para Bel, é preciso determinar um momento específico para que o corpo discente tenha voz ativa em seu processo de aprendizagem, reportando-se à etapa de avaliação discente do jogo. Postula ser válido abrir espaço para o diálogo simétrico a fim de que as apreciações da atividade desencadeiem outras modalidades lúdicas a se experienciar. Apesar de Bel defender essa atitude na entrevista, não foi viável estabelecê-la em sua prática; pelo menos, não no intervalo de tempo 
transcorrido entre início e término da proposta de formação.

O material específico da segunda fase - de planejamento, realização e avaliação do jogo de História do Teatro - mostra que as professoras não escondem a sensação de insegurança, desconfiança e receio pelo fracasso da inserção de jogo em sala de aula. $\mathrm{Na}$ interação com os alunos, ficam pouco à vontade, à espera da ação da formadora, seja para as instruções iniciais ou na mediação da atividade durante sua execução. Ao avaliarem o jogo, permanecem na apreciação não reflexiva. Surpreendem-se com a dinâmica interativa das crianças, acreditando que a prática ludo-educativa seja viável.

$\mathrm{Na}$ quarta fase e nas entrevistas, podemos notar ressignificações do que vivenciaram com o jogo de História do Teatro. Tanto Bel quanto Lia frisam a importância da interação aluno/aluno proporcionada pela atividade, mas não sabem como promovê-la.

Dois aspectos interferem na parcialidade do julgamento das professoras. Um deles refere-se à crença de que o jogo possibilita naturalmente a interação, avaliando que é suficiente deixar as crianças brincando e que é desnecessária a intervenção pedagógica para ampliar e aprofundar a qualidade dessas interações. Portanto, apesar de Bel observar que, no jogo de História do Teatro, os alunos que encenavam foram 'dirigidos' pelos demais, a professora não examina de que maneira as 'interferências instintivas' entre os alunos foram estimuladas.

O outro aspecto diz respeito à forte tendência em considerar que caiba exclusivamente ao educador definir o jogo, tal como as demais atividades pedagógicas. Assim, interações que elevem a negociação, estabelecendo níveis mais complexos da autonomia discente, são descartadas. Ter de lidar com classes numerosas é a principal justificativa das professoras para a inviabilidade de assumir uma prática pedagógica em que compartilhem com as crianças a definição de regras e procedimentos que estruturam o jogo.

\subsubsection{2 - Análise do J ogo de Percurso - 3ạa Fase do Projeto Formativo}

\section{a) Reunião de planejamento}

A terceira fase é demarcada por mudanças importantes. Na primeira das reuniões, é Lia quem anuncia uma visão distinta em relação a materiais que deixaram de ser descartáveis e se tornaram geradores de idéias para confecção de objetos lúdicos:

em casa, agora até o meu marido pergunta pra mim se um lixo que ele vai jogar fora... se eu quero guardar pra fazer brinquedo. Dia desses, a gente fez um dominó de caixas de fósforo! ... Eu vou virar sucateira igual você (sorrindo, dirigindo-se à formadora).

Ou, ainda, no intuito de investir em novas atividades lúdicas, solicita aos alunos 
coletarem os objetos que seriam destinados à construção de um jogo de boliche:

eu estou juntando com os alunos as garrafas de leite. Sabe? Aquela garrafa bonitona que é mais pesada do que litro de refrigerante. Depois os alunos vão enfeitar e fazer o jogo na classe.

A professora demonstra uma percepção nova em relação a recursos ludo-educativos. Vale ressaltarmos que, embora disposta a seguir adiante autonomamente, com a inserção de jogos no ensino, Lia não realiza a experiência do jogo de boliche.

No segundo encontro, as professoras posicionam-se de maneira bastante independente, em comparação às fases anteriores. Estabelecem dois eixos para a continuidade do projeto: um deles é a planificação de um jogo dirigido à área de Língua Portuguesa, o outro, ao ensino de Matemática. O papel da formadora limita-se a retomar os jogos vistos ou experienciados, destacando em cada qual características que auxiliem a escolha, pelas professoras, dos mais adequados às condições estruturais da escola e séries/turmas (meios de obtenção e confecção dos objetos lúdicos) e atendam aos objetivos educativos.

$\mathrm{Na}$ reunião seguinte, o jogo de Percurso é planejado objetivando contribuir para o desenvolvimento das competências de leitura e escrita, segundo o conteúdo de Língua Portuguesa das diferentes séries. Da maneira como é caracterizado, a escrita ocorre sobretudo na elaboração de 'cartelas-desafio' que, na execução do jogo, serão lidas para orientar a ação dos jogadores.

Nesse período, os alunos de Lia sabem ler palavras, mas não têm domínio da escrita. Tal condição é um obstáculo ao preparo das cartelas de jogo e, ao mesmo tempo, aspecto essencial em que a atividade deve incidir a fim de que contribua para a aprendizagem.

$\mathrm{Na}$ forma em que é planejado, o jogo deve promover a escrita através do preparo de seus objetos lúdicos. A atividade é composta pelos seguintes recursos: tabuleiro com percurso; peões; dados e cartelas com desafios, todos confeccionados pelos alunos.

Tabuleiro e cartelas articulam-se para associar o conteúdo de ensino à ludicidade do jogo. Cada jogador, na sua vez, joga o dado; o número tirado corresponde à quantia de casas que seu peão caminha no percurso. Se o peão pára numa casa em que está desenhado um obstáculo, o jogador tem que retirar uma cartela do monte. Ele lê o texto da pergunta, responde oralmente e, conforme sua resposta, pode ganhar o direito de andar mais casas, jogar o dado mais uma vez ou retroceder no percurso, ficar sem uma jogada, entre outras possibilidades.

Dessa forma, a escrita tem a função de dificultar o jogo, torná-lo desafiador, pois explicita qual conseqüência corresponderá a aceitação de sua resposta pelos demais integrantes do grupo. Instigar os alunos à elaboração dos desafios equivale a promover que 
discutam, decidam e criem soluções próprias a fim de 'escrever' os textos.

No formato final, as cartelas são compostas de: desafio (uma pergunta direcionada a conteúdos de Língua Portuguesa) e orientação ao jogador tanto para o caso de acerto como para o caso de erro da resposta.

As professoras também prevêem variações na estrutura do texto da cartela, conforme 0 nível de aprendizagem de cada série/turma. Por exemplo: para alunos de $3^{\text {a }}$ série, é esperado que sejam capazes de formular as perguntas na forma de frase(s) completa(s).

Por sua vez, Lia acredita que a escrita do texto é completamente inviável, explicando que, da sua turma de $1^{\text {a }}$ série, somente seis alunos seriam 'alfabéticos'. Seguindo a mesma terminologia, acrescenta que há alunos em outros níveis - uma maioria 'silábico-alfabética' e alguns com escrita 'silábica'61. Apreensiva, observa que

tem alunos que não sabem escrever. Alguns já escrevem palavras, mas não fazem frases. E ainda tem os silábicos, que ou juntam as palavras ou nem escrevem direito... Como eles vão fazer? Que colocações vou colocar? Não consigo... Não consigo pensar muitas coisas pra colocar nas cartelas. Está meio difícil de captar a coisa.

Para os alunos de Lia, a confecção das cartelas do Percurso e seu uso durante o jogo deveriam enfocar a alfabetização. Mas como a elaboração das cartelas poderia transpor a dificuldade com a escrita? À primeira vista, Lia pondera que "está meio difícil de captar a coisa".

Em função do comentário de Lia, o grupo se mobiliza. Ao contrário dos encontros anteriores, as demais professoras intervêm, visando lhe fornecer indicações. Bel lembra que:

(os alunos podem combinar) o desenho de um objeto com sinais de pontuação. Faz o desenho de um sapato e deixa como regra que isso serve pra indicar que tem que escrever a palavra ou, pelo menos, dizer o nome da primeira letra, coisa desse tipo...

(Alê) Não entendi bem onde fica o sinal de pontuação...

(Bel) Pensei por alto... Põe o sapato e uma interrogação pra... ser contagem de silabas. Se for uma exclamação, é pra escrever a palavra toda. Dois pontos... escreve outra palavra que termina com a mesma sílaba...

(Alê) ...Hum, tá parecendo uma adivinha. Uma advinda pontuada!!! O sinal de pontuação é uma sub-regra, né? Como se fosse "Macaco Simão". A exclamação mandou fazer ' $x$ '...

(Lia) Como vão saber? Eu posso colocar na lousa essa legenda?

${ }^{61}$ Não nos cabe julgar quão válido e correto é este julgamento de Lia, pois isso determinaria investigar vários aspectos de sua prática para que viéssemos a conhecer de que maneira a teoria de Emilia Ferreiro repercute na constituição de sua profissionalidade, sendo preciso uma pesquisa que comportasse esse objetivo. Mais importante para nosso trabalho formativo é ter em conta que, iniciando o mês de agosto, a maioria dos alunos lê, escreve algumas palavras isoladas e copia frases, mas não tem o domínio da escrita. 
(Bel) Achei (que é) por aí mesmo...

Outra professora, lembrando que Lia utiliza animais como tema para a alfabetização, sugere: "Eles fazem o desenho, sei lá, do macaco por exemplo. E embaixo, como se fosse Forca, coloca seis traços para escrever a palavra", e complementa:

além do desenho, a pergunta vem escrita embaixo... do jeito deles mesmo. Eu pensei... como a Bel falou, que dá pra criar uns modelos de frases na lousa pra eles escolherem pra acrescentar na cartela. Pode fazer uma espécie de legenda na lousa pra eles copiarem. Eu tava pensando... os desenhos ficam no lugar do texto escrito, certo? E a última parte (a de conseqüência para o jogador, mediante acerto ou erro de resposta), põe um texto padrão que eles copiam da lousa, junto com as opções de legenda: volta duas (casas), anda duas, fica sem jogar, outro pode responder...

(Alê) Tá pensando numa associação entre legenda de pergunta com legenda de orientação? Ou somente uma listinha para cada um, deixando pros alunos escolherem?

(Val) Na associação... que é que você acha, Lia?

(Lia) Pode ser... fica mais organizado.

(Bel) Eu acho que poderia ter o desenho do animal para eles escreverem sobre o animal, as coisas que sabem do animal... Ou então soletrar... Pra $3^{a}$ (série), acho que o desenho pode incrementar para adivinha de poesia. (Eles) podem colocar: escreva um sinônimo num papel à parte, forme uma rima... distinguir os substantivos, os verbos...

(Alê) Mas aí, é com eles, né Bel? É bom colocar essas pistas pra (saberem que têm diversas) opções. Eu gostei dessa idéia de usar a lousa pra exemplificar. Mas eu apostaria mais noutra alternativa. Colocar as várias possibilidades lá pra eles não ficarem só com um jeito, fixo, de elaborar o desafio. A criatividade vai de acordo com as escolhas que fazem.

Em primeiro lugar, o excerto demonstra que, na interação colaborativa, as professoras formulam hipóteses para auxiliar Lia. Em segundo, como as soluções são encaminhadas a fim de garantir simultaneamente o caráter lúdico da proposta e a apropriação de elementos da escrita e leitura.

Após ouvir as manifestações das colegas, Lia mostra-se mais confiante: "agora visualizei melhor", concebendo que o jogo sirva "para dar um fechamento para vários assuntos (conteúdos que estejam em foco), né?" Bel intervém, dizendo "é mais um meio...". A formadora repete a fala de Bel ao grupo, reforçando que a validade do jogo está mais centrada no seu papel ativo como mediador de aprendizagem.

Esta última troca de opiniões acentua o caráter díspare na forma como Lia e Bel concebem a prática ludo-educativa. Definir o jogo educativo como "meio" não impede tê-lo também como mecanismo de avaliação da aprendizagem; porém, torná-lo mediador releva sua função educativa, ampliando seu potencial no aprendizado. 
Toda a discussão travada entre Lia e as outras docentes do grupo é muito frutífera. Refletindo sobre a atividade, encontram mecanismos favorecedores da produção escrita pelos alunos de $1^{a}$ série e tecem idéias novas para suas próprias turmas. Também é relevante 0 fato de que, referenciando-se no material didático que Lia utiliza, uma das professoras apropria-se dessa informação para expor suas idéias.

Raramente Lia protagoniza situações de questionamento como a do episódio acima. A rigor, Bel é quem costuma perguntar, para operacionalizar o jogo e caracterizar sua execução. Suas indagações são mais elaboradas porque refletem hipóteses, como exemplificam os dois casos a seguir na mesma reunião de planejamento do Percurso.

No primeiro, tão logo a formadora elenca os recursos básicos deste tipo de jogo (tabuleiro, dado, peões e cartelas de desafio), Bel comenta: "ah, os meus alunos já conhecem como fazer dados... Quer dizer, fizeram cubos. É a mesma coisa, né?". Na indagação de Bel está implicada uma hipótese para solucionar um dos aspectos de confecção, fornecendo ao grupo um meio de resolver um problema que poderia passar despercebido.

Algum tempo depois, novamente a professora indaga sobre outro recurso lúdico não focalizado: "o que são os peões que você disse? As pecinhas pra mexer no tabuleiro? ...Se os alunos não sabem fazer os peões, vão confeccionar? Como?". Questionando sobre a confecção dos peões, Bel introduz novo assunto a ser discutido e planejado, viabilizando ao grupo refletir diferentes vias de solução. Algumas participantes solicitam da formadora um modelo de confecção que lhes recorda o uso de botões e miniaturas feitas de papel dobrado, utilizados em jogos apresentados no início do ano. Outras optam pela obtenção de objetos substitutivos, como pedaços de papel colorido, pedacinhos de borracha, etc. Bel acompanha as sugestões sem se posicionar verbalmente.

Os resultados das últimas conversações são vistos na prática. Na data combinada com Bel, os tabuleiros e dados já estão prontos, ambos confeccionados dias antes pelos educandos. 0 produto final surpreende pelo visível cuidado na confecção. No traçado do percurso, alternam-se casas vazias (sem obstáculo) com as que contêm figuras indicativas dos obstáculos (bomba, nuvem negra, buraco, muro, lago, entre outros). Os dados são firmes e, na maioria, de tamanho grande.

Em relação aos peões, Bel utiliza uma via distinta às soluções debatidas. A professora não instrui os alunos sobre a elaboração dos peões. Tão somente distribui massa de modelar, sugerindo que seja utilizada na confecção das peças. Com a disposição desse material, as crianças criam seus peões personalizados: pequenas esculturas de animais e figuras humanas, como miniaturas de pessoas, ursos (à semelhança do panda), patos, 
tartarugas, gatos, etc.

Na classe de Lia, a produção dos objetos lúdicos ocorre de maneira distinta. Preocupada com a efetiva realização do jogo, encarrega-se da escrita das cartelas. A confecção dos peões também não é aproveitada como estímulo à criatividade das crianças, pois a professora opta por improvisá-los pelo uso de pequenos pedaços de borracha como substitutos. Somente a criação dos percursos cabe aos alunos.

Retomemos a reunião de planejamento para abordar um último aspecto. Poucos minutos para seu encerramento, a professora Bel retorna à elaboração das cartelas, requerendo anuência da formadora sobre uma nova idéia,

uma coisa mais dos conteúdos das cartelas. Eu voltei nisso só pra completar aquela idéia que a gente tava falando com a Lia, sobre 0 que escrever nas perguntas. Eu estou pensando em expandir um pouco, não ficar só na poesia crua. Fazer uma relação de poesias com elementos da natureza ou animais, ou outra coisa que eles prefiram, dar opções e ver o que acontece. Assim fica mais variado o conteúdo... para o jogo ficar relacionando também aos interesses deles.

Solicitada a explicar melhor sua idéia, Bel continua:

Pensei na Águas de Março ${ }^{62}$, que eles gostam muito. Tem várias referências de natureza que podem ser exploradas mais. Não ficar só no texto em si, mas na criação de imagens sobre a natureza, pensar sobre a beleza da natureza, a harmonia do canto dos pássaros, a água da chuva... É que, na hora em que a gente estava falando sobre as imagens para substituir o escrito, eu acabei fazendo uma ligação com música. Só que pros meus alunos, a música entraria como mais uma referência pra deixar mais rica a escolha deles... Não poderia ser assim?

No primeiro parágrafo, Bel reporta-se a conceitos de ludo-educação enquanto que, na continuidade de sua explanação, trata da caracterização de jogo educativo. A flexibilidade é concebida como elemento integrador da proposta lúdica com as necessidades e interesses dos alunos, garantindo que um mesmo jogo seja articulado de diferentes maneiras. $\mathrm{Na}$ hipótese de Bel, a flexibilização advém do acréscimo de um material. Tornando-se generalizado, esse princípio tende a contribuir para dissipar a preocupação em formar um compêndio de jogos, pois é possível recorrer a uma mesma atividade para contextos diversos do processo educativo.

Na seqüência, Bel visa enriquecer a atividade, acrescentando uma fonte de informação para a confecção dos desafios. Essa vinculação não é um processo simples. Não basta

${ }^{62}$ Bel já inseria canções na rotina de ensino antes do projeto de formação. Nesse caso, faz referência a Águas de Março, uma das obras-primas do compositor Tom Jobim. 
aglutinar os interesses das crianças com as necessidades educativas. Cada elemento precisa se alinhavar aos demais. Na solução proposta, é adicionada uma canção específica, conhecida e apreciada pelos educandos, cuja linguagem poética e estrutura melodiosa complementam o outro tipo de material, os poemas.

No percurso formativo, tais reflexões sobre o jogo educativo surgem na segunda fase quando a sistematização das estratégias do projeto (reunião de planejamento, realização com os alunos e reunião pós-atividade em sala de aula) acontece - para se tornarem recorrentes a partir dessa reunião.

\section{b) Realização do jogo em sala de aula}

Antes de principiar a atividade com a turma de $1^{\text {a }}$ série, Lia informa que, por intermédio de um levantamento com os alunos, foram revistas uma série de informações constantes no material didático para a alfabetização, em que o mundo animal é utilizado como referência.

(Lia) Cada animal corresponde a uma letra do alfabeto. A letra 'A' corresponde ao 'antílope'; a letra ' $L$ ' corresponde à 'Iula'... Agora, estamos na letra ' $\mathrm{L}$ '...

(Alê) Ah... Não importa que 'lula' tenha 'u', que vão ver mais adiante?

(Lia) Não. Só que sempre dá um pouco de confusão... Mas é bom, porque já vão acostumando. É como aconteceu com o antílope'. Agora que viram o ' $\mathrm{L}$ ' lembram do ' $\mathrm{L}$ ' no 'antílope'... Todos os exercícios do "Abecedário" fizeram os alunos não ver só leitura $e$ escrita, mas é bom pra conhecerem os animais. Anteontem, eu conversei com eles sobre tudo que nós vimos, recapitulei tudo. Depois, eu aproveitei as perguntas que a gente foi fazendo e já deixei pronto nas cartelas.

(Alê) Mas você fez o conjunto completo de cartelas? Prá cada grupo?

(Lia) Fiz, não foi muito complicado, não. Só que é demorado, né...

(Alê) Colocou o desafio e aquelas orientações pro jogador. Fez a cartela toda?

(Lia) Foi... Assim, eles ficam com mais tempo pra jogar. Mas o tabuleiro foi eles que prepararam...

(Alê) Quantas cartelas pra cada grupo?

(Lia) Foi oito.

(Alê) Quantos grupos?

(Lia) Preparei pra cinco.

(Alê) Cinco? Então, com quarenta crianças... vai ficar oito crianças em cada grupo? Não é muito?

(Lia) Fica um pouco menos, porque uns alunos saíram, tem trinta e dois...Dá seis por grupo mais ou menos. (sete crianças em dois grupos e, nos demais, seis)

Lia inicia as instruções com a classe. Define que, todas as vezes em que o jogador responder adequadamente à pergunta da cartela, seu peão anda mais uma casa no 
percurso. Não havendo resposta condizente, o jogador mantém seu peão no mesmo lugar.

Em relação aos materiais de jogo, conforme mencionamos antes, todos são preparados previamente, de maneira que a atividade pode ser iniciada imediatamente.

Por esta configuração, o jogo mantém seu caráter lúdico, embora deixe de ter características importantes que o vinculariam à atuação discente no preparo dos materiais e nas decisões sobre as regras do jogo. Principalmente não atende a um de seus propósitos educativos: promover a escrita.

Os registros de diário de campo complementam essas informações:

nas cartelas, com letra de forma, a professora escreveu uma pergunta aludindo a um determinado animal - nome, comportamento, habitat, alimentação. Por exemplo: 'o que o gavião come?'; 'cante a música do sabiá,; 'a lula é parente de qual animal?'; a borboleta voa de dia ou à noite?'; 'onde a arara faz seu ninho?"'.

$\mathrm{Na}$ classe de Bel, o fato de as cartelas serem preparadas pelas crianças altera significativamente a forma como o Percurso é vivenciado.

Quando as auxiliares de pesquisa ${ }^{63}$ chegam à sala, os alunos estão organizados em quartetos, havendo apenas um grupo com cinco pessoas. Os tabuleiros, dados e peões foram confeccionados dias antes e, por recomendação de Bel, os alunos preparam (individualmente e em casa) listas de questões que devem ser aproveitadas para as cartelas.

O material para a elaboração das perguntas foi composto de quatro fontes: cadernos, dicionário, canção "Águas de Março" e poemas reproduzidos nos cadernos (os mesmos que a classe registrou em cartazes dependurados numa das paredes da sala). A professora informa que os conteúdos foram diversos: sinônimos, antônimos, aumentativo e diminutivo de substantivos, adjetivos, coletivos, singular e plural de palavras, etc.

Nas explicações à classe, Bel fornece pistas para a confecção dos problemas, estimulando e respondendo perguntas dos alunos. Considerando a formulação dos desafios um aspecto central da aprendizagem, enfatiza: "vocês vão pegar as perguntas que trouxeram de casa e ver quais vão entrar. Não precisa copiar igual ao que tá escrito. Vocês vão ver quais entram e vão mexer nelas pra escrever, depois, nas cartelas". Em seguida, enumera exemplos de questões com níveis distintos de dificuldade, explicando que

pode fazer perguntas pra pedir o diminutivo, o aumentativo, o plural, 0

\footnotetext{
63 À época em que foram estabelecidos os horários para a realização das experiências lúdicas, a classe de Bel passou a ser apoiada por uma dupla de auxiliares de pesquisa: Mariana Peres Stucchi e Julie Emy Onishi. Na ocasião, nem a formadora nem a professora previram quanto este novo arranjo afetaria o encaminhamento da atividade junto aos alunos. Somente na entrevista final, Bel menciona que, apesar de compreensível, a troca da formadora por auxiliar de pesquisa foi questionada pela turma, havendo suposições de que Alê "não queria mais ir na turma deles, mesmo (que) eles (tenham) gostado das estagiárias (auxiliares de pesquisa)".
} 
antônimo... tudo que a gente tá vendo em Português vale. Ou pode pegar idéias dos materiais, mas não vale copiar, heim? Certo? Tem que inventar em cima do que a gente já fez exercício!

Pra não ficar tão fácil de responder, pode perguntar coisas que não tem só uma resposta certa. Pode fazer perguntas de complete. Por exemplo: 'complete a rima do verso do poema tal'. Também (pode) ser pra adivinhar uma palavra, fazendo o risquinho de cada letra, como faz na forca. Não pode esquecer que precisa dizer uma dica da palavra, uma dica que não vai dar a resposta de bandeja, né? 0 nome do autor de uma história que a gente já leu, um poema, ou outra coisa. Entenderam? Quem pode dar um exemplo do que eu disse?

(Rafael imediatamente levanta sua mão para pedir a palavra) Eu tava pensando no poema Tanto Tempo pra perguntar...

(Bel o interrompe) Tá bom! Não, não... Não fala a pergunta senão não vai poder usar... Já sei que você entendeu.

Bel continua, informando que as cartelas terão três partes: "na primeira, começa dando uma pista sobre o que vai perguntar". Esta parte inicial é incluída pela professora por sua iniciativa. Ela aperfeiçoa o modelo discutido no planejamento balizando-se, provavelmente, na escrita de textos em geral, em que o título e/ou primeiro parágrafo anuncia o assunto.

Voltemos ao diálogo entre professora e educandos:

(Bel) a segunda parte é a da pergunta. E no final, precisa dizer o que vai acontecer se a pessoa acerta a resposta. Se ganha direito de andar mais casas... Por exemplo, jogou o dado e tirou quatro. Aí, anda quatro e cai no obstáculo. Então, o que acontece, classe?

(Luiz) Vê a cartela.

(Bel) Isso!!! Tira a primeira cartela do montinho pra responder. Faz de conta: acertou. Vai receber um bônus... Vamos ver se deu pra entender tudo? Acertou, e daí, o que vai fazer?

(Andréa) Vai andar...

(Bel) É, mas pode andar quantas casas quiser? Assim, se fosse eu lá, eu ia andar até ganhar o jogo. O que precisa saber?

(Luiz) Tem que ver quantas (casas).

(Bel) É!!! Tem que tá escrito na cartela, no final, quantas casas vai andar. Agora, atenção! Se colocar que pode andar muitas casas, o que acontece? O jogo não vai acabar rapidinho? Cada um que acertar não vai nem andar, vai dar pulos, vai sair correndo até o ponto de chegada. Quantas casas é um numero bom pra não acabar logo?

(Gislaine) Duas tá bom.

(Bel) Que vocês acham, classe? Pode ser assim? Acho que tudo bem... Também pode incrementar... Ser uma só, se a pergunta for fácil. Pode colocar três se for difícil... Pode deixar sempre duas... Perceberam?

(Leila) Professora, e se erra?

(Bel) Se erra?! Pode fazer o contrário, escreve na cartela assim: "se acerta, ganha tantas casinhas pra frente. Se erra, volta tantas casinhas pra trás." 
Bel responde à indagação, sem se preocupar com a posição da auxiliar - se concorda ou tem outra sugestão. Essa atitude simboliza maior autonomia para lidar com imprevistos, aspecto fundamental para que a inserção de jogos no ensino se mantenha, mesmo sem apoio direto (em sala de aula).

A seguir, enfocaremos mais detalhadamente a mediação pedagógica das docentes no preparo e na execução do jogo.

Da comparação entre segunda e terceira fases do projeto, a professora Bel demonstra maior desenvoltura no jogo do Percurso, ao contrário da retração que predomina durante o jogo de História do Teatro. Circulando entre os grupos, ela questiona, organiza, incentiva, cuida para que todos estejam em sintonia com a atividade.

Além de se envolver com a organização do cenário de aprendizagem, Bel acompanha e interfere diretamente na aprendizagem dos alunos. No Percurso, assume mais a explicação de objetivo, regras básicas da atividade e procedimentos de confecção dos objetos lúdicos, dialogando com os alunos. Durante a execução do jogo, ensaia novas maneiras de observar o que as crianças fazem e de orientá-las.

Em relação à mediação pedagógica, o jogo de Percurso coloca à prova o que Bel vai consolidar no jogo de Tapão. Enquanto escrevem, as crianças solicitam sua atenção, seja para pedir explicações sobre um procedimento, obter aprovação ou interpelar sobre o tipo de questão a ser feita. As informações prestadas se dão em acordo com o ritmo de cada grupo. Algumas vezes, referem-se à formulação da pergunta e à orientação que define a ação do jogador nos casos de acerto/erro do desafio. Nos casos em que o grupo praticamente está terminando as cartelas, Bel auxilia os integrantes na execução dos passos seguintes. Nos registros, observamos que

os alunos estão absortos na tarefa. O burburinho toma conta do ambiente. A conversa é estritamente dirigida a trocas de informações, a ditar a pergunta ao escriba do grupo, a expressar opinióes divergentes quanto ao que escrever na cartela. Em algumas ocasiões, Bel recomenda à turma em geral ou a um grupo em particular que diminuam o volume de voz.

...Conforme terminam, cada equipe tem suas doze cartelas, o tabuleiro com o percurso, o dado e os peões. Assim, cada quarteto inicia o jogo. São variáveis os meios que escolhem para decidir a ordem seqüenciada de jogadores. Uns optam pelo dois-ou-um; outros jogam o dado para ver quem obtém o maior número, e assim sucessivamente até definirem o integrante a jogar por último. Há grupos em que a decisão é tomada 'naturalmente', por uma das crianças colocando-se como líder, atitude aceita pelos demais.

...Durante o jogo, é comum ver crianças em duplas ou trios lerem coletivamente as cartelas. Todos estão extremamente envolvidos. Demonstram contentamento, sorriem, torcem, comemoram, vibram. 
Pouco se incomodam com quem está ganhando o jogo. Alguém que não tem domínio pleno de leitura conta com a colaboração dos amigos. O jogo transcorre dessa forma em torno de trinta minutos, até o sinal para o recreio.

Nos primeiros minutos de jogo na turma de 1 a série, Lia e formadora circulam entre os grupos, acompanhando e auxiliando as crianças. Porém, da mesma forma que observado em ocasiões anteriores, Lia retorna a sua mesa algum tempo depois que o jogo inicia. Nos registros, observamos que

rapidamente, a primeira rodada chega ao fim nos cinco grupos. $A$ formadora circula entre os grupos, acompanhando a execução da atividade ou intervindo. Ora acrescenta questões não previstas nas cartelas ora solicita que respeitem regras, como a de o jogador da vez não ter direito a uma casa extra quando o grupo contraargumenta a resposta dada.

O jogo prossegue conforme a estrutura original até o momento em que, auxiliado pela formadora, um grupo de alunos elabora uma nova regra:

Durante a segunda rodada, Alê resolve sugerir um desafio adicional, recomendando a um dos grupos que tornem válida a resposta somente se apresentada por escrito. Sem outras intervenções, os alunos são deixados livres para integrarem ou não a sugestão.

Imediatamente os integrantes aceitam a proposta e se reorganizam. Resolvem reiniciar a partida devido à inserção da nova regra... Um dos jogadores tira de seu caderno uma folha. Assim que um deles tem seu peão numa casa com obstáculo, ele retira uma cartela e se põe a anotar na folha do colega a pergunta e a resposta, à semelhança de um questionário... Momentos depois, dois grupos instalados proximamente também incorporam a regra.

Ao realizar a conversa com a classe, mormente dirigida à apreciação da atividade, Lia toma ciência de que o desafio de escrever foi inserido no jogo. Mais que isso, é visto pelos alunos como uma alternativa mais instigadora comparativamente à primeira rodada de jogo, quando as regras seguiram o planejado. Embora não tenha acompanhado a criação da regra durante a execução do jogo, o julgamento positivo das crianças oferece uma oportunidade para a professora refletir acerca de suas concepções, tornando-se elemento fundamental de suas análises na reunião do grupo formativo, como veremos a seguir.

\section{c) Reunião pós-atividade}

Lembremos que a definição das fases é determinada pelas situações que manifestam acentuada ampliação e aprofundamento do processo formativo em direção à apropriação dos saberes ludo-educativos. Assim, é imprescindível alertarmos que esta reunião inaugura a quarta fase, demarcando o início de expressivas transformações na trajetória de 
desenvolvimento das docentes.

Na reunião de avaliação do jogo, Lia não esconde sua admiração pelo empenho dos alunos na tarefa de escrita, embora ressalve que "aqueles alunos que fizeram questionário por escrito estão entrando no alfabético". A formadora indaga se pôde ler os registros, obtendo resposta negativa. Todavia, por tê-los guardado, torna-se possível reaver as produções e avaliá-las.

O principal aspecto observado refere-se ao padrão de qualidade. As letras diferentes asseguram que cada jogador se responsabilizou por escrever sua resposta. É bastante provável que a colaboração tenha ocorrido de maneira contundente, devido à homogenia interna na qualidade dos registros, testemunhando que correções diversas foram feitas em prol da escrita correta. Na folha de um dos grupos, notam-se as dificuldades comuns ao início da alfabetização, quando a criança desconhece alguns dos componentes essenciais da estrutura da língua (alternando a escrita convencional com aglutinação de palavras, escrita imitativa, bem como hipótese silábico-alfabética com correspondência fonética ${ }^{64}$.

Embora a escrita convencional esteja presente somente numa das folhas de registro, a validade desse exercício contribui para Lia julgar que "eles acharam bem mais divertido do que antes (sem a regra de escrever as respostas)" e "dá pra ver que a colaboração do que sabe mais ajuda bem o que não sabe". A partir dessas observações, Lia assevera:

eu sei que eu tenho que aprender a ser menos dominadora. Acho que vou começar experimentando eles fazerem desenhos ${ }^{65}$ como se fosse pra representar o que vai acontecer... Mais ou menos como foi no final do (História do) Teatro... Não vou conseguir soltar os alunos de uma hora pra outra, tem que ser devagar...

Essa não é a primeira vez que a professora se auto-avalia. Contudo, o efeito é notoriamente mais profundo. Além de considerar necessária a mudança de postura, encaminha o primeiro passo para efetivá-la, reavendo uma atividade que, até então, era desprovida de significado para sua atuação. Não menos importante, essas reflexões repercutem favoravelmente na experiência futura, quando Lia experimenta "soltar os alunos", delegando-Ihes a elaboração dos desafios do Tapão.

$\mathrm{Na}$ continuidade desse encontro, a discussão se envereda para a avaliação da

64 Sobre o assunto, sugerimos a leitura da obra Imagens e Letras - Ferreiro e Luria: duas teorias psicogenéticas, de Maria da Graça Azenha. Exemplarmente, a aglutinação ocorre em "acapivar" (a capivara) ou em "dequal" (de qual). No caso de escrita imitativa, letras e sílabas de uma palavra já escrita são repetidas noutra em que tais elementos seriam inexistentes. Segundo Ferreiro, a hipótese silábico-alfabética com correspondência fonética expressa uma fase do desenvolvimento da escrita em que são comuns produções tais como: "aimau" (animal); "boboea" (borboleta); "musca" (música) - os exemplos citados referem-se ao material produzido por um dos grupos de jogadores.

65 Lembremos que, na reunião de planejamento do Percurso, a idéia das cartelas deste jogo conterem desenhos foi uma das contribuições que Lia obteve de suas colegas, apesar de não experienciada na ocasião de realizá-lo. 
aprendizagem de uma maneira geral, sem que as professoras se detenham em fatores específicos da realização do jogo e de sua posterior avaliação com os alunos. Os comentários de Lia ajustam-se ao modelo que seguiu em outras ocasiões em que o assunto foi debatido:

$E$, eu acho assim... tem que priorizar as habilidades, especialmente dentro do conteúdo... quais são as habilidades que estão envolvidas? Precisa saber esta resposta. Precisa estar avaliando se o aluno atingiu aquelas habilidades. É bem psicológico, é mais do desenvolvimento como um todo, sai do conteudista... é difícil saber avaliar... A gente fica horas a fio pensando... por que será que tal aluno não consegue adquirir este conhecimento? Dá uma angústia, sabe? Porque a gente não tem uma avaliação mais a fundo, é só na superfície... É muito aluno, não dá pra dar atenção individualizada. Daí, você vê que tem aluno que chega no fim de um ano inteiro sem a menor noção de escrita e leitura... Quer dizer, dá angústia!

... Dia desses eu vi um programa na (TV) Cultura que a professora estava ensinando só com jogos. Tinha ludo, jogo de palavras... Do mesmo jeito que a gente tá vendo. Só que tem que ter conhecimento especializado. Contar com uma pessoa pra orientar. Aí, vai! E só com umas dez ou quinze crianças por professor, porque assim funciona!!!

Endossando a opinião de sua colega, Bel acrescenta que

ter salas com quarenta alunos é uma barra! Haja imaginação!!! Com os jogos, a gente viu que traz muita coisa boa pra aprenderem, se soltarem, sentirem que podem (são capazes). Mas também dá muito trabalho, especialmente pra controlar o entusiasmo. Teve horas que eu já estava exausta, de tanta animação. Tinha que respirar fundo, ver que estava compensando pra aprendizagem, porque senão desistia e mandava todo mundo sentar nas fileiras e ficar mudo! A coisa boa é que dá pra avaliar cada grupo, chegar perto dos grupos e ver o que estão fazendo. E fica mais fácil de saber como estão indo quando é hora de jogar mesmo, porque aí tem que se virar pra descobrir aquilo que não sabe... pra participar do jogo, ou tem que ter um amigo do lado pra ajudar. Mas fica bem mais fácil de acompanhar...

As análises das professoras explicitam, genericamente, a dificuldade docente em acompanhar a aprendizagem dos alunos.

Lia focaliza o aprendizado de acordo com habilidades implicadas nos conhecimentos escolares e definidas como aspectos do desenvolvimento psíquico a serem 'atingidos' pelos educandos. Apesar de não se estender na explicação, postula que a atenção individualizada é o procedimento privilegiado na obtenção de informações mais precisas, considerando que seja impossível exercê-la, devido às condições de ensino. Nas observações de Lia, a superficialidade da avaliação impõe a dificuldade de apreender as relações entre desenvolvimento e obtenção de conhecimento.

A professora nada sugere sobre mecanismos lúdicos que, acionados, absorveriam as 
funções avaliativas. Suas análises repercutem preceitos que dificultam experienciar a ludoeducação como instrumental profícuo ao aprendizado dos alunos. Os obstáculos se apresentam como intransponíveis, exacerbando o sentimento de angústia.

Mediante um exemplo, Lia reconhece a similitude entre o projeto de formação e outras experiências balizadas pelo jogo, embora generalize um princípio contraposto às pretensões da experiência formativa, pois seria preciso manter a figura do especialista e contar com uma realidade muito distinta da existente na escola.

Ao interpretar os próprios exemplos, Lia comumente se apóia em concepções divergentes aos parâmetros da prática ludo-educativa. Por vezes, suas observações encontram opiniões divergentes no grupo. Pela troca de idéias, há situações em que procura respaldar suas explicações em novos exemplos. Em outros casos, notamos que o diálogo abala alguns de seus pressupostos, implicando na explicitação de incertezas e no desejo de mudar.

No caso em questão, haveria condição de consagrar ao cenário lúdico a capacidade de instaurar práticas avaliativas comprometidas com a aprendizagem, e não com o acúmulo de informações? Seria recomendável advogar que, em território ludo-educativo, a mobilidade docente se ampliaria, promovendo maior dinamismo e complexidade na interação e mediação pedagógicas, bem como na avaliação da aprendizagem discente?

Indicativos de respostas a esses questionamentos encontram-se presentes no posicionamento de Bel. Formulando conclusões a partir da experiência com o jogo educativo, a professora sublinha que a atividade ludo-educativa contribui para os alunos "aprenderem, ...sentirem que podem" e "dá pra avaliar cada grupo, chegar perto dos grupos e ver o que estão fazendo... fica bem mais fácil de acompanhar". Este é um dos principais fatores que tornam o jogo um instrumental que favorece a ação dos alunos - independente de diretrizes da professora - e, ao mesmo tempo, amplia a intervenção pedagógica.

A atuação da professora Bel nos encontros formativos é mais próxima da perspectiva ludo-educativa do que da concretização de jogo, até esta fase do projeto. Aos poucos, as experiências com jogos tornam-se parâmetro para examinar reflexivamente a própria docência, mesmo quando as idéias elaboradas nas reuniões não são acompanhadas de correspondentes mudanças em sua prática. Contando com a parceria das demais profissionais e orientações da formadora, o volume de indagações hipotéticas aumenta gradativamente. Conforme aprimora seus questionamentos e análises, Bel obtém maior condição de se antecipar à resolução de problemas.

Entretanto, ao experienciar os jogos com os alunos, a integração dos diferentes aspectos que envolvem a ludo-educação não se apresenta consolidada. Bel se apropria de alguns; outros, ignora. Este é o caso da avaliação discente do jogo. Sua relevância, as maneiras de 
ser efetivada e a função que desempenha no processo de ensino são temas enfocados e valorizados por todas as professoras, inclusive Bel e Lia; contudo, a tônica na simples apreciação da brincadeira se perpetua, pelo menos, até a experiência com o Percurso.

Pretendendo dimensionar o número excessivo de alunos como um obstáculo contornável, a formadora explica que, em princípio, é previsível que o envolvimento dos alunos com o jogo gere um entusiasmo que sobrepuja o compromisso com as regras, dificultando 0 encaminhamento da atividade. Porém, prosseguindo à inserção de jogos, as próprias crianças passam a se empenhar em obedecer aos princípios reguladores da atividade. Visando à manutenção do jogo, tornam-se mais capazes de superar uma vontade individual.

0 trecho seguinte focaliza as falas de Lia e Bel acerca do assunto, demarcando relações que constroem entre autocontrole do comportamento e elaboração das regras de jogo. Alê reporta-se à regulação das atitudes das crianças durante a atividade lúdica, ao que Lia diz:

(Lia, para Alê) Eu acho que você reparou bem no que acontece. Eu vivo dizendo pra eles: 'não adianta responder qualquer coisa. Se sabe, levanta a mão. Se não sabe, não inventa moda'.

(Bel) Se bem que eu acho que isso atrapalha um pouco... porque conhecimento não é informação pura. Conhecimento tem a ver com informações, mas só se estiverem relacionadas. Eu tenho cinco e eu tenho sete. $O$ que vou fazer com os dois números é que acaba sendo o importante (no aprendizado). Se vou somar, se vou subtrair, se vou multiplicar... Vai depender do problema que tenho que resolver. É essa relação que parece que fica faltando pra saberem respeitar as regras... Acho que aí entram duas coisas interessantes de pensar pro planejamento das atividades: primeiro, que não dá pra ir, logo de primeira, propondo uma situação que seja muito complicada. Por exemplo, um jogo com um monte de regras. É melhor começar com jogos mais simples.

(Alê) Se eu tô entendendo direito, o que você (Bel) tá propondo é que, pros alunos terem um comportamento mais adequado, o jogo tem que ser mais simples. É isso, né, Bel?

(Bel) Acho que é isso... Eu fiz uma ponte meio confusa com o conhecimento... Conteúdo versus regras... Quer dizer, normalmente a gente só se preocupa se eles tão aprendendo os conteúdos. Com o jogo, a gente precisa se preocupar se tão sabendo jogar direito, porque só assim vão aprender... Deu pra entender?

(Lia) Ah, agora que eu vi de onde que você tirou a idéia de menos regra...

A formadora recomenda que a discussão prossiga. Todo o grupo se manifesta. $\mathrm{Na}$ seqüência, Lia e Bel voltam a se posicionar:

(Lia) Tem que mexer nas regras. Quando a gente tá ensinando um conteúdo, também vai aos poucos. Com jogo é igual.

(Bel) Mexer nas regras? É! Só que... como vai fazer? Ficar com menos regras? 
Ao se referir à situação de aprendizagem, a professora Lia observa paralelos entre jogo e ensino, levando Bel a elencar algumas indagações.

Em síntese, os pressupostos e hipóteses formulados pelas professoras poderiam ser expressos da seguinte maneira: o comportamento dos alunos está condicionado ao nível de complexidade do jogo. Resta saber: essa complexidade poderia ser medida pelo modo de estruturar suas regras? Considerando que a resposta seja afirmativa, Lia propõe que, para simplificá-lo, "tem que mexer nas regras", priorizando a alteração ou diminuição do conjunto de regras. 0 que determina questionar se o procedimento escolhido pode ser generalizado para qualquer contexto.

A discussão fundamenta decisões de extrema relevância. Para servir como mediador, importa menos definir qual o jogo. É preciso adequá-lo, objetivando sua função educativa entre 0 desenvolvimento real e o desenvolvimento potencial, no limiar entre 0 que os alunos são capazes de realizar com autonomia e o que podem fazer com ajuda do jogo, equilibrando o nível de complexidade da atividade lúdica.

De acordo com o nosso referencial, a caracterização do jogo - regras, materiais e procedimentos - define seu potencial para contribuir com o processo de ensinoaprendizagem. Toda determinação apriorística é arriscada na medida em que retira da atividade lúdica sua qualidade de se flexibilizar, adequando-se a diferentes contextos. No entanto, alguns princípios devem reger as escolhas que o educador precisa fazer para definir como e para que inserir uma atividade lúdica. Nesse sentido, a comparação com os conteúdos escolares sugerida pelas professoras é valiosa. Entre um e outro contexto ludoeducativo, devem valer as mesmas diretrizes. Quais são elas? Essencialmente, a repetição de um mesmo jogo para que professoras e alunos se apropriem de seu formato geral; não uma repetição ipsis litteris, mas sempre determinada por rearranjos de características da atividade, cuja adequação se relaciona ao objetivo educativo e ao desenvolvimento dos educandos.

Essas explicações são desenvolvidas pela formadora durante o debate sobre 0 assunto. As professoras seguem hipotetizando e analisando. A dificuldade em solucionar o problema é expressa na necessidade de alongar o diálogo até o próximo encontro. As intervenções da formadora contribuem para esclarecer alguns aspectos do assunto, mas não são suficientes. Uma compreensão mais abrangente principia somente quando Alê se vale de exemplos hipotéticos de alteração da estrutura de regras do jogo; redução do número de regras e casos em que é preferível ter em conta os dois fatores, destacando os elementos essenciais para balizar as decisões.

Entre a segunda e quarta fases, o jogo de Percurso pode ser considerado um 'divisor de 
águas'. Comparando a reunião de planejamento do História do Teatro com a desse jogo, o clima ansiógeno já não existe. Há avanços importantes na realização do Percurso, sobretudo no caso de Bel.

O comportamento de Lia é paradoxal. Além de ter maior experiência profissional, a professora conta com vivências anteriores de uso de jogos, leituras e cursos sobre o assunto. No entanto, a atitude diretiva e controladora se opõe às características que fazem do jogo um instrumental de desenvolvimento da autonomia discente. Utilizar um jogo que desafie as crianças de $1^{\text {a }}$ série a 'escrever' parece-lhe absurdo, pois, além de não terem domínio da escrita, seriam incapazes de encontrar soluções sozinhas devido à 'imaturidade'.

Nas reuniões, é raro Lia levantar questionamentos. Em contraste, é a principal fonte de exemplos e uma exímia narradora. Sempre muito dinâmica e comunicativa, tem presença forte no grupo. Freqüentemente é a primeira a se pronunciar, espontaneamente ou em função de uma solicitação da formadora. Tal postura produz um clima afetivo extremamente favorável no grupo. As descrições de Lia tornam-se fonte de investigação, embora sejam poucas as vezes em que é empreendida por ela própria.

As idéias que Lia formula dificultam encaminhar soluções e colocá-las em prática, especialmente porque se contrapõem aos princípios que regem a prática lúdica de ensino.

Ao contrário, a inexperiência de Bel parece contribuir para questionar tudo que se discute, auxiliada pelas intervenções da formadora e explanações das companheiras. Utiliza a indagação como principal recurso para analisar e extrair hipóteses que lhe permitam prever obstáculos na realização da prática lúdica de ensino, buscando resolvê-los antes mesmo de se concretizarem.

Essas distinções repercutem na conceituação que elaboram. Para Lia, a função do jogo é 'dar um fechamento' ao que foi ensinado; para Bel, é um mediador do ensino.

As professoras também divergem na realização do jogo. Enquanto Lia não se apropria de nenhuma das sugestões das colegas para que seus alunos escrevam as cartelas de jogo, Bel as utiliza para incrementar as fontes de informação que serão utilizadas na elaboração dos desafios.

Contudo, ao contrastar a qualidade do jogo entre sua turma e as demais, Lia se reavalia, ensaia novos procedimentos, arrisca-se. Continua testando, mesmo que nem sempre seja viável aliar os anos de experiência no ensino estruturado previamente e controlado com práticas que requeiram "ser menos dominadora", possibilitando que alcance mais do que "soltar os alunos", mas que possa incentivá-los e orientá-los para que atuem com autonomia. 


\subsubsection{3 - Análise do Jogo de Tapão na Matemática - 4ạ Fase do Projeto Formativo}

A 4a fase é definida pela maior desenvoltura das professoras. Alguns elementos, ainda incipientes, mas de extrema importância na constituição de práticas ludo-educativas emergem, sobretudo no percurso formativo da professora Bel. Na discussão dessa fase serão incluídos aspectos das anteriores, cuja interpretação é melhor produzida por intermédio de comparações com o material sobre o jogo de Tapão.

\section{a) Reunião de planejamento}

No décimo sétimo encontro, destinado ao planejamento do jogo, as estratégias formativas seguem o mesmo padrão estabelecido desde que atividades lúdicas passaram a se realizar com os educandos. A formadora apresenta o jogo e o grupo define como será inserido na aprendizagem, considerando que seu preparo e execução sejam vinculados a diversos aspectos do processo de ensino-aprendizagem. O foco central é o ensino de conceitos matemáticos, correspondendo ao programa curricular de cada série e às especificidades de cada turma. A desenvoltura de Bel e Lia é muito maior, comparativamente à reunião de planejamento do jogo de Percurso. Bel mantém o mesmo comportamento observado nas reuniões anteriores, a peculiaridade de indagar, mas é sobretudo na antecipação de problemas para a execução do jogo que transparece maior qualidade. Por seu turno, Lia continua fornecendo ao grupo exemplos de suas experiências anteriores, procurando apontar noções gerais sobre a realização do jogo. Entretanto, algumas das soluções encaminhadas por Lia confrontam-se com aspectos centrais da ludo-educação, tornando-se núcleo do aprofundamento do debate.

Na turma de $1^{\text {a }}$ série, o jogo objetiva cálculos com somas e subtrações de dezenas, segundo proposição de Lia. A professora acredita que os exercícios existentes nos cadernos das crianças, realizados e corrigidos, sejam a principal fonte de informação para orientar a ação discente. Observa que, dessa forma, o jogo deve ter a função de solidificar aprendizagens já efetuadas.

$\mathrm{Na}$ classe de Bel, o jogo está relacionado a cálculos com multiplicação, devendo estimular a coordenação dessa operação matemática básica com as demais. Bel prevê que seus alunos não sejam capazes de criar problemas articulando duas ou mais operações matemáticas e que a divisão não seja uma delas, haja vista que à época do jogo os alunos têm apenas duas aulas introdutórias do assunto. Porém, na realização do jogo, notamos que as duas hipóteses da professora não se confirmam - as crianças criam situações envolvendo mais de um cálculo, e com divisão, além de se sentirem livres para utilizarem numerais bem maiores 
que o usual.

O jogo de Tapão envolve equipes que disputam umas com as outras. É composto de cartelas de situações-problema e cartelas-resultado. Mesas dispostas no centro da sala servem para alocar as cartelas-resultado. Quando o jogo inicia, as equipes se posicionam ao redor dessas mesas. As cartelas-problema são entregues à professora para que leia, uma a uma. A cada problema lido, as equipes se organizam para resolvê-lo. 0 grupo que obtém o valor final, conta com um representante incumbido de bater numa das cartelas-resposta expostas nas mesas centrais. A equipe que resolve mais rapidamente obtém um ponto/rodada (registrado no quadro-negro), desde que a resolução do problema seja explicada.

Essa descrição do jogo não é uma caracterização fornecida pela formadora; reflete a ativa participação das professoras na reunião de planejamento. Mediante observações acentuadas por Lia, define-se a organização do cenário para garantir que todas as crianças participem da atividade. Bel é uma das principais protagonistas no encaminhamento de soluções como, por exemplo, a de unir a obtenção de pontos com a explicação do raciocínio utilizado, pois, como ela mesma diz: "evita chute".

De modo geral, o grupo assume a estruturação do jogo. As professoras tomam diversas decisões; uma das essenciais é ampliar o espaço de atuação autônoma dos alunos, delegando-Ihes inteiramente o preparo das cartelas que contêm os desafios (situaçõesproblema).

Há, no entanto, novas aprendizagens a se consolidar. Em meio ao início de um novo assunto tematizado por uma das professoras, Lia diz:

\section{Antes de pensar nisso, tem um outro ponto... nós precisamos pensar em como explicar a confecção das cartelas... E se pular essa parte? Pra adiantar, eu acho que vou trazer elas (as cartelas) já cortadas (no formato).}

A formadora interroga Lia quanto à exclusão dos alunos no recorte das cartelas, ao que a professora responde: "não tem tesoura pra todo mundo".

Depois de indicar o problema e buscar facilitar a confecção, a professora propõe se incumbir da tarefa, argumentando que dessa forma é dispensável explicar os procedimentos aos alunos, agilizando a implementação do jogo. Contudo, outras medidas poderiam ser adotadas para evitar redução de tempo de jogo - fator de preocupação da professora. Por exemplo, realizar a confecção antes da data prevista à realização do jogo, como atividade vinculada a trabalhos manuais que, apesar de existirem na escola, não têm vínculo com a 
aprendizagem em geral ${ }^{66}$.

Há outro aspecto relevante. Trata-se de uma solução que, generalizada, traz sobrecarga à ação docente. Supondo a inserção rotineira de jogos, que condições levariam Lia se dispor a recortar inúmeras cartelas a fim de entregá-las prontas aos alunos? E nos casos em que o objeto lúdico demandasse mais que o recorte de retângulos de cartão? Optar por essa solução não incorreria num obstáculo adicional a práticas ludo-educativas? Mesmo não sendo objeto de ensino específico, não seria válido aos alunos vivenciarem os preparativos do jogo, desde os relacionados sobremaneira ao exercício psicomotor? No caso em questão, as sugestões das colegas enriquecem a discussão, apesar de Lia efetivamente, na data de realização do jogo, recortar as doze cartelas de cada uma das sete equipes, num total de setenta e dois retângulos de cartolina.

A opção da professora também surpreende porque, na experiência com o Percurso, o número 'insuficiente' de tesouras não impediu a confecção dos tabuleiros, concretizada em pequenos grupos e previamente à data de realização do jogo. Assim, no que diz respeito a alguns mecanismos envolvidos na organização do cenário de aprendizagem, soluções encontradas e vivenciadas na experiência anterior não puderam instrumentalizar novas decisões.

É relevante contextualizarmos a sugestão de Lia. Desde os primeiros encontros, a professora traz ao grupo formativo experiências anteriores - lúdicas ou não - que revelam sua maneira de conceber o processo de ensino-aprendizagem. Suas observações e reflexões indicam que toda atividade educativa deve ser estruturada e guiada pelo educador, contrariando princípios norteadores da abordagem ludo-educativa, tais como o de conceber o preparo dos jogos - etapa importante de aprendizagem e desenvolvimento, promovendo a resolução autônoma de problemas, a colaboração e os processos metacognitivos.

A cada nova experiência e, principalmente, através dos encontros em que se avalia a execução do jogo, Lia inspira-se gradativamente nesses princípios. Na vivência com o jogo de Percurso ainda precisa 'facilitar' a ação discente; no entanto, de modo algum se responsabiliza pela formulação dos desafios. Ao delegar às crianças uma das ações centrais da prática ludo-educativa, Lia demonstra uma alteração substancial na forma como concebe o jogo educativo, aproximando-se um pouco mais da formulação de um saber-fazer lúdico.

\section{b) Realização do jogo em sala de aula}

Ao ser concretizado o Tapão com os alunos da 3a série de Bel, a professora demonstra maior confiança na capacidade das crianças se organizarem sozinhas do que observado na

\footnotetext{
${ }^{66}$ Detalhamos uma parcela desse gênero de atividades no item 5.2.2.
} 
terceira fase. Por esse motivo, encaminha as instruções sem nenhuma necessidade de apoio, apesar de ter ao seu lado a auxiliar de pesquisa ${ }^{67}$.

Inicia as explicações retomando a experiência realizada com o mesmo jogo na segunda fase; também ressalta semelhanças com o jogo de Forca, familiar aos alunos.

Em relação ao jogo de Forca, sugere similitudes no formato e na função das equipes de jogadores para enfatizar a cooperação entre seus integrantes. Em função das regras do jogo, Bel recomenda agilidade para a resolução dos problemas. Menciona que o desempenho da equipe pode ser melhor se houver distribuição de tarefas que compõem o jogo. Com alguns exemplos, explicita a relação entre agilidade e desempenho e detalha a caracterização do jogo, auxiliando as crianças a compreender a dinâmica da atividade.

Bel fornece explicações, mas não se delonga em exemplificações. Tende mais a lançar uma pergunta. Assim, ao abordar a experiência passada com o Tapão, solicita à classe que se recorde das regras, averiguando a compreensão das crianças quanto à configuração do jogo. Com as perguntas orientadoras de Bel, os alunos se responsabilizam pela explicação sobre a atividade.

Quando necessário, professora e auxiliar de pesquisa complementam as explicações. Bel procura ampliar e precisar as idéias formuladas pelos alunos. Por exemplo, após um aluno definir o Tapão como "um jogo de números", ela acrescenta que se trata de "uma competição de problemas de matemática". Na forma em que o diálogo é produzido, é perceptível a mudança das interações professora/alunos ocorridas no decorrer do projeto.

Somente num aspecto, Bel insiste mais no detalhamento das explicações, sugerindo que “precisa ficar atento na hora em que eu ler o problema. Não dá pra todo mundo falar junto. Tem que ouvir os problemas... Quando terminar, os grupos vão se organizando rápido para resolver". A fim de oportunizar que todos os membros de uma equipe experimentem bater na cartela, a professora alerta para que estabeleçam rodízio entre seus jogadores, "cada jogada é a vez do primeiro do grupo; bateu, é a vez do próximo".

Terminadas as instruções, os alunos assumem todo o preparo do jogo, contando com pistas, questionamentos e explicações de Bel.

A professora conduz o preparo da atividade de uma maneira distinta do que foi previsto na reunião antecedente. Conjuga explicações com observações da ação discente, entremeada com algumas problematizações. Esse modo de empreender a atividade propicia o maior engajamento dos alunos na organização do cenário de aprendizagem ludoeducativa.

${ }^{67}$ Por intermédio de reuniões entre formadora/pesquisadora e auxiliares de pesquisa, estas são instruídas a contribuírem com a professora somente se requisitadas. 
Pressupomos que, na eventualidade de Bel prosseguir com a inserção de jogos educativos no processo de ensino-aprendizagem, crie alternativas ainda mais elaboradas, enfatizando a observação do que as crianças falam/fazem e a problematização, através de perguntas orientadoras. Desse modo, o preparo do jogo amplia sua função na aprendizagem pelo predomínio de ações docentes que estimulam a autonomia dos alunos.

No caso da turma de $1^{\text {a }}$ série, Lia se detém mais nas explicações por considerar difícil às crianças da faixa etária com que trabalha (de sete a oito anos) contribuírem com a caracterização do jogo, pois "são imaturas demais". Praticamente não questiona. Utiliza o quadro-negro para exemplificar como a classe deve proceder e indicar regras do jogo e seqüência de tarefas a serem realizadas.

Postulando que as crianças são "imaturas", a professora assume a responsabilidade pelo enquadramento da atividade e direcionamento da ação dos alunos. Coerentemente, Lia pauta sua atuação nos pressupostos pedagógicos em que acredita, conforme atesta 0 fragmento a seguir, extraído do encontro subseqüente à execução:

Então, a atividade foi bem de recapitular (conteúdos ensinados) mesmo... Pra eles ficarem mais na percepção do conjunto (das regras); ver que uma regra tá vinculada com a outra. Ainda é uma coisa que precisa ser explicada e explicada e explicada... Acho que tem um pouco a ver com a idade, né? Eles são novinhos ainda...

Na seqüência das instruções, Lia informa à classe que o propósito do jogo é rever conceitos já aprendidos, aludindo a exercícios feitos nos cadernos como fonte essencial de onde devam retirar exemplares que sirvam de referência para a aplicação de cálculos com adições e subtrações.

Permanece a atitude de aguardar a intervenção da formadora, embora menos acentuada que nas experiências anteriores.

Todavia, não nos furtemos em apontar os avanços dessa professora no encaminhamento deste jogo. Lia incrementa a experiência do Tapão ao delegar à classe sua estruturação, desde a elaboração dos materiais necessários à atividade.

Essa alteração em seu percurso formativo tem origens no primeiro encontro desta fase, inaugurada pela avaliação do Percurso. Ao defrontar-se com a diferença de qualidade de execução do jogo entre sua classe e as demais, a professora conclui que 0 fato de seus alunos não terem vivenciado o preparo influencia na articulação do jogo com o processo de aprendizagem. É por meio dessa confrontação que Lia se manifesta favorável à organização do cenário ludo-educativo como oportunidade ao exercício da criatividade e, sobretudo, à funcionalidade do jogo para a educação.

Anteriormente, não parecia haver mérito algum em organizar o cenário de aula com a 
'co-operação' dos educandos. Pelo contrário, aparentava desgastante e contraproducente. Agora, Lia não apenas se dispõe a considerar tal empreendimento válido como efetivamente o põe à prova, vislumbrando que possa ser agregado a sua atuação.

Em função do tempo de duração do projeto, não pudemos comprovar mudanças mais efetivas na prática de Lia. 0 fato de manter o jogo como útil ao 'fechamento de um assunto' limita seu campo de ação como mediador de ensino. No entanto, suas ações e reflexões sobre os procedimentos de organização do cenário de aprendizagem se tornam claramente mais pertinentes aos princípios da ludo-educação.

Com relação à execução do jogo de Tapão, detemo-nos na mediação pedagógica ${ }^{68}$ circunscrita pelas seguintes ações docentes: definir conceitos, descrever objetos de conhecimento, argumentar por explicações e proposições, problematizar.

Vejamos um excerto ilustrativo da mediação da professora Bel, na etapa correspondente à elaboração de cartelas-problema e cartelas-resultado, ao final do preparo do Tapão:

A turma está dividida em grupos de cinco integrantes. Num desses grupos, dentre várias situações-problema escritas numa folha de rascunho, lê-se: "Fabiano tem 5641 bolinhas de gude. Leandro tem o triplo de Fabiano. João tem a metade de Leandro. Quantas bolinhas tem ao todo?".

Após algum tempo observando a produção do grupo, Bel indaga: "que conta vai ter que fazer pra saber quanta bolinha o João tem?". A resposta de Ricardo, um dos integrantes, faz a professora sorrir $e$ comentar: "e não é uma divisãozinha, né?".

Porém, é preciso alertá-los para o fato de que "o número de bolinhas tá grandão demais". Bel sugere "dar uma diminuída na quantia de bolinhas... Tá certo que não é pra fazer muito fácil, pra ninguém saber a resposta só fazendo de cabeça, mas assim vai demorar demais... se for de duas casas (dezenas), mesmo assim fica dificinho..."

Concordando, uma das crianças providencia a alteração, dizendo: "É. Vamos tirar!". Outro aluno é mais explícito: "Vamos tirar a parte do João... Só o Leandro e o Fabiano".

Assim que Bel deixa os alunos, a cena protagonizada por eles finaliza, pois a filmagem segue o movimento da professora, e não da turma.

Algum tempo depois, Bel retorna ao mesmo grupo e observa que, para lidarem com o problema, retiram o último dos componentes. Julgando que a idéia inicial oferece uma complexidade de resolução maior, por envolver multiplicação, divisão e soma, procura reavêla com os alunos, questionando: "Olhem só! Vocês tiraram a parte da divisão, não foi? Tudo bem. Mas vocês podem escolher... ter várias contas com números menores ou só ficar com

\footnotetext{
${ }^{68}$ No quarto capítulo, explicitamos as diferenças do tema Mediação Pedagógica com o de Interação Social.
} 
número grande e menos conta. O que vocês preferem?". Gestualmente, a professora procura expressar sua própria preferência. Para o primeiro caso, abre os braços; no segundo, quase une o polegar e o indicador de uma mão.

Ignorando a linguagem gestual da professora, um dos alunos é enfático: "número grande com menos contas". Considerando que não deva intervir mais, Bel concorda e elogia a produção, encaminhando-se a outro grupo. ${ }^{69}$

No fragmento, além da mediação, há também os temas Interação Social e Avaliação de Aprendizagem. Vamos nos deter na mediação de Bel.

Oferecendo pistas aos componentes do grupo, a fim de que reformulem o enunciado, a professora se utiliza de explicações e exemplos. Mas é sobretudo por anunciar o problema do numeral "grandão demais" que ela os encaminha para a avaliação do grau de dificuldade do enunciado original.

Na mediação, Bel investiga a atuação discente, propondo desafios e potencializando as aprendizagens em processo. Regula a ação presente referenciada na futura, reconhecendo e estimulando as competências das crianças, observando e problematizando.

Todavia, novas conquistas são necessárias. Não podemos julgar sua mediação plenamente integrada. Se é verdade que em determinados momentos - como ilustra o excerto acima - o comportamento da professora muito se aproxima de uma abordagem ludo-educativa, noutros - como veremos adiante - o nível de complexidade de suas intervenções ainda é bastante lacunar em aspectos essenciais para se fortalecerem os laços entre ensino e jogo.

Com relação ao desenvolvimento de Lia, as mediações são menos freqüentes. Entretanto, duas mudanças distinguem sua atuação em comparação com o jogo de Percurso: a professora circula mais durante a atividade, a fim de observar a execução do jogo, e são bem menores a diretividade e o controle.

As distinções no desenvolvimento de Lia e Bel continuam se sustentando. É impossível Lia se desligar dos princípios educativos formados ao longo de sua carreira. Em parte, tal condição contribui para compreendermos por que Bel se arrisca mais, não impedindo, por exemplo, que seus alunos criem os problemas de matemática, ainda que possam ignorar conceitos e aspectos do aprendizado que ela considera relevantes.

Em contrapartida, Lia instrui para que os problemas sejam 'criados' a partir do que já

69 O fato de serem os alunos os responsáveis pela criação dos problemas propicia situações adversas. $\mathrm{Na}$ eventualidade de terem mantido 'João' e o número proposto no problema, as crianças teriam de se haver com um cálculo que lhes é completamente estranho: divisão que resulta em número decimal. Segundo o referencial que embasa a abordagem da ludo-educação, isso não se constitui um aspecto negativo, fazendo parte do processo de ensino. 
existe, nos cadernos.

Enquanto a professora Bel avalia que o aluno seja capaz de tomar algumas decisões, Lia pondera que o trabalho com crianças mais novas precisa de maior direcionamento, pois elas são 'imaturas demais'. Como Bel, Lia não desacredita no potencial do jogo, embora seja difícil coordenar a prática ludo-educativa à pré-existente.

Discutiremos, agora, outro aspecto importante na realização de práticas ludo-educativas: a avaliação discente do jogo. No percurso formativo, essa etapa efetiva-se somente na quarta fase e exclusivamente na turma de Bel. Nas demais fases do projeto e dentre as outras professoras, o procedimento caracteriza-se pela sondagem de impressões quanto ao prazer despertado pela atividade e ao respeito a regras de comportamento.

Segundo os princípios da ludo-educação, a avaliação do jogo com os alunos é um tema demarcado pela sistematização do aprendizado de saberes escolares (conhecimentos de determinados conteúdos escolares) e promoção do desenvolvimento de competências (processos como metacognição, generalização e descontextualização).

Avaliar a atividade, descrevendo ordenadamente o que ocorreu durante sua execução, é um elemento fundamental para a aprendizagem. Não é suficiente o jogo em si. Avaliá-lo proporciona a auto-avaliação (metacognitiva) dos alunos e a generalização dos conhecimentos envolvidos na ação lúdica, além de ser útil para que elementos da atividade sejam descontextualizados, isto é, sínteses dos saberes e modos de atuar implicados na experiência respaldem 0 aprendizado ulterior. Processos metacognitivos ocorrem assistemática e dispersamente no acontecer do jogo. Por isso, é imprescindível debaterem e, inclusive, registrarem - o que conheciam, passaram a conhecer e o que visam saber, mediante a vivência lúdica.

Portanto, o objetivo dessa avaliação é propiciar à classe reaver como a proposta foi delineada, observar a interdependência de procedimentos e regras com abordagem de saberes escolares, discutir como se firmaram as interações, bem como avaliar a concretização da atividade lúdica de maneira global, buscando aprimorá-la para ensejar novas experiências.

Para desenvolvermos a análise desse tema, reportamo-nos ao material sobre as duas professoras relativo ao jogo de História do Teatro. Depois, enfocamos a avaliação que Bel realiza com seus alunos, logo após o Tapão na Matemática terminar.

Na realização do jogo de História do Teatro, considerando válido enriquecer a atividade com a introdução de registros feitos pelas crianças, a formadora propõe à Lia retratarem as encenações em desenhos, havendo liberdade para redigirem título ou alguma informação sobre a cena representada. Não se trata de algo previsto, pois, na reunião antecedente, 
avaliar o trabalho com os alunos foi um aspecto tão-somente indicado. Além de aprovar a sugestão e colocá-la em ação, no dia seguinte, Lia entrega bilhetes a cada aluno, como os seguintes:

Beatriz, seu desenho foi muito criativo. Parabéns! Eu posso ver pelo desenho que cada peça tinha uma ficha que o "Senhor do Tempo" lia antes de começar, para saber como era a história. Beijos da professora ${ }^{70}$.

Vitória, adorei seu desenho! Está todo mundo bem enfeitado com perucas e flores. E tem também a lousa para nós vermos que tudo aconteceu na sala de aula!

Paulo, adorei o seu desenho. É muito criativo. Tem os dois guerreiros lutando com as capas e enfeites na cabeça. Também foi uma boa idéia desenhar as mesas e os outros alunos assistindo à peça.

Carlos, o seu desenho do Teatro dos Samurais ficou lindo! Até parece uma foto da peça, com os cinco samurais enfeitados, prontos para lutar. Pelo seu desenho, eu vejo como foi divertido brincar de teatro!

Valéria, o seu desenho do Romeu embaixo da mesa ficou lindo! Gostou da história de amor do Romeu e Julieta ou gostou mais da briga das familias?

Cristine, adorei seu desenho da história do leão. Foi divertido ver o leão correndo atrás dos "homens da caverna".

Aurora, o deus Baco já tinha ficado contente com o canto do seu grupo para fazer as uvas crescerem. Mas ele ficou ainda mais contente depois que viu o seu desenho...

Sérgio, o seu desenho é muito interessante. Sabe por quê? Porque você desenhou a sala com as cadeiras do jeito que nós arrumamos para brincar de teatro. E também me desenhou escrevendo os desafios na lousa. Que idéia genial!!!

No caso da turma de 3 a série, a mesma sugestão da formadora é aprovada, com a produção de textos substituindo os desenhos: ${ }^{71}$

hoje aconteseu uma cohiza (coisa) muito feia

um homem gostava de uma menina

e ele não queria ficar loge (longe) dela

e depois ele matol ele (suicidou-se)

e a menina ficou muito chateada com a mãe dela

São Paulo, 4 de Julho Luciana 3a serie $A$

Eles colocarao as mascaras

Romeu del a flor para julieta

Julieta esta chorando porque romeu pepeu (bebeu) veneno

Julieta beija a boca de romeu e também more

\footnotetext{
${ }^{70}$ No exemplo em questão, somente no primeiro bilhete reproduzimos a frase "beijos da professora" que, na verdade, é repetida em todos.

${ }^{71}$ Mantivemos a forma original. Nos casos em que é necessário, apresentamos entre parênteses uma correção ou informação complementar.
} 


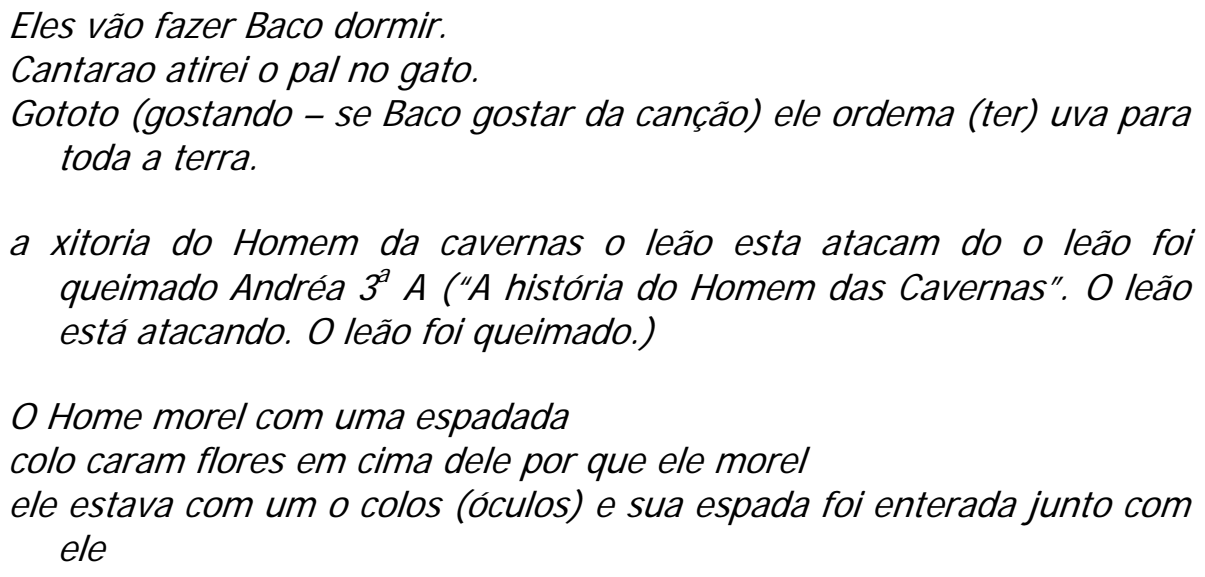

Segundo Lia, na reunião subseqüente, os alunos apreciam os recados dos bilhetes e manifestam acentuado interesse em repetir a brincadeira. Embora seja inconteste a iniciativa da professora, os bilhetes têm propósito exclusivo de elogiar a tarefa realizada. Nenhuma outra conseqüência se sucede. Por seu turno, Bel também não realiza alguma atividade a partir dos textos dos alunos. As apreciações não são suficientes para demarcar os aspectos mais relevantes, potencializadores de reflexão quanto à relação desses registros com a aprendizagem das crianças. As professoras também não indicam se pretendem propor a avaliação com os alunos a partir dos materiais produzidos.

A avaliação com o corpo discente, enquanto procedimento destinado a ampliar, aprofundar e sistematizar a aprendizagem, inexiste na atuação de todas as docentes envolvidas com o projeto, até o Tapão.

$\mathrm{Na}$ execução do Tapão na classe de Bel, transcorridos aproximadamente trinta minutos de jogo, a professora observa que todos os jogadores de cada equipe tiveram oportunidade de se responsabilizar por bater na cartela-resposta. Em função disso, considera que seja propício finalizar a atividade, propondo e organizando a avaliação.

Primeiro, convida os alunos a explicarem oralmente as regras do jogo. Assumindo a função de 'escriba', Bel transcreve as opiniões dos alunos no quadro-negro, solicitando que copiem esses registros em seus cadernos, de modo que sirvam ao exercício da escrita. Quando julga pertinente, reformula a explicação dada, num tom interrogativo, objetivando que os alunos se posicionem, concordando, discordando ou complementando:

(Fernando) O primeiro da fila é que resolve o problema.

(Bel) Então, pra bater, cada grupo faz uma fila? Em cada jogada é a vez de um do grupo, certo? Todo mundo teve a sua vez de bater?

(classe responde afirmativamente)

(Bel) Mas é só o primeiro (jogador) que tem que resolver? Os companheiros não ajudam a resolver o problema, não? É assim, é?

(várias vozes se levantam, opondo-se a esta idéia) 
(Andréa) Todo mundo tem que ajudar o outro... na minha vez de ir (bater), eu fui lá e bati na cartela que o Felipe disse... E depois, eu que ajudei a Ezelise... Foi assim, professora! Só o André foi querer bater sem ajuda, por isso que ele não conseguiu (jogador de outro grupo 'bateu' antes).

(Bel escreve no quadro-negro: "no grupo, os alunos precisam se ajudar uns aos outros")

Uma das crianças informa como sua equipe estabeleceu regras internas de comportamento, pretendendo o melhor modo de interagir. Entretanto, a atenção da professora está dirigida à escrita das regras do jogo. Indagar sobre outros sistemas interativos e incentivar os alunos a compará-los seria uma das possibilidades de utilizar a informação para a auto-avaliação discente. Na seqüência do diálogo, outras características da atividade também são abordadas de forma lacunar, ou seja, servem somente para enumerar as regras do jogo, sem exame da funcionalidade para a meta educativa do mesmo.

Embora o avanço de Bel seja evidente, a dinâmica avaliativa constitui-se num nível experimental e performático. Notadamente, a ênfase na descrição e no registro das regras do jogo limita o aprofundamento do debate, que potencializaria a integração dos conhecimentos que estão se constituindo.

Finalizada a escrita sistematizada das regras, Bel debate com a classe o processo de preparo dos problemas, desejando apurar em que medida trouxeram dificuldades a cada uma das equipes e como se encaminharam as soluções. A professora tem ciência de que é importante incentivar os alunos a reavaliar os conteúdos dos enunciados, examinar opções de facilitação ou dificuldade dos cálculos, atentar aos mecanismos que permitiram colaboração mais eficiente entre os integrantes de cada equipe de jogo, etc.

Ao dar início às perguntas desta segunda parte da avaliação, a professora enfatiza o interesse pessoal das crianças (o que gostou no jogo, o que não gostou), o envolvimento com a ludicidade da proposta, os comportamentos de colaboração, bem como o respeito ao próximo e às regras do jogo.

O detalhamento do aprendizado e a auto-avaliação das crianças são superficiais, devido ao tipo de perguntas da professora, como atesta o próximo excerto relativo ao diálogo entre Bel e um dos alunos ${ }^{72}$ :

(Ricardo) a gente precisou tirar uma conta...

(Bel) em qual? No de bolinhas (de gude)?

(Ricardo acena afirmativamente).

\footnotetext{
72 Vide 0 excerto à página 172.
} 
(Bel) se tivesse ficado com três contas e não duas, vocês sabiam (sic) responder?

(Ricardo) era número muito grande, não dava pra fazer de cabeça...

(Bel, para toda a classe) quem mais teve cartela com duas contas, ou mais contas?

O grupo de Ricardo criou um problema matemático com uso de numeral de quatro dígitos. No entanto, o nível de complexidade dos cálculos era incompatível com a condição de realizá-los, sobrepujando os conteúdos de ensino previstos para a série.

Pelo diálogo, o restante da classe não é capaz de identificar a qual problema o aluno está se referindo e, portanto, não há como as demais crianças participarem da formulação de outras hipóteses. A interlocução se atém à etapa de preparo das cartelas, quando o problema ainda não está terminado, sem pistas que auxiliem a reconhecê-lo depois de concluídas as alterações no enunciado. Além disso, no momento do jogo, todas as cartelas estavam agregadas, sem identificação do grupo que as elaborou, e a atenção estava voltada à resolução de cada problema em particular, impossibilitando às crianças se lembrarem dos enunciados mais tarde. A interação, dessa forma, é restrita e a discussão se limita ao formato do problema, não atingindo os aspectos mais complexos e relevantes da aprendizagem.

A dinâmica avaliativa perdura na forma indicada. 0 interesse da classe diminui gradativamente. Várias vezes é preciso impor regras de comportamento. 0 comportamento dos alunos demonstra que no formato em que a avaliação é encaminhada carece de sentido para que eles mantenham a atenção. Contudo, Bel parece não se dar conta do fato.

O desenvolvimento de competências e a consolidação de saberes a partir do jogo prescindem de uma gerência da etapa de avaliação que articule e sistematize os processos metacognitivos dos educandos.

Pressupomos que o comportamento dos alunos, na continuidade da avaliação, seria bastante distinto se tivessem participado de sua configuração, não apenas porque se sentiriam igualmente responsáveis por realizá-la, mas porque poderiam contribuir com idéias que facilitariam as trocas de experiências, aspecto essencial para mantê-los envolvidos.

Quanto ao aprendizado, o significado de "fazer de cabeça" poderia ser explorado. 0 objetivo educativo do jogo não impediria o cálculo mental, ou seja, não seria essa a razão principal para rever o enunciado. A discussão mais frutífera seria a de avaliar as distinções entre produzir problemas mais difíceis pela quantia de cálculos ou pelos valores numéricos.

A prática ludo-educativa ainda se apresenta de maneira experimental, no início de um processo longo, para ser plenamente integrada. Por isso, estimular, provocar e gerenciar a reflexão discente - constituída pela avaliação do que saber, como saber, para que saber, o 
que é preciso ou desejado saber (orientar os alunos para que eles mesmos atuem de forma metacognitiva) - demanda habilidades a serem desenvolvidas.

Lia também se empenha para constituir o diálogo avaliativo com a turma. No entanto, os questionamentos da professora têm o objetivo exclusivo de averiguar o acerto das respostas às indagações das cartelas. Lia lê em voz alta o conteúdo de algumas cartelas e interroga à classe, sem especificar um aluno ou grupo, visando se certificar da adequação de conhecimentos da turma. Como no caso de Bel, observamos que Lia modifica a forma de conduzir a avaliação, pois, agora, esta etapa não tem apenas a finalidade de valorizar 0 jogo, mas de coletar informações sobre o desempenho dos alunos.

Dois excertos, de fases distintas do projeto formativo, permitem conhecermos os núcleos significativos de exemplificações, observações e análises de Lia em relação à aprendizagem dos alunos.

O primeiro se reporta ao décimo quinto encontro (terceira fase). Esta é a primeira vez que, de fato, o grupo formativo assume o planejamento de uma atividade lúdica - o jogo de Percurso.

Logo que o encontro se inicia, a formadora solicita que as professoras teçam impressões sobre o processo de aprendizagem de seus alunos e explicitem relações com conteúdos que poderão ser vinculados à próxima experiência de jogo, visando embasar a conformação do jogo aos propósitos de ensino de cada turma/série. Essas orientações permitem às professoras tratar de vários assuntos. Remetem-se tanto a propósitos curriculares quanto a facetas do perfil da turma ou de um aluno. Nesse contexto, Lia faz o seguinte apontamento sobre uma das crianças de sua classe:

Eu percebi que, quando tá jogando, o Kleber... Sabe? Aquele pequenininho que senta na frente? Então, ele é esforçado, né?! Mas tem dificuldade de retenção. Acho que é problema de memória. $\mathrm{Na}$ aula, vai fazendo as coisas, mas chega no final da aula e já não sabe, erra nas perguntas... Ou, no dia seguinte, aquilo que fez ontem, não sabe mais fazer hoje... Só que... na hora do jogo, ele conseguiu!! E os colegas ficaram parados, esperando eu dizer que ele tinha errado. Mas ficaram surpresos, porque ele acertou! Deram um voto de confiança nele (sic). Depois, das outras vezes que falava, o grupinho dele já acreditava mais que ele podia acertar. E ele acertou mesmo bastante coisa...

No segundo fragmento, relativo ao décimo oitavo encontro, Lia enfoca o mesmo aluno. Dessa vez, estamos todas envolvidas com a avaliação da última experiência realizada (Jogo de Tapão).

Eu estava pensando no Kleber... Ele parece que tem uma dificuldade de juntar 'alhos com bugalhos'. Você viu, né? (esperando confirmação da 
formadora que, inversamente, pede novas explicações)... Ah, ele tem muita dificuldade. Não consegue entender... Tem lá... uma cartela (do Tapão)... por exemplo, o problema: 'tem cinco maçãs. Cada uma custa um real. Quanto é o total?'. Pronto... Ele já começa a falar da maçã, da banana... Ele é capaz de inventar uma história inteira, sem nexo nenhum com o conteúdo daquilo que precisa fazer...

E um pouco mais adiante, Lia completa sua avaliação:

(ele) é assim: "sabe aquele coiso que eu esqueci, que eu não lembro..." o que é isso?! Tem que fazer na base do 'saca-rolha'... Eu vou puxando, fazendo mil perguntas. Vendo o que ele confirma comigo. Quando faz cara de "do que você tá falando?" dá pra ver que é aí que eu tenho que explicar mesmo, pra ele ver que sabe... mas não passa nem cinco minutos, lá vem ele perguntando a mesma coisa, só que pro exercício seguinte.

Lia parece não se dar conta da contradição exposta em sua fala. 0 aluno precisaria de constante acompanhamento para ser capaz de utilizar um conhecimento 'aprendido', ou seja, auxílio na construção de redes de relações entre diferentes conhecimentos. No primeiro exemplo, a professora exalta o desempenho dele em jogo, quando participa ativamente. Por um momento, "deram um voto de confiança" a ele, conquistando um status distinto daquele que lhe é atribuído.

Nas duas ocasiões, a análise de Lia é pautada na descrição. Preocupada, a professora procura compreender as razões do que ocorre com a aprendizagem dessa criança. Seleciona observações da experiência concreta, inferindo que deva se tratar de uma dificuldade em memorizar. Da maneira como o caso é apresentado, pressupõe-se que a solução do problema central não é de foro educativo. A dificuldade para reter informações distancia-se do escopo pedagógico e, portanto, do campo de ação docente.

Apesar dessas análises sobre o processo de aprendizagem discente, Lia ascende a interpretações favoráveis quanto à capacidade do jogo de promover simetria nas relações entre alunos. Aliás, tanto para ela como para Bel, essa é uma qualidade inerente à atividade lúdica, embora não vejam como um aspecto constitutivo de suas próprias interações com a classe.

Assim, na avaliação do projeto, Lia considera que os alunos em geral, mesmo os que, na entrevista inicial eram vistos como "apáticos", "difíceis de saber o que estão pensando", nas situações de jogo, tornaram-se "muito falantes". Para essa professora, tal fato justifica o uso de jogos, afinal

a criança consegue mostrar aspectos de sua personalidade $e$ conhecimentos diferentes daqueles que apresenta em tarefas escritas. Eu vi, na prática, como o jogo é atrativo, a sua motivação, o 
envolvimento que causa. É por isso que os alunos se mostram mais. (entrevista final)

Ainda sobre o caráter interativo da atividade lúdica, Lia pondera que o jogo permite ao educador

atender realmente as crianças com maior dificuldade, especialmente numa sala tão numerosa. A inclusão dentro dessa realidade, de sala com grande número de alunos e sem o apoio efetivo de especialista em cada escola, é mais democrática quando eles estão envolvidos no jogo, parece que deixam de se importar com disputas de quem sabe mais, de quem é melhor ou pior. (entrevista final)

Ao tecerem suas impressões sobre a função interativa do jogo, as professoras têm percepções semelhantes sobre o caráter 'democrático' do jogo. De acordo com a análise de Bel:

a atividade lúdica coloca o aluno em contato com uma situação nova ou desafiadora, com o apoio de materiais concretos ou brincadeiras. É uma atividade descontraída, onde o aluno aprende brincando com os colegas. Ninguém precisa se exibir, porque estão todos juntos no mesmo barco. $O$ aluno, especialmente aquele que em geral fica mais quieto, no canto, fica mais alegre, disposto, participativo. Mas eu acho que a mudança maior é dos que costumam discriminar los outros). Eles colaboram com os colegas, fica mais solidário, mais responsável. (entrevista final)

$\mathrm{Na}$ concepção das professoras, o jogo propicia integração entre os alunos, bem como atitudes colaborativas. No entanto, a intervenção do educador, sobretudo a que venha respaldar práticas mais simétricas de avaliação das aprendizagens, é um assunto ignorado. Trata-se de um aspecto complexo e essencial à prática ludo-educativa que, em razão de alterar significativamente as relações entre docente e educando, necessita ser melhor e mais tematizado, discutido, elaborado para, futuramente, fazer parte de reflexões sobre a prática pedagógica dessas professoras.

\section{c) Reunião pós-atividade}

Diferentemente dos outros encontros de avaliação, em que a discussão não seguiu um roteiro prévio, a formadora insere um Instrumento de Observação em que os princípios ludoeducativos são dispostos em vinte e seis itens $^{73}$, com a finalidade de sistematizar a

\footnotetext{
73 Os conceitos abordados foram: a) relação entre saberes escolares e outros, informais e não escolarizados; b) regras: regulação do comportamento pelo outro e auto-regulação; c) interação: envolvimento com objetos lúdicos e participação colaborativa em equipe e com toda a classe; d) estratégias cognitivas: soluções para cumprir com o objetivo educativo da atividade; e) generalização e descontextualização de conceitos; f) metacognição: avaliação das próprias competências; g) autoconceito e auto-estima; h) registros e comunicação do processo de realização da atividade; i) atribuição de significados aos objetos e às ações lúdicas.
} 
investigação das professoras sobre aprendizagem e desenvolvimento dos alunos em situação lúdica de ensino.

Cada item é composto da exposição do conceito e de uma explicação sucinta. Abaixo do enunciado, cinco situações são apresentadas para que a professora assinale aquela que considera mais pertinente, considerando um de seus alunos como referência. $O$ instrumento também é constituído de itens específicos sobre a atividade, possibilitando julgar como foi experienciada e em que medida favoreceu o comportamento autônomo e a aprendizagem. A seguir, apresentamos um exemplo:

13. Participação colaborativa do aluno com os colegas de sua equipe

1. não interage, mantendo-se a maior parte do tempo isolado

2. aguarda iniciativa dos colegas, imitando-os e sem se expressar verbalmente

3. acompanha o que colegas fazem e solicita-lhes ajuda

4. buscando ser solícito com os colegas, faz por eles e corrige seus erros

5. oferece ajuda espontaneamente, sugere alternativas, explica, fornece dicas ou demonstrações

OBS: A primeira alternativa expressa desinteresse ou insegurança. $O$ nível 2 indica que a criança participa, mesmo passivamente. O nível 3 refere-se ao pedido de colaboração, ou seja, a criança não colabora, mas promove a colaboração dos demais. No grau 4, há algum tipo de ajuda aos colegas, mas realizada de maneira não colaborativa. No nível 5, o aluno colabora, sem impedir seu colega de solucionar o desafio.

Todo o debate sobre a experiência com o Tapão é desenvolvido a partir das respostas ao elenco de questões. Com uma cópia à mão, as professoras acompanham as explicações iniciais da formadora e, posteriormente, iniciam o preenchimento. Sempre que as informações do enunciado não são suficientes, solicitam novas explicações, ampliando nosso campo de visão quanto ao que conhecem e como interpretam os conceitos, gerando discussões reflexivas no grupo.

Para facilitar o preenchimento, todas concordam com a proposta de uma das participantes para que um perfil de aluno seja utilizado como referência, um aluno que,

além da gente ter observado na situação lúdica, tem um perfil. Por exemplo, o aluno que costuma deixar a gente 'com a pulga atrás da orelha' pra entender como ele pensa... Porque tem uns alunos que fazem a gente 'matutar mil coisas'. Por que será que aprende ou não aprende? Como atingir (gerar aprendizagem)? Tá me entendendo?

Até o vigésimo terceiro item, todas assinalam suas respostas, refletindo sobre os conceitos e os relacionando a seus alunos. Contudo, nos seguintes - por serem específicos à etapa de avaliação discente sobre o jogo - uma substancial diferença surge no grupo: ao contrário de Bel, as demais realizaram o que chamaram de "um fechamento" oral, 
constituído pela apreciação (do que gostou, do que não gostou) e/ou pela verificação do desempenho. Somente na classe de Bel o exame das aprendizagens se efetivou. Assim, ela se torna a única cujas respostas a esse último bloco de itens são de um nível mais elevado.

Vejamos o exemplo de um dos itens e a subseqüente discussão no grupo formativo:

24. Na forma como foi avaliada, a atividade determinou a elaboração de registros pelos alunos

1. não foi requerido nenhum registro

2. possibilitou uso de registros, mas sem se definir sua finalidade

3. uso funcional de registros foi requerido, mas não foi definida sua especificidade

4. o uso funcional de registros foi específico e organizado pela professora

5. o registro funcional e específico foi definido com a participação dos alunos

OBS: a atividade lúdica em si não é suficiente para a aprendizagem. Os registros após o término do jogo são meios de organizar e sistematizar o aprendizado, propiciando que os alunos reelaborem idéias e modos de agir. O registro auxilia o aluno a desenvolver a metacognição. Ter de representar o que foi realizado (sob a forma de desenhos, textos, gráficos, tabelas, etc) contribui para sua auto-avaliação. Fazer registros eficientes é um processo, altera-se conforme o aluno tem oportunidade de realizá-los. Quanto mais apropriado é o uso do registro, mais o aluno se mostra capaz de criar mecanismos para que ele mesmo, sem controle do professor, compreenda e expresse o seu processo de raciocínio. Saber para que servem e como devem ser utilizados os registros e, além disso, colaborar para defini-los demonstra alto grau de autonomia e de organização mental (nível 5).

Enquanto suas colegas assinalam a primeira alternativa, Bel considera que a quarta corresponde ao que ocorreu com sua turma. Ou seja, o registro funcional foi realizado, embora tenha sido definido sem a participação das crianças, aspecto este que confirma a inexistência de interações pelas quais os alunos sejam incentivados a colaborar com 0 encaminhamento da atividade.

Solicitada a descrever às colegas a experiência de avaliação discente do jogo, Bel inicia dizendo:

A gente fez assim... A gente conversou, eles foram falando quais as coisas bacanas da atividade, pra que serviu e tal... E se teve coisas pra melhorar no jogo... Eu anotei na lousa... Mas eu pedi pra escrever também no caderno as regras e as instruções, pra não esquecer. Depois, a gente foi conversando sobre a criação dos problemas, só que acabou ficando meio disperso...

A discussão a partir das descrições de Bel se prolongam. A cada detalhe que ela acrescenta, seguem novos comentários e questões das demais, demonstrando que todas passam a reconsiderar a função desempenhada por este procedimento.

A própria Bel reavalia o trabalho realizado. Embora já houvesse vivenciado "um fechamento depois que o jogo acabou", a professora considera que o modo como se deu 
essa etapa foi bastante distinto, sendo preciso "aperfeiçoar, porque daria pra ter aproveitado melhor a conversa, não ficar com conversa centrada num grupinho, e os outros sem acompanhar", o que levou a desmotivar os alunos. Desse modo, a análise da professora, formulada em colaboração com as colegas, envolve uma compreensão mais apurada do comportamento da classe. Ainda assim, a reflexão sobre a configuração da proposta permanece centrada na figura docente, sem que Bel e as demais professoras questionem-se sobre o que a quinta alternativa do item designa.

Dando prosseguimento às discussões, Lia observa que

de qualquer modo, é bom que a avaliação do jogo aconteça logo depois que termina, porque eles ficam concentrados e serve para colocar um ritmo mais tranqüilo... Senão, contrasta demais! Numa hora, estão todos em grupo jogando, animadíssimos! Ninguém vai querer sentar, depois, e ficar quieto fazendo os outros exercícios.

A professora valoriza a avaliação após o jogo, fator este imprescindível na efetiva contribuição da ludo-educação ao ensino. Sob seu ponto de vista, essa etapa não tem apenas a função apreciativa. Contudo, ela destaca o benefício comportamental - o "ritmo mais tranqüilo" que facilite retomar atividades não lúdicas - deixando de mencionar as oportunidades de aprendizagem e de desenvolvimento que a avaliação poderia instaurar.

A análise de Bel, logo a seguir, demonstra uma percepção diferente:

acho importante colocar que, pela avaliação, os alunos levantaram os pontos positivos e negativos da atividade... Os negativos, eu procurei fazer os alunos discutirem e eles foram revendo... Isso aconteceu mais com a organização das equipes e a conversa... que extrapola, não a conversa que faz parte mesmo. Neste sentido, acho que o jogo também serviu pros alunos refletirem. Acho que, neste sentido, foi bem importante!

Bel analisa que o jogo e, mais especificamente sua avaliação, proporciona a metacognição, embora circunscrita pelo comportamento na atividade sem menção ao conhecimento escolar.

Em seguida, orgulhosa, a professora expõe à mesa diversas cartelas do jogo elaboradas pelos alunos, enfatizando a criatividade com que formularam as situações-problema.

De início, as cartelas conotam um emblema dos feitos realizados por sua turma. Aos poucos, a discussão se envereda para qualificar esse material também como um instrumento de observação e, mais importante, não derivado de uma ação da formadora, mas decorrente da iniciativa do grupo.

Ao notar a valorização atribuída às cartelas, Lia menciona que também guardou as produzidas por seus alunos, explicitando que uma maneira nova de significar a produção 
discente está se construindo, tornando-se possível "acreditar mais na capacidade dos alunos".

As reflexões das professoras encaminham-se para compreender conceitos de ludoeducação e relacioná-los à sua atuação pedagógica. Em níveis distintos, formulam idéias, algumas mais precisas, sistematizadas e generalizadas; outras, fragmentárias e fortemente delimitadas pelo contexto da experiência concreta.

É fato que a conceituação exige um grau de complexidade incompatível com o tempo em que se deu o projeto de formação. Por isso, não surpreende o fato de Lia e Bel apenas tecerem algumas noções conceituais, ainda não plenamente integradas umas às outras, lacunares e, em alguns casos, contraditórias com os princípios da ludo-educação.

Para tratarmos desse tema, o longo excerto a seguir ilustra, a partir de um dos itens do instrumento ${ }^{74}$, como as professoras abordam aspectos centrais da ludo-educação e constroem suas interpretações.

(Lia) Aquilo que você disse... já faz um tempão, da quantidade de regras... ter poucas regras de início pra depois... ir aumentando pro jogo ficar mais difícil... Eu queria dar uma retomada nisso porque esse jogo (Tapão) já tem bastante regra. É diferente do (História do) Teatro... Agora, não. Agora... com o Percurso e o Tapão, eu sinto que é uma coisa mais consistente, porque a gente tem toda uma previsão. Quando a gente for fazer por conta, não é melhor ir direto nesses? Parece que dá mais certo pra visualizar essa observação...

(Alê) Acho que você trouxe uma questão importante, Lia. A escolha do tipo de jogo tem a ver com decidir facilitar ou dificultar o jogo em si? Em que situação vai pra uma ou outra direção? Como decidir?... Aliás, decidir... em função da dinâmica da turma, dos conteúdos que estão envolvidos, de quanto os alunos estão, ou não estão, acostumados com essa rotina de aprendizagem lúdica...

(Bel) ... Em cima do que a Lia tinha falado, essas experiências são bem diferentes. Eu não saberia dizer se é preferível um jogo como o do Teatro ou como o Tapão, um de menos regras e outro todo estruturado...

(Alê) ...Quer dizer: quais os critérios que estão por trás das decisões sobre o tipo de jogo? Como e quando usar um jogo? E, mais importante: pra quê, né? E de que forma vai ser apresentado? Então, o que a gente tá questionando tem a ver com uma das coisas centrais da prática ludo-educativa. Caso contrário, o risco de ficar preso a determinadas fórmulas acaba sendo imenso! E o que é pior: não é o problema da 'fórmula' em si; o que é mais complicado é que acabaria nos amordaçando a um determinado jeito de compreender o jogo para aprendizagem.

(Bel) E que critérios pode ser? Observar? Garantir a observação é um

$74 \mathrm{O}$ enunciado do $4^{\circ}$ item é: "Na atividade proposta: grau de complexidade das regras que envolvem sua execução", tendo como alternativas desde a inexistência de regras até a configuração do jogo por um conjunto complexo de regras. 
deles?

(Lia) Eu estou começando a 'pegar o jeitão' do que a gente fez aqui... (Antes), a gente não tinha condição de observar na mesma hora que o jogo está acontecendo. Só agora que está dando pra fazer pelo exercício no protocolo (Instrumento de Observação). Então, é uma coisa lenta. Demora para juntar: fazer o jogo e ir acompanhando a aprendizagem dos alunos... Mas não impede de já ir testando, como a gente acabou fazendo... A observação acabou sendo feita depois, quando a gente conversou sobre os trechos que a Alê passou no vídeo (refere-se à décima segunda reunião). Aí, sim, nós tivemos tempo pra observar com mais calma, de lembrar de como foi, de 'palpitar' pra melhorar... Igual o que a gente tá fazendo pelo instrumento...

(Bel) Eu fiz a pergunta porque... é justamente pra não deixar (a observação) pra depois, sempre. Porque se você observa... Sei lá... por exemplo... como aconteceu com um grupo da minha sala. Eles estavam criando os problemas sem fazer as contas porque não tinham entendido que tinha que ter cartela de problema e cartela de resposta. Se eu não tivesse observado isso, ali, na hora, só quando o jogo estivesse pra começar que iam ver que ainda faltava resolver os problemas pra passar nas cartelas de resposta. Então, tem umas coisas de observação que precisam acontecer (de) imediato. Por isso que eu tô insistindo na idéia de preferir os jogos mais regrados. Porque, no do Teatro, eu não sei como poderia fazer essa observação. Agora, é claro, né!!! Eu concordo totalmente que não basta essas coisas mais pontuais. Se a gente sempre se reunir pra discutir o que andou observando, tem mais chance de ter uma dica daqui, uma idéia dali, e... na hora (em) que o jogo for acontecer de novo, sai melhor. É como a gente fez agora pra falar de uma coisa que aconteceu na minha turma que eu nem tinha achado importante antes...

(Alê) .... experiência com diferentes tipos de jogos, uns mais voltados pro imaginário, com menos regras e outros, bem mais regrados, serve pra que a gente tenha 'cartas na manga' dependendo da situação, daquilo que os alunos vão estar aprendendo. Querem um exemplo (em tom de gracejo)?

(várias professoras) "Claro, né, Alê?!", "Eu já tava pra pedir um..."

(Alê) Lembram de uma reunião, quando a gente falou de criação de histórias pelos alunos... Que vocês até levantaram o problema de falta de criatividade na produção de textos... Que parece que os alunos só copiam... Vamos imaginar de trabalhar isso com um jogo. Qual ficaria mais apropriado pra observar a aprendizagem, quer dizer: observar a criação de idéias: o do Teatro ou o do Tapão?

(Bel) Ah!!! Entendi!!! Tá certo... Teria que ser uma coisa mais de teatro, né? Porque, pra construir a história, não pode ficar preso a muita regra. Tem que ser uma coisa mais de imaginação. É como aconteceu na sala! Teve aluno que escreveu a historinha nos desenhos que eu pedi pra eles fazerem depois que (o jogo) terminou ${ }^{75}$. Daria... eu tô achando agora, viu?! Não sei se vale... Mas, não só corrigir a ortografia... Mas pra observar a interpretação de texto, já que eles

${ }^{75}$ Alguns exemplos foram apresentados quando abordamos a avaliação do jogo de História de Teatro, à página 175. 
As duas professoras abordam aspectos essenciais da reflexão. Refletir durante e após a prática são fatores imprescindíveis e interdependentes. Enquanto a investigação posterior fornece elementos para compreender o que se passou e antecipar a prática futura (incluindo "quando for fazer por conta" - após o projeto), o exame no acontecer da atividade qualifica a mediação, interferindo diretamente na forma como a ação docente amplia e/ou aprofunda as aprendizagens em processo.

Lia salienta que o próprio processo formativo "é uma coisa lenta", inexoravelmente. Reconhece, porém, conquistas importantes em direção à reflexão ludo-educativa, referindose a uma das questões centrais do uso do jogo como mediador do ensino: observar faz parte da atuação docente, um observar prospectivo, decorrente da compreensão sobre a própria prática. É preciso "começar a pegar o jeitão". Deve-se definir o que observar, como fazê-lo e para quê, ou seja, não se trata de um mecanismo ou uma técnica a ser implementada. Para ser incorporada ao saber-fazer profissional, é preciso que a observação seja experienciada e compreendida conceitualmente.

Porém, no episódio, não se explicita como a professora definiria o conceito 'observar'. Apesar disso, ao colocar o assunto em pauta, a professora qualifica a reunião como um espaço interativo do processo reflexivo e redimensiona vivências anteriores da proposta formativa. É intrínseco à profissão assumir as incertezas lado a lado com a experimentação; 'ir testando', não de forma inconsciente e aventureira, mas refletida.

Bel também reconhece a importância da observação e demonstra compreender seu significado na prática educativa. Durante a conversa, especifica seus questionamentos. Relacionando dois conceitos - observar (como instrumental para a mediação da aprendizagem) e definir critérios para inserção do jogo educativo - procura abstrair novas idéias e encontrar meios para colocá-las em prática.

Num primeiro momento, ao avaliar que a observação é imprescindível na atuação docente, Bel tende a privilegiar os jogos regrados em detrimento dos que têm predomínio de situação imaginária, hipotetizando que apenas o primeiro tipo oferece condição para acompanhar a ação discente. Assim, jogos como o de História do Teatro não poderiam beneficiar o processo de ensino-aprendizagem tanto quanto os do tipo do Tapão, até porque apenas nestes seria viável intervir em função do que se observa.

No decorrer do debate, essa visão se altera. Bel principia uma compreensão mais generalizada sobre o conceito de observação, redimensionando o papel dos jogos com predomínio do imaginário. Em decorrência, torna-se possível à professora sugerir um meio para que a observação se concretize como instrumento regulador da mediação pedagógica, 
independentemente do tipo de jogo.

Os contrastes entre as duas professoras continuam existindo. O mais importante, porém, é que ambas empreendem novas aprendizagens e progridem em seu desenvolvimento, mesmo que em níveis distintos. A forma como atuam é um dos principais aspectos para compreendermos seu percurso de desenvolvimento. Exemplos, indagações, observações, análises e soluções aos problemas são tratados de maneiras distintas, sobretudo pela freqüência com que se apresentam nas reflexões das duas educadoras.

No trecho episódico apresentado acima, teríamos alguns exemplos que, de certo modo, retratam o que observamos na trajetória formativa. Lia inicia observando, o que contribui para que Bel formule indagações. Na seqüência ("eu estou começando a 'pegar o jeitão'"...), Lia expõe novas observações, pelas quais analisa que "demora para juntar: fazer o jogo e ir acompanhando a aprendizagem dos alunos", finalizando com um exemplo. Considerando que seja necessário explicar melhor seu questionamento, Bel retoma a palavra, exemplificando. Em seguida, também observa que "tem umas coisas de observação que precisam acontecer de imediato", o que a leva a analisar que seja preferível "os jogos mais regrados", reafirmando seu questionamento e analisando o que significa a observação realizada a posteriori.

0 excerto finaliza com um redimensionamento de Bel sobre a relação entre os tipos de jogos e o instrumental da observação para sua prática, apresentando uma solução de como exercê-la, inclusive em jogos com predomínio da situação imaginária.

A exemplificação e a observação, seguidas de análise, são bastante comuns no discurso de Lia. No caso de Bel, a indagação quase sempre é central em suas explanações, havendo uma expressiva freqüência de sugestões para resolver problemas. De modo algum esses dados significam ausência de diferentes maneiras de aprender, nos dois casos estudados. Lia privilegia a exemplificação e a observação, mas não deixa de questionar e apresentar soluções, sendo isso igualmente verdadeiro para Bel. Todavia, essas diferenças explicitam quais são as maneiras privilegiadas de cada docente vivenciar a trajetória formativa.

Por fim, na percepção das professoras, o instrumento de observação cumpre seu propósito formativo ao proporcionar a abordagem dos conceitos de ludo-educação e, sobretudo, correlacioná-los à experiência lúdica. Nas palavras de Lia:

Sabe, Alê. Eu tava vendo... o protocolo de observação é muito interessante. Dá mais chão pra ver como caminhar em seguida. Isso a gente nunca fez... acaba tendo um dado mais concreto pra poder se localizar em relação a cada aluno... é muito interessante! Eu queria saber se você teria algum material pra indicar no sentido de fazer mais isso, uma coisa mais organizada. 
Conforme a professora anuncia, além de ser útil à avaliação da atividade ludo-educativa, o instrumento aguça seu interesse em respaldar novas aprendizagens a partir de referenciais teórico-metodológicos. Essa informação, aliada a diversas outras sobre seu percurso formativo, oportuniza hipotetizarmos que suas inúmeras observações têm o propósito de sistematizar conceitos. Embora não tenham as qualidades necessárias para serem consideradas conceituações, pois Ihes faltam características como abstrações generalizadas e descontextualizadas, as observações de Lia estiveram todo o tempo cumprindo o papel de se ajustar à necessidade explicitada em seu comentário: alinhavar as experiências vivenciadas às oportunidades de estudo sistemático da teorização que as embasa.

$\mathrm{Na}$ reunião seguinte (19â), ao ser retomada a discussão sobre o instrumento, outros assuntos complementam o exame das professoras sobre sua prática profissional. Um deles é a relação da escola com os familiares. Segundo Bel,

a função do educador não se restringe à sala de aula. Tem que chegar com os tentáculos até a casa do aluno, porque a mãe nem sempre entende a importância de acompanhar o que acontece com seu filho na escola. Às vezes, é até por causa de medo... por causa da baixa escolaridade... Não saber como ajudar... Tem mãe que fica orgulhosa que o filho sabe mais que ela. Mas tem mãe que fica chateada, não vê que isso é motivo de orgulho.

Em seguida, Lia diz:

o Roberto, a mãe dele é analfabeta, o que é um complicador. Agora, por exemplo, o José, ele já tem um acompanhamento em casa. Ele tem uma letra muito feia, um traçado feio, mas a gente percebe que é inteligente. Tanto é que ele está alfabético... Só que isso não (se) reflete na matemática. Ele tem dificuldade nos números, o que vem antes e o que vem depois. Eu tô pensando em chamar a mãe pra conversar sobre isso.

Bel inspira-se numa metáfora para representar como concebe a função do educador. A professora não se reporta a um caso em particular; sintetiza duas situações opostas, formulando sua análise. Mediante exemplificações, Lia respalda suas observações quanto ao apoio familiar e à análise acerca de um aluno.

Não faz parte do escopo desse estudo pesquisar as representações que as professoras têm construídas em sua profissionalidade. Contudo, não ignoramos que os modos de conceberem ensino, educação e aprendizagem estejam estreitamente implicados no potencial de desenvolvimento promovido pelo projeto de formação, bem como outros fatores cuja magnititude não foi ignorada: diferenças entre as séries para as quais lecionam e de experiência profissional.

A última fase do projeto traz mudanças consideráveis na ação e na reflexão das duas 
professoras. Lia e Bel definem a estrutura da atividade lúdica e prevêem sua realização, antecipando problemas e buscando solucioná-los. Seus questionamentos, mesmo quando focalizam aspectos específicos para e da execução, evidenciam a valorização do jogo como instrumento para promover a autonomia das crianças. Aos poucos - e, em alguns casos, mais no plano discursivo do que no da ação - ambas revelam que algumas noções abstratas sobre a ludo-educação passam a se integrar à sua compreensão do processo de ensino.

As distinções entre as professoras se alargam, especialmente pelo comportamento de Bel. As mediações pedagógicas durante a atividade e a realização da avaliação junto aos alunos são os dois aspectos que mais a aproximam de tornar rotineiro o jogo como mediador. Ao instruir os alunos, a professora insere alguns elementos não previstos no planejamento, demonstrando uma crescente autonomia para adequar a proposta lúdica à situação de ensino.

Da análise dos processos cognitivos de Bel, destacam-se a observação dos alunos durante a atividade e as problematizações que favorecem a atitude decisória discente.

Há elementos a serem sistematizados e descontextualizados. Por isso, os avanços de Bel são notórios - se tomarmos cada aspecto isoladamente - e incipientes - quando abordados segundo níveis de diferenciação e integração de seu desenvolvimento. A avaliação do jogo com as crianças, apesar de ser realizada seguindo parâmetros ludo-educativos, ou seja, objetivando aprofundar a aprendizagem discente, da maneira como é orientada pela professora os apontamentos dos alunos são pouco aproveitados para estabelecer generalizações importantes, como a de construir parâmetros reguladores da atitude colaborativa. Especialmente em relação à aprendizagem de conteúdos escolares, a professora demonstra dificuldade para dialogar com toda a turma, fixando-se na atenção individualizada, tornando inviável o exame metacognitivo das crianças, que acabam por se dispersar ao não terem claro o significado da avaliação.

Em relação às reuniões do grupo formativo, Lia é a principal fonte de exemplos. A narrativa detalhada de casos é benéfica à reflexão de todas as participantes. Todavia, a própria Lia explora pouco seus exemplos a fim de construir novas compreensões sobre o ensino e, em particular, sobre práticas pedagógicas que tenham o jogo como mediador. Suas observações e análises, embora freqüentes, qualificam-se num nível aquisitivo de apreensão da prática ludo-educativa.

A docente aborda recursos, materiais e procedimentos de confecção do jogo como fatores decisivos na consolidação de práticas ludo-educativas. Para ela, ter jogo previamente definido é uma prioridade. Por isso, concentra suas intervenções no momento de organização do cenário de aprendizagem. 
Exemplificar - isto é, referenciar-se no existente ou experienciado - é a forma preponderante para Lia refletir sobre a organização do cenário de aprendizagem, seja em relação aos recursos e procedimentos de jogo ou à caracterização de suas regras. Embora a professora acentue o valor do planejamento pedagógico, revela algumas distorções na operacionalização da atividade lúdica. O conteúdo das exemplificações demonstra que Lia tende a manter o controle e o direcionamento, da mesma maneira que age nas demais atividades pedagógicas. A falta de liberdade dos alunos na tomada de decisões é velada. Não se trata de coação. Na ânsia de dar conta dos problemas que podem surgir na ação lúdica, Lia se antecipa e toma como suas as tarefas mais significativas de elaboração dos objetos e procedimentos de jogo. Aos alunos, cabe jogar, sob controle de regras igualmente estruturadas, limitando sua autonomia e criatividade.

Sem indagar com freqüência, Lia formula suas hipóteses respaldada pelo conhecimento adquirido nos anos de experiência profissional, nas idéias consolidadas em sua profissionalidade pregressa. No entanto, muitas vezes, tais hipóteses contrastam com os princípios ludo-educativos, contribuindo pouco para que possa transformar sua atuação profissional, isto é, para que o jogo venha se consolidar como um dos mediadores de sua prática profissional, de modo sistemático, rotineiro e integrado.

\subsection{4 - Entrevistas final e de feedback}

A contradição faz parte do processo de desenvolvimento humano. Assim, é preciso análise apurada para que possamos observar as distinções mais sutis em processo, que servem de apoio para potencializar a aprendizagem de novos conhecimentos, construída reflexivamente. 0 conjunto de entrevistas realizadas logo após o término do projeto (finais) e quando nos reencontramos com as professoras para dialogar sobre o material produzido com base nas transcrições (feedback) tem uma vantagem em relação às outras fontes de dados: ao explicitarem como pensam, sem as interrupções que fazem parte de um espaço de debate, as professoras expõem novas informações que auxiliam na interpretação de seu percurso de desenvolvimento.

$\mathrm{Na}$ finalização desse capítulo, focalizaremos elementos dessas entrevistas, não abordados anteriormente, coordenando as contradições, os conhecimentos, as incertezas e as novas expectativas intrínsecos ao processo de desenvolvimento de Lia e Bel.

Para Lia, as reuniões tiveram papel essencial na construção de uma visão mais ampla da "inter-relação e convivência com pessoas que pensam diferente, a troca e o crescimento mútuo", embora saiba que essa inter-relação não é harmoniosa, havendo "momentos estressantes que permeiam as relações... (dando) insegurança em lidar com esses 
momentos".

Segundo ela, o projeto deu-lhe segurança para crer que o jogo promove atitudes importantes para a aprendizagem nos alunos, "estimula a curiosidade e a disposição para o novo". Por isso, a expansão da proposta beneficiaria o coletivo escolar, desde que a ludoeducação viesse a fazer parte das referências para a criação de "novos projetos, planejar atividades, promover situações de crescimento individual e coletivo".

Adicionalmente, conclui que a experiência com jogos sobrelevou sua posição de "ter os alunos como ponto de referência" para tomada de decisões, reflexões e construção de saberes da prática, mesmo quando "a gente não tem certeza onde vai chegar". Nesse sentido, considera que passos importantes foram dados através desta experiência formativa.

No começo, as expectativas foram muito altas. Eu ficava esperando você trazer os jogos, achava que você daria 'receitas' para utilizarmos em sala de aula. Eu pensava sempre num grande número de jogos e maior participação sua com alunos... Aos poucos, acho que fui 'entendendo' a dinâmica do trabalho. A sensibilização de nós, professores, para a importância dos jogos, as diferentes maneiras de se aproveitar um mesmo material e a busca de se colocar o jogo em sala de aula como rotina. O grande problema continua sendo o número excessivo de alunos. A intervenção do professor fica pequena tendo que dar conta de tantas crianças ao mesmo tempo. Mas talvez o jogo ajude até nisso, porque a gente pode ter um tempo mais livre, enquanto eles jogam. Eu acredito que foi bom pra amadurecermos, não ficar idealizando que vamos ter condições melhores de trabalho. Tem que tirar o máximo proveito de experiências como esta. Mas é um esforço pessoal. É arregaçar as mangas, planejar, preparar os materiais e tornar o jogo um direito à formação das crianças, e não um prêmio para quando sobrar tempo. (entrevista de feedback)

É compreensível que, diante de uma nova abordagem ou de um conhecimento distinto daquele que temos internalizado e da necessidade de transformá-lo em ação, a incerteza se alie à vontade de obter respostas prontas e únicas, mesmo reconhecendo que elas inexistam. Consciente disso, Lia aponta que é preciso começar do princípio: sensibilizar-se quanto à importância do jogo para a educação é o primeiro passo, com o qual advêm aspectos mais concretos, como fazer uso da versatilidade de materiais para transformá-los em objetos lúdicos e inseri-los na rotina escolar. A realidade impõe a condição de suplantar crenças e, sobretudo, superar obstáculos. Desse modo, o desenvolvimento se eleva: da sensibilização surge o amadurecimento. A professora não apenas aceita mudar; deseja retirar o máximo proveito de uma oportunidade de aprendizagem, disposta a 'arregaçar as mangas' a fim de que o significado da formação repercuta na qualidade de ensino.

Lia percebe ser insuficiente considerar o aluno elemento central da docência, sendo imprescindível um longo processo de (re)elaboração e (re)orientação da atuação profissional. 
Por isso, as contradições fazem parte dessa (des)construção da profissionalidade.

Embora enfatize o 'esforço pessoal' para torná-lo 'um direito à formação das crianças' e reconheça o valor da atuação discente autônoma, explicitando seu interesse por promovê-la, é razoável que a discrepância entre a proposta ludo-educativa e suas próprias convicções a impeça de descartar a necessidade de predição e controle do processo de ensinoaprendizagem.

Procurando se convencer de que precisa mudar, na entrevista de feedback Lia recorda-se de um dos encontros do grupo formativo, quando havia declarado que necessitava ser 'menos dominadora'. Comenta entusiasmada que o projeto permitiu dar-se conta disso, considerando surpreendente ter observado, na última das ocasiões de inserção de atividade ludo-educativa que, sem sua intervenção diretiva, houve uma qualidade das produções dos alunos superior às suas expectativas.

Para nossa própria formação, a atitude de Lia é um grande aprendizado. Mesmo quando é impossível reconhecer as contradições ou quando suas reflexões aglutinam idéias opostas, a educadora mantém o empenho por se emancipar, sempre.

Com relação à avaliação da experiência formativa, Lia destaca que tenha propiciado, não apenas a ela, mas a todo o grupo de participantes, voltarem a atenção para "aquelas brincadeiras que parecem só servir pra divertir, mas podem ser prazerosas e ter o objetivo de ensinar algum conteúdo". Entretanto, ao nos reencontrarmos no ano seguinte, ela informa que se tornou raro realizar atividades lúdicas com a mesma estrutura com que foram experienciadas. Apesar disso, passou a se valer de brincadeiras que possibilitam aos alunos "se manterem envolvidos" e pondera que, em função dessas atividades, passou "a ganhar beijo de todo mundo, no final da aula", sublinhando a relação entre ludicidade e incremento da expressão de afetos entre ela e seus alunos. A inexistência de jogos educativos é justificada pela professora a partir de dois motivos inter-relacionados: ter de lidar com classes numerosas e ser prioritário contar com um auxiliar em sala.

O grande intervalo de experiência profissional que separa Lia de Bel permite àquela ampla desenvoltura e dinamismo na forma como se coloca nas reuniões e se auto-avalia. Bel valoriza e se espelha nessas qualidades para desenvolver suas competências no que se refere ao ensino lúdico.

$\mathrm{Na}$ entrevista realizada nove meses após o término do projeto, Bel não esconde seu contentamento por ter incluído, desde o planejamento pedagógico, no início do ano letivo de 2003, séries de atividades lúdicas dirigidas para a aprendizagem. “Agora sim, está mais dentro do dia-a-dia", diz ela, explicando que passou a inserir, com intervalos de aproximadamente um mês, três aulas em que os alunos preparam o jogo, jogam e avaliam a 
atividade.

Em relação ao valor do jogo, Bel sublinha que é preciso integrá-lo ao processo de ensino a fim de se evitar que seja transformado num apêndice que, fatalmente, deixará de existir na rotina escolar. Assim,

- lúdico ajuda a levar o aprendizado para situações concretas, sem descuidar da parte do raciocínio abstrato. Precisa associar um com o outro. O lúdico ajuda a desafiar as crianças a novas situações porque é motivador por natureza. Por isso, eu acho que ele também ajuda (os alunos) a desenvolver habilidades e posturas para a vida. (entrevista final)

Associar "situações concretas" com o "raciocínio abstrato" é compreender a vinculação existente entre as funções lúdica e educativa do jogo - para inseri-lo na escola, é necessário concebê-lo como atividade ludo-educativa. Ao representá-lo dessa maneira, Bel explicita uma importante transformação entre o início e o término da proposta formativa. Lembremos que, junto a suas colegas, a professora vivenciou situações em que esta interdependência não era tão evidente. Assim que propusemos uma alteração no curso do projeto, indicando a necessidade de realizar o jogo de História do Teatro com os alunos, a dicotomização se mostrava tão acentuada que impunha considerar a atividade impraticável por parecer destituída de qualquer benefício ao processo de ensino-aprendizagem.

No desenvolvimento profissional de Bel, as mudanças têm uma qualificação mais próxima do objetivo central do projeto. Segundo seu ponto de vista, jogos e brincadeiras são instrumentais úteis para a aprendizagem, analisando que:

\footnotetext{
o projeto foi muito bom e especialmente o interesse das crianças me surpreendeu...

Um ponto que eu queria ressaltar como positivo e que me surpreendeu muito foi a participação e a integração dos grupos para confeccionar o jogo... Foi importante ver o jogo como uma nova metodologia.

Enfim, Alê, espero que o projeto tenha sido valioso também para a sua pesquisa. (entrevista final)
}

As surpresas de Bel equivalem a descobertas acerca dos alunos: seu potencial criativo, a ação colaborada e o envolvimento com a atividade. Esses fatores colocam o jogo na posição de constituinte de uma metodologia de ensino.

De forma mais profunda, essas idéias são retomadas por Bel na entrevista de feedback:

o que fez a maior diferença pra mim foi que abriu um espaço para reflexão da minha própria prática, onde acabei de uma maneira ou outra construindo o meu modo de pensar sobre a questão dos jogos na sala de aula. Eu tenho quase certeza que se fosse fazer isso conversando só com meus botões não ia sair do lugar nunca! Foi na 
conversa que eu fui repensando tudo... Aliás, foi a maior das dificuldades que tivemos, bem... acho que tivemos muitas no começo, por causa do jeito diferente de trabalhar no grupo... Você fazia e contorcia' pra que a gente participasse, e isso era contrastante com a maneira de fazer as reuniões pedagógicas aqui... Então, coordenar as idéias de todo mundo não é fácil, não. Mas é daí que foi surgindo novas questões e novas soluções, o que um fala pensando que aquilo vale pra ele, pode valer pros outros, mesmo que seja para colocar mais lenha na fogueira!!!

De acordo com a professora Bel, reflexão é movimento que se vai 'construindo', 'pensando' e 'repensando' sobre a própria prática, 'conversando' não apenas com os próprios botões, mas em colaboração com os pares a fim de que novos saberes venham 'surgindo', superando modos de agir e de significar o ensino. Ressalta que esse movimento reflexivo não é externo ao indivíduo, nem está fora de seu controle. É determinado por sua ação. É preciso enfrentar desafios, fazer e contorcer, coordenar idéias divergentes, abrir espaços interativos pelos quais a reflexão se desenvolva, é questionar e solucionar, mesmo que isso se reverta em 'colocar mais lenha na fogueira'.

O distanciamento no tempo assegura Bel a se colocar de uma forma que, nas reuniões, foi mais comum à Lia, o fato de explicitar as incoerências que fazem parte da construção permanente da profissionalidade:

a princípio, eu achava um pouco difícil realizar atividades com jogos, porque tinha a falsa idéia de que estava me desviando dos conteúdos que tinham que ser trabalhados. O projeto abriu espaço para mostrar que essa idéia era equivocada, e que os jogos podem ser mais um instrumento para abordar os conteúdos, de forma descontraída, onde o aluno pode aprender brincando e trocando experiências com os outros. (entrevista feedback)

Considerar que o jogo se contraponha aos propósitos escolares faz parte do senso comum. É um dos principais argumentos para que não seja integrado ao ensino. Ao desmistificar essa crença, Bel reconceitua o papel da atividade lúdica, designando-Ihe a função de mediador da aprendizagem e, portanto, instrumental capaz de erigir zonas de desenvolvimento proximal pelas quais os alunos apreendem os conceitos escolares.

Bel avalia que,

para ser sincera, é difícil falar agora do que eu esperava do projeto. Eu sei que estava buscando por alguma coisa diferente, que saísse da lousa, caderno e folhinhas (de exercício). E que a gente tivesse mesmo condição de colocar em prática...

Nesse sentido, o projeto foi ótimo, porque vimos que os jogos podem ser construídos até com sucatas, e a aceitação pelas crianças foi muito boa. Eu não fazia idéia da importância deles mesmos los alunos) fazerem os materiais do jogo, não imaginava que aí já seria 
aprendizagem.

Ao acentuar que os objetos lúdicos, se necessários, podem ser confeccionados pelos alunos, Bel não se limita a reconhecer a facilidade e receptividade na implementação do jogo na rotina escolar. Ela enriquece sua análise destacando uma característica central do preparo desses materiais: o fato de que, ao construí-los, os alunos estão planejando, resolvendo problemas, discutindo e negociando idéias, enfim, estão aprendendo.

Com relação ao processo formativo em geral, as duas professoras apresentam avaliações bastante positivas. Destacamos que, pelo contato constante e afetivo que se estabeleceu entre formadora e professoras, a percepção favorável ao projeto sempre esteve presente, mesmo nos momentos de discordância e insegurança, indicadores da necessidade de se rever o curso da proposta formativa e as estratégias que a estruturavam.

\section{Encaminhando algumas sínteses}

Procuramos demonstrar, no decorrer do processo, como o desenvolvimento profissional das professoras se edificou em alguns aspectos, e noutros é ainda incipiente. De modo geral, Bel se apropriou mais que Lia da abordagem ludo-educativa, mas a apropriação não foi global, refletindo-se mais nas reuniões do que na experiência com os alunos e se constituindo mais em nível aquisitivo do que de aprendizagem especializada.

Surpreendemo-nos, em especial, com a função desempenhada por Lia no desenvolvimento profissional de Bel. Se pressupúnhamos que a segunda professora havia se apropriado melhor da ludo-educação, tornou-se perceptível que, muitas vezes, a experiência profissional de Lia teve grande relevância nas hipóteses, análises e resoluções de problemas encaminhados por Bel. Portanto, as diferenças entre as professoras não se referem exclusivamente ao desenvolvimento profissional, mas às maneiras predominantes com que fazem uso das experiências para seu próprio aprendizado.

Referenciada em experiências concretas anteriores ao projeto, Lia exemplifica e elabora suas observações, assumindo um papel de liderança no grupo. Por vezes, suas interpretações se distanciam da abordagem ludo-educativa, porém é a partir delas que a discussão se aprofunda, pelas trocas de ideais, negociações, divergência de opiniões. Assim, o desenvolvimento de Lia é maior nas reuniões do que na atuação em sala de aula. Ao dialogar com suas colegas e com a formadora, reelabora concepções e se auto-avalia, confrontando-se com modos de pensar cristalizados durante anos de experiência profissional, que não podem ser ignorados ou descartados de imediato. Gradativamente, o discurso de Lia se modifica. Há ocasiões em que novas percepções surgem, lado a lado com as pré-existentes. Noutras, reconhece quão difícil é o processo de mudança da prática, 
especialmente quando envolve valores muito distintos daqueles que se firmaram ao longo de sua carreira. O principal deles é acreditar na capacidade de as crianças encaminharem sua aprendizagem, responsabilizando-se pelas soluções aos desafios definidos pela atividade lúdica, decorrendo em múltiplas conseqüências para a mediação pedagógica, tais como: delegar o preparo do material, intervir na atividade sem fornecer respostas únicas, permitir e incentivar a elaboração de regras de jogo que venham ser a base de autocontrole do comportamento.

Lia tem consciência da importância desses aspectos no processo de ensinoaprendizagem. Deseja e se esforça para estabelecê-los em sua prática. Contudo, é necessário se constituírem num sistema tanto teórico quanto prático. É preciso extrair das observações novas hipóteses e novos conceitos que, generalizados, fundamentem a atuação pedagógica futura. A dificuldade em conceituar ludo-educação se presentifica nas experiências de jogo com os alunos. Preocupada em garantir que a atividade se realize, Lia se adianta, fazendo pelos alunos e controlando sua ação. A mediação pedagógica que, em práticas ludo-educativas, requer constante interação grupo a grupo, só se insinua na última das experiências. Todavia, tal modo de agir contrasta muito com a atuação anterior da professora, quando permanecia boa parte do tempo distante da ação discente.

Consideramos que mesmo as pequenas investidas de Lia têm valor, pois não significam apenas uma aceitação da ludo-educação; simbolizam uma reconstrução dos pressupostos que fundamentam sua profissionalidade.

Em relação ao percurso de Bel, as mudanças foram mais perceptíveis. A professora, com pouca experiência, iniciou o projeto muito receosa e pouco falante, embora sempre atenta a tudo que suas colegas expunham. Nas duas primeiras fases, apenas um aspecto a distingue das demais: quando se pronuncia, invariavelmente questiona.

Primeiro, suas indagações têm um teor fortemente associado à insegurança, à descrença e à inviabilidade de colocar o jogo em prática. Aliás, este gênero de perguntas não é exclusivo dessa professora, pois todo o grupo demonstra as mesmas incertezas, especialmente na segunda fase do projeto, quando dá-se início às experiências em sala de aula.

À medida que a formação se dirige para a experiência de fato, os questionamentos de Bel focalizam o que fazer, como fazer e para que fazer. Que materiais serão utilizados, quais ações docentes precisam ser garantidas e como exercer as mediações são temas constantes das hipóteses que formula. Através de suas indagações, busca se antecipar à experiência, estruturando seu pensamento e imaginando como a ludo-educação pode ser integrada à sua atuação profissional. 
Com respaldo na interação com as colegas e com a formadora, a professora Bel retorna à prática de sala de aula procurando experimentar, colocando à prova as novas idéias em construção: acrescenta um recurso, um procedimento ou uma regra de jogo, possibilitando que os alunos, livremente, criem e orientem sua própria atuação.

Para Bel, o jogo é um mediador de ensino, o que propicia, de uma fase a outra do projeto, atuar em sala de aula de forma mais autônoma. A mediação pedagógica ludoeducativa não ocorre de imediato. Surge em alguns momentos na terceira fase, efetivandose na última experiência lúdica realizada pelo projeto.

Ao analisar a atividade lúdica nos encontros do grupo formativo, Bel investiga a ação discente, compara sua atuação de forma metacognitiva, procurando elaborar sínteses e generalizar princípios. Contudo, os conceitos que formula não são muito distintos dos produzidos pelas outras professoras. A maior parte deles caracteriza-se mais pela apreensão do que pela compreensão, ou seja, são capturados de forma imediata, isolados e fortemente referenciados no contexto de ação.

Bel elabora algumas sistematizações quando o assunto tratado tem relação mais direta com procedimentos específicos, como é o caso da organização do cenário de aprendizagem. Em contrapartida, mesmo concretizando a avaliação da aprendizagem dos alunos em situações lúdicas, as lacunas e contradições demonstram serem necessários avanços de ordem téorico-metodológica para propiciar uma nova perspectiva de avaliação discente, menos controlada pela professora e eficaz para se consolidar a aprendizagem.

A forma como Lia e Bel desenvolvem sua aprendizagem é distinta. Lia enfoca mais a observação e a exemplificação do que Bel. Em contrapartida, esta professora tende mais a indagar e, a partir da reunião de novas informações, elabora soluções para sua ação futura. Portanto, não se trata de contrapor o desenvolvimento profissional entre Bel e Lia. Há, evidentemente, questões que necessitam de maior aprofundamento. É justamente por tais resultados que julgamos serem necessários novos investimentos na formação ludo-educativa a fim de que Bel transforme as aquisições consolidadas durante o projeto em aprendizagens especializadas, até que seja viável elevá-las ao nível integrativo de desenvolvimento. Por sua vez, Lia demonstra potencial para desenvolver o ensino lúdico, necessitando destituir-se de crenças que não colaboram com seu desenvolvimento profissional. Contudo, seu interesse pelos jogos e seu compromisso com a educação são os pilares do potencial para extrair de suas exemplificações e observações, não apenas uma, mas várias hipóteses, a fim de propiciar transformações na concepção de ensino e nos significados que atribui à pratica ludo-educativa. 


\section{6 - CONSI DERAÇÕES FI NAIS}

Neste estudo, objetivamos responder à pergunta: em que medida o projeto de formação de professores, alicerçado pela ludo-educação, contribuiu para o desenvolvimento profissional das professoras? Desenvolvemos a análise através de um estudo de casos, focalizando o percurso formativo de duas das participantes da proposta.

Devido à complexidade inerente ao desenvolvimento profissional e à caracterização do projeto, enfocamos as primeiras mudanças, expressas pelos saberes ludo-educativos emergentes, circunscritos por elaborações inconclusas, ainda não consolidadas no desenvolvimento, mas que fomentam a transformação reflexiva da atuação profissional por meio de ensaios iniciais de articulação entre jogo e ensino.

As estratégias formativas foram estruturadas com a finalidade de favorecer a atuação docente de:

$\leftrightarrow$ planejar, realizar, avaliar e reorganizar reflexivamente práticas ludo-educativas a fim de integrá-las ao ensino;

$\Leftrightarrow$ interagir com os educandos por meio de atividades coletivas e cooperadas, propiciando a aprendizagem auto-regulada e autodirigida discente e contribuindo para seu desenvolvimento psicossocial;

$\stackrel{\leftrightarrow}{\hookrightarrow}$ investigar a própria atuação profissional, num processo metacognitivo que ascendesse à construção de conceitos ludo-educativos significativos para promover 0 desenvolvimento de sua profissionalidade.

Objetivando criar um espaço em que as professoras analisassem sua atuação, os alunos, os objetos de conhecimento, planejando e avaliando experiências lúdicas postas em ação, o projeto foi emoldurado pelo isomorfismo (homologia dos processos) entre a formação de professores e o processo de ensino-aprendizagem discente. Esse isomorfismo foi designado pelo reencontro das educadoras com sua própria ludicidade, tornando-a presente na forma de compreender o desenvolvimento humano e a concebendo como parte integrante da atuação pedagógica. Elas rememoraram a época de infância, jogaram, criaram brinquedos, como também se encantaram com a ludicidade de seus alunos e vivenciaram com eles os desafios de vincular jogo a conceitos escolares, reconhecendo o valor de atuação lúdica no desenvolvimento de potencialidades cognitivas, afetivas e sociais.

A atividade discente, apesar de não fazer parte do escopo de nosso estudo, foi decisiva desde o início do projeto, quando todo o grupo de professoras pouco acreditava nas reais possibilidades de incluir o jogo na rotina educativa. Com a realização das primeiras experiências em sala de aula, devido o envolvimento dos alunos com as atividades e a 
criatividade com que atuavam, tornou-se mais importante questionar como estabelecer as práticas ludo-educativas, analisando e definindo os papéis a serem assumidos pelo jogo, pelos alunos e pela professora no cenário de aprendizagem.

As inseguranças, os medos, as incertezas, as negações, os pedidos de orientação técnica e de acompanhamento pari passu formaram um conjunto cognitivo-afetivo de não-saberes e inseguranças decorrente do empenho das professores em experienciar e compreender o jogo como mediador de aprendizagem, não se tratando, portanto, de transpor métodos de ensino ou substituir outras atividades pedagógicas pelo jogo.

Se, de um lado, julgamos positivas tais atitudes, elas impuseram respostas cabíveis às necessidades formativas que foram se explicitando nos anseios e nas expectativas das professoras. Nesse sentido, o próprio projeto de formação de professoras foi experimental, devido ao seu formato e às condições em que se realizou. A partir dessa experiência formativa, consideramos necessário - à formação que proponha o jogo como mediador do processo de ensino-aprendizagem - contar com uma estrutura em que as experiências ludoeducativas sejam planejadas, realizadas e avaliadas, num contínuo cíclico e ascendente que favoreça a autonomização profissional.

0 fato de enfocarmos o início de um processo de desenvolvimento - as primeiras mudanças ocorridas durante a formação - determinou a criação de um sistema de análise bastante minucioso, uma lente de aumento cujo intuito foi garantir fidedignidade às interpretações.

Mediante a organização de duas coletâneas dos dados videogravados, de reuniões do grupo formativo e de realização da atividade em sala de aula, elaboramos temas e categorias específicos para cada conjunto. Desse modo, a investigação se pautou na correlação entre temas e categorias pertinentes a cada coletânea.

$\mathrm{Na}$ primeira parte da análise, essa estruturação resulta na descrição analítica de todo o projeto, propiciando detectarmos correspondências entre a trajetória formativa e as principais mudanças das professoras, indicativas dos saberes em construção e de processos reflexivos.

A comparação entre as fases do projeto possibilita precisarmos onde e por que as distinções e similaridades se edificaram, aprofundando a compreensão sobre as múltiplas facetas do desenvolvimento profissional das educadores. Propicia, ainda, averiguarmos em que aspectos a insuficiência do tempo de projeto foi mais determinante da instabilidade e dificuldade para integrar práticas ludo-educativas à rotina escolar.

Avaliar o processo de formação em sua totalidade não seria suficiente para a investigação mais profunda sobre a singularidade do desenvolvimento profissional de cada 
professora. Por isso, a segunda parte da análise refere-se ao processo formativo de duas professoras que, extremamente envolvidas com a proposta, fase a fase denotam contrastes na forma como se apropriam do jogo educativo.

Ao examinarmos o projeto segundo os diferentes modos de aprender propostos por Kolb, identificamos - na estrutura da proposta e ao longo de seu desenvolvimento - o enfoque a um ou outro aspecto do ciclo de aprendizagem experiencial (experiência concreta, observação reflexiva, conceituação abstrata e experiência ativa).

As reuniões formativas são tão essenciais quanto as experiências de jogo; ambas unem modalidades de aprendizagem.

Assim, a experiência concreta equivale ao contato direto das docentes com os jogos nas reuniões da primeira fase e, depois, em todas as ocasiões em que experienciam o jogo educativo com seus alunos. De modo geral, nas reuniões, a aprendizagem pela experiência concreta é expressa por juízos de valor, convicções, impressões e sentimentos sobre o vivenciado. A apreciação do que sucedeu em sala de aula, especialmente através de exemplificações, é o reflexo afetivo da experiência, sem interrupções ou filtros.

A observação reflexiva, importante para dimensionar a ação tanto em sala de aula como nas reuniões, predomina nos momentos de planejamento dos jogos. Nessas ocasiões, as professoras respaldam-se em experiências vinculadas ou não ao projeto, procurando descrevê-las e, ao mesmo tempo, selecionando e extraindo elementos válidos ao objetivo de elaborar hipóteses e ordená-las de modo coerente a fim de estruturar previamente as bases para a concretização das atividades ludo-educativas com suas classes.

Em relação à conceituação abstrata, a própria natureza desse processo impede realizá-la durante a ação. Contudo, nas reuniões, apesar de haver circunstâncias em que os conceitos são foco central das análises das professoras ou estão explicitamente implicados em estratégias formativas específicas, a formulação de noções conceituais se presentifica apenas nos encontros de avaliação dos jogos das terceira e quarta fases, insinuando a produção de novos saberes, formulados a partir da atribuição de sentido ao que se experienciou. É importante salientar que, ao tratarem de conceitos, as professoras se detêm a um ou outro aspecto, sem construírem princípios generalizados e complexamente diferenciados que as capacite compreender a experiência sob diferentes ângulos. Por isso, são essencialmente idéias ou noções conceituais, e não propriamente um sistema conceitual integrado e hierarquizado.

No decorrer do projeto, a experimentação ativa - condicionada pela transformação do conhecimento em novas experiências, num processo de exteriorização - apresenta-se no plano mais imediato de resolução de problemas, acentuadamente nos encontros de 
planejamento. Apesar de seu teor pragmático - característico dessa modalidade de aprendizagem - essas soluções refletem suposições que ainda não foram submetidas à testagem.

Relacionando a análise sobre o projeto em geral ao estudo de casos, vislumbramos que a experiência ativa se efetivou, combinada à experiência concreta, na quarta fase da proposta de formação. Desse modo, no jogo de Tapão, a atuação pedagógica de Bel envolve alguns dos conhecimentos específicos de ludo-educação, articulados na elaboração de alternativas próprias, demonstrando maior independência no preparo do jogo e na mediação durante a realização da atividade.

Essas modalidades não são, de nenhum modo, excludentes. No entanto, o predomínio de uma em relação às demais, em cada momento da formação, indica que as diferentes estratégias foram fundamentais para todo o ciclo de aprendizagem experiencial se formar.

Especificamente para o estudo de casos, a triangulação alinhavou videogravações de reuniões e de realização do jogo em sala de aula, diário de campo e entrevistas. Em relação à coletânea das reuniões, definimos os seguintes temas: jogo - recursos e procedimentos; caracterização do jogo educativo; jogo - conceituação e atuação discente. Para a investigação sobre a inserção de jogos em sala de aula, enfocamos: organização do cenário de aprendizagem; mediação pedagógica; interação social; avaliação da aprendizagem e do desenvolvimento.

No detalhamento do discurso e da prática ludo-educativa, realçamos os temas em que as reflexões são mais expressivas, em que somente se insinuam e os casos em que não é possível evidenciar processos reflexivos na e sobre a atuação profissional.

Embora nos detendo na especificidade da proposta de formação, não ignoramos a relevância de dois fatores que, desde o princípio, demarcam distinções no curso profissional das professoras. Um deles diz respeito ao tempo de profissionalização. Enquanto Lia tem dezoito anos de experiência em educação, desempenhando outras funções além do magistério, a professora Bel está no início do exercício profissional - o ano em que o projeto é realizado corresponde ao terceiro em que leciona para classe de Ciclo I, sendo sua primeira experiência com $3^{\mathrm{a}}$ série. I gualmente são distintivas as características do alunado e de currículo entre a $1 \underline{\text { ạ }}$ e a 3 a séries do Ensino Fundamental.

Da análise sobre a realização de jogos em sala de aula, a organização do cenário de aprendizagem é o tema que possui maior qualidade das atividades desenvolvidas por Bel e Lia. Ao final do projeto, é perceptível quanto as professoras aprimoraram sua atuação, demonstrando suficiente autonomia para fornecer aos alunos as principais condições relativas ao preparo dos jogos, bem como assegurando a existência e manutenção da 
interação entre pares.

As principais diferenças entre Bel e Lia referem-se à mediação pedagógica, sobretudo durante a realização do jogo. Nesse aspecto, as observações e intervenções de Bel são mais expressivas para fornecer aos alunos condições de auto-regularem seu comportamento e sua aprendizagem, avaliarem habilidades e conhecimentos constituídos e em constituição, bem como interagirem em colaboração recíproca. Não se trata de postular que as mediações de Lia são destituídas dessas características. Contudo, a presença de controles e, sobretudo, a necessidade de se antecipar à ação discente geram limitações à dinâmica da atividade lúdica e, por conseguinte, é menor o campo de atuação dos alunos nas diversas tarefas que envolvem o jogo.

Quanto à avaliação discente da aprendizagem e à interação propiciadora da coparticipação decisória (professora/alunos), as mudanças não têm a mesma intensidade e qualidade observada nos demais temas. Nos dois casos, a avaliação do jogo com os alunos legitima-se mais como espaço de apreciação e expressão de afetos. Somente na última experiência e, especificamente, no caso da professora Bel, há uma tentativa de ascender à avaliação que promova reelaboração de conhecimentos e novas aprendizagens - inclusive pelo fato de a professora propor aos alunos, e sistematizar com eles, os registros de regras do jogo e das conclusões da classe sobre a experiência.

A interação, destinada a autorizar os alunos a participarem de maneira mais efetiva de seu processo de aprendizagem, é circunscrita pela relação entre pares, sem contar com intervenções pedagógicas que a estimulem e a referendem. Adicionalmente, as decisões de maior envergadura sobre a caracterização do jogo educativo são determinadas exclusivamente pelas professoras.

A autonomia discente está intimamente relacionada à mediação pedagógica e tem grande relevância na etapa de avaliação do jogo. Por esse motivo, pressupomos que a continuidade de experiências ludo-educativas e da reflexão sobre elas poderá favorecer a descentralização do controle docente, ampliando e melhorando a mediação e estabelecendo um clima menos assimétrico do diálogo com os alunos no momento de avaliar a atividade lúdica.

De modo geral, nos encontros formativos a atuação das professoras é mais ampla e elaborada do que na realização dos jogos. 0 comportamento de ambas gradativamente se eleva entre as quatro fases do projeto; especialmente entre a segunda e a terceira, quando passam a tomar decisões estruturais sobre o projeto, suas indagações e observações são postuladas com maior desenvoltura e surgem tanto a proposição de problemas quanto as formas de solucioná-los. 
O debate sobre os diferentes componentes do jogo educativo é tão constante quanto o exame sobre o perfil do corpo discente. Assim, são temas amplamente discutidos 0 planejamento e a avaliação de recursos e procedimentos, a caracterização das regras dos jogos, bem como a aprendizagem e o comportamento dos alunos. Todavia, há expressivas distinções na forma como cada professora os aborda. Bel articula hipóteses, analisa e desenvolve soluções mais compatíveis com os princípios da ludo-educação. Especialmente nas duas últimas fases da trajetória de formação, a professora desenvolve suas reflexões sobre a ludo-educação visando implicá-la à sua profissionalidade.

Lia tende a coordenar conhecimentos sobre o jogo com acepções de outra natureza, acentuadamente dirigidas a práticas transmissivas de ensino. No entanto, em suas reflexões, não se exime de expor essas contradições, evidenciando que, para ela, é indispensável modificar idéias e valores - ainda que esse seja um processo difícil e penoso - e é essencial respeitar o próprio ritmo de transformação de sua atuação profissional.

Embora haja ocasiões em que as interações firmadas no grupo formativo contribuam para as professoras formularem noções abstratas sobre o ensino lúdico, na maior parte do tempo ambas demonstram grande dificuldade para generalizar conceitos que venham a integrar um sistema único, caracterizado pela complexidade de diferenciação e de hierarquização.

Referindo-se a questões de indiscutível relevância para a elaboração de princípios relativos à prática ludo-educativa, a maioria das idéias apresentadas pelas professoras refletem preocupações e necessidades de caráter performático e, portanto, condicionadas sobretudo à experiência concreta e contextual, dificultando ordená-las num nível mais complexo do que o da aquisição de conhecimentos.

Um sistema conceitual íntegro e ordenado hierarquicamente, qualificado também pelo refinamento da diferenciação entre conceitos, demanda um processo demorado, cuja complexidade não poderia ser obtida através dessa experiência formativa, nos termos em que foi concretizada. No entanto, examinar sua constituição inicial ilumina alguns fatores fundamentais para compreender a discrepância entre a genérica valorização do jogo e sua inexistência na escola de Ensino Fundamental, fornecendo novos parâmetros para julgar como se estabelecem os vínculos entre a elaboração de conceitos e a experiência educativa com jogos.

De acordo com os resultados do estudo de casos, hipotetizamos que a dificuldade em produzir reflexiva e autonomamente conceitos, nas reuniões formativas, influencia fortemente na qualidade do exercício de práticas de ensino ludo-educativo.

Ao conceituarem, as professoras tendem a focalizar um ou outro elemento da 
experiência, dirigindo a atenção para necessidades iminentes, ou seja, objetivos imediatos. Também é nossa hipótese que, entre as duas professoras, a sistematização de conceitos através de materiais e estratégias especificamente dirigidas a essa finalidade - seria mais necessária para Lia, a fim de contribuir para que ela própria pudesse contrastar pressupostos ludo-educativos com outros, integrantes do seu saber-fazer pedagógico.

Contudo, ao problematizarem acerca de conhecimentos teóricos que embasam a abordagem ludo-educativa, as professoras aludem à experiência tanto retrospectiva quanto prospectivamente, tornando-a objeto de reflexão, favorecendo a compreensão dos demais aspectos implicados na inserção dos jogos no ensino, cujo teor empírico não os torna menos importantes do que a conceituação.

Ascender a uma compreensão plena sobre ludo-educação demanda tempo, mediações e condições estruturais específicas, sobretudo quando se almeja tornar a ludo-educação um dos elementos constitutivos do processo emancipatório da profissionalidade docente. Desse modo, ao final do projeto, julgávamos que a emergência de conceitos sobre a ludo-educação - precários e atrelados à prática imediata - insinuava que dificilmente a experiência formativa havia fomentado condições suficientes para a continuidade de experiências com jogo, realizadas reflexiva e autonomamente após o término da experiência de formação. Entretanto, decorridos noves meses de nosso último contato com a escola, a professora Bel nos informa ter incluído jogos desde o planejamento do ano letivo - segundo o modelo vivenciado durante a formação - ampliando sua vinculação ao ensino mediante a implementação de séries de atividades lúdicas à rotina de ensino. Essa informação sugere transformações mais duradouras na profissionalidade de Bel do que pressupúnhamos, potencializando um nível mais complexo de desenvolvimento profissional através do 'aprender fazendo'.

As diferenças de resultados entre os temas, tanto das reuniões quanto da realização de jogo em sala de aula, sugerem níveis de complexidade igualmente distintos entre os componentes da ludo-educação, acentuando que a integração e a diferenciação não se constituem de forma equânime.

A metodologia empregada proporcionou obtermos um amplo espectro de informações pertinentes à complexidade do curso de desenvolvimento profissional das professoras. Correlacionando os temas às categorias de análise, precisamos a formação das professoras, tanto do ponto de vista dos conhecimentos aprendidos como dos principais mecanismos utilizados por elas para aprender.

Em primeiro lugar, averiguamos que o acento numa determinada categoria corresponde às principais divergências na abordagem de um tema. Assim, a indagação é, seguramente, a 
forma privilegiada de Bel enunciar suas proposições nas reuniões, enquanto há predomínio da exemplificação na explanação de Lia.

Ao se posicionar, Bel habitualmente recorre ao questionamento como recurso para tratar de um assunto, hipotetizar e encontrar vias de ação a serem experimentadas na prática.

Freqüentemente, as discussões são enriquecidas pelos relatos fornecidos por Lia. Entretanto, as observações que ela produz sobre seus próprios exemplos, ao demarcarem posicionamentos conclusivos, legitimam percepções e valores pré-existentes nem sempre condizentes com os fundamentos da ludo-educação.

Pressupomos que a indagação seria tão necessária para Lia (re)construir saberes e valores da prática profissional, transformando suas reflexões sobre o jogo em novos aprendizados, quanto a exemplificação e a observação ofereceriam a Bel maior segurança em suas próprias análises.

Quanto à experiência de jogo, as mediações de Bel são favorecidas por dois modos de agir: freqüentemente observa a atuação discente e, em certas situações, intervém através de problematizações. Em contrapartida, a atuação de Lia é determinada sobretudo pela explicação e avaliação de caráter corretivo. Em função dessas diferenças, postulamos que a combinação entre as modalidades beneficiaria a integração do jogo ao ensino, nos dois casos. Ao vincular explicações à problematização, as intervenções de Bel poderiam fornecer elementos mais concretos para os alunos auto-regularem sua atuação e aprofundarem seus conhecimentos.

Conclusivamente, notamos que às exemplificações de Lia nas reuniões correspondem 0 grande volume de orientações explicativas a seus alunos. Por sua vez, Bel tende a questionar e problematizar. Concordamos com a perspectiva de Kolb de que seja inoperante designar um modo de aprender 'mais apropriado'; o que existem são maneiras singulares de cada pessoa se apropriar do conhecimento. Assim, a diferença qualitativa da atuação de Bel é determinada sobretudo pelo conteúdo do que pelo modo de atuar. Evidentemente, indagar ou encontrar respostas a problemas são mecanismos imprescindíveis à reflexão. Contudo, pouco contribuiriam se as indagações se encaminhassem para obtenção de respostas únicas e fixas, bem como seriam ineficazes soluções enredadas à atuação restritiva e simplista.

Deslindar os primórdios de desenvolvimento alusivos à apropriação do jogo como mediador de ensino também se relaciona ao exame das estratégias formativas. Consideramos que algumas delas foram especialmente importantes para a emergência de idéias abstratas, a partir das quais a significação do jogo educativo tenha se convertido em novas experiências empreendidas, de forma autônoma, por Bel.

Além da variação de estratégias ter se mostrado bastante benéfica à reflexão de modo 
geral, dois mecanismos foram especialmente relevantes para determinar mudanças no curso do projeto e na forma como as professoras redimensionaram o papel da atividade lúdica no ensino: a realização do jogo de Percurso, com as professoras, no intuito de fomentar a discussão sobre os princípios da ludo-educação (segunda fase) e a elaboração de um instrumento para aprimorar a observação da prática (quarta fase).

Ainda em relação à variabilidade de estratégias, recorrer às videogravações como estratégia para a reflexão sobre a prática transformou-se num mecanismo distinto de seu propósito original, mas igualmente importante. Mais que servir à troca de idéias ou fomentar e reorganizar abstrações, nas ocasiões em que as professoras assistem às imagens gravadas se produz um clima interativo marcado pela exposição de afetos e apreensão apreciativa, contribuindo para se identificar e valorizar a ação discente.

Postulamos que a multiplicidade, inerente à educação, deva balizar a preparação de projetos formativos. Assim, outros elementos, que não fizeram parte dessa experiência de formação, podem enriquecer o trabalho. Indicamos, em especial, a criação de registros escritos pelas professoras - em que a prática lúdica de ensino seja objeto de investigação e a elaboração de portfólios da produção discente, orientando o processo de reflexão da prática docente e se tornando um meio para que os educandos auto-avaliem seu percurso de aprendizagem.

$\mathrm{Na}$ execução do projeto, algumas tentativas de incorporar esses dois procedimentos apontaram que também eles resultam de um processo de transformação da pratica pedagógica. Mesmo que não tenham se instaurado efetivamente, foi possível principiar a construção de significados e conscientização acerca de sua utilidade a fim de se tornarem rotineiros e respaldarem a permanente reflexão do educador.

A multiplicidade também rege as interações do contexto educativo. Na proposta, o nível microssistêmico de relações entre educadores, entre educadores e formadora, entre educadores e educandos propiciou atingir o mesossistêmico, no contexto âmbito escolar. Embora as estratégias formativas tenham se concentrado num pequeno núcleo de ação, algumas vezes os educadores insinuaram a ampliação do espaço de intersecção entre formação e atuação.

Nossas próprias reflexões sobre a proposta formativa nos fazem crer que o jogo educativo possa se tornar uma realidade da escola publica de Ensino Fundamental, sendo reconhecida sua relevância como mediador da aprendizagem escolar. A origem dessas conclusões não se deve unicamente ao nosso enfoque teórico sobre a ludo-educação; decorre do fato de termos compartilhado com as professoras do mesmo desejo para integrála ao cotidiano de sala de aula e, juntas, termos nos empenhado por torná-la exeqüível. 
Por essa razão, as condições de execução do projeto impõem a necessidade de estabelecê-lo sob novas bases. Tendemos a considerar que o vínculo entre escola e universidade seja uma das mais viáveis.

Alguns espaços estão se abrindo e se fortificando no interior de algumas das principais universidades, que têm investido seriamente na formação de professores, tanto de Educação Infantil como de Ensino Fundamental. Consideramos que, dessa forma, acordos institucionais sejam profícuos para dar sustentabilidade a projetos de formação mais duradouros e ampliar as interações entre os espaços de trabalho e pesquisa, legitimando e dando continuidade à investigação do educador sobre sua prática e diminuindo a distância entre escola e universidade e, mais especificamente, entre jogo e educação.

É nesse sentido que também consideramos o envolvimento de centros universitários para que os educadores conheçam as diretrizes que fundamentam a ludo-educação e possam se referenciar nela para ampliar e transformar reflexivamente sua atuação profissional, pela continuidade de pesquisas e ações formativas dirigidas à relação entre jogo e desenvolvimento profissional docente, inclusive com o intuito de estender a perspectiva ludoeducativa ao âmbito da formação inicial. 


\section{7 - REFERÊNCI AS BI BLIOGRÁFICAS}

ALARCÃO, I. Escola reflexiva e desenvolvimento institucional. Que novas funções supervisivas? In: OLIVEIRA-FORMOSINHO, J. A supervisão na formação de professores. Porto: Porto Editora (Colecção Infância), 2002, p.217-238.

Reflexão crítica sobre o pensamento de D. Schön e os programas de formação de professores. Revista da Faculdade de Educação da USP, v.22, n.2, p.11-42, 1996.

ALMEIDA, M. I. de. O Sindicato como instância formadora dos professores: novas contribuições ao desenvolvimento profissional. 1999. Tese (Doutorado em Educação) - Faculdade de Educação da USP, São Paulo.

ALMEIDA, P. Educação lúdica: técnicas e jogos pedagógicos. São Paulo: Edições Loyola, 1998.

ANDRÉ, M. E. D. A. de. Etnografia da prática escolar. Campinas: Papirus, 1995.

ARIÈS, P. História social da criança e da família. Rio de janeiro: LTC, 1981.

AZENHA, M. da G. I magens e letras: Ferreiro e Luria - duas teorias psicogenéticas. São Paulo: Ática, 1996.

BACHELARD, G. O direito de sonhar. São Paulo: Difusão Editorial, 1986.

BAQUERO, R. Vygotsky e a aprendizagem escolar. Porto Alegre: Artes Médicas, 2001.

BARDIN, L. Análise de conteúdo. Lisboa: Edições 70, 1977.

BEARD, C; WILSON, J. P. The power of experiential learning. Londres: Kogan Page, 2002.

BLACK, P; AMMON, P. A developmental-constructivist approach to teacher education. J ournal of teacher education, [S.I], v. 43, n. 5, p.323-335, 1992.

BRASIL. SECRETARIA DE EDUCAÇÃO fUndAMENTAL. Parâmetros Curriculares

Nacionais - Introdução aos parâmetros curriculares nacionais. Brasília: MEC/SEF, 1998.

BROUGÈRE, G. La signification d'un environnement ludique - l'école maternelle à travers son matériel ludique. Les Actes du Premier Congrès d'Actualité de la Recherche en Éducation et Formation. Paris: AECSE, v.2, p.314-319, 1993. J ogo e educação. Porto Alegre: Artes Médicas, 1998.

BURDEN, P. P. Teacher development. In: HOUSTON, W. R. (ed.). Handbook of research on teacher education. New York: Macmillan, 1990, p.311-328.

CARDOSO, B. Ensinar a ler e escrever: análise de uma competência pedagógica. 1997. 
Tese (Doutoramento em Educação) - Faculdade de Educação da USP, São Paulo.

CARNEIRO, M. A. B. Jogando, descobrindo, aprendendo... (depoimentos de professores e alunos do terceiro grau). 1990. Tese (Doutoramento em Comunicação e Arte) - Faculdade de Comunicação e Arte da USP, São Paulo.

CARTER, K. Teacher's knowledge and learning to teach. In: HOUSTON, W. R. (ed.). Handbook of research on teacher education. New York: Macmillan, 1990, p.291-310.

CHANTRAINE-DEMAILLY, L. Modelos de formação contínua e estratégias de mudança. In: NÓVOA, A. (org.). Os professores e a sua formação. Lisboa: Publicações Dom Quixote, 1992, p.139-158.

DEMO, P. A nova LDB: ranços e avanços. Campinas: Papirus, 1997.

DIAS, M. C. M. Metáfora e pensamento: considerações sobre a importância do jogo na aquisição do conhecimento e implicações para a educação pré-escolar. In: KISHIMOTO, T. M. (org.). Jogo, brinquedo, brincadeira e a educação. São Paulo: Cortez, 1997, p.45-56.

ELKONIN, D. B. Psicologia do jogo. São Paulo: Martins Fontes, 1998.

ELLIOTT, J. Recolocando a pesquisa-ação em seu lugar original e próprio. In: GERALDI, C. M. G.; FIORENTINI, D.; PEREIRA, E. M. de A. (orgs.). Cartografias do trabalho docente. Campinas: Mercado das Letras, 2000, p.137-152.

FERRÉS, J. Vídeo e educação. Porto Alegre: Artes Médicas, 1985.

FORMOSINHO, J. A renovação pedagógica numa administração burocrática centralizada.

O Ensino - Revista Galaico-Portuguesa de Sócio-Pedagogia e SócioLingüistica. Braga, n. 7-10, p.101-107, 1984.

FORMOSINHO, J.; MACHADO, J. Autonomia, projecto e liderança. In: FORMOSINHO, J.; FERREIRA, F. I.; MACHADO, J. Políticas educativas e autonomia das escolas. Porto: Edições Asa, 2000, p.117-138.

FRANÇA, G. W. Tia, me deixa brincar: o espaço do jogo na educação pré-escolar. 1990. Dissertação (Mestrado em Educação) - Faculdade de Educação da USP, São Paulo.

FREIRE, P. Pedagogia do Oprimido. Rio de Janeiro: Paz e Terra, 1975.

GARCÍA, C. M. A formação de professores: novas perspectivas baseadas na investigação sobre o pensamento do professor. In: NÓVOA, A. (org.). Os professores e a sua formação. Lisboa: Publicações Dom Quixote, 1992, p.51-76.

GARKOV, A. F. Jogos tradicionais na cidade de São Paulo: recuperação e análise de sua função educacional. 1990. Dissertação (Mestrado em Educação) - Faculdade de 
Educação da UNICAMP, Campinas.

GARRIDO, E. Analisando a interação verbal professor-alunos segundo categorias baseadas no Modelo de Mudança Conceitual. In: BRZEZINSKI, I. Formação de Professores: Desafios. Goiânia: UCG, 1997, p.179-212.

GÉGLIO, P. C. Programas e práticas de formação docente analise de dissertações e teses defendidas em instituições brasileiras no período de 1986 a 1997. 1999. Tese (Doutoramento em Educação) - Pontifícia Universidade Católica, São Paulo.

GERALDI, C. M. G.; MESSIAS, M. G. M.; GUERRA, M. D. S. Refletindo com Zeichner: um encontro orientado por preocupações políticas, teóricas e epistemológicas. In: GERALDI, C. M. G.; FIORENTINI, D.; PEREIRA, E. M. de A. (orgs.). Cartografias do trabalho docente. Campinas: Mercado das Letras, 2000, p.237-274.

GÓES, M. C. R. A abordagem microgenética na matriz histórico-cultural: uma perspectiva para o estudo da constituição da subjetividade. Cadernos CEDES. Campinas: CEDES, v.20, n.50, p.9-25, 2000.

HEDEGAARD, M. A zona de desenvolvimento proximal como base para a instrução. In: MOLL, L. C. Vygotsky e a educação. Porto Alegre: Artes Médicas, 1996, p.341362.

JAPIASSU, R. O. V. Ensino do teatro nas séries iniciais da educação básica: a formação de conceitos sociais no jogo teatral. 1999. Dissertação (Mestrado em Comunicação e Arte) - Faculdade de Comunicação e Arte da USP, São Paulo.

JARVIS, P. Adult and Continuing Education. Theory and practice. Londres: Routledge, 1995.

KINCHELOE, J. A formação do professor como compromisso político - mapeando o pós-moderno. Porto Alegre: Artes Médicas, 1997.

KISHIMOTO, T. M. O J ogo e a educação infantil. São Paulo: Pioneira, 1994.

KOLB, D. Experiential learning. New Jersey: Prentice Haal, Englewood Cliffs, 1984.

LEONTIEV, A. N. Os princípios psicológicos da brincadeira pré-escolar. In: VYGOTSKY, L. S.; LURIA, A. R.; LEONTIEV, A. N. Linguagem, desenvolvimento e aprendizagem. São Paulo: Ícone, 1988, p.119-142.

LÜDKE, M.; ANDRÉ, M. E. D. A. Pesquisa em educação: abordagens qualitativas. São Paulo: EPU, 1986.

MAYRINK, M. F. Refletindo, interagindo, praticando... nas trilhas da construção do conhecimento sobre o ser professor. 2000. Dissertação (Mestrado em Lingüística Aplicada e Estudos da Linguagem) - Pontifícia Universidade Católica, São Paulo. 
MEIRELES, C. O que se diz e o que se entende. Rio de J aneiro: Nova Fronteira, 1980. MERSETH, K. K. Cases and case methods in teacher education. In: SIKULA, J. (ed.). Handbook of research on teacher education. New York: Macmillan, 1996, p.722-744.

MOURA, M. O. A séria busca no jogo: do lúdico na matemática. São Paulo: Cortez, 1996.

NÓVOA, A. Formação de professores e profissão docente. In: (org.). Os professores e a sua formação. Lisboa: Publicações Dom Quixote, 1992, p.15-33.

NUNES, C. do S. C. Os sentidos da formação contínua: o mundo do trabalho e a formação de professores no Brasil. 2000. Tese (Doutoramento em Educação). Faculdade de Educação da UNICAMP, Campinas.

OLIVEIRA, M. K. de. Três questões sobre desenvolvimento conceitual. In: OLIVEIRA, M. B.; OLIVEIRA, M. K de (orgs.). Investigações cognitivas: conceitos, linguagem e cultura. Porto Alegre: Artes Médicas. 1999, p.55-64. - Organização conceitual e escolarização. In: OLIVEIRA, M. B.; OLIVEIRA, M. K de (orgs.). Investigações cognitivas: conceitos, linguagem e cultura. Porto Alegre: Artes Médicas. 1999, p. 81-99. . Linguagem e cognição: questões sobre a natureza da construção do conhecimento. Temas em Psicologia. São Paulo, n. 2, p.1-9, 1995.

OLIVEIRA-FORMOSINHO, J. O desenvolvimento profissional das educadoras de infância: entre os saberes e os afetos, entre a sala e o mundo. In: MACHADO, M. L. de A. (org). Encontros e desencontros em educação infantil. São Paulo: Cortez, 2002, p.133-167.

Fundamentos psicológicos para um modelo desenvolvimentista de formação de professores. Braga, v.3, p.247-257, 1987.

OLIVEIRA-FORMOSINHO， J.; FORMOSINHO, J. (org.). Associação criança: um contexto de formação em contexto. Braga: Livraria Minho, 2001.

ONRUBIA, J. Ensinar: criar zonas de desenvolvimento proximal e nelas intervir. In: COLL, C. et al. O construtivismo na sala de aula. São Paulo: Ática, 1999, p.123151.

OSTROWER, F. Criatividade e processos de criação. Petrópolis: Vozes, 2001.

OTERO, C. O espaço pedagógico do jogo: algumas possibilidades. 1996. Dissertação (Mestrado em Educação) - Faculdade de Educação da USP, São Paulo.

PADILHA, A. R. Atividades lúdicas: sua importância na alfabetização. Curitiba: Juruná. 1999. 
PASCAL, C. e BERTRAM, T. Desenvolvendo a qualidade em parcerias: nove estudos de caso. Porto: Editora Porto, 2000.

PEREIRA, M. I. G. G. Emoções e conflitos: análise da dlnâmica das Interações numa classe de educação Infantil. 1998. Tese (Doutoramento em Educação) - Faculdade de Educação da USP, São Paulo.

PÉREZ GÓMEZ, A. A função e formação do professor/a no ensino para a compreensão: diferentes perspectivas. In: SACRISTÁN, J G; PÉREZ GÓMEZ, A. Compreender e transformar o ensino. Porto alegre: Artmed, 1998, p 353-377.

. O pensamento prático do professor - a formação do professor como profissional reflexivo. In: NÓVOA, A. (org.). Os professores e a sua formação. Lisboa: Publicações Dom Quixote, 1992, p.93-114.

PIMENTA, S. G. Qualificação do ensino público e formação de professores. Relatório Parcial de Pesquisa - Faculdade de Educação da USP, FAPESP. 2000.

A didática na Licenciatura: um estudo dos efeitos de um programa de curso na atividade docente de alunos egressos da Licenciatura. Relatório Final de Pesquisa - Faculdade de Educação da USP, CNPq. 1999.

PIMENTA, S. G. et al. A pesquisa colaborativa na escola como abordagem facilitadora para o desenvolvimento profissional de professores. Relatório Parcial de Pesquisa - Faculdade de Educação da USP, FAPESP. 2001.

PIMENTEL, A. Intersubjetividade e Aprendizagem. In: MARTINS, J. M. (org.) Na Perspectiva de Vygotsky. São Paulo: Quebra Nozes/ Londrina: CEFIL, 1999 p.1325.

Investigando a representação de educadores sobre o jogo na aprendizagem escolar. Relatório Final de Pesquisa, Departamento de Psicologia Social e Institucional da Universidade Estadual de Londrina, 2000.

Um estudo de caso na relação entre psicologia e educação: 0 Programa Alfa. 1997. Dissertação (Mestrado em Psicologia da Educação) - Pontifícia Universidade Católica, São Paulo.

PINHEIRO, L. O brincar na rotina escolar de deficientes mentais: visão de professores. 1992. Dissertação (Mestrado em Psicologia da Educação) - Pontifícia Universidade Católica, São Paulo.

PUGLISI, J. C. O jogo didático no processo ensino-aprendizagem. 1997. Dissertação (Mestrado em Psicologia da Educação) - Pontifícia Universidade Católica, São Paulo.

RABELO, V. Jogos Infantis na escola moderna: jogos de salão. Belo Horizonte: 
Itatiaia, 1998.

RABIOGLIO, M. B. Jogar, um jeito de aprender - análise do pega-varetas e da relação jogo-escola. 1995. Dissertação (Mestrado em Educação) - Faculdade de Educação da USP, São Paulo.

ROCHA, M. S. P. M. L da. O real e o imaginário no faz-de-conta: questões sobre o brincar no contexto da pré-escola. In: GOÉS, M. C. R. de et al. A significação nos espaços educacionais. Campinas: Papirus, 1997, p.63-86.

SAVIANI, D. A resistência ativa contra a nova lei de diretrizes e bases da educação. Princípios. São Paulo: Anita, n. 47, p.66-72, 1998.

SCARPA, R. Era assim, agora não... uma proposta de formação de professores leigos. São Paulo: Casa do Psicólogo, 1998.

SCHÖN, D. Formar professores como profissionais reflexivos. In: NÓVOA, A. (org.). Os professores e a sua formação. Lisboa: Publicações Dom Quixote, 1992, p.77-91. SHAKESPEARE, W. Macbeth. Rio de Janeiro: Paz e Terra, 1996.

SILVA, M. O. E. da. A análise de necessidades de formação na formação contínua de professores: um caminho para a integração escolar. 2000. Tese (Doutoramento em Educação) - Faculdade de Educação da USP, São Paulo.

SPRINTHALL, N. A.; REIMAN, A. J.; THIES-SPRINTHALL, L. Teacher professional development. In: SIKULA, J. (ed.). Handbook of research on teacher education. New York: Macmillan, 1996, p.666-703.

SPRINTHALL, N. A.; THIES-SPRINTHALL, L. The contexts of staff development. In: The teacher as an adult learner: a cognitive-developmental view.

Chicago: University of Chicago Press, 1983, p.13-35.

STAKE, R. I nvestigación con estudio de casos. Madri: Morata, 1998.

THIOLLENT, M. Metodologia da pesquisa-ação. São Paulo: Cortez, 1994.

UEMURA, E. O brinquedo e a prática pedagógica. 1988. Dissertação (Mestrado em Educação). Pontifícia Universidade Católica, São Paulo.

VEIGA, C. X. A. M. I magens sociais e culturais em brincadeiras de construção na educação infantil. 2000. Dissertação (Mestrado em Educação) - Faculdade de Educação da USP, São Paulo.

VYGOTSKY, L. S. Psicologia Pedagógica. São Paulo: Martins Fontes, 2001. La imaginación y el arte en la infancia. Madrid: Akal, 1996. . A formação social da mente. São Paulo: Martins Fontes, 1994. Obras Escogidas. Madrid: Visor. Tomo II [Conferencias sobre psicologia], 1991. 
Thinking and speech. In: RIEBER, R. W. E CARTON, A. S. (eds.). The

collected works of L. S. Vygotsky, New York: Plenum Press, 1987, p.37-285.

VYGOTSKY, L. S.; LURIA, A. R. A criança e seu comportamento. In: Estudos

sobre a história do comportamento: o macaco, o primitivo e a criança. Porto Alegre: Artes Médicas, 1996, p.151-238.

WAJSKOP, G. Concepções de brincar entre profissionais de educação infantil: implicações para a prática institucional. 1996. Tese (Doutoramento em Educação) Faculdade de Educação da USP, São Paulo.

WASSERMANN, S. Brincadeiras sérias na escola primária. Lisboa: Horizontes Pedagógicos, 1990.

WEISZ, T. Por trás das letras. São Paulo: FDE, 1994.

WERTSCH, J. V. Vygotsky y la formación social de la mente. Barcelona: Paidós, 1988.

WERTSCH, J. V.; DEL RIO, P.; ALVAREZ, A. Sociocultural studies of mind. Cambridge: Cambridge University Press, 1995.

WITTGEINSTEI N, L. Investigações filosóficas. São Paulo : Abril Cultural, 1975.

ZEICHNER, K. Para além da divisão entre professor-pesquisador e pesquisador acadêmico. In: GERALDI, C. M. G.; FIORENTINI, D.; PEREIRA, E. M. de A. (orgs.). Cartografias do trabalho docente. Campinas: Mercado das Letras, 2000, p.207236. . Novos caminhos para o practicum: uma perspectiva para os anos 90. In: NÓVOA, A. (org.). Os professores e a sua formação. Lisboa: Publicações Dom Quixote, 1992, p.115-138.

ZIBETTI, M. L. T. Analisando a pratica pedagógica: uma experiência de formação de professores na educação infantil. 1999. Dissertação (Mestrado em Psicologia) Instituto de Psicologia da USP, São Paulo. 
ANEXOS 


\section{ANEXO I - JOGO DO PERCURSO}

O primeiro encontro formativo da segunda fase do projeto foi desenvolvido com o uso de um Jogo de Percurso (Ludus Romanus). Seguindo os mesmos parâmetros, regras e recursos materiais comuns a esse jogo, confeccionamos um tabuleiro com obstáculos, um dado, os peões (em número equivalente ao número de jogadores). As cartelas de questões foram formuladas durante a reunião, a partir de seleção de trechos de textos relativos às atividades lúdicas em geral e à sua relação com a educação.

No jogo, os obstáculos do tabuleiro corresponderam à retirada de uma das trinta cartelas. Assim, ao ter seu peão numa casela com obstáculo (pelo número retirado no dado), a jogadora deveria ler e responder ao conteúdo de uma cartela. De acordo com uma das regras, a adequação ou não da resposta determinava avanços ou recuos do peão nas casas do tabuleiro. Inserimos a regra complementar de que a validade da resposta fosse avaliada pelos jogadores adversários, visando que o grupo utilizasse as questões e respostas como principal objeto de discussão sobre os temas abordados.

A formulação das questões envolveu cinco temáticas (seis cartelas para cada uma), conforme os exemplos a seguir:

1) História do Jogo - exemplos de jogos associados à história da humanidade

Ex: "O aro, precursor do bambolê, é um jogo milenar que exige delicadeza e equilíbrio dos movimentos. Explique como se brinca com ele e garanta seu lugar na casela. Se não souber, deixará de ter direito à próxima rodada!"

2) Conceito de Jogo - características, tipos, exemplos

Ex: “Imagine um 'Palavras-Cruzadas' em que a vertical central forma uma espinha dorsal, onde se lê a palavra 'ludicidade'. Monte entre 4 a 7 palavras que se encontrem na horizontal correlacionadas ao tema. Com 4 ou 5 palavras, avance 2 casas; com 6 ou 7, jogue o dado mais uma vez".

3) Relação entre Jogo e Aprendizagem - conceituação

Ex: “Explique a frase: 'Através do jogo, a criança é capaz de ir além de suas habilidades e capacidades habituais'. Uma explicação convincente por meio de exemplos the rende uma casa à frente. Já uma explicação em que argumente por meio de conceitos e relações com teorias, dá o direito de andar três casas!"

4) Experiência com Atividades Lúdicas - conhecimento empírico

Ex: "Sem olhar para o Tangran ${ }^{76}$, responda rápido: quantas peças o compõem? Se não

${ }^{76}$ Conjunto de sete peças, cortadas a partir de um quadrado. É semelhante a um quebra-cabeças, possui as seguintes figuras geométricas: dois triângulos isósceles grandes; um triângulo isósceles médio; dois triângulos 
souber a resposta, volte 3 casas. E mais, veja se resolve esse enigma: quantas peças de um tangran são usadas para formar um retângulo que tenha $4 \mathrm{~cm}$, supondo que a área do quadrado (uma das peças) é de $1 \mathrm{~cm}$ ? Com a resposta certa, avance 4 casas."

5) Experiência Profissional - solução de problemas para inserção de jogos no ensino

Ex: "O que você diria a uma professora que considera inviável usar atividades lúdicas no ensino porque causa tumulto? Uma resposta convincente, com exemplificação de procedimentos, permite avançar 2 casas. Se o grupo contestar, recue duas."

isósceles pequenos; um quadrado e um paralelogramo. A proporção geométrica entre as peças é a seguinte: 0 triângulo de menor tamanho é a metade do paralelogramo ou do quadrado ou do triângulo médio, além de ser equivalente a $1 / 4$ do maior triângulo. Por sua vez, o maior triângulo corresponde ao dobro da área do triângulo médio. Da combinação entre peças surgem diversas equivalências. Por exemplo, o quadrado e um triângulo pequeno têm, juntos, mesma área que a soma do paralelogramo e de um dos triângulos pequenos. 


\section{ANEXO 2 - ROTEI ROS DAS ENTREVISTAS}

\section{Entrevista I nicial}

Durante uma semana, utilizando o horário de JEI, foram realizados encontros com cada uma das professoras participantes, gravadas em fita microcassete.

0 roteiro de entrevista inicial foi orientado pelas seguintes questões:

1. Quais são suas expectativas em relação ao projeto para sua prática atual?

2. Que aspectos considera essenciais para a formatação do projeto?

3. Quais relações estabelece entre a realização deste projeto e perspectivas para sua atuação profissional?

4. O que entende por jogo educativo?

5. Quais suas experiências pessoal e profissional com jogos e, em particular, jogos educativos?

\section{Entrevistas Final e de Feedback}

Seguimos os mesmos procedimentos da entrevista inicial. A final foi realizada durante a primeira semana de outubro de 2002, com cada professora individualmente. A de retorno (ou feedback) ocorreu nove meses após o termino de nosso contato semanal com a escola, durante o mês de julho de 2003, logo após termos organizado o material para que as professoras selecionadas para o Estudo de Casos pudessem apreciá-lo, modificando e ampliando as informações nele contidas.

No roteiro de entrevista final, as indagações orientadoras foram:

1. De modo geral, em que medida o projeto atendeu a suas expectativas?

2. Que expectativas o projeto abarcou em relação à sua prática docente atual? Exemplifique.

3. O projeto contribuiu para sua atuação profissional? De que maneira?

4. Como imagina que a ludo-educação pode fazer parte da sua rotina educativa?

5. Que aspectos metodológicos do projeto foram mais significativos? Quais os que implicariam mudanças? Indicar as mudanças plausíveis.

A entrevista de feedback se baseou no material previamente organizado sobre o projeto formativo: transcrições de videogravações e entrevistas anteriores. Optamos, portanto, por manter sua característica de instrumento aberto, a fim de possibilitar que o encaminhamento 
fosse assumido pelas professoras, o que determinou enfoque a temas distintos entre as entrevistas.

$\mathrm{Na}$ entrevista de feedback com a professora Bel, foram abordadas sua relação com o ambiente escolar, suas expectativas profissionais e sua apreciação do projeto, sobretudo no que diz respeito a mudanças que passaram a fazer parte de sua prática desde então, bem como temáticas subjacentes a estas mudanças.

$\mathrm{Na}$ entrevista com a professora Lia, procuramos tratar de lacunas acerca de sua compreensão quanto ao papel do jogo na educação, obtendo informações importantes sobre as dificuldades que sentiu na realização das atividades lúdicas com seus alunos, em contraste com sua intensa participação nas reuniões do grupo. Também foram levantados fatores institucionais que, segundo a professora, justificavam as dificuldades percebidas comparando experiências anteriores na sua profissionalidade, em que o jogo havia sido parte integrante do trabalho pedagógico. 


\section{ANEXO 3 - GRÁFI COS DE ANÁLISE DO ESTUDO DE CASOS}

A partir da transcrição da coletânea de encontros formativos e do sublinho de todos temas e categorias, averiguamos como as categorias se distribuem pelos oito temas, através de gráficos representativos dos dados das professoras Lia e Bel. O mesmo procedimento foi utilizado para os encontros do grupo e para o material relativo à realização de atividades lúdicas com os alunos. A análise qualitativa, apresentada no quinto capítulo, foi balizada pelos resultados obtidos nesses gráficos. Através deles, obtivemos as primeiras informações sobre o desenvolvimento profissional das professoras, considerando os diferentes modos de abordarem cada um dos temas.

Ressaltamos, entretanto, que os gráficos focalizam a totalidade da distribuição das categorias pelos temas, desconsiderando os percentis relativos a cada fase do projeto, e que, por não revelarem os significados das discussões e ações das professoras, não podem qualificá-las em relação ao seu processo de desenvolvimento profissional. Exemplarmente, no terceiro gráfico (Fig. 3), em que é indicado o modo como as professoras abordam conceitos de ludo-educação, há grande concentração de análise tanto para Lia como para Bel. Todavia, as análises não produzem 'soluções' na mesma proporção, ou seja, é reduzida a resolução de problemas sobre conceitos, determinada pelas situações em que, além de identificá-los, as professoras os abordam de forma coerente e sistematizada, a fim de propiciarem ampliação e aprofundamento da compreensão sobre os princípios gerais envolvidos nas práticas ludo-educativas. Os gráficos relativos às reuniões seguem abaixo:

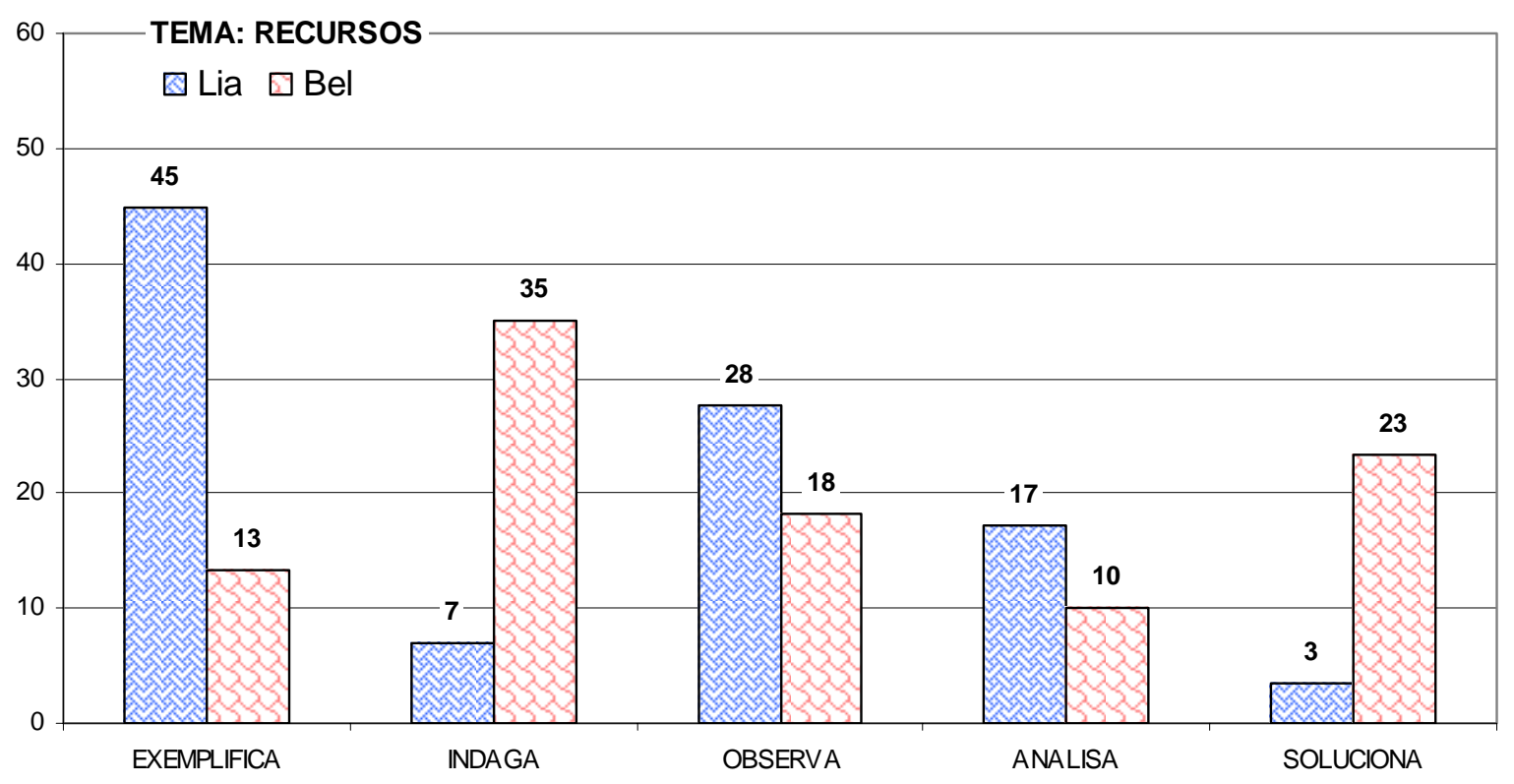

Figura 1 - Tema: "Jogo: recursos e procedimentos" 


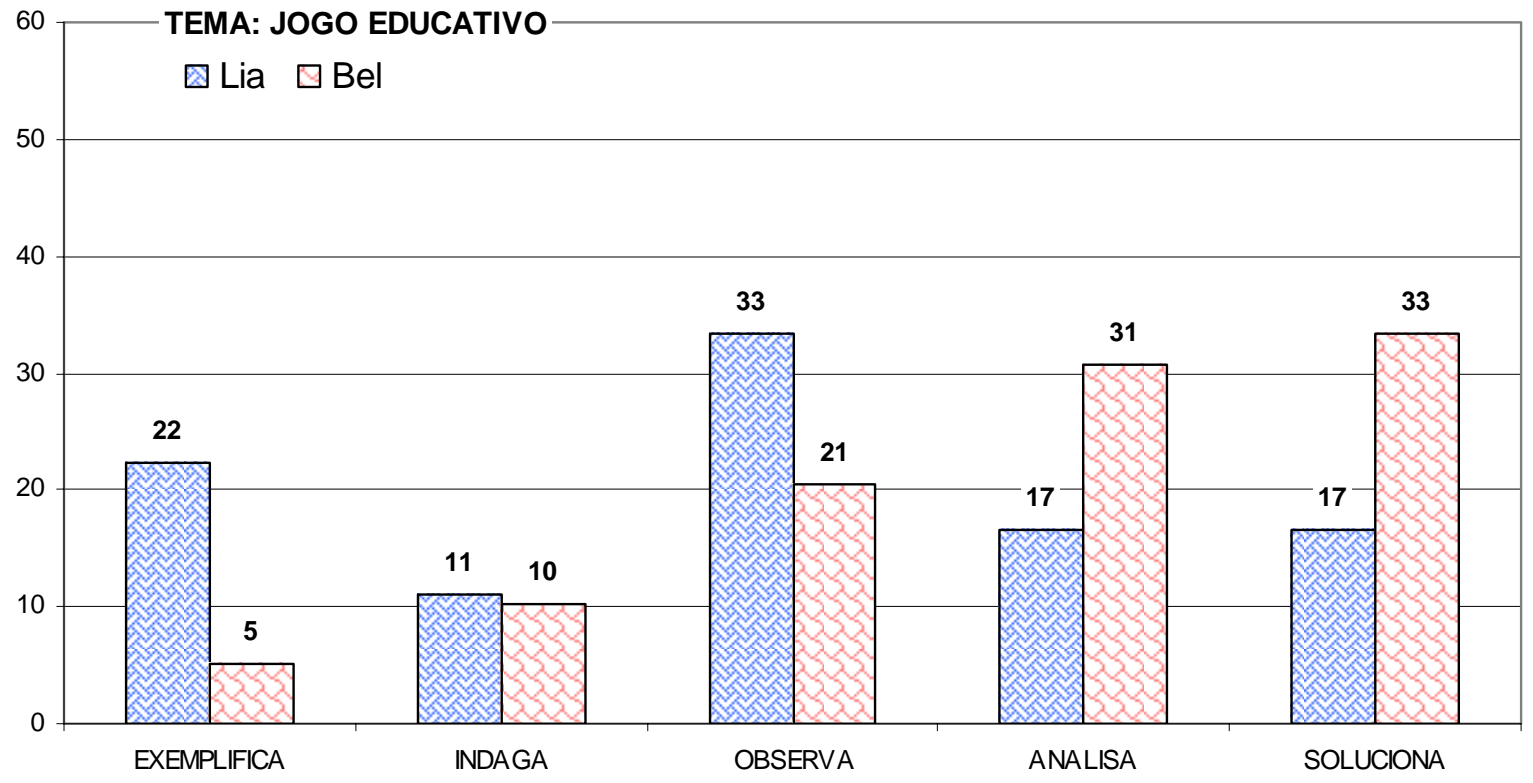

Figura 2 - Tema: Caracterização do J ogo Educativo

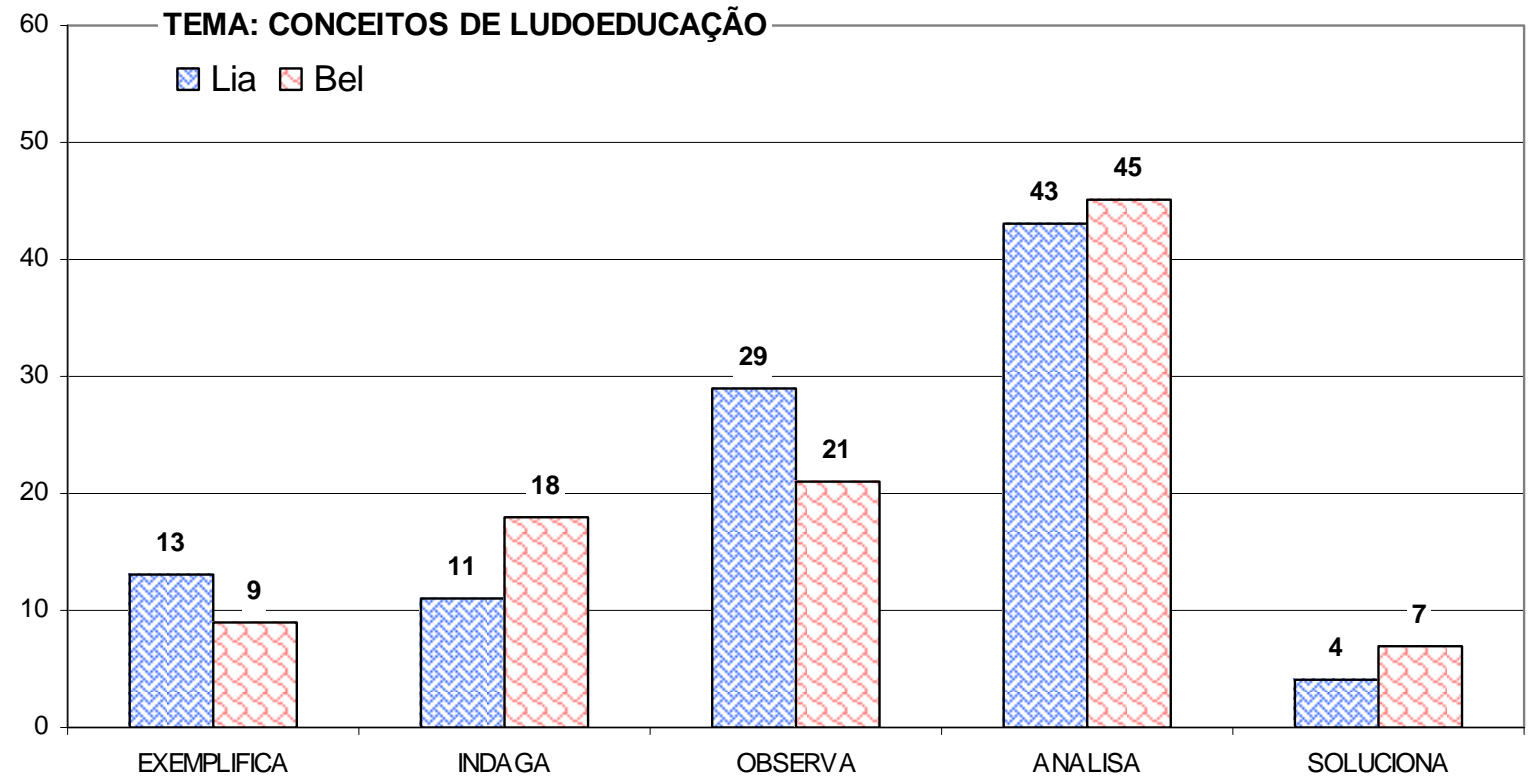

Figura 3 - Tema “J ogo - conceituação" 


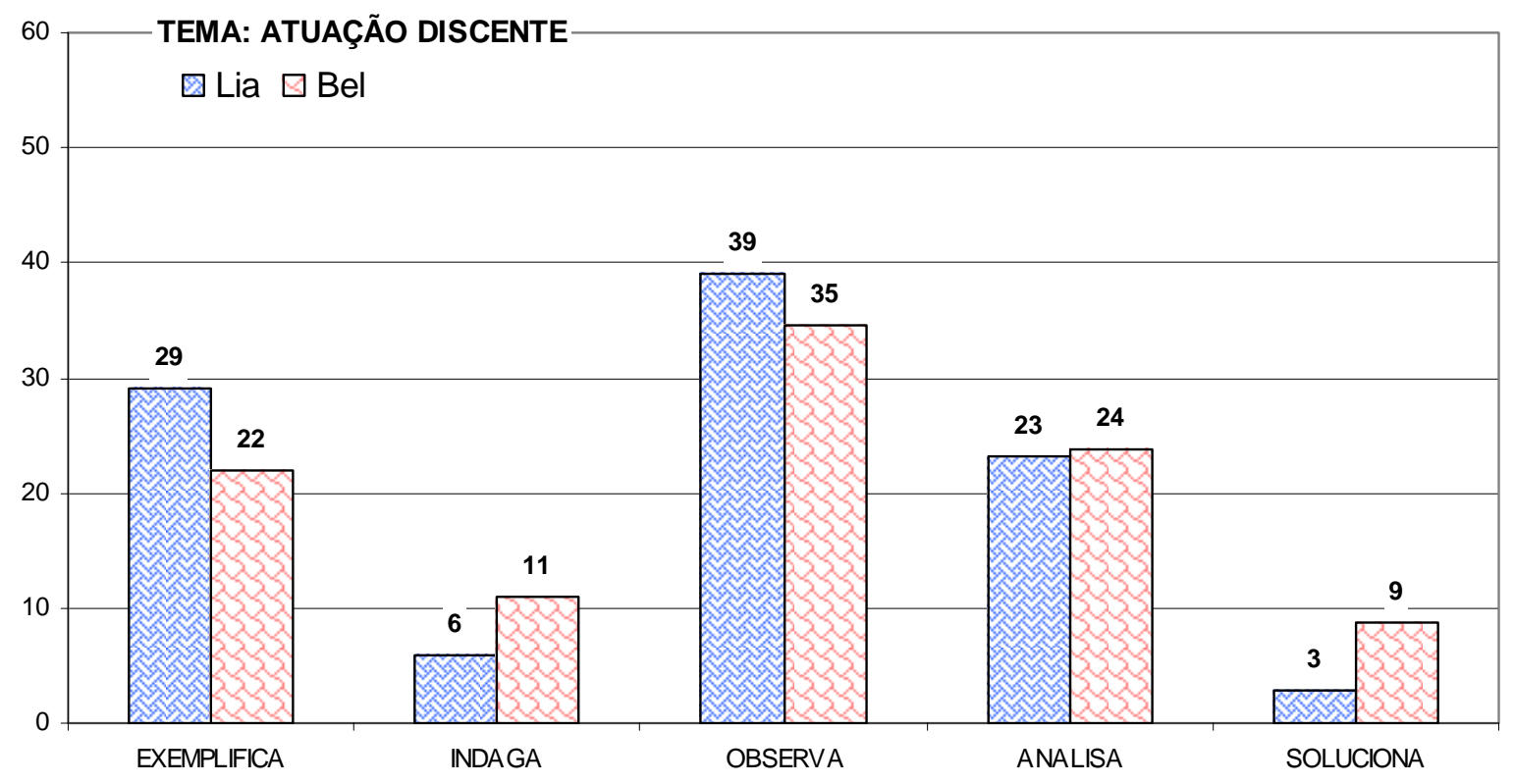

Figura 4 - Tema: "Atuação discente: aprendizagem e comportamento"

Os quatro gráficos seguintes referem-se aos temas de análise da coletânea de realização de jogo em sala de aula.

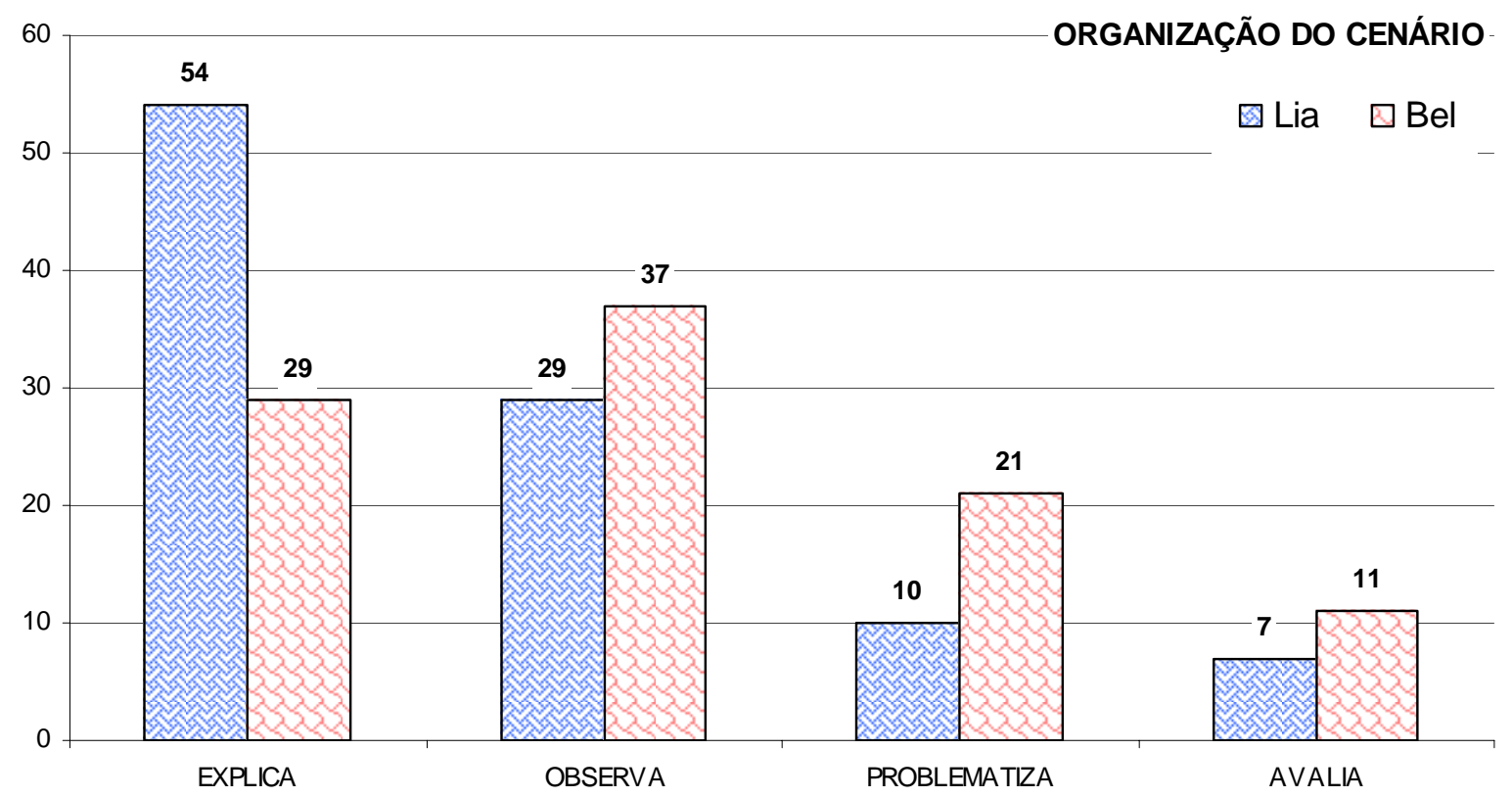

Figura 5 - Tema “Organização do cenário de aprendizagem” 


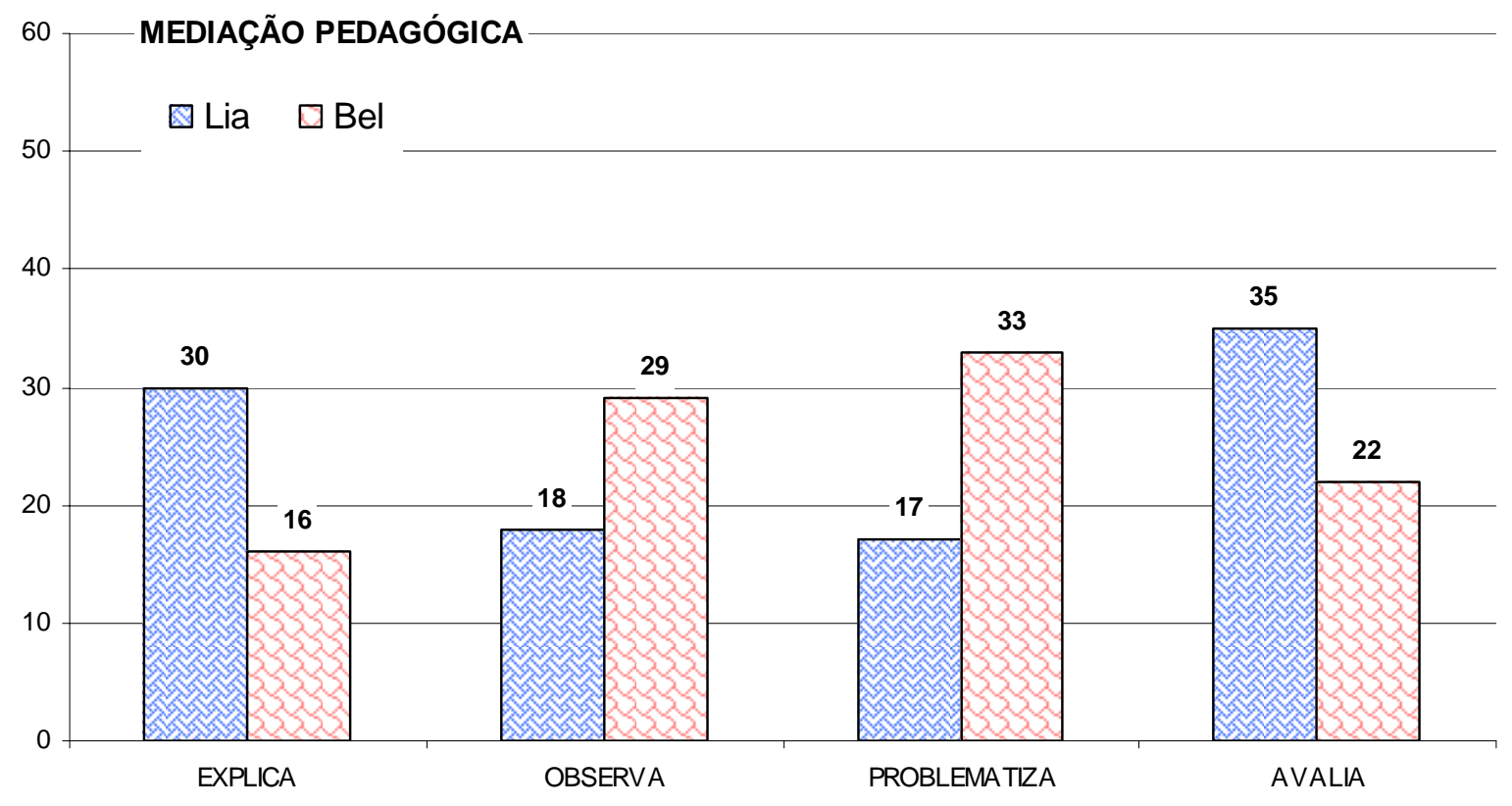

Figura 6 - Tema: “Mediação pedagógica”

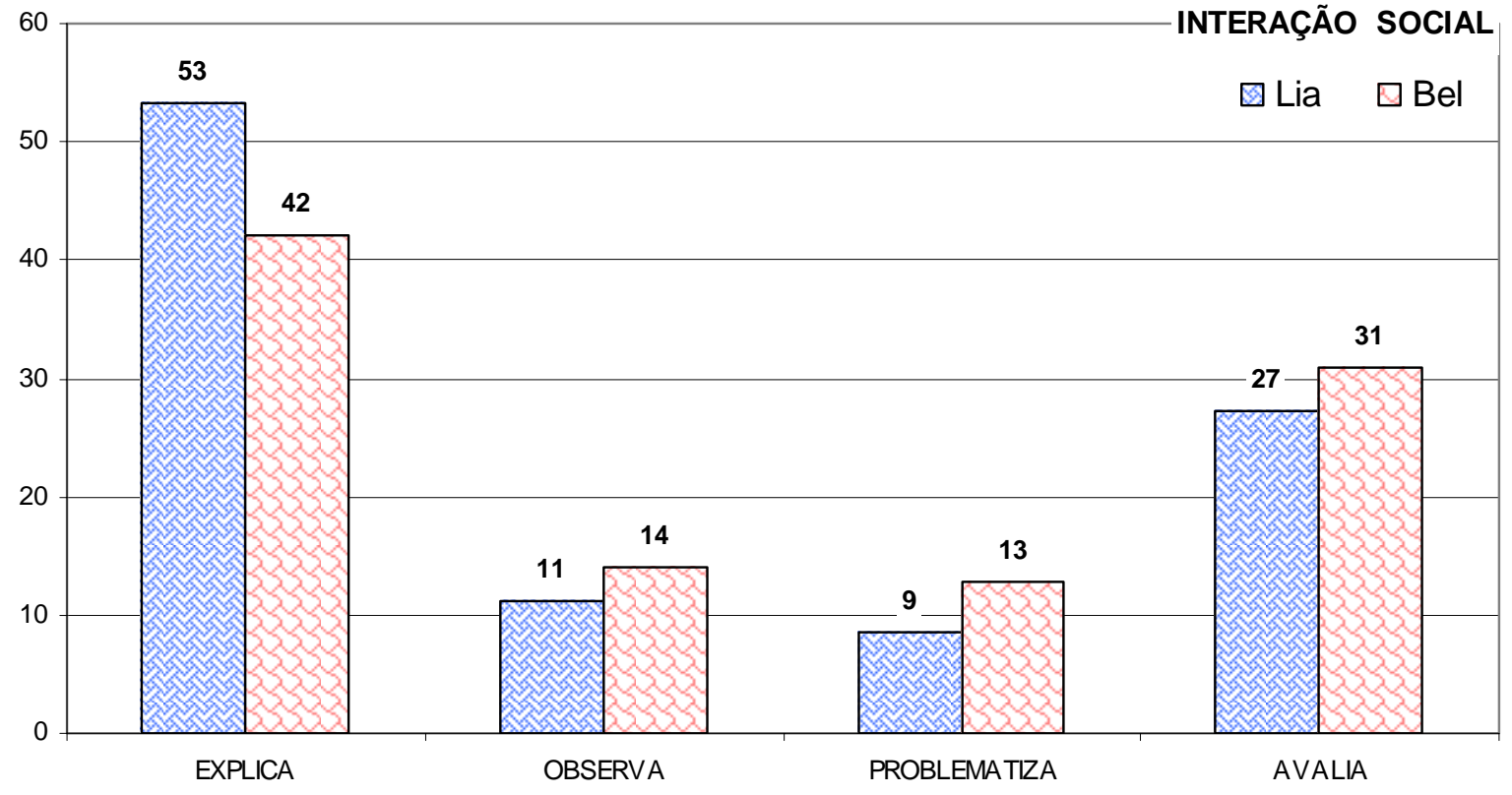

Figura 7 - Tema: "I nteração social” 


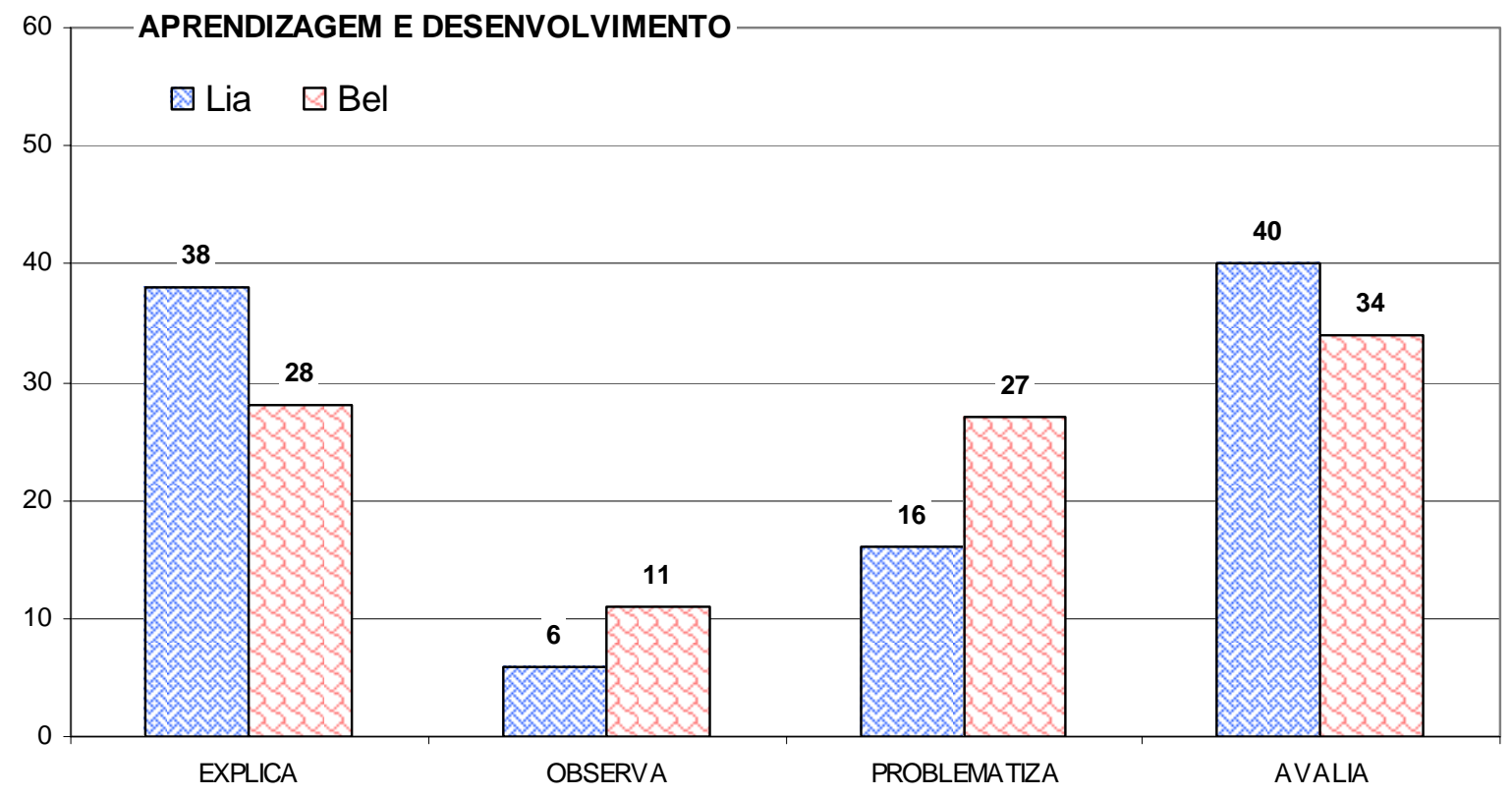

Figura 8 - Tema: "Avaliação da aprendizagem e do desenvolvimento" 